Rusistica

Latviensis

Глобальные и локальные процессы в славянских языках, литературах, культурах 2

Globālie un lokâlie procesi slávu valodās, literatūrā un kultūrā 2 
Latvijas Universitāte

Rusistikas centrs

\section{Rusistica Latviensis 8 \\ Глобальные и локальные процессы в славянских языках, литературах, культурах 2}

Globālie un lokālie procesi slāvu valodās, literatūrā un kultūrā 2 
Globālie un lokālie procesi slāvu valodās, literatūrā un kultūrā 2. Rīga: LU Akadēmiskais apgāds, 2019. - 182 lpp.

Recenzēts zinātnisku rakstu krājums no sērijas Rusistica Latviensis, izdošanai apstiprināts Latvijas Universitātes Humanitāro zinātṇu fakultātes domē 07.01.2019.

\section{Zinātniskā redkolēǵija}

Igors Koškins (Latvijas Universitāte), priekšsēdētājs

Ludmila Sproge (Latvijas Universitāte), priekšsēdētāja

Ausma Cimdiña (Latvijas Universitāte)

Marko Karatocolo (Marco Caratozzolo) (Bari Aldo Moro universitāte, Itālija)

Venta Kocere (Latvijas Universitātes Akadēmiskā bibliotēka)

Simona Koričankova (Simona Koryčánková) (Masarika Universitāte, Čehija)

Ol̦egs Korostel̦evs (Олег Коростелев) (Krievijas Zinātņu akadēmijas

Pasaules literatūras institūts, Krievija)

Rozanna Kurpniece (Latvijas Universitāte)

Janīna Kursite-Pakule (Latvijas Universitāte)

Iveta Narodovska (Latvijas Universitāte)

Natalja Šroma (Latvijas Universitāte)

Manfreds Šruba (Manfred Schruba) (Milānas Universitāte, Itālija)

Andrašs Zoltans (András Zoltán) (Etveša Lorānda Universitāte, Ungārija)

Atbildīgā par krājuma izdošanu: Iveta Narodovska

Krājuma redakcijā piedalījās:

Tatjana Barišņikova, Nadežda Kopoloveca, Ludmila Sproge

Anotāciju tulkojums un redakcija latviešu valodā - Iveta Narodovska

Anotāciju redakcija angḷu valodā - Margarita Spirida

Raksti, kas publicēti krājumā, ir recenzēti.

\section{Recenzenti:}

Anna Stankeviča (Daugavpils Universitātes profesore, Latvija)

Mikela Venditi (Michela Venditti) (Neapoles Universitātes "L'Orientale" profesore, Itālija)

ISBN 978-9934-18-407-9

(C) Latvijas Universitāte, 2019

DOI: http://doi.org/10.22364/ruslat.glp 
Гиобамьные и мокамьные процессы в славянских языках, митературах, кумьтурах 2. Рига: Изаательство Аатвийского университета, 2018. - С. 182.

Рецензированный сборник научных трудов из серии Rusistica Latviensis утвержАен к печати Аумой факумьтета гуманитарных наук Аатвийского университета от 07.01.2019.

\section{Научная реАкоммегия}

Игорь Кошкин (Аатвийский университет), преАсеАатель

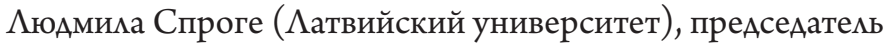

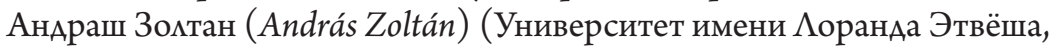
Венгрия)

Марко Каратоццоло (Marco Caratozzolo) (Университет Бари Альдо

Моро, Итамия)

Симона Коричанкова (Simona Koryčánková) (Университет Масарика, Чехия)

Олег Коростелев (Институт мировой митературы Российской академии наук, Россия)

Вента Коцере (Академическая библиотека Аатвийского университета)

Розанна Курпниейце (Аатвийский университет)

Янина Курсите-Пакуме (Аатвийский университет)

Ивета Народовска (Аатвийский университет)

Аусма ЦимАиня (Аатвийский университет)

Наталья Шром (Аатвийский университет)

МанфреА Шруба (Manfred Schruba) (Миланский университет, Италия)

Ответственная за издание сборника: Ивета Народовска

В редактировании сборника участвоваци:

\section{Татьяна Барышникова, НадежАа Копомовец, Мюдмима Спроге}

Перевод аннотаций на матышский язык и редактирование - Ивета Народовска

РеАактирование аннотаций на английском языке - Маргарита СпириАа

Труды, опубликованные в сборнике, прошли преАварительное рецензирование.

\section{Рецензенты:}

Анна Станкевича, профессор Ааугавпилсского университета, Аатвия Микела Вендитти (Michela Venditti), профессор Университета Неаполя $\Lambda$ 'Ориентале, Итация 


\section{Содержание}

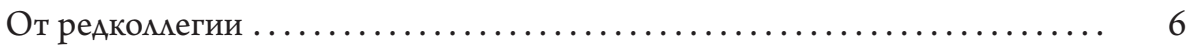

АИТЕРАТУРОВЕАЕНИЕ

\section{Наталья Вериинина}

«Рижский текст » в путевом очерке Ф.В. Булгарина

«ПоезАКа из АифмянАии в Самогитию, через КурмянАию, метом

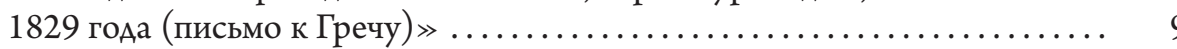

\section{Һюдмияа Спроге}

Из переписки Яниса Судрабкамна с Надеждой Павмович ............ 17

Татьлна Барьиникова, Ивета Народовска

Роман Ф.М. Аостоевского «ИАиот» в матышских переводах ......... 23

\section{Наталья Шром, Наталья Михаленко}

Утопия войны в русской и матышской митературе 1920-х годов ........ 31

\section{Элина Круповича}

Приходская жизнь Рижской церкви Всех Святых до 1914 года ......... 41

\section{Валентина Борбунюк}

«Сюжет Аля небольшого рассказа»: новемла И. Франко «Крыло

сойки» в контексте драматургии А. Чехова .................... 50

\section{Полина Поберезкина}

Ю. Балтрушайтис в печати Украины 1910-20-х гг. ................ 59

\section{Оксана Пашко}

Студент-филолог в Советской Украине 1920-х гг. (на материале записных книжек Сомомона Рейсера) $\ldots \ldots \ldots \ldots \ldots \ldots \ldots \ldots \ldots \ldots \ldots$

\section{Татьлна Тернова}

Творчество М.Ю. Аермонтова как объект рецепции в пьесе

А. Мариенгофа «РожАение поэта»

\section{Мариса Хорева}

Нарративные стратегии в новейшей

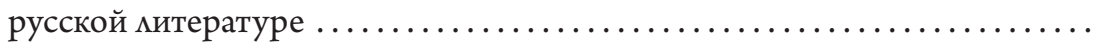

\section{Александр Житенев}

Будущее митературы как объект модемирования (на материале публикаций журнама Pastor) 


\section{Ирина Антанасиевич}

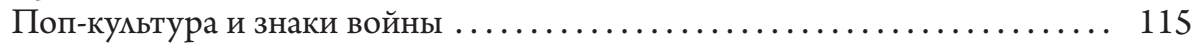

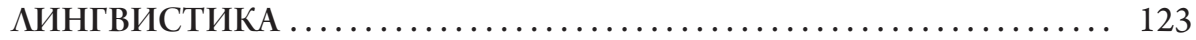

\section{Ольга Горицкал}

Русский язык в Беларуси и Аругих постсоветских странах: споры

о терминах

\section{Татьяна Савчук}

Семантико-прагматические ошибки в научной аргументации

(на материале русских и беморусских гуманитарных текстов) ......... 135

\section{Алесл Шевцова}

Белорусский рекламный Аискурс сквозь призму глобализационных

процессов: сопоставитемьный аспект ........................ 148

\section{Маргарита Хазанова}

Феминитивы в современном украинском языке: норма и узус глазами

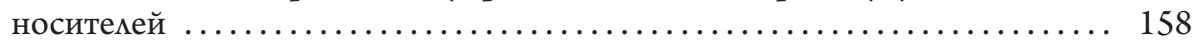

\section{Виталий Емельяненков}

Балетная терминология в славянских языках ................. 168

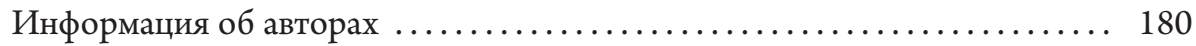




\section{От редколлегии}

Восьмой сборник серии Rusistica Latviensis в своей основе составлен из материалов, прочитанных в виде Аокладов на международной научной конференции «Глобальные и мокальные процессы в славянских языках, митературах, культурах 2», которая проходила 8-9 марта 2018 года, в рамках проекта «Гуманитарная мысль - язык, текст, кумьтура».

Тема, вынесенная в заглавие настоящего сборника, явно Аает понять то возросшее внимание, которое филологи уделяют продуктивности этой проблематики. Об этом свидетельствуют проблематика публикаций, преАставленных как рижанами, так и гостями конференции Т. Барышниковой и И. Народовской, А. Спроге, Н. Шром, (Рига, Аатвия) Н. Михаценко, М. Хазановой (Москва, Россия), Н. Вершининой (Псков, Россия), В. Бобронюк (Харьков, Украина), П. Поберезкиной, О. Пашко (Киев, Украина), О. Горицкой, Т. Савчук (Минск, Беларусь), А. Шевцовой (Магилёв, Беларусь), В. Емельянинкова (Аюблин, Польша). Материалы, посвященные интерпретации множественных тематических комплексов, можно кратко преАставить в слеАующем перечне, гАе отражены разные исследовательские сюжеты: специфика «рижского текста» в сочинении ФадАея Булгарина «ПоезАка из АифмянАии в Самогитию, через Курмянаию, летом 1829 года (Письмо к Гречу) ; поэтика новемлы Ивана Франко «Крыло сойки» (1905) в контексте Араматургии А.П. Чехова; обзор матышских переводов романа Ф.М. Аостоевского «ИАиот», сравнительный анализ переводных форматов (сокращение текста, мексические и фразеологические единицы, не имеющие полного эквивалента в матышском языке); утопические сюжеты о бескровном ведении войны в 1920-е гг., характерные темы Аля русских и матышских авторов, пишущих о вооруженном конфмикте с позиций прометеизма и сопутствующему этой концепции типу героя; поп-культура и знаки войны: проблема военного шеврона как маркера в опознавательной системе «свойчужой»; нарративные стратегии в новейшей русской митературе с упором на смену жанровых парадигм; интертекстуацьность в пьесе А. Мариенгофа «РожАение поэта», где осмысливается формирование творческой мичности Аермонтова; Юргис Балтрушайтис в печати Украины 1910-1920-х гг., его первые переводы на украинский язык и рецепция его творчества по материалам периодики и архивных фондов; эпистолярные материалы из неукомплектованного архива Н.А. Павлович, письма к ней Яниса Судрабкална; характеристика оппозиций «общего» и «локального» времени на материале публикаций, посвященных будущему в условиях постмодерна в концептуалистском журнале Pastor; эстетика аутсайдерства в современной Аетской митературе; неопубликованные материалы из наследия Соломона 
Рейсера о кумьтурной ситуации в Киеве 1020-х гг.; приходская жизнь Рижской церкви Всех Святых до 1914 г.; русская терминология в Беларуси и в Аругих постсоветских странах; семантико-прагматические ошибки в научной аргументации на материале русских и белорусских гуманитарных текстов; сопоставительный аспект белорусского рекламного Аискурса сквозь призму глобализационных процессов; феминитивы в современном украинском языке; балетная терминология в славянских языках.

ПреАлагая читателям статьи из очереАного сборника, реАкоммегия наАеется на продолжение давней и плодотворной традиции сотрудничества отделения Русистики и славистики факультета Гуманитарных наук Аатвийского университета с Аругими славянскими институциями Запада и Востока.

Редкомлегия 
ЛИТЕРАТУРОВЕДЕНИЕ 
DOI: http://doi.org/10.22364/ruslat.glp.01

Наталья Вершинина

\section{«Рижский текст» в путевом очерке Ф.В. Булгарина «Поездка из Лифляндии в Самогитию, через Курляндию, летом 1829 года (письмо к Гречу)»}

В статье рассматривается специфика «рижского текста» в малоисследованном сочинении Ф.В. Бумгарина «ПоезАка из АифмянАии в Самогитию, через КурмянАию, метом 1829 года (Письмо к Гречу)». Анализируется своеобразие «путевых заметок» писатемя как многофункционального жанрово-стилевого образования. Аелается вывод о наличии «механизма» (В. Топоров), способствующего выделению в «путешествии» Булгарина «рижского текста». На структурно-семантическом уровне в нем реализуется мысль писателя о благотворном воздействии просвещения на Ауховную и материальную стороны жизни «балтийской столицы».

Ключевые слова: Рига, «рижский текст», «литературное путешествие», читатель, культура повсеАневности, жанровая традиция

«ПоезАКа из АифмянАии в Самогитию, чрез КурлянАию, метом 1829 года (Письмо к Гречу) Ф ФаАлея Булгарина, напечатанная в четырех номерах газеты «Северная пчела» за 1829 гоА, Ао сих пор принадлежит к числу мамоисследованных. Представляется, что основанием может быть не только негативный отпечаток, который несет на себе репутация Бумгарина, можно преАположить, что причиной является и собственно митературный показатель: жанрово-стилевая «неопределенность» его «путешествий», их выпадение из принятой митературоведением типологии. Исследователи этой формы, в том числе и позАнейшие: В.А. Михайлов (Михайлов 1999), И.В. Банах (Банах 2004), Н.Ф. Иванова (Иванова 2010) - могли испытывать затруАнения относительно присоеАинения путевых заметок Булгарина к Авум известным разновианостям: географическому, «объективному», «ре-

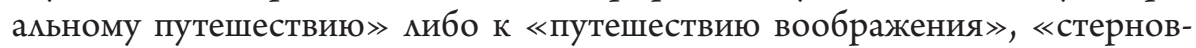
ской» ветви жанра, гАе «настоящего описания путешествия, в сущности, нет» (Роболи 1926: 48). И то и Аругое, по меркам традиционных митературоведческих классификаций, преАполагает элемент эстетизации, имеющий хоть и разный кумьтурный генезис, но одинаково значимый в плане поАхоАа к произведениям с позиций стилистики и поэтики.

Что касается путевых заметок Булгарина, то они словно бы демонстрирует отторжение от каких-либо требований эстетики. Термин «гибриАный» по отношению к Аанному жанру реализуется автором буквально 
(можно преАположить, не без огмядки на Н.М. Карамзина - автора «Писем русского путешественника») - как смешение разнородных стияевых и интонационных планов, описаний увиденного воочию и почерпнутого из книжных источников, статистических и историко-экономических сведений и пространных авторских отступлений, создающих «имАюзию $<\ldots>$ интимности» (Роболи 1926: 44).

Изучение структуры «литературных путешествий» Бумгарина свидетельствует об устойчивой устремленности автора не в сторону эстетики, а в область китературного быта. Очевидно, Булгарин ценил в «путешествиях», прежде всего, их коммуникативную, посредническую функцию. Это означало, что он, с одной стороны, приподымац публику наА привычной обыденностью, а, с Аругой - Аавац понять, что сознает условность расстояния межАу собой и ею и всегАа готов вступить во внелитературные отношения, касающиеся проблем существенных: материальных, политических, моральных и ряда Аругих.

В собственной кмассификации Булгарина путешествия входили в обмасть литературы - об этом свидетельствует его письмо А.Ф. Орлову от 13 апремя 1845 г.: «Ао сих пор написано мною и издано в свет, по части словесности: 16-ть томов романов, 18 томов повестей, статей о нравах, биографий, разных исторических отрывков и путешествий, один том путешествия в Швецию <...> (Видок Фиглярин 1998: 472). При этом писатель иегко переводия «путешествие» во внелитературный контекст, о чем свидетельствуют его «записки» в III отделение.

Так, в агентурной записке, скопированной управмяющим III отАемением М.Я. Фоком, условно озаглавленной «О поездке Булгарина в Остзейские губернии», задачи, побудившие автора к «путешествию», изможены в следующем порядке: «1) Отвесть больную жену к морским водам <..> 2) Окончить фамильные Аела $<\ldots>3$ ) Отдохнуть от трудов механических по журнаку и рассеяться $<\ldots>4$ ) Оживить описанием путешествия свои журналы» (Видок Фиглярин 1998: 170). Результатом этой поездки, наряду с Аругими ее слеАствиями, Аействительно стала пространная «Прогулка по


нее, публиковавшиеся в той же газете. Характеризуя этот текст, современный исследователь справеАливо отмечает Аанное в нем «историческое и этнографическое описание <...> региона» (Видок Фиглярин 1998: 170), что не отменяет общей установки Булгарина, цеми которого и здесь быми заведомо экиектичны, по-своему специфичны.

В русле нашей темы это означает, что возможно ввести в обихоА, применительно к «литературным путешествиям» Бумгарина, семиотическую категорию «текст»: как указывает В.Н. Топоров, говоря о Петербургском тексте, это «не просто усиливающее эффект зеркало города, но устройство, с помощью которого и совершается переход от реального к реальнейшему, пресуществление материальной реальности в Ауховные ценности», но при этом он «отчетливо сохраняет в себе следы своего внетекстового 
субстрата и в свою очередь требует от своего потребителя умения восстанавливать <...> связи с внеположенным тексту, внетекстовым Аля каждого узма Петербургского текста» (Топоров 1995: 259). Приведенное замечание касается не только Петербургского текста - как показывают исследования матвийских ученых, «рижский текст», в основание которого положена Рига, ее «образ и смысл» (Kursīte, Sproge, Cimdiña 2008: 8) содержит богатый и перспективный Аля Аальнейшего изучения материал.

Изначально Рига входила во внелитературный кругозор Булгарина - в 20-30-е годы он активно измагал в записках Аля III-го отАеления сужАения «о Аухе жителей Остзейских провинций и Аитвы» (ВиАок Фиглярин 1998: 178). По существу, зАесь выстраивался «первичный» «рижский текст», его «узАы», по выражению В.Н. Топорова. ОАновременно созАавался аналог митературного «рижского текста». Важнейшими «узмовыми» темами стали: гражданское общество, его состав и настроение разных слоев («чиновники и бюрократы», «высшие чиновники», «помещики», «часть жителей из купечества и Аворян»); состояние торговли (в том числе, книжной), правосуАия, просвещения; отношение к религии, госуАарю, российской госуАарственности (Видок Фиглярин 1998: 178-190).

Описание Риги, составмяющее не меньше половины материала, вошеАшего в его сочинение «ПоезАка из Аифмяндии в Самогитию, чрез Курмянаию, метом 1829 года (Письмо к Гречу) - это еще одна огласовка узнаваемых реалий, занимающих автора, увиденных словно бы с близкого расстояния, но при этом производящих «цельно-еАиное» (Топоров 1995: 261) впечатление сверхтекстовой структуры. «Рижский текст» оАновременно созАается и в соответствии с конкретным политическим и социально-экономическим содержанием момента (предмет внимания Булгарина), и с его неизменными универсальными составляющими, которые домжны вкАючить обозреваемый город не только в сферу общественных отношений, но и в историю существования человечества.

Представление Риги читателю начинается с конкретного эпизода - посещения путешественником «знаменитой» «Ивановской ярмарки, проАолжающейся три недели от Иванова Аня, т.е. от 24-го Июня». Рассказ вводит читателя в подробности обстановки этого Аейства: «В ограде кафеАрахьной церкви Аютеранского исповеАания (Dom), среАи города, устроены в несколько миний красивые балаганы, с Аовольно широкими перехоАами; кроме того, товары разложены по Алинным коридорам обширного зАания, бывшего некогАа Католическим монастырем, соеАиненного с церковью. Из ограды должно переходить в коридоры через самую церковь, которая всегАа отворена» (Булгарин 1829а). Аалее следует расширение «рижского текста» типичным Амя автора способом аналогий - как заметил Булгарин в Аругом своем путешествии: «Всё это может быmb, а гАе нет верного, там позволено Аогадываться и судить по аналогии» (Булгарин 1835). РассужАения путешественника не сухо публицистичны - скорее, они настраивают на тон душеполезной беседы: «Не вхожу в рассуждения 
прилично $и$ превращать храм божий в торжище, но помню, что Спаситель повелел удалиться торговцам за ограды храма иерусалимского, как то виАим из Евангелия. Это мысль родилась в голове моей в самом конце ярмарки, и я, осмотревшись кругом, вообразил, что на самом Аеле нахожусь в Иерусалиме».

Пиан авторских рассуждений, реализуемый во взаимодействии с наличной жизненной конкретикой, - принцип, межащий в основе организации «рижского текста», но у Булгарина «воображение» путешественника нереАко колеблет баланс объективного и субъективного: «Уиицы в городе Риге узкие и неправильные; Аомы высокие, никакой архитектуры; в кажАом почти доме мавка, а наА мавкою надпись или вывеска на Немецком и Еврейском языках; множество Евреев на улицах и в мавках, наконец, торжище возце храма и самый храм готический, необыкновенной высоты, - все это вместе сильно подействовало на мое воображение, которое перенесло меня в Аревность, на горы Сиона. Впрочем, все купеческие народы и города в Аревности и новые времена несколько похожи Аруг на Аруга. Аксиома: оАни причины произвоАят оАни послеАствия. Первая причина торговли выгода - послеАствия известны» (Булгарин 1829а).

Аанное замечание переводит бесеАу с читателем в новое русло - в план преАставлений о послеАствиях сугубо практических жизненных целей и понятий о выгоде не только Аля отАельного человека, но страны или города. «В торговых городах и народах обеА или бал входит в торговый баланс, и Аолжен принесть проценты; ссуда есть также роА оборота, который Аолжен Аоставить выгоды, хотя бы капитал пропац невозвратно. Привыкнув к расчету, человек делается сам машиною, и торговые города обыкновенно насемены подвижными счетами.

Музы никогаа не жили в Аружбе с Пиутусом и Меркурием. Тир и СиАон, а после Карфаген, славившиеся в Аревнем мире как первые торговые города, не произвели ни одного великого Писатемя и Художника».

Применяя эту закономерность к Риге, путешественник, следуя принятой могике, приходит к критической точке зрения: «Просвещенное Аворянство не мюбит жить в Риге, где належало бы состязаться с милмионщиками. Купеческая аристократия водится межАу собою чинно и церемониально. Чиновники знаются также межАу собою, и не имеют ни времени, ни средств предаваться наслаждениям. Все Авижение, вся жизнь в Риге есть впуск и выпуск товаров. Предмет разговоров: курс, цены и биржевые известия вообще. Есть исключения из правия, но их немного» (Бумгарин 1829a).

Несмотря на то, что набцюдения и выводы путешественника подаются читателю как его собственное, только что сделанное открытие, они «прочитываются» уже в границах «рижского текста», начамо которому было положено на рубеже XVIII-XIX веков (описания Риги Н. Крамзиным, Б. Пестелем (1798), О. Гуном (1804) и Ар.). Контуры «рижского текста», например, были намечены в работе Гуна «Топографическое описание 
города Риги с присовокуплением врачебных наблюдений». 3Аесь выделены опорные пункты «текста», которые позднее на свой каА «оживит» Букгарин. По поводу «отсутствия» писателей в Риге у Гуна, в частности, сказано: «ЗАесь не занимаются сочинением книг < ...>» (Гун 1804: 168).

Но у Гуна отсутствует риторика противопоставления Аруг Аругу словесности и торговми. У Букгарина этот прием, возможно, предполагает Авойной эффект: заостряющий уже указанный контраст и оАновременно позволяющий сказать, что Аалеко не чужАая путешественнику сфера практической деятельности, не рожАая гениев, способствует распространению просвещения в массах. Критическая аттестация, таким образом, обнаруживает внутри себя позитивную сторону. Закономерно преАположить: если задача бумгаринских путешествий не сводилась к сугубо митературной, то важнее Аля автора было показать, как просвещение влияет на повседневный быт, облагораживает его, рождает «пламенный патриотизм», воспитывая взамен «писателей» гуманных мюдей.

На свой маА следуя за Гуном, Булгарин созАает как бы «поверх» его сочинения свой «рижский текст». У Гуна: «< .. > в прочем однако ж Аостаточные Аюди знатного и среднего состояния, также знатные и просвещенные особы в городе почитают за честь иметь у себя библиотеки, в коих находятся Арагоценные собрания, касательно Иифмяндской истории и во-

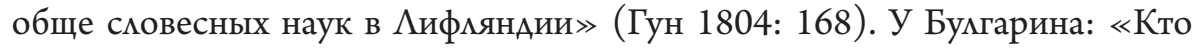
зАесь покупает Русские книги, которых и в самой России немного покупают? Чиновники Русские, офицеры, малое число Русских купцов и здешних Аворян, которые Аолго служили в России и привыкли к Русскому языку. Вообще Аворянство в Остзейских провинциях ныне весьма просвещенное, и если, по несчастию, большая часть не читает по-русски, то, по крайней мере, по переводам с Русского знает кучших наших Писателей. Случайно я познакомился с молодою девицею (фон Б... рг), которая из мюбви к Русскому языку изучилась оному, и читает все, что выходит у нас кучшего» (Букгарин 1829b).

Воспроизводя модель «рижского текста» с опорой на Гуна, Бумгарин перенимает и ее компоненты. Их составляют: умицы с присущей им теснотой и одновременно - опрятностью; полиция и ее радение порядку; благотворительные заведения, существующие на пожертвования граждан; наличие учебных заведений, в их чисме - университет; торговмя и соотносимый с этой областью комплекс экономических проблем; правосудие и «землеАельчество», Аоведенные, по мнению Букгарина, Ао «совершенства».

Вновь прибегая к риторическому ходу, путешественник заявмяет, что не будет описывать Ригу и тем самым привлекает внимание к объекту, вызывая реакцию читатемя и его правомерный вопрос - почему? «Я не стану описывать тебе, на этот раз, города Риги, существующего слишком 600 мет и знаменитого в Северной истории. ЗАесь весьма много Аревностей, Аостойных подробного описания; но Амя этого надобно более места, нежели сколько позволяют пределы письма с Аороги». Пробудив в читателе 
сожаление о несостоявшемся «путешествии», путешественник спешит развеять разочарование подробным рассказом о Риге:

«Местоположение города живописно со стороны обширной Авины. Большие корабли подходят с товарами к самому плавучему мосту, и, останавливаясь кормами по обеим сторонам оного, составмяют прелестнейшую в мире умицу на гибемьной стихии. ВиА с этого моста на город, на форштаты и в море - еАинственный. Аревний замок Иифмянаских Гермейстеров возвышается с своими башнями на берегу, и высокие шпицы готических храмов, возносящихся к небу из громады красных крышек, представцяют великолепное зрелище. С. Петербургский форштат, построенный вновь после сожжения оного, в 1812 году, есть почти особый город в новом вкусе, с широкими улицами и красивыми Аомами правильной архитектуры.

Нельзя Аовольно надивиться чистоте в городе Риге, при столь тесных улицах и Аомах без Аворов, или с такими Аворами, что еАва можно на них повернуться. Это Аолжно отнести столько же к чести Помиции, сколько и к опрятности жителей. Без больших и ежеАневных усилий почти невозможно было бы содержать в чистоте эту массу Аомов, построенных почти оАин на Аругом. Внутри еще чище, и хотя в убранстве Аомов нет такой роскоши, как в Петербурге, но чистота и прочность заменяют измишество, и мне горазАо более нравится.

$<\ldots>$ Ни в одном городе в целой Российской Империи, и вероятно ни в оАном в Европе, нет столько благотворительных заведений Аһя воспитания юношества, Аля призрения сирых и больных на счет города, как в Риге. Я имею описания сих заведений и исчисление сумм, пожертвованных городом и частными АюАьми на устройство и содержание оных. Великодушие купцов превосходит великое описание! < ..> В Риге возАвигнуты первые памятники Аля увековечивания славы, приобретенной Россией в Отечественную войну. Противу замка возАвигнута колонна с приличными надписями; в конце Петербургского форштата находятся прочные и красивые триумфальные ворота. <...> Все Аворяне и многие из купцов и среднего сословия служат Государю и Отечеству в военной и гражАанской службе, служат с честью и отлично. Большая часть из них прежАе кончат курс наук в Университете, или по крайней мере в высших учебных заведениях, и после уже поступают на службу».

Вывод сформулирован посредством аналогий, переходящих в перифраз: «Аерпт - есть Афины Аивонии, Рига - Карфаген Аивонского мира, Ревель - Спарта, Эстлянцы почти все воины по Ауху и воспитанию» (Булгарин 1829b).

В заключение отметим, что Булгарин, как бы межАу прочим, называет жанр своего сочинения - «письмо с дороги». Если эпистолярная форма, культивированная митературой XVIII века, была окружена эстетическим 
ореолом, что учитывалось автором, то прибавление «с Аороги» выводило ее из митературы в житейский план. На грани митературы и быта правомерно воспринимать и «митературные путешествия» Булгарина. Значение «рижского текста», преАставленного в разбираемом сочинении, не в Аостоверности - чтобы судить о ней (как это делает, путем анализа, А.Н. Николаевна Киселева относительно «Прогулки по Аивонии» Булгарина (Киселева 2006)), необходимо специальное исследование историко-краевеАческого характера. ВряА ми можно вести речь и об известных митературных Аостоинствах Аанного сочинения, исходя из того, что к белметризации путевых заметок не стремился и сам Булгарин. По нашему мнению, ценность Аанного сочинения - в закреплении уже имевшего место в труаах историков и митераторов образа Риги через свеАение воеАино опреАеляющих его бытовых и символических признаков. ПреАставление этих свойств как бы в Авойном освещении - сквозь присущую многим и принаАлежащую только путешественнику призмы созерцания действительности - формирует понятие «рижский текст», отвечающее запросам эпохи и ее преАставителей, среАи которых «привыкший к туризму» Булгарин (Рейтблат 2016: 399).

\section{Литература}

Банах, И.В. (2010). Нарративнал структура жанра путешествия (на материале русской митературы конца XVIII - первой трети XIX вв. Автореф. Аис. < ...> канА. филол. наук. Минск. 24 с.

Булгарин, Ф.В. (1829а). ПоезАка из Аифмяндии в Самогитию, чрез Курляндию, метом 1829 года (Письмо к Гречу). В: Северная пчела. № 103.

Букгарин, Ф.В. (1829b). Поездка из Аифмяндии в Самогитию, чрез Курмяндию, кетом 1829 года (Письмо к Гречу). В: Северная пчела. № 104.

Бумгарин, Ф.В. (1835). Путевые заметки на поезАке из Аерпта в Белоруссию и обратно, весною1835 года. В: Северная пчела. № 176.

Видок Финялрин. Письма и агентурные записки Ф.В. Булгарина в III отделение. (1998). Рейтблат, А.И. / Пубц., сост., предисл. и коммент. Москва: Новое китературное обозрение.

Гун, О. (1804). Топографическое описание города Риги с присовокуплением врачебных наблюдений. Ч. 1-2. Санкт-Петербург: Медицинская типография.

Иванова, Н.В. (2010). Жанр путевых записок в русской митературе первой трети XIX века (тематика, поэтика). Автореф. Аис. < .. > канА. филол. наук. Москва. 24 с.

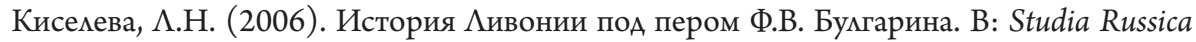
Helsingiensia et Tartuensia X: «Век нынешний и век минувший»: культурнал рефлексия прошедшей эпохи. В 2 ч. Тарту. Ч. 1. С. 114-127. Аоступен на 24.01.2016: http:// ruthenia.ru/document/541934.html

Михайлов, В.А. (1999). Эволючия жанра литературного путешествия в произведениях писателей XVIII-XIX веков. Автореф. Аис. <...> канА. филол. наук. Волгоград. 22 с.

Рейтблат, А.И. (2016). Переписка Н.И. Греча и Ф.В. Букгарина. В: Фаддей Венедиктович Булгарин: идеолог, журналист, консультант сыскной полиции. Статьи и материалы. Москва: Новое митературное обозрение. 632 с. 
Роболи, Т. (1926). Аитература «путешествий». В: Русская проза: Сборник статей. Эйхенбаум, Б., Тынянов, Ю. / реА. АенинграА: Academia. С. 42-73.

Топоров, В.Н. (1995). Петербург и «Петербургский текст русской митературы» (Введение в тему). В: Топоров, В.Н. Миф. Ритуал. Символ. Образ: Исследования в области мифопоэтического. Избранное. Москва: ИзАательская группа «Прогресс»-«Кумьтура». 624 с.

Kursìte, J., Sproge, L., Cimdina, A. (2008). Рига: образ и смысл. B: Rīgas teksts. Puжккий текст. Сборник научных материалов и статей. Рига: Latvijas Universitāte. 219 с.

\section{Rīgas teksts F. Bulgarina ceḷojuma aprakstā "Brauciens no Livonijas uz Samogitiju caur Kurzemi, 1829. gada vasara (vēstule Grečam)"}

Rakstā aplūkota Rīgas teksta specifika maz pētìtajā Fadeja Bulgarina ceļojuma aprakstā "Brauciens no Livonijas uz Samogitiju caur Kurzemi, 1829. gada vasara (vēstule Grečam)”. Raksta autore F. Bulgarina cel̦ojuma piezīmes pēta kā daudzfunkcionālu žanriski stilistisku veidojumu, atklājot Rīgas teksta producēšanas mehānismu (Vladimirs Toporovs). Rakstnieka ideja par apgaismības labvēlīgo ietekmi uz Baltijas galvaspilsètas materiālo dzīvi realizēta teksta struktūras un semantikas līmenī.

\section{The "Riga text" in "A trip from Liflandia to Samogitia, through Courland, in the summer of 1829 (The Letter to Grech)" by F.V. Bulgarin}

The article considers the specificity of the "Riga text" in the little-studied work "A trip from Liflandia to Samogitia, through Courland, in the summer of 1829 (The Letter to Grech)" by F.V. Bulgarin. The originality of the writer's "travel notes" is analysed as a multifunctional genre-style formation combining publicistic and literaryfiction components. about the research revealsthe existence of a "mechanism" that produces a movement from "the real to the real" (V. Toporov), which contributes to the application of the semiotic category "text" to the "travel" of Bulgarin. It is determined that the premises for the introduction of this work in scientific life are productive in terms of highlighting the "Riga text" in it, possessing the typical for the literary consciousness of the eighteenth and nineteenth centuries complex of features. The accentuation of the geopolitical, trade-economic, cultural and educational aspects of the "Riga text" expresses Bulgarin's idea of the beneficial influence of education on the spiritual and material life of the "Baltic capital" within the culture of everyday life, which occupies a priority place in the author's hierarchy of life values. 
DOI: http://doi.org/10.22364/ruslat.glp.02

\section{Людмила Спроге}

\section{Из переписки Яниса Судрабкална с Надеждой Павлович}

В статье впервые публикуются из архива Надежды Александровны Павлович (1895-1080) несколько корреспонденций: письма народного поэта Аатвии (1947) Яниса Судрабкална (1897-1975), Аатируемые 1945-м и 1960-ми годами прошлого века, а также - фрагменты из мемуаров русской поэтессы, где прослеживается история их знакомства и переводы на русский язык произведений матышского поэта.

Ключевые слова: Надежда Павлович, Янис Суарабкалн, Александр Блок, Янис Райнис, Мирдза Клява, А.С. Ерусалимчик, Рита Зелмане, Янис Калнберзинь, Борис Плюханов, Мария Киршгоф, матышские митераторы, переводы стихов

Письма из эпистолярного наследия Надежды Александровны Павлович (Пьяных 2005: 9-10), как правило, публиковались в связи с основной темой её воспоминаний - мичным знакомством в мае 1920 г. с А.А. Блоком, встречами и бесеАами с ним в 1920-1921-х гг. и послеАующим осмыслением судьбоносности этих событий в жизни поэтессы, переводчицы и мемуаристки (Гончарова 2011: 276-308). История знакомства и творческих взаимоотношений Павцович с матышским поэтом Янисом Судрабкалном (настоящее имя Арвидс Пейне: Arvīds Peine. См.: Kalniņa 2003: 569-570) практически не рассматривалась, хотя в мемуаре «Невод памяти» есть эпизод о Аетстве поэтессы и о «мальчике из Яунпиебацги»:

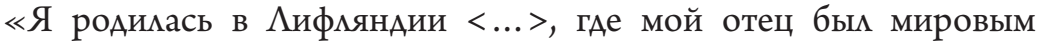
судьей. КогАа мне бымо Ава года, его перевели в Старо-Пебалгу [Вецпиебалгу. - А. С.], и там прошло мое Аетство Ао Аевяти мет. <...> Быи там огромный графский Аворец с прекрасным парком и флигель Аля гостей, который мой отец арендовал у графа. <...> В стороне $е$ ежал поселок, в нем - корчма. У корчмаря бывац мальчик из Яунпиебалги, чуть старше меня [позже народный поэт Аатвии - Ян Суарабкалн. $-\Lambda$. С.]. Мы с ним в Аетстве не играли вместе: с Аеревенскими

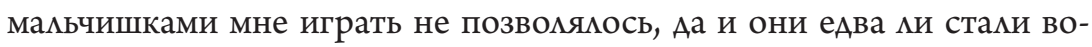
Аиться с русской чиновничьей Аевочкой. Уже пожилыми АюАьми, мы по телефону познакомились в Москве. В 1946-1947 годах в Риге мы встретились с Суарабкалном. Передо мной встал высокий застенчивый человек с Аоброй улыбкой. Мы говорили о Пебалге, о Аетстве. Он вспомниц толстую Аевочку, с большим бантом на голове, 
смотревшую сквозь решетку саАа, когАа он с Аругими Аеревенскими мальчишками прибегал, или вернее пробегал через Шереметевское имение. В 1948 г. мы с Суарабкалном вместе редактировали перевоАы Замаховской ${ }^{1}$ стихов Райниса. Я переводика стихи Судрабкална ${ }^{2}$. Аатышский язык я немного знала в детстве: няня у меня быма матышка, но потом я его забыла. А тут я стала что-то понимать, слыша разговоры на улицах, и почти инстинктивно разбираться в поАстрочниках, которыми я пользовалась при переводе. Так, я часто мовила ошибки в них, но исправить не могла. Не нужно мне было и метрической схемы поАлинника, уАарения ставила я правильно. Это облегчало мне работу наА переводами матышских поэтов. Я перевоАила Райниса (“Ave sol!”) 3 , Ванага ${ }^{4}, \Lambda$ мса ${ }^{5}$, Аинере ${ }^{6}$, Кемпе $^{7}$, но мегче Аругих мне было переводить именно стихи Суарабкална. Я всем своим существом ощущала подтекст стиха СуАрабкална, знаца то небо, траву, пейзаж, о котором он говориц. Сам Судрабкамн поражац скрытой грустью и скромностью. Волнуясь, он иногАа заикался, и я всегда радовалась, когда он преставац заикаться. Значит, сейчас ему спокойно и хорошо. Поэт свобоАно говорил по-русски, знац русскую митературу и поэзию, мюбим Блока ${ }^{8}$ Это меня сближало с ним. ПослеАний раз мы виделись с ним в Аоме творчества в Аубулты, я застала

1 М. Замаховская - переводчица народного матышского поэта Райниса, в Большой серии Библиотеки поэта есть ее переводы (Райнис 1981: 530-541).

2 Н. Павлович перевела следующие стихи матышского поэта: «Стужа», « Аатвии», «Ромену Ромлану в день шестидесятилетия» (Янис Судрабкалн 1984: 337-344).

3 Перевод поэмы Райниса на русский язык вышел в Риге в 1951 г. В фонде Павлович (Ф. 578) сохранился отзыв о переводе Б.В. Плюханова с эпизодами воспоминаний (неожиданной встрече на улице Риги с Я. Райнисом в 1927 г.). Отзыв быи направмен в «Иитературную газету» и подписан так: «Б. Пиюханов. Рига, ук. Я. Асара А. 14. кв. 9. Пиюханов, Борис ВАадимирович муж - Марии Сергеевны Киршгоф Аочери Авоюродной сестры Блока - Марианны Петровны, урожА. Блок». Переводчице поэмы Райниса, Н.А. Павлович, из отАела национальных митератур газеты было отослано письмо от 4 апреля 1951 г.: «Уважаемая НадежАа Александровна! РеАакция “Аитературной газеты” получила отзыв одного из читателей о Вашем переводе поэмы Райниса. К сожалению, мы так стеснены местом, что опубликовать его не преАставцяется возможным. Но я Аумаю, Вам будет приятно прочитать его. С приветом И. Боброва».

Jūlijs Vanags (1903-1986) - матышский писатель.

Valdis Lukss (1905-1985) - матышский поэт.

Cecīlija Dinere (1919-1996) - матышская писательница.

Mirdza Kempe (1907-1974) - матышская поэтесса.

8 Суарабкалн откликнулся на смерть Блока стихотворным циклом «Памяти Александра Блока», опубликованным в 1921-ом г., он же быц и первым автором статьи на русском языке «Блок в матышской митературе» (Сегодня 1926, № 267. 26 ноября), а также - многих публикаций в матышских и русских изАаниях о творческом наследии Александра Блока. Павлович в августе 1921 г. написала поэтическую эпитафию «Александр Блок» («Вот он в гробу, в георгинах и розах... ») 
У него молодых работников кино, пришеАших по Аелу, но все-таки нам УАалось немного поговорить и вспомнить прогулки по взморью, откос железной Аороги поА Асари, гАе мы Аолго бывали, говорили о “подвигах, славе" , о вопросах совести ... АрвиА Карнович всегАа был человеком совести и живого участия к мюАям, человеческой нужАе. Я помню, как ему как-то рассказали о туберкулезной Аевушке из беАной семьи. И он торопливо ответил: “У меня еще что-то осталось на сберкнижке. НаАо взять все, что осталось”. < .. > А потом - быц темноватый зац, цветы на полу, венок у гроба - и тишина, и горестно и

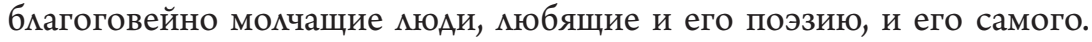
Мир его памяти! Аля меня АрвиА Карлович - Ян Судрабкамн - был

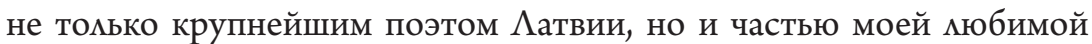
Пебалги, Аетства незабываемого. Пебалги я обязана истоками своего творчества. ЗАесь все было не только необыкновенно красиво и живописно, но и овеяно народными мегендами и историческими воспоминаниями» (Павлович 1978: 61-62).

С воспоминаниями Павлович тесно связан ее цикл, состоящий из 16-ти стихотворений, «Моя Аатвия», где начальный текст корреспондирует с приведенным мемуарным абзацем:

ЗАесь впервые трава, мне, ребенку, сказала:

$$
\text { «Зеленый», }
$$

Синева мне сказала: «Смотри, это цвет голубой!»

ЗАесь впервые стихи я услышала слухом вцюбленным.

Стала радость - страданьем, а песня - моею суАьбой.

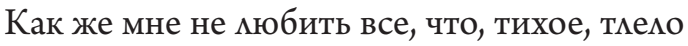
ПОА спУАОМ

Несказанною памятью детства! Его пронесешь

Ао могилы и в гроб, как впервые блеснувшее чуао,

И себя, может быть, только в этих глубинах Найдешь. (Павлович 1977: 209)

«ГАубины» памяти способствовали возврату к «брегу юности» и осмыслению своей судьбы во вновь обретенном пространстве, гАе «к востоку накрененные Аеревья, высокой Аюны шелковый песок... » и - обращение к Аругу Аетства и зрелых мет, как бы возрожАающим в Ане сегоАняшнем

9 Усеченная цитата из стихотворения А. Блока «О доблестях, о подвигах, о славе» (1908). 
Аамекое начало жизненного пути: «Аай руку, Аруг! Взгляни, матвийский клевер // Опять зарей цветет у наших ног» (Павлович 1977: 214).

Письмо и открытки Яниса Суарабкална хранятся в Рукописном отделе ИРАИ (Пушкинский Аом) в фонде Н.А. Павлович (Ф. 578). Приношу благодарность заведующей РО Т.С. Царьковой за возможность ознакомления с материалами пока полностью не обработанного фонда Павлович.

I

Т.<оварищ> Григулис ${ }^{10}$ уверяет, она занесла Ваши стихи в ССП ${ }^{11}$ т.<оварищ> Ерусамимчик ${ }^{12}$. Было бы ужасно, если стихи затерялись бы. Уехам я из Москвы, по своей мени и косности, не ответив на Ваше чудесное письмо и не поблагодарив за удовольствие, которое мне Аоставили Ваши прекрасные стихи, и не поблагодария я Вас, как слеАует, также за замечательные переводы моих стихов ${ }^{13}$. Аолг за мной страшный, и я не могу и сейчас еще погасить его, так как слишком позАно узнац, что товарищ еАет в Москву. Но, Ааю слово, в ближайшем будущем напишу Вам большое письмо. Может быть<,> и Вы черкнете мне несколько слов?

Пусть 1945 гоА принесет Вам много счастья, т.<оварищ> Павлович!

\section{С совершенным уважением}

Я. Суарабкамнс.

Рига,

15. 1.1945.

II

ГАубокоуважаемая,

Аорогая

Надежда Александровна,

Поздравляю Вас с Новым годом и желаю от всего сердца крепкого зАоровья, много новых чудесных стихов, много разных раАостей.

Ваш

Ян Суарабкамн

Рига,

3 января 1964 года.

10 Речь идет о жене известного поэта и митературовеАа Арвида Григулиса (Arvīds Grigulis, 1906-1989) писательницы Мирдзы Кляве (Mirdza Klava), в то время стуАентки химического и биологического факультета ПеАагогического института.

11 Союз советских писатемей.

12 Ерусалимчик Аия Степановна, митературовеА, критик, работала в ССП.

13 Переводы Надеждой Павлович стихов СуАрабкална опубликованы мишь частично. См. сноску 2. 
III

$\underline{\text { ABИA }}$

Рига,

1 мая 1964 года.

Аорогая НадежАа Александровна, спасибо и еще и еще раз спасибо за чудесную книжку стихов ${ }^{14}$, за богатейшие, мудрые и добрые письма, но сможете ми сохранить всю свою доброту ко мне после всех моих нехороших дел, забывчивости, жестокости? Ж е $\Lambda$ а ю зАоровья, новых стихов, разных радостей. Ваш Ян Судрабкалн.

IV.

Аорогая Надежда Александровна,

От всего серАца позАравляю с чудесным женским днем. Женская умыбка, Аюбовь, мудрость, нежность, храбрость побеАят, уничтожат все змое во всем мире.

С глубокой благодарностью и уважением Ваш Ян Судрабкалн.

Рига, 5 марта 1969 года.

$\mathrm{V}^{15}$

$<2>\ldots$ всего этого, а у меня в уме, Ауше, серАце остались мишь жалкие крохи мыслей и чувств. И оперу, и концерты, и театры, и кино посещаю крайне редко, но Риту Зелмане ${ }^{16}$ слышал и согласен с Вашей высокой оценкой ее голоса, мастерства, таланта. Может быть<,> мне удастся и поговорить и с товарищем Калнберзиным ${ }^{17},<3>$ пообещать твердо не могу. ВАияние у меня в верхах вообще ничтожно, почти никакого, Аа я и не стою уже тверАо в митературе, ошибки у меня, проступки, согрешения и мелкие и серьезные сыплются, как из рога обилия, со скоростью я совсем сошел с верного пути. И цена мне - грош.

Поздравмяю Вас, дорогая Надежда Александровна, с великим Праздником Победы и пожелаю Вам ещё много, много мет и радостей.

Ваш Ян Суарабкалн.

14 Вероятно, речь идет о первом изАании книги Н. Павлович «Аумы и воспоминания» (1962).

15 Начало письма, написанного на открытках в конце 1960-х гг., утеряно. Остались Аве открытки, пронумерованные Судрабкалном $-\langle 2\rangle,\langle 3\rangle$.

16 Рита Зелмане (Пориня, 1934) - легендарная певица (сопрано), с 1963 г. - солистка, более сорока мет проработавшая в $А$ атвийском театре оперы и балета.

17 Jānis Kalnbērziņš (1893-1986) - в 1940-е гг. Первый секретарь ЦК компартии Аатвийской ССР, с 1959-1970-е гг. ПреАсеАатель Верховного Совета $\Lambda$ ССР. 


\section{Список литературы}

Гончарова, Е.И. (2011). «Запомнить всё, отметить и сберечь ... » (НадежАа Павлович об Александре Блоке). В: Блок, А. Исследования и материалы. С-Петербург: изАательство «Пушкинский Аом». С. 276-310.

Павцович, Н.А. (1977). Сквозь долгие года... Избранные стихи. М.: ХуАожественная митература.

Павиович, Н.А. (1978). Аетство «ЯАан». Воспоминания. Ааугава (Рига). № 1. С. $60-72$.

Пьяных, М.Ф. (2005). Павлович. В: Русская митература XX века. Прозаики, поэты, драматурги. Биобиблиографический словарь. Т. 3. С-Пбг.: Олма - Пресс Инвест. C. 9-10.

Райнис, Я. (1981). Избранные произведения. Библиотека поэта. Большая серия. А.: Советский писатель.

Судрабкамн, Я. (1984). Стихотворения. Миниатюры. Перевод с матышского. М.: Художественная митература.

Kalniņa, I. (2003). Sudrabkalns Jānis. B: Latviešu rakstniecība biogräfijās. R.: Zinātne.

\section{Jāṇa Sudrabkalna un Nadeždas Pavlovičas sarakste}

Rakstā pirmo reizi publicēta korespondence no Nadeždas Pavlovičas (1895-1980) arhīva: Latvijas Tautas dzejnieka (1947) Jāņa Sudrabkalna (1897-1975) vēstules, kas datētas ar 1945. un 1960. gadu, kā arī krievu dzejnieces memuāru fragmenti, kuros aprakstīta viņas iepazīšanās ar latviešu dzejnieku, un fragmenti, kur runāts par J. Sudrabkalna dzejas tulkojumiem krievu valodā.

\section{The correspondence of Nadezhda Pavlovich and Jānis Sudrabkalns}

The correspondence from Nadezhda Pavlovich's archives of 1895-1980 is published for the first time and includes the letters of Latvian National poet (1947) Jānis Sudrabkalns (1897-1975) dated 1945 and 1960 as well as the excerpts from Nadezhda Pavlovich's memoirs describing their first encounter and Russian translations of Jānis Sudrabkalns' poems. 
DOI: http://doi.org/10.22364/ruslat.glp.03

\section{Татьяна Барышникова, Ивета Народовска}

\section{Роман Ф.М. Достоевского «Идиот» в латышских переводах}

Статья посвящена обзору матышских переводов романа Ф.М. Аостоевского «ИАиот». Авторы статьи рассматривают и в сравнительном аспекте анализируют три перевода романа Аостоевского - выполненные А. Межсетом (1926), 3. Мауриней (1936-1938) и Я. Меденисом (1961). При сравнительном анализе уделяется внимание стратегиям и проблемам художественного перевода (сокращение текста; мексические и фразеологические еАиницы, не имеющие полного эквивалента в матышском языке и Ар.). В статье Ааны краткие биографические справки о переводчиках, а также преАставлены сведения об изАательствах, публиковавших роман «ИАиот» в матышском переводе.

Ключевые слова: русско-латышские митературные связи, рецепция, художественный перевоА, стратегии перевода, Ф.М. Аостоевский

Роман «ИАиот» является оАним из часто изАаваемых на матышском языке произведений Ф.М. Аостоевского. С 1929 по 2015 гоА роман публиковался семь раз - АважАы в составе собраний сочинений и пять раз выхоАиц отАецьным изАанием. За это время текст романа переводился трижАы, что объясняется размичными причинами, в том числе внелитературного характера.

Впервые на матышском языке «ИАиот» вышем в 1929 году в изАательстве Grāmatu Draugs. Изаательство было основано в 1926 году, работало в Риге вплоть до 1944 гоАа, а затем Продолжило свою Аеятельность в Германии и США. Целью изАательства было сАелать книги Аоступными Аля широкого круга читатемей. Аля этого использовацась особая система распространения - книги не продавались в магазинах, а непосредственно доставлялись заказчику: в Риге и Аиепае на Аом, в Аругие регионах Аатвии - по почте. За упаковку и Аоставку книг нужно было платить только оАин мат. ИзАатели стремились УАовлетворить запросы разных групп читателей. Выпускались не только книги матышских авторов, но также классические и современные произведения зарубежной митературы, детская митература, криминальные романы, описания путешествий, научно-попумярные и энциклопеАические справочники по истории, зоологии, географии, медицине, истории музыки и искусства. Роман «ИАиот» был опубликован в шестьАесят Аевятом томе серии Vērtīgo grāmatu virkne. На матышский язык роман перевёл писатель и книгоиздатель Аугустс Межсетс (1890-1977), работавший в изАательстве Grāmatu Draugs как корректор и переводчик. А. Межсетс уже обращался к 
творчеству Ф.М. Аостоевского: в 1927 году он перевёл «Записки из мёртвого Аома» Аля изАательства Ran,kis. Очевидно, что, работая наА переводом романа «ИАиот», А. Межсетс учитывам тип издания, ориентированного на массового читателя, возможно, впервые открывавшего Аля себя творчество русского писателя. Этим объясняется дополнение концептуального названия номинативным, при этом авторское название приведено в скобках Knazs Miškins (Idiots). Текст романа подвергается значительным сокращениям: он занимает всего Авести Аевять страниц небольшого формата.

В 1930-ых годах издательство Grāmatu Draugs начало выпуск многотомных изАаний. Выходят собрания сочинений К. Гамсуна, В. Пкудониса и Аругих скандинавских и матышских авторов, а в 1936-1938 годах - собрание сочинений Ф.М. Аостоевского в шестнадцати томах. Роман «ИАиот» помещён в оАиннадцатом и в Авенадцатом томе. Поскольку такого рода изАание преАполагало публикацию полного текста оригинаца, был выполнен новый перевоА, оАнако установить имя переводчика оказалось непросто, так как в библиографических описаниях оно не указано. При работе с изданием выяснилось, что имя переводчика тщательно зачёркнуто карандашом, мишь на оборотной стороне титульного Аиста от руки мелким почерком сАелана приписка: No krievu valodas tulkoja Zenta Maurina. Это объяснило отсутствие сведений о переводчике: имя Зенты Маурини (1898-1978), известной матышской писательницы и филолога, оказавшейся после 1944 года в эмиграции, преподававшей в университетах Германии, Швеции, Швейцарии и Италии и получившей множество почётных награА, в Советской Аатвии упоминать было запрещено. Обращение к творчеству Ф.М. Аостоевского не было Аля Зенты Маурини случайностью. Она является автором неоднократно изАанной монографии Dostojevskis, vina personība, mūžs un pasaules uzskats. Третье изАание этой книги вышло также в изАательстве Grāmatu Draugs в 1936 году.

Несмотря на то, что перевод 3. Маурини достаточно бцизок к оригинацу, в советское время он не мог использоваться по идеологическим причинам, поэтому Аля изАания, подготовленного Аатвийским государственным издательством в 1961 году, был выполнен новый перевод. Его автор - матышский поэт и переводчик Янис Меденис (1903-1961). Как и 3. Мауриня, после прихода Советской армии в 1944 году, он намеревался эмигрировать вместе с семьёй, но задержался в Курземе и в 1946 году быц арестован, обвинён в антисоветской Аеятельности и осуждён на Аесять мет. Срок отбывал в магерях Норильска, Иркутска и в Астрахани. В 1955 году после амнистии вернулся в Аатвию. Стихотворения Я. МеАениса мибо не печатались, мибо подвергались цензуре, потому он занимался переводами. Переводиц произведения М.Ю. Аермонтова, А.И. Куприна, а также Ф.М. Аостоевского. Кроме романа «ИАиот» им были переведены «Братья Карамазовы» и «Униженные и оскорбленные». Перевод романа «ИАиот», выполненный Янисом Меденисом, максимально приближенный к оригиналу, считается классическим и воспроизводится во всех последующих изАаниях, в 
частности в собрании сочинений Ф.М. Аостоевского, выходившем в издательстве Liesma с 1973 по 1978 гоА, а также в послеАнем изАании 2015 года.

Судя по биографическим Аанным, все переводчики Аостаточно хорошо владели русским языком, что позволило им Аовольно точно передать текст оригинала. ОАнако в некоторых случаях, перевод вызвал значительные затруанения. Учитывая объём статьи, мы ограничились сопоставлением переводов пяти первых глав первой части романа, однако выявленные примеры представцяются весьма показательными.

Наибольшие трудности вызывает перевод мексических и фразеологических еАиниц, не имеющих полного эквивалента в матышском языке. ПрежАе всего, это относится к переводу слова юродивый, которое является ключевым в романе, так как неоднократно используется как среАство номинации главного героя - князя Мышкина. Как известно, юродство в русской культуре и в русском языковом сознании осмысляется как оАно из проявлений святости, Юродивый - чемовек, отвергший все мирские ценности и веАущий аскетический образ жизни, обладающий мудростью, которая не сразу осознаётся окружающими и воспринимается как безумие, нарушение общепринятых норм поведения (Панченко 1999: 392-407). В матышской кумьтуре феномен юродства не был распространён, поэтому соответствующий мексический эквивалент в матышском языке отсутствует. Переводчики пытаются найти соответствующую замену: А. Межсетс и 3. Мауриня вместо слова юродивый используют plānprātinš̌ ${ }^{1}$ (Dostojevskis 1929: 15; Dostojevskis 1936-1938: 18), Я. Меденис - vientiesitis² (Dostojevskis 1975: 17), что ближе к значению Аанного слова в оригинале. ОАнако добиться полной эквиваментности ни оАному из переводчиков не уАаётся, так как утрачивается семантический признак «святость», что приводит к потере значимой эстетической информации, так как снимается амбивалентность образа главного героя.

Также трудности возникают при переводе слов, обозначающих опредемённые реалии материальной и духовной сферы русской культуры, которые могут быть не знакомы матышскому читателю. КажАый из переводчиков выбирает Аля их передачи размичные стратегии. Например, конструкцию Четьи-Минеи читает (Аостоевский 1973: 10). А Межсетс вовсе опускает, чтобы не усложнять восприятие текста романа матышскому читателю, возможно, не знакомому с традиционной православной культурой. Аругие переводчики используют лексемы с более общим значением: 3. Мауриня переводит Аанную конструкцию как svètos rakstus lasa ${ }^{3}$ (Dostojevskis 1936-1938: 13), а Я. Меденис - как svēto grāmatu lasa ${ }^{4}$ (Dostojevskis 1975: 13). Несмотря на то, что оба перевода не совсем точны, такая замена преАставцяется

Аурачок, слабоумный.

Наивный, Аоверчивый человек, простачок.

3 Святое писание читает.

4 Святую книгу читает. 
оправданной с точки зрения прагматики перевода и не искажает смысл оригинала. Слово тулуп сохранено во всех переводах, но передаётся по-разному. А. Межсетс стремится подчеркнуть национальный колорит и перевоАит в тулупе как krievu $k a z ̌ o k \bar{a}^{5}$ (Dostojevskis 1929: 10), 3. Мауриня использует уменьшительную форму puskažocin, $\bar{a}^{6}$ (Dostojevskis 1936-1938: 13), а Янис Меденис - стилистически нейтральное и наиболее точное $k a z ̌ o k \bar{a}^{7}$ (Dostojevskis 1975: 13).

ОАна из сложных проблем при мюбом переводе - переАача фразеологизмов, имеющихся в оригинальном тексте. Анализ переводов показал, что переводчикам не всегАа удаётся найти верное решение. Так при переводе фразеологизма языком колотить Я. Меденису удалось найти близкие соответствия во фразеологии матышского языка mēli trìt (Dostojevskis 1975: 13). 3. Мауриня использует сочетание kustinät mēli (Dostojevskis 1936-1938: 13), не совсем точно передающее исходное значение. А. Межсетс заменяет фразеологизм глаголом paplāpät ${ }^{8}$ (Dostojevskis 1929: 11), что не позволяет переводчику сохранить экспрессию подиинника. При переводе фразеологизм не тебе чета ни одному из переводчиков не уАахось найти эквивалентную замену:

«Это, говорит, не тебе чета, это, говорит, княгиня, а зовут ее Настасьей Филипповной, фамилией Барашкова» (Аостоевский 1973: 11).

Tā, viņš saka, nav tavam zobam (Dostojevskis 1929: 12).

Tā, saka, tev neder, tā, saka, ir knaziene, un vinu sauc Nastasja Fiļipovna, uzvārds - Baraškova (Dostojevskis 1936-1938: 15).

$\check{S}_{\bar{i}}$, viņš saka, neesot man piemērota, vina esot knaziene, un saucot vinu par Nastasju Fiļipovnu, uzvārdā par Baraškovu (Dostojevskis 1975: 15).

3. Мауриня вместо Аанного фразеологизма использует глагол neder ${ }^{9}$, Я. Меденис - конструкиию пеesot man piemérota ${ }^{10}$, а А. Межсетс использует при переводе фразеологизм nav tavam zobam ${ }^{11}$, в результате значение исходного фразеологизма передано неточно. ИногАа имеющийся в оригинале фразеологизм не известен переводчикам, что приводит к курьёзным ошибкам. При переводе фразеологизма кондрашка пришиб, только Я. Меденис

\footnotetext{
В русской шубе.

В полушубке.

В шубе, в тулупе.

Поболтать.

Не годится.

10 Не мне предназначена.

11 Не по твоим зубам.
} 
использовал матышский аналог trieka piebeigusi ${ }^{12}$, отмичающийся мишь нейтральной стилистической окраской:

«<..> с одним узелком от родителя во Псков убег, к тетке; Аа в горячке там и слег, а он без меня и помре. Конарашка пришиб» (Аостоевский 1973: 10).

$<\ldots>$ ar sainiti vien no tēva uz Pleskavu aizbēgu, pie krustmātes; ar drudzi tur nolikos gultā, bet viņš bez manis n,ēmis un nomiris. Trieka piebeigusi (Dostojevskis 1975: 12).

3. Мауриня, вероятно, не сумев найти соответствия в матышском языке, Аанный фразеологизм опускает, переАаётся мишь информация о произошеАшем событии - смерти отца Рогожина:

$<\ldots>$ ar vienu sainīti no sava tēva uz Pskovu aizbēgu, pie krustmātes, tur drudzis mani pārvarēja, bet viņ̌̌ - bez manis nomira (Dostojevskis 19361938: 13).

А. Межсетс, которому, Аанный фразеологизм, судя по переводу, не был известен, переводит его буквально, что приводит к неверной интерпретации всего преАложения: Рогожина побия некий КонАрашка, после чего Рогожин промежац в жару несколько Аней:

$<\ldots>$ aizbēgu no tèva uz Pleskavu pie krustmātes; tur saslimu ar karstuma gul̦u, bet tēvs nomira bez manas klātbūtnes. Kondraška mani piekāva (Dostojevskis 1929: 10).

Если говорить о переводах в целом, то самым точным и близким к оригиналу, безусловно, явмяется перевод Я. Медениса. Имеются мишь незначительные расхожАения, обусловленные языковыми размичиями или особен-

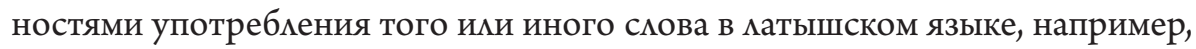
Я. Меденис, как и Аругие переводчики, переводит слово тётка как крёстная мать. Такая замена типична Аля матышского языка, так как слова tante и krustmāte часто используются как синонимы. ОАнако во всём рассмотренном фрагменте перевода прослеживается установка неукоснительно слеАовать тексту романа. Этого же принципа в основном придерживается также 3. Мауриня. Примечательно, что в её переводе встречаются случаи Авух вариантов перевода одного и того же топонима - Псков переводится то как Pleskava, то как Pskovs, что, вероятно отражает колебания в разговорной речи жителей Аатвии того времени.

Что касается перевода А. Межсетса, то, как уже отмечалось, главной целью переводчика была аАаптация текста романа Аля массового читателя, поэтому текст оригинаца подвергается существенным сокращениям. В большинстве случаев эти сокращения прагматически оправданы. В

12 Парамич разбил. 
частности, из описаний быми искмючены топографические подробности, которые могли быть неизвестны матышскому читателю, и некоторые второстепенные Аетали. В результате развёрнутое описание сокращалось Ао оАного преАложения, содержащего мишь фактическую информацию, как, например, в Аанном фрагменте:

«Скоро шумная ватага уАамимась по направлению к Вознесенскому проспекту. Князю надо было повернуть к Аитейной. Было сыро и мокро; князь расспросии прохожих, - Ао конца преАстоявшего ему пути выходимо версты три, и он решился взять извозчика» (Аостоевский 1973: 14).

Lìdz kñaza cel̦a mērķim bija verstes trīs ko iet, un viņš nolēma nobraukt turp važonī (Dostojevskis 1929: 15).

3. Маурияня и Я. Меденис при переводе этого фрагмента строго слеАуют оригинацу. А. Межсетс, напротив, сокращает не только описания, но и характеристики Аействующих миц. Например, опускаются имена и Аругие сведения о второстепенных персонажах, которые, по мнению переводчика, не играют важной роли в развитии сюжета. Так отсутствует упоминание о матери и сестре Гани, сообщается мишь, что Настасья Филипповна слышала много хорошего о его семье. Сокращена характеристика самого Гани: viņs esot energoisks cilvēks, lepns karjerists ${ }^{13}$ (Dostojevskis 1929: 42-43), что вносит немотивированные изменения в трактовку героя, акцентируя его негативные черты:

«Она слышала, что он человек с энергией, с гордостью, хочет карьеры, хочет пробиться. Слышала тоже, что Нина Александровна Иволгина, мать Гаврилы АрАалионовича, превосходная и в высшей степени уважаемая женщина; что сестра его, Варвара Ардалионовна, очень замечательная и энергичная Аевушка; она много слышала о ней от Птицына» (Аостоевский 1973: 42).

Viņa esot dzirdējusi, ka viņš esot enerợisks cilvēks, lepns karjerists. Arī par vina ğimeni esot dzirdējusi vislabāko, to visu viñai esot Ptjicins stāstījis (Dostojevskis 1929: 42-43).

В отличие от Аругих переводов, в переводе А. Межсетса не упоминается почётное звание отца Рогожина, причём имя Семён на матышском языке передано неверно:

$\ll<\ldots>$ это того самого Семена Парфеновича Рогожина, потомственного почетного гражАанина, что с месяц назад тому помре и Ава с половиной мимлиона капиталу оставиц?» (Аостоевский 1973: 9).

13 Он, говорят, энергичный человек, гордый карьерист. 
Vai tā paša Simaņa Parfenoviča Rogožina, kas pirms mēneša nomira un pustreša miljona kapitāla atstāja (Dostojevskis 1929: 10).

При переводе фрагментов, характеризующих князя Мышкина, А. Межсетс следует оригинацу, Аословно передаёт описание внешности, без сокращений воспроизводит объёмные монологи, поэтому у читатемя созАаётся полное и в целом адекватное преАставление о главном герое. Но в отношении Аругих персонажей этот принцип не соблюдается, что приводит к существенной трансформации образов романа, как это происходит, например, с образом Настасьи Филипповны. Переводчик значительно сократил описание портрета Настасьи Филипповны, выполняющее важную сюжетную функцию, так как оно знакомит читателя с главной героиней ещё до её появления, раскрывает сложность и противоречивость её характера:

«На портрете быма изображена действительно необыкновенной красоты женщина. Она быма сфотографирована в черном шелковом платье, чрезвычайно простого и изящного фасона; волосы, по-видимому, темно-русые, были убраны просто, по-домашнему; глаза темные, глубокие, моб задумчивый; выражение мица страстное и как бы высокомерное. Она была несколько худа мицом, может быть, и бцеАна» (Аостоевский 1973: 27).

В переводе сохранена мишь начальная часть описания: Portrejā patiesi bija saskatāma ārkārtīgi skaista sieviete (Dostojevskis 1929: 30), в результате чего Настасья Филипповна преАстаёт переА читателем как необыкновенно красивая женщина, страстность, наАломленность, высокомерие и в то же время беззащитность - все эти черты в переводе не упомянуты. Значительно сокращается описание приезда Анастасии Филипповны к Тоцкому, когАа она узнаёт о его возможной женитьбе. В тексте перевода отсутствует фрагмент, передающий размышкения Тоцкого:

«Он припоминал, впрочем, и прежде мгновения, когАа иногАа странные мысли приходили ему при взгляде, например, на эти глаза: как бы предчувствовался в них какой-то гкубокий и таинственный мрак. Этот взгляА глядеА - точно задавал загадку. В последние Ава гоАа он часто удивлялся изменению цвета мица Настасьи Филипповны: она становикась ужасно бледна и - странно - Ааже хорошема от этого. Тоцкий, который, как все погумявшие на своем веку Ажентльмены, с презрением смотрел вначале, как дешево досталась ему эта нежившая Ауша, в последнее время несколько усумнился в своем взгляде. Во всяком случае, у него положено было еще прошлою весной, в скором времени, отлично и с достатком выдать Настасью Филипповну замуж за какого-нибудь благоразумного и порядочного господина, скужащего в Аругой губернии. (О, как ужасно и как змо смеялась наА этим теперь Настасья Филипповна!)» (Аостоевский 1973: 38). 
В результате столь значительных сокращений у читателя нет возможности понять мотивировку поведение главной героини. В данном скучае выбор стратегии перевода обусловлен не только типом изАания, но и Аичной интерпретацией переводчика, влияющей на трактовку персонажей.

\section{Литература}

Аостоевский, Ф. (1973). ИАиот. В: Полное собрание сочинений в тридизати томах. Том 8. АенинграА. 510 с.

Панченко, А. (1999). Юродивые на Руси. В: Русская история и культура: Работы разных лет. Санкт-Петербург: Юна. С. 392-407.

Dostojevskis, F. (1929). Kņazs Miškins (Idiots): romāns 4 daḷās / tulkojis Augusts Mežsēts. Rīga: Grāmatu Draugs. 242 lpp.

Dostojevskis, F. (1936-1938). Idiōts. No: Kopoti raksti. 11.-12. sēj. / tulkots no krievu valodas. Rīga: Grāmatu draugs.

Dostojevskis, F. (1961). Idiots: romāns 4 daḷās. / tulkojis J. Medenis. Rīga: Latvijas Valsts izdevnieciba. $711 \mathrm{lpp}$.

Dostojevskis, F. (1966-1967). Idiots: romāns 2 grāmatās. Mineapole: Tilts.

Dostojevskis, F. (1975). Idiots. No: Kopoti raksti. 6. sēj. / no krievu valodas tulkojis J. Medenis. Rīga: Liesma. 662 lpp.

Dostojevskis, F. (1999). Idiots: romāns / no krievu valodas tulkojis Jānis Medenis. Rīga: Jumava. 711 lpp.

Dostojevskis, F. (2015). Idiots / no krievu valodas tulkojis Jānis Medenis. Rīga: Zvaigzne ABC. 718 lpp.

\section{F. Dostojevska "Idiots" latviešu tulkojumos}

Rakstā aplūkoti Fjodora Dostojevska romāna "Idiots" tulkojumi latviešu valodā. Raksta autores salīdzinošā aspektā analizē trīs F. Dostojevska romāna tulkojumus: Augusta Mežsēta 1929. gada tulkojumu, Zentas Mauriņas 1936.-1938. gada tulkojumu un Jāṇa Medeṇa 1961. gadā publicēto tulkojumu. İpaša uzmanība veltīta literārā tulkojuma stratēgijām un problēmām. Autores sniedz īsu biogrāfisku uzziṇu par katru tulkotāju, kā arī ziņas par izdevniecībām, kas publicējušas romānu "Idiots" latviešu tulkojumā.

\section{Latvian translations of F. Dostoyevsky's "Idiot"}

The article discusses the translations of Fyodor Dostoyevsky's novel "Idiot" into Latvian language and holds a comparative analysis of three translations performed by Augusts Mežsēts (1929), Zenta Mauriņa (1936-1938) and Janis Medenis (1961). The analysis focuses on the major challenges and strategies of literary translation. The research is introduced by a brief biographical entry on each of the translators as well as some information on the publishing houses that have published the Latvian translations of "Idiot". 
DOI: http://doi.org/10.22364/ruslat.glp.04

\author{
Наталья Шром, Наталья Михаленкоำ
}

\title{
Утопия войны в русской и латышской литературе 1920-х годов
}

В статье рассматриваются основные утопические сюжеты 1920-х годов, характерные как Аля русских, так и Аля матышских авторов (В. Маяковский, С. Григорьев, А. Чаянов, П. Эрманис, Скую ФриАис, А. Гулбис). Высказывается преАпоможение о том, что раскрытие сюжета вооруженного конфликта в утопической митературе периода посме Первой мировой войны было архетипичным, призванным обратить читателя к проблемам бескровного ведения войны, управления природными процессами, сохранения традиционной национальной культуры. Особое внимание удемяется концепции прометеизма и соответствующему ей типу героя.

Ключевые слова: утопия, антиутопия, утопия войны, утопия реконструкции, сюжет вторжения, прометеизм, В. Маяковский, С. Григорьев, А. Чаянов, П. Эрманис, Скую Фридис, А. Гулбис

Художественное пространство 1920-х годов преАставляет собой широкое и разнообразное поле утопизма. Стремление европейской авангарАной культуры модернизировать общество явилось закономерным результатом глобальных политических катаклизмов начала XX века - Первой мировой войны и последовавших за ней социально-политических революций. В этот процесс утопической социацьной модернизации вовлекается вся Европа в илеале весь мир и Ааже космос ${ }^{2}$. Так, чаемый В. Маяковским земной рай был не мыслим Аля поэта вне идеи мировой революции, которая виделась Маяковскому в «Пятом Интернационале» (1922) как символическая красная буря, налетающая из России и охватывающая все «пять частей оторопевшего света» (Маяковский 1957: 130).

ОАной из распространенных утопических концепций 1920-х годов в произведениях писателей разных стран становится так называемая утопия войны. Аостаточно вспомнить поэмы В. Маяковского «150 $000000 »$ (1919-1920) и «Иетающий пролетарий» (1925), «Трест А.Е.» И. Эренбурга (1923) и пародирующий Эренбурга «Остров Эрендорф» В. Катаева

1 Статья подготовмена в Институте мировой митературы им. А.М. Горького РАН в ходе работы по гранту Российского научного фонАа (проект РНФ № 17-18-01432).

2 Об этом, в частности, свидетельствует и достаточно распространенный в русской советской и эмигрантской митературе так называемый марсианский сюжет. 
(1925), совместный роман Вс. Иванова и В. Шкловского «Иперит» (1925), небольшую трилогию Сергея Григорьева, включающую рассказы «Московские факиры», «Новая страна» и «Гибель Британии» $(1925-1926)^{3}$, а также своего рода художественный контраргумент матышской митературы - «роман будущего ${ }^{4}$ Скую Фридиса (ГотфриАа Мимберга) «ВосхоА белого солнца» (1924). Благодаря частотности сюжет военного вторжения России в Европу (реже наоборот - например, в «Путешествии моего брата Алексея в страну крестьянской утопии» (1920) А. Чаянова и в трилогии С. Григорьева) приобретает статус архетипического: «суммарная картина Аекадентского Запада»; «война, вызванная открытием, которое способно изменять историю (гипнотический аппарат, делающий мюбое оружие бесполезным, смертоносные кучи, волновая машина, вызывающая панический страх), или политическим кризисом; в финале - созыв Мировых Советов» (Геммер, Нике 2003).

Мы видим своей задачей дополнить эту жанрово-тематическую матрицу и указать на ряА ее особенностей.

Войны будущего в утопиях - это сражение интемлектов, в идеале исключающее бойню и человеческие жертвы.

В произведении А. Чаянова германская агрессия против страны крестьянской утопии оказывается бессмысленной, так как усовершенствованная техника утопического государства («метеофоры», помогающие в регумяции атмосферных явлений, в управлении погодой) способна справиться с неприятелем без жертв со своей стороны и вынудить берлинское правительство объявить о капитуляции уже через Ава часа после начала войны:

«Алексей узнал, что 7 сентября три армии германского Всеобуча, сопровожАаемые тучами аэропланов, вторглись в пределы Российской крестьянской республики и за сутки, не встречая никаких признаков не только сопротивления, но Ааже живого насемения, углубились на 50, а местами и на 100 верст. В 3 часа 15 минут ночи на 8 сентября по заранее разработанному плану метеорофоры пограничной полосы Аали максимальное напряжение симовых Аиний на циклоне малого радиуса, и в течение получаса мимлионные армии и десятки тысяч аэропланов были буквально сметены чудовищными смерчами. $<\ldots .>$ Через два часа берлинское правительство вынуждено сообщить о капитумяции» (Чаянов 2006: 273).

В рассказе Григорьева «Гибель Британии» Аействия Великобритании, объявившей войну Новой Стране в ответ на то, что ее силами был

3 В исследовании французских филологов-славистов Аеонида Гемлера и Мишеля Нике, посвященном утопизму в России (Гемлер, Нике 2003), названы десятки произведений этой тематики.

4 Авторское жанровое опредемение. В оригинале - Milbergs G. (Skuju Frīdis). Sidrabota saule lec. Nākotnes romāns. 
организован «обвал на Памирах - крыше мира», потрясший «самые отАаленные столпы вселенной» («Обрушияся купол святого Петра в Риме. Разрушено Вестминстерское аббатство. Нотр-Аам в Париже - груда кирпича. Небоскребы Нью-Йорка - горы мусора в дыму и пламени ... » (Григорьев 1926), выгляАят крайне неразумными. Сами британцы и американцы говорят о безумии такой войны, но, охваченное жаждой мести, английское правительство открывает военные действия. Техника Новой Страны намного опережает техническое развитие Великобритании, что очевидно на примере организации ткацкого производства в Авух этих странах:

«Наши ткацкие станки и в конце Авадцатого века остаются в основе своей похожи на станок первобытного дикаря. В Новой Стране смеются наА нами: там совершенно покинут наш дикарский немепый ткацкий станок, и построены рациональные машины Аля произвоАства тканей, подобных удивительно прочным покровам так называемых “низших животных", - назову хотя бы чешуйчатые ткани, прочность которых основана на геометрических свойствах их рисунка. А мы все еще гордимся Жакардовым станком» (Григорьев 1926).

Характерной особенностью борьбы Новой Страны с британской агрессией явмяется элегантное по замыслу и техническому воплощению сАерживание каких-либо военных действий противника: «Британцы не ожиАали, что им придется сражаться с врагом, вооруженным не оружием, а орудиями труАа». Воздушные силы Новой Страны, используя природную технику плетения паучьей сетки, смогли накрыть «аэротканью» всю Великобританию - «от Оркнея до Фальмута и от Корка до Ярмута»:

«В то время, как британские самометы снаряжались Аля Аальнего полета, наА островами Англии внезапно появились цемой тучей в несколько десятков тысяч аппаратов аэропланы типа пылесеев. Они разделились на Аве группы: первая понеслась стройным рядом с юга на север и с севера на юг, выпуская после себя тонкую и мегкую нить, - это была основа аэроткани; межАу тем, Аругая группа самометов начала, подобно челнокам в ткацком станке, переплетать основу нитями утока... Истребители, поднявшись Аля погони за врагом, наткнулись на падающую сверху сеть и запутались в ней» (Григорьев 1926).

В романе Скую Фридиса «Восход белого солнца» Аействие перенесено в относительно Аалекое будущее: «В 2107 году Московия объявила

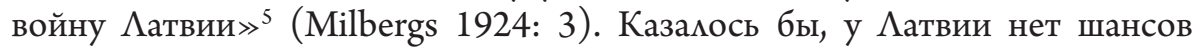
противостоять огромному, сильному и воинственному соседу. И тем не менее роман заканчивается парадом матвийских войск у стен покоренного

5 ЗАесь и Аалее перевод Натальи Шром. В оригинаме: “2107. gadā Maskavija pieteica Latvijai karu”. 
Кремля. Помогла $А$ атвии и военная хитрость - перелом в войне наступает тогАа, когАа матвийские аэропланы проникают на территорию Московии, а именно в Бородино, откуда они и атакуют Москву, практически сжигая ee (Milbergs 1924: 53). Но главным источником победы становится наука, благодаря которой то, «что не смог сАелать Наполеон, сАелала сейчас маменькая матвийская армия ${ }^{6}$ (Milbergs 1924: 212). На протяжении романа Скую Фридис описывает немало изобретений матвийских ученых 7 . Особое значение (во всех смыслах - и сюжетном, и концептуальном) приобретает последнее - оно приносит Аатвии победу и в нем соединяются усилия преАставителя науки (химика Акота, созАателя нового парализующего газа) и преАставителя искусства (музыканта, профессора Кокле, изобретателя особой трубы, звучание которой распространяет звуковые волны вместе с газом). Новые теурги Акотс и Кокме сравниваются с библейским Иисусом Навином, чьи трубы разрушили стены Иерихона (Milbergs 1924: 219).

Концептуально большая часть утопий войны написана в соответствии с философией прометеизма - концепцией покорения материального мира с помощью современной науки и техники. Заметим, что в стране крестьянской утопии Чаянова государственным гимном стал «Прометей» А.Н. Скрябина - это музыкальное произведение исполняется не в концертном зале, а колоколами всех московских церквей. Весь утопический гороА объединен музыкой, зовущей к теургическим свершениям. Характерной чертой амя утопии Чаянова явмяется то, что издержки, вызванные военными действиями, Германия должна выплатить, в частности, произведениями искусства (важной особенностью крестьянской страны явмяется высокая искусствоведческая образованность населения): формой контрибуции «русский Совнарком избрал несколько десятков полотен Боттичемли, Аоменико Венециано, Гольбейна, Пергамский алтарь и 1000 китайских раскрашенных гравюр эпохи Танг, а также 1000 пмеменных быков-производителей» (Чаянов 2006: 273-274).

В оригинаме: "Ko Napoleons nebij varējis veikt, to tagad izdarija maza Latvijas armija”. «В военном Аеле использовались все новые и новые изобретения. Противогазами были нейтрализованы газы. Быстрым самолетам противостояли еще более быстрые. Работу артимерии парализовали установменными в определенных местах огромными эмектромагнитами... <...> Профессору Красту уАалось создать химическое вещество, которую можно было использовать вместо хиеба. Аругой профессор ... отправиц в штаб армии новоизобретенное взбадривающее среАство. Оно снимало усталость, уничтожало бацимлы сна, восстанавмивало израсходованную энергию». В оригинаме: "Kara mākslā nāca klāt arvien jauni izgudrojumi. Gāzes likvidēja ar pretgāzēm. Ātrām lidmašīnām stādỉja pretī vēl ātrākas. Artilērijas darbību paralizēja ar zināmās vietās uzstādītiem milzịgiem elektromagnētiem ... <...> Profesoram Krastam bij izdevies radīt kīmisku vielu, kuru varēja lietot maizes vietā. Kāds cits profesors ... bij iesūtīijis armijas štāba jaunizgudrotu atspirdzināšanas līdzekli. Līdzeklis atñēma nogurumu, iznīcināja miega baciḷus, atjaunoja izlietoto enerǵiju” (Milbergs 1924: 209, 211). 
Как виАим, взгляды русских и матышских авторов на роль искусства в новом мире оказываются близкими и созвучными мефовской жизнестроительной концепции искусства: «Но ески / я говорю: / “А!” - / это “а” / атакующему человечеству труба. / Если я говорю: / “Б!” - / это новая бомба в человеческой борьбе» (Маяковский 1957: 108). В «Пятом Интер-

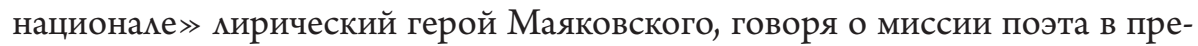
ображенном мире, мыслит себя теургом:

Поэзия - это сиАи и наА розой ной ...

Аля меня

невыносима мысль, что роза выдумана не мной.

Я 28 мет отращиваю мозг не Аля обнюхивания, а Аля изобретения роз. (Маяковский 1957: 107)

Как писала Светлана Семенова, обобщая положения Маяковского, «искусство в своем высшем дерзании хочет стать не отражением жизни, не передачей впечатлений от нее, а силой, творящей самое жизнь» (Семенова 2001: 175).

В предельно заостренной форме идея от слова к делу выражена и в небольшой Араматической поэме Петериса Эрманиса 1921 года «Россия». В фантасмагорической антиутопии Эрманиса новая власть в новой России преАстает в образе гротескного чудовища - пятиеАиного императора: «Пять это - Иван Грозный, Петр Первый, Потемкин, Аракчеев и Троцкий» ${ }^{8}$ (Ërmanis 1921: 5). Новую власть обскуживает новое искусство: стимистически поэма пародирует «Авенадцать» Блока. Экспиицитно Блок присутствует в поэме как автор «Скифов». Мимлионы глоток, перекрикивающие рев ветра и снежной бури, в качестве революционной песни орут на русском языке: «Аа, скифы мы, Аа азиаты мы с раскосыми и жаАными очами» (Ērmanis 1921: 5). Также экспиицитно в поэме названы $\Lambda$ начарский и Маяковский: «Пкакат на стене, красный, черными буквами “Сегодня в MXТ “Жизнь за царя”. Мистерия-буфф в пяти картинах Ауначарского и Маяковского” ${ }^{9}$ (Ērmanis 1921: 5) ${ }^{10}$. Важным Аоводом в пользу

8 В оригинале: "Pieci: Jāns Briesmīgais, Pēteris Lielais, Potjomkins, Arakčejevs, Trockis".

9 В оригинале: "Plakāts pie sienas, sarkans, melniem burtiem: Šovakar Dailes teātrī DZĪVĪBA PREEKŠ CARA! Misterija-bufs piecās ainās no Lunačarska un Majakovska”.

10 Надо заметить, что художественная фантазия Эрманиса исторически очень точна. Именно А.В. Ауначарский оАним из первых пытался приспособить оперу ГАинки к обстоятельствам нового времени. Вот как пишет об этом в своих мемуарах $е$ еони Сабанеев: «Ауначарский ... полагал, что героика оперы вполне согласуется с героикой советского новорожденного народа и что достаточны небольшие изменения. В соответствии с этим Иван Сусанин обратился в «преАсельсовета»... Ваня обращен был в комсомольца. Поляки остались на месте потому, что в это время как раз была война с Польшей, где выдвинулся Тухачевский» (Сабанеев 2005). 
утвержАаемом Эрманисом жизнестроительной концепции искусства явмяется то, что в его тяготеющем к постмодернистской эстетике тексте наряАу с реальными историческими персонажами сосуществуют герои русской классической митературы - новому строю радуется делец Чичиков, в помощниках пятиголового царя не только начальник охраны Малюта Скуратов и трубочист Петерис Стучка, но и министр СмерАяков. Антагонистами новой власти у Эрманиса выступают герои киассической русской митературы - Аиза Камитина, Митя РуАин и Алеша Карамазов, а также еще Аве тысячи митературных НаАь, Петь, Ань, Миш, Коль, которые в начале только то и Аелают, что «говорят и говорят»: «Топот ртов, грохот ртов, гранАиозная фабрика болтовни» (Ērmanis 1921: 5) ${ }^{11}$. В финале поэмы благословмяемая Пресвятой Богородицей Аиза взрывает Кремль и уничтожает пятиголовое чудовище. Как и у Маяковского, у Эрманиса искусство - это сила, творящая самое жизнь.

Концепция прометеизма открывала путь улучшению социальной системы, но, с Аругой стороны, вела к уничтожению национальной культуры, национальной идентичности. Это опасение объединяет, казалось бы, идеологических оппонентов - русских и матышских утопистов, что приводит их к схожим поискам решения проблемы - к манифестации возврата к ретро-перспективному утопизму, согласно которому идеальное будущее неотличимо от иАеализируемого прошиого - от Золотого национального и культурного века (что бы под этим не понимали авторы утопий).

Утопия Чаянова - это своеобразный синтез технического прогресса и Аопетровских культурных традиций, это принципиальное возвращение к традиционным ценностям. Жители чаяновской утопии с мегкостью говорят о «Ван Гоге», властителем их помыслов стали «сузАальские фрески XII века» и работы реалистов с «Питером Брейгелем как кумиром». ПоА аккомпанемент клавесина утопическая женщина Катерина Минина поет романс А. Александрова на стихи Г. Аержавина «Шекснинска стерляАь зомотая... ». Обычаи и устои утопической страны коренятся в минувшем, реставрируют и возрожАают его. Так, проводятся международные состязания «на звание первого игрока в бабки». Меню обеда утопических жителей соответствует «Русской поварне» Аевшина $(1816$ года): «... на обеАенный стол появлялось такое количество расстегаев и кулебяк, запеченных карасей в сметане и прочей снеАи» (Чаянов 2006: 253). САовно повторяя сюжет Аымковской игрушки, герои «Путешествия ... ґ пьют чай: «Через минуту на кужайке архангельского парка <..> гости были усажены у шумящего самовара за стол, на мьняных скатертях которого высились горы румяных ватрушек» (Чаянов 2006: 236). И если у Маяковского в Москве будущего не будет ни переулков, ни улиц, а только аэродромы и сорокоэтажные Аома, то чаяновская Москва 1984 года - не мегаполис, теснящий тайгу, а заполненный садами город-пигмей: «Город казался сплошным парком, среАи

11 В оригинале: "Mutu klaboṇa, mutu dārdoṇa, pḹpības fabrika grandioza”. 
которого архитектурные группы возникали направо и налево, походими на маленькие затерявшиеся городки» (Чаянов 2006: 229). Вступающая в войну чаяновская «Аеревенская Россия» вывоАит, «подобно АяАьке Черномору», «из своих неАр тридцать три богатырские силы». Чаянов созАает образ страны мубочного рая: «Плотные колонны войск быстрыми шагами французских шассеров проходили по шоссе переА окнами. Какая-то молоАая Аама в голубой амазонке, на белом коне и с генеральским султаном принимаха параА мегкой кавалерии амазонок» (причем военная форма «крестьянской гварАии» напоминает «живописные костюмы стрельцов эпохи Алексея Михайловича») (Чаянов 2006: 271).

Утопическим илеям крестьянского эдема Александра Чаянова близка позиция Скую ФриАиса ${ }^{12}$. В романе «Восход белого солнца» Россия XXII века изображена согласно жанру ретроспективных утопий, или ретроантиутопий, в которых будущее неотличимо от прошлого и представляет собой реконструкцию Аопетровской России, России Рюриковичей, чаще всего эпохи правления Ивана Грозного. В начаме романа Скую Фридис преАлагает небольшой исторический экскурс, из которого читатемь узнает, что власть большевиков продержалась неАолго - 27 мет. Крушение коммунистической идеологии сопровожАалось развалом страны, распавшейся на множество самостоятельных государств. Отпали не только Сибирь, Кавказ, Украина, но и Петербургско-Беморусская республика. Возникшая на руинах Московия возвращается к монархическому управлению ${ }^{13}$. Аатышский автор разделяет точку зрения эмигрантских утопий 1920-х годов («Во мгле грядущего» И. Наживина (1921), «Аиктатор мира» А. Ренникова (1925), о том, что коммунистическая империя падет сама по себе, а посткоммунистическая Россия вновь станет монархической. Такова схема и романа генерала Петра Краснова «За чертополохом» (1922, Аважды издавался в Риге, в 1928 году в авторской редакции).

12 И если «Путешествие моего брата Алексея в страну крестьянской утопии» - художественная утопия Чаянова - была матышскому читателю не известна, то экономические труды российского ученого, в частности его «Основные идеи и формы организации крестьянской кооперации», обсужАамись на страницах матышских периодических изАаний. В статье «Пролетарский рай и крестьянский эдем - утопии Маяковского и Чаянова» Н.В. Михаленко показала, что, создавая картину утопической России в «Путешествии ... », Чаянов опирался на свои экономические, педагогические, искусствоведческие идеи. Научные идеи Чаянова приняли в «Путешествии ... » художественную форму (Михаленко 2017).

13 События в романе начинаются тогАа, когАа после смерти императора Ивана V к власти приходит его сын Кирим I. Он и объявяяет войну Аатвии, использовав Аля этого ничтожный повоА - на торжества по случаю коронации не приехац один-еАинственный посланник, не вовремя заболевший преАставитель Аатвии БалоАис. По иронии, «Балодис», по-латышски «голубь», не выполняет свою миссию посланника мира. 
Концептуально этой идее близка и поэма Эрманиса «Россия». В уста Троцкого - оАной из ипостасей пятиединого императора - Эрманис вкАаАывает квинтэссенцию антиутопического мышкения: «Товарищи-рабочие, товарищи-солдаты, скушайте меня. Красное - это черное. Черное - это красное. Новое - это бывшее старое. Монарх - коммунист, коммунист - монарх $\gg$. Аатышские авторы уверены, что новое - это Аишь мишура, прикрывающая старую имперскую сущность. Точный символический образ такой ново-старой России преАложил Скую Фридис: московский царь Кирим 1 торжественно проехал по Петербургу на украшенном жемчугом и Арагоценными камнями аэроплане, который по петербургским улицам тащили взятые из зоопарка Авенадцать меАвеАей, АвенаАцать оленей и Авенадцать волков (Milbergs 1924: 7).

Несмотря на то, что последние страницы романа «Восход белого солнца» преАставмяют собой утопические картины Москвы, освобожденной от тирании Киримла 1 , - хмеб-соль от Аемегации торговцев и промышменников, АожАь из цветов от горожан, поцекуи от девушек, автор видит «во всем этом ... свои негативные стороны» (Milbergs 1924: 285). Согласно Скую Фридису, чемовек новой свободной Европы - и матыш, и русский - Аолжен отказаться от чудодейственной помощи техники и вернуться к естественности первозАанной природы. Это позволяет уточнить смысл финальных эпизодов романа «ВосхоА белого солнца». Прошио только пять Аней посме прихода матышей, но жизнь удивительно быстро приспособиАась к новым обстоятельствам. Москва уже напоминает Аатвийский гороА на улицах звучит матышская речь, торговцы предлагают матышские сувениры, в гостиницах и ресторанах готовят традиционные матышские блюАа, «которые вошли в моду, как и все матышское» (Milbergs 1924: 284-285). Трактовка иАилмической Москвы у Скую Фридиса - это не торжество идеи колонизации, матышскость в Аанном случае и означает возвращение к природности, к естественности. Вот почему мейтмотивом в этих сценах звучат народные матышские песни, культивирующие изначальную гармонию синкретического единения чемовека и природы: Aiz upites es izaugu («3а peченькой я выросла... »).

Тенденция к природности подкрепляется такой важной и парадоксальной особенностью утопических войн, как экологичность. В романах Скую Фридиса и Чаянова, в рассказах Григорьева утопическая страна способна противостоять всей военной мощи противника с помощью использования природных в своей основе технологий, мишь развитых и максимально усиленных техническим прогрессом. Так, в рассказе Григорьева фмот Вемикобритании парализован с помощью засевания Босфора, Гибралтара, Суэзского канала и нового морского канала, соединяющего Черное море с Каспием, «чрезвычайно быстро растущей водорослью, в которой путались и застревали винты Аредноутов и крейсеров» (Григорьев 1926). Интемлектуальный характер сражений будущего не допускает превращение войны в бойню, исключает человеческие жертвы как таковые. Фактически, и Новая 
Страна, и Аатвия Скую Фридиса применяет биологическое оружие гигантской силы воздействия, способное парализовать мюбые действия противника, но не убивать его: «В первый раз за всю историю человечества война, которую вела величайшая мировая Аержава, превратилась в веселый фарс» (Григорьев 1926).

Утопия войны, ставшей «в высшей степени гуманной» (Milbergs 1924: 221) или превратившейся в фарс, практически изживает себя в 1930-е годы. В матышской митературе сюжет вторжения окончательно принимает пацифистский характер. В утопии Ансиса Гулбиса «Новое государство» (1933), концептуально и Ааже стилистически ориентированной на «Поэзию рабочего удара» Алексея Гастева, речь уже идет о колонизации Сибири как о мирном вторжении Европы в Россию.

При всем жанрово-тематическом разнообразии утопий 1920-х годов, основные ее сюжеты были близки, а конфмикты развивались по некоторым определенным сценариям, которые связаны с решением проблемы ведения бескровной войны или военных Аействий с минимальными жертвами, Аостижения такого уровня технического прогресса, чтобы человек мог управмять явлениями природы, не нарушая при этом целостности экологических систем, а также сообразуя свою деятельность с необходимостью сохранения культурного наслеАия преАшествующих эпох.

\section{Литература}

Гемлер, А., Нике, М. (2003). Утопия в России. Санкт-Петербург: Гиперион. 312 с. Аоступен на 05.11.2018: https://profilib.org/chtenie/80307/leonid-geller-utopiya-vrossii.php

Григорьев, С. (1925-1926). Гибель Британии. Всемирный следопыт. № 1 (10), 2, 3. Аоступен на 05.11.2018: https://profilib.org/chtenie/46876/sergey-grigorev-gibelbritanii-zhurnalnyy-variant.php

Маяковский, В.В. (1957). Пятый Интернационал. Полное собрание сочинений: В 13 m. / АН СССР. Институт мировой митературы им. А.М. Горького. Москва: Государственное издательство художественной митературы. 1955-1961. Т. 4. Стихотворения 1922 года, поэмы, агитлубки и очерки 1922-1923 годов. С. 105-134.

Михаленко, Н.В. (2017). Пролетарский рай и крестьянский эдем - утопии В.В. Маяковского и А.В. Чаянова. Русская словесность. № 2. С. 68-74.

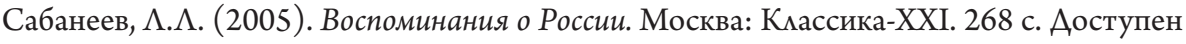
на 05.11.2018: http://www.belousenko.com/books/memoirs/sabaneev_vosp_o_ rossii.htm

Семенова, С.Г. (2001). «Новый разгромим по миру миф...» (ВАадимир Маяковский). Русская поэзия и проза 1920-1930-х годов. Поэтика - Видение мира - Философия. Москва: ИМАИ РАН, «Наследие». С. 144-211.

Чаянов, А.В. (2006). Путешествие моего брата Алексея в страну крестьянской утопии. Московская гофманиада. Москва: ТОНЧУ. С. 217-275.

Ërmanis, P. (1921). Krievija (= Россия). Latvis. Nr. 46. 5. lpp.

Milbergs, G. (Skuju Frīdis) (1924). Sidrabota saule lec (= Восход белого солнца). Nākotnes romāns. Riga: Latvijas Aizsardzības Biedrïba. 308. lpp. 
Kara utopija 20. gadsimta 20. gadu krievu un latviešu literatūrā

Rakstā aplūkoti galvenie 20. gadsimta 20. gadu utopiskie sižeti, kas raksturīgi krievu un latviešu autoriem (V. Majakovskis, S. Grigorjevs, A. Čajanovs, P. Ėrmanis, Skuju Frīdis, A. Gulbis). Raksta autores secina, ka sižets par bruṇotu konfliktu utopiskajā literatūrā laikā pēc Pirmā pasaules kara ir arhetipisks. Lasītāja uzmanība vērsta uz vairākām problēmām: ir iespējams karš bez asinīm, pār dabas procesiem var valdīt, tradicionālā nacionālā kultūra ir jāsaglabā. İpaša uzmanība veltîta prometeisma koncepcijai un tai atbilstošam varoṇa tipam.

\section{Utopia of War in the Russian and Latvian Literature of the 1920s}

The article examines basic utopian plots of the 1920s, characteristic of both Russian and Latvian writers (V. Mayakovsky, S. Grigoryev, A. Chayanov, P. Ërmanis, Skuju Frīdis, A. Gulbis). The authors of the article assume that the development of the plot of the armed conflict in the utopian literature of the period after World War I was archetypal, designed to draw the reader's attention to the problems of bloodless warfare, management of environmental processes, preservation of traditional national culture. The special attention is paid to the concept of prometheism and the corresponding type of a character. 
DOI: http://doi.org/10.22364/ruslat.glp.05

\section{Элина Круповича}

\section{Приходская жизнь Рижской церкви Всех Святых до 1914 года}

Рижская церковь Всех Святых расположена на территории бывшего Московского форштадта. В 1777 году на территории кладбища в районе нынешних улиц Католю, $\Lambda$. Кална, Ааугавпилс на территории кладбища была построена часовня во имя Всех святых, и кладбище получило название Всехсвятского. Эту Аату можно считать началом истории Всехсвятской церкви. В 1812-1814 годах на месте часовни была построена деревянная церковь, приписанная к Рижской Благовещенской церкви. В 1852 году Всехсвятская церковь становится самостоятельным приходским храмом. В 80-90х годах 19 века начинается новый этап в развитии архитектурного ансамбмя церкви: завершено строитемьство нового каменного зАания церкви (1884 г.) и построено зАание церковно-приходской школы (1892 г.). К началу Первой мировой войны Всехсвятская церковь была крупным религиозно-просветительским центром преАместья ${ }^{1}$.

Ключевые слова: Рига, Московский форштадт, русское население Риги, православные приходы, приходская жизнь

\section{Из истории формирования архитектурного ансамбля церкви}

Рижская церковь Всех Святых расположена на улице Католю, 10, на территории старейшего преАместья Риги - Московского форштаАта ${ }^{2}$. Аокументальные сведения о наличии первой в Риге православной церкви во имя Св. Николая Чудотворца и клаАбища при ней относятся к 1453 году. ОАнако храм был сооружен значительно раньше, видимо, около 1229 года, когда в Риге появилась колония (Авор) купцов из Аревнерусских земель. Рижская Св. Николаевская церковь функционировака только метом, когАа в город приезжали русские купцы. В 1616 году зАание церкви еще существовало, однако после занятия в 1621 году Риги швеАами больше в письменных источниках не упоминается. ВиАимо, к этому времени зАание

1 В Аанной статье история приходской жизни церкви Всех Святых до 1914 года отображена на основе материалов периодической прессы, изданных до 1914 года. Истории приходской жизни церкви Всех Святых в 20-30-е годы XX века посвящена отдельная статья, основанная на периодических изАаниях 20-30-х годов. Подробнее см.: Круповича 2005: 201-207.

2 Ао 1934 года предместье носимо название Московского форштадта, потом было переименовано в $\Lambda$ атгальское предместье. 
Св. Николаевской церкви было уже разобрано. Неизвестен ни внешний виА этого храма, ни его планировка, ни Ааже точное место его расположения (предположительно, храм находился в районе улиц М. Трокшня и Атгриежу). Аругих православных храмов на территории Иифмяндии до 18 века не было. В 1715 году рядом с городскими укреплениями, неАалеко от Кармовских ворот, на среАства, пожертвованные русскими купцами Риги, была построена Аеревянная церковь во имя БАаговещения Пресвятой Богородицы с приделом во имя Св. Николая Чудотворца. Уже в 1773 году в связи с сооружением новых фортификационных сооружений вокруг Риги зАание этой церкви бымо разобрано, а из её материалов на православном кладбище Риги (в районе нынешних улиц Католю, $\Lambda$. Кална, Ааугавпилс) в 1777 году была построена часовня (Гаврилин 2001: 79, 80, 86). Часовня была освящена во имя Всех Святых и само кмадбище стало называться Всехсвятским (Вахрамеев 1912: 304).

Русское купечество Риги осталось без своего храма, поэтому было принято решение на Московском форштадте, в районе так называемого «Гостиного Авора» и скиадов русских купцов (в районе улицы Гоголя) отвести место Аля строительства новой церкви. Аеревянная «русско-рынская» Благовещенская церковь была построена в 1774-1778 годах (Гаврилин 2001: 86, 87). ОАнако вскоре часовня во имя Всех Святых стала не вмещать всех момящихся. Поэтому в 1812 году рядом со Всехсвятской часовней начинается строительство церкви. К мету 1812 года зАание уже бымо подведено поА крышу. В 1812 году Благовещенская церковь сгорела, но её церковную утварь успели перенести в ещё недостроенную Всехсвятскую церковь. Строительство церкви продолжили сразу же посме окончания Отечественной войны 1812 года. При Всехсвятской церкви в 1814 году был основан приход. В 1815 году храм быи освящён во имя Всех Святых (Вахрамеев 1912: 304). Немецкий историк В. Гутцейт так описывал церковь Всех Святых: построена в византийском стиле, деревянная, на высоком фундаменте, с одним главным и четырьмя боковыми куполами, с отдельно стоящей колокольней (Gutzeit 1868: 411). 10 июня 1814 года на месте сгоревшей Рижской Благовещенской церкви была заложена новая деревянная церковь на каменном фундаменте, также во имя БАаговещения Пресвятой Богородицы ${ }^{3}$ (Гаврилин 2001: 88).

В 1852 году приход Рижской церкви Всех Святых, ранее приписанный к Рижскому Благовещенскому приходу, стал самостоятельным приходом. Большая часть прихожан Благовещенского прихода была приписана ко Всехсвятской церкви. Приходу церкви Всех Святых был назначен штатный причт, состоящий из священника, Аьякона и Авух псаломщиков (Вахрамеев 1912: 304).

3 ЗАание церкви сохранилось до наших дней и находится в Риге по аАресу умица Гоголя, 9. 
В 80-90-х годах 19 века начинается новый этап в развитии архитектурного ансамбля церкви во имя Всех Святых. Рижская Ауховная консистория 15 октября 1881 года заказала архитектору Янису Фридриху Бауманису ${ }^{4}$ разработку проекта нового храма с составмением эскизов на перенос старой деревянной Всехсвятской церкви «как она есть» на Ивановское кладбище (АГИА-10). В 1882 году деревянный храм разбирают и переносят на Ивановское кАадбище. Там храм собирают снова и по решению Рижской Ауховной консистории приписывают ко Всехсвятскому приходу ${ }^{5}$ (Гамлер 1884). 22 августа 1882 года на месте бывшей деревянной церкви закладывается новое кирпичное зАание. Через два года строительство было завершено. В начале 1888 года епископ Рижский и Митавский Арсений (Брянцев $)^{6}$, осматривая церкви Риги, «выразил своё удовольствие при виде обширного храма» (Посещение церквей города Риги Преосвященным Арсением 1888). Настоятель храма отец Григорий Краснянский говорил, что «стоя в храме ... стоишь как бы на небе» (Краснянский 1892: 154). Освящение нового храма во имя Всех Святых состоянось 9 мая 1891 года.

Ко Всехсвятскому приходу относились также три часовни: в воротах Всехсвятского храма, у так называемого «Русского рынка» и на Всехсвятском кладбище. Часовня на кладбище была построена по проекту Яниса Фридриха Бауманиса на средства А.Я. Камариной в византийском стиле: «Стены часовни возведены из серого гранита, внутри облицованы цветным мрамором, купол обложен снаружи цинковыми чешуями, а внутри расписан богатой живописью. В окна по образцу средних веков вставмены разноцветные стёкла, а вхоА закрывается решётчатыми Аверьми. На

4 Янис Фридрих Бауманис (1834-1891) известный мифмяндский архитектор; первый архитектор-латыш, получивший высшее образование и ставший основоположником национальной архитектуры. С 1870 года по 1880 гоА работал архитектором

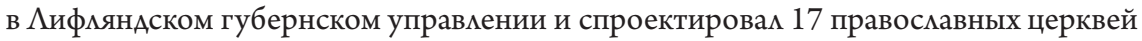
на территории Аифмянаской губернии.

511 сентября 1883 года епископ Рижский и Митавский Аонат (Соколов-Бабинский) освятил церковь в память усекновения честной главы св. Пророка и Предтечи Крестителя Господня Иоанна. В 1892 году так называемая Ивановская церковь была отделена от Всехсвятской церкви. Это зАание сохранилось на Ивановском кладбище Ао наших Аней как храм Казанской иконы Пресвятой Богородицы в районе улицы $\Lambda$. Кална, 21.

6 Архиепископ Арсений (Брянцев) (1839-1914) - епископ Рижский и Митавский. За его Аесятилетнее пребывание (с 1887 по 1897 гг.) на Рижской кафеАре было возАвигнуто 67 новых храмов и несколько часовен, образовано 26 новых приходов (общее количество приходов возросло со 169 до 195). Архиепископ ввел духовные беседы с прихожанами, устроил библиотеки и изАал много брошюр духовного соАержания. Его усердием создан Пюхтицкий женский монастырь, а в Риге основана Свято-Троицкая женская община. При всех церквях архиепископ основал библиотеки, широко развернул миссионерские беседы, учредил при духовной семинарии Историко-статистический Комитет по описанию церквей и приходов Рижской епархии. В 1896 году в Риге быи учрежАён Церковно-археологический музей. 
внутренней восточной стене церкви - икона св. мученика Павла, покровитемя П.Г. Камарина, написанная на медной доске в киоте из белого мрамора» (Краснянский 1891: 798).

19 июмя 1892 года рядом со Всехсвятским храмом начинается строительство приходской школы по проекту архитектора А.П. Кизельбаша. Найти необходимые Аля строительства средства помог случай. Благотворитель, пожелавший остаться неизвестным, переАал руковоАству Рижской епархии капитал в размере 100000 рубцей, с тем, чтобы годовые проценты с этого капитала были направлены на строитемьство школы при какой-нибуАь церкви. 11 ноября 1891 года епископ Рижский и Митавский Арсений (Брянцев) благословил выделение 4000 рублей на строительство приходской школы при Всехсвятской церкви (Краснянский 1892: 152).

9 января 1894 года зАание приходской школы (в настоящее время зАание Рижской Ауховной семинарии по аАресу улица Католю, 10) было освящено епископом Рижским и Митавским Арсением (Брянцевым). 3Аание школы было Авухэтажным. На первом этаже находился большой зал Аля общей молитвы и собраний. На втором этаже располагались Ава класса: Аля мальчиков и Аля девочек. Занятия в школе начались уже 15 января (Торжество освящения каменного Авухэтажного зАания и открытия в нём церковно-прихоАской школы 1894: 147).

Таком образом в 90-е годы 19 века завершилось формирование архитектурного ансамбця Всехсвятской церкви.

\section{Приходская жизнь}

В середине 19 века ситуация в области знаний и веры среди православного населения Московского форштадта была крайне сложной. В особенно беАственном положении находияся приход Всехсвятской церкви. «ПрихоА сей находится среАи самого многочисленного населения раскольников, которые, примером своей беспорядочной жизни, пагубно действуют на православных, увлекая их в те же пороки, которым преАаются сами, как то: пьянству, распутству, воровству и т.А. А мюАям при таком безнравственном образе жизни не Ао попечения о Ауше», - такие сведения Аают Аокументы Рижской Ауховной Консистории за 1856 гоА (АГИА-1). В Московском форштадте так же не соблюАалось узаконение, которым воспрещалось в воскресные Ани отпирать трактиры до окончания в церквях Богослужения (АГИА-2). Учитывая социальный состав жителей Московского форштадта (рабочие, ремесленники и т.А.), по документам Рижской Ауховной Консистории за 1854, 1856, 1857 и Ар. г., знания прихожан церквей Московского форштадта о начальных символах веры, заповеАях, молитвах - были неАостаточными (АГИА-5). Чтобы повысить знания прихожан в Ауховной сфере, были введены Катехизисные поучения. Во Всехсвятской церкви они читались еще в 1844 году, когАа она была приписана к Благовещенской церкви. ТогАа их читал священник Благовещенской церкви отец Иоанн Васильевич Преображенский по воскресным и праздничным Аням 


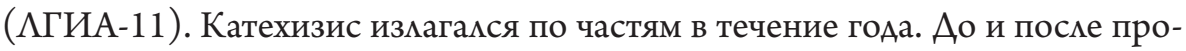
изнесения мекций священник был обязан преАставмять тексты мекций цен-

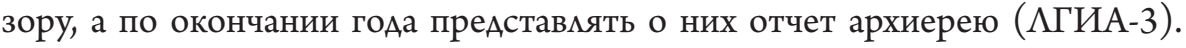
По сведениям Рижской Ауховной консистории, поучения выскушивались Всехсвятским приходом внимательно, но при этом уровень знаний оста-

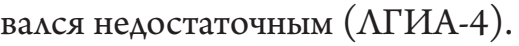

Причт Всехсвятского прихода заботился также о духовном воспитании детей. Аети бедных прихожан, обучающиеся в мютеранских школах, в воскресные и праздничные Ани собирались переА митургией на квартире священника Амя преподания им нужных ААя православного основных истин веры (АГИА-6). В последующие годы во Всехсвятской церкви чита-

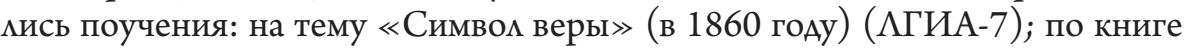
Бытия (в 1862 гоАу) (АГИА-8); по священной истории Ветхого завета (в 1863 году) (АГИА-9) и Ар.

Во Всехсвятской церкви проходили также и миссионерские бесеАы, например, 21 марта 1890 года проходили бесеАы синодального миссионера протоиерея Ксенофонта Крючкова (Епархиальная хроника 1890: 262).

В конце 1890 года по решению епископа Арсения (Брянцева) были открыты внебогоскужебные чтения при Всехсвятской церкви (Краснянский 1890: 723). Они Аолжны были проводиться по воскресным и праздничным Аням. Эти чтения отличались от обыкновенной проповеди тем, что они были более пространными, предмет изучения должен был быть рассмотрен всесторонне; в случае непонимания, аудитория могла задавать вопросы. Цель чтений состояла в религиозно-нравственном просвещении прихожан посреАством разъяснения истин веры и правил православно-христианской жизни. Чтения начались 18 ноября 1890 года. Традиция внебогоскужебных чтений привилась и в последующие годы. Так, 14 октября 1912 года были открыты очередные чтения (Религиозно-нравственные беседы в г. Риге 1913: 88). 22 октября 1912 года состоянась беседа дьякона К. Аорина на тему «Богоматерь и Россия». Епископ Рижский и Митавский Иоанн (Смирнов) разАавал брошюру Иринея ОрАы поА названием «О мживости уверения, что религия - частное, Аичное Аело кажАого». В слеАующие воскресенья были продомжены беседы на темы: 1) об иерархии (свящ. Н. Павель); 2) о священном писании (прот. В. Пиисс); 3) «об условиях спасения по учению Православной Церкви в связи с католическим и протестантским учением о свободе и благодати» (прот. В. Березский). Как сообщали «Рижские епархиальные ведомости», эти чтения отвечали запросам слушателей. КажАая беседа сопровожАалась общим одушевленным пением (Религиозно-нравственные беседы в г. Риге 1913: 88).

В 1914 году в Риге при Всехсвятской церкви были открыты народно-миссионерские курсы (Круповича 1914а: 97). Можно предположить, что Всехсвятская церковь была выбрана Аля этой миссии потому, что по утвержАению настоятемя церкви отца Г. Краснянского в 1892 году: «Всехсвятский приход есть самый многочисленный не только в городе Риге, но и 
во всей Рижской епархии» (Краснянский 1892: 154). Это положение не изменилось к 1914 году. Численность населения Московского форштадта увемичилась в связи с увеличением объема производства на фабрике по производству фаянсовой посуды купца С.Т. Кузнецова, Балтийской мьняной мануфактуре в Кенгарагсе и Ар. В пользу Всехсвятской церкви смогло сыграть и то, что она обладама нужными Аля курсов помещениями (зАанием церковно-приходской школы, построенным в 1894 году), а также квалифицированным и почитаемым прихожанами составом причта.

7 января 1914 года архиепископ Иоанн (Смирнов) в своем назидательном слове отметил, что на курсах главным образом будут разъясняться истины, подвергающиеся сомнению и отрицанию со стороны старообрядцев и сектантов (Круповича 1914а: 98). В первый Аень на курсы записалось около 200 человек. ПреАполагалось проводить занятия по вторникам и четвергам с 8 до 10 часов вечера. Расписание курсов было таким: по вторникам - чтения, объяснение посланий св. Апостолов (лектор свящ. о. А. Клинентовский), история и обличение раскола (лектор прот. о. В. Плисс), пение церковных песнопений (свящ. о. А. Андреев); по четвергам - чтение и объяснение св. Евангелия (лектор свящ. о. В. Церинь), история и обличение сектанства (Аектор свящ. о. И. Павель), пение духовных песнопений (свящ. о. А. Анареев) (Круповича 1914b: 53).

9 января состоялась первая мекция. На этом занятии присутствоваци 224 человека. Количество слушателей к 30 января Аостигло 332 человек. Как сообщали «Рижские епархиальные ведомости», все эти слушатели еАва вмещались в помещениях Всехсвятской приходской школы (Круповича 1914а: 98). Они со вниманием и интересом выслушивали беседы и чтения. Особенное оживление наступало тогАа, когАа начинацись церковные песнопения под руководством свяш. отца А. Анареева. Песнопения с УАОвольствием исполнялись и Аетьми, и АюАьми зрелого возраста. ААя того, чтобы их можно было петь не только на курсах, но и Аома, слушатели приобрели 300 экземпляров «Церковных песнопений». Кроме этих книжек, слушатели приобретали также книги Нового Завета и руководства Аля обмичения старообрядчества и сектанства» (Круповича 1914а: 99).

Архиепископ Иоанн (Смирнов) обычно присутствовац на всех курсах и сам выступам в качестве мектора. 28 января на курсах присутствовал священник англиканской церкви доктор Богословия Вальтер Фриер, приехавший из Англии с целью ознакомления с жизнью и обычаями Русской Православной церкви. Сам факт присутствия его на курсах говорит об их попумярности.

13 февраля на курсах присутствовах Полоцкий епархиальный миссионерский священник о. Киримл Зайц, приехавший специально Аля ознакомления с народно-миссионерскими курсами (Круповича 1914а: 176). По Аанным на 26 февраля в феврале количество слушателей Аостигло 438 человек. 
В марте занятия отличались особым оживлением. Успеху курсов способствовали доклады бывшего баптистского наставника Ф.А. Буцена, ставшего православным епархиальным миссионером, и перешедшего в православие католического священника о. Б.А. Ковалевского. Самое большое количество слушателей было 12 марта (свыше 500 человек).

Занятия в апреле и мае проходили обычным чередом. В этот периоА курсы посетили: старший цензор Ауховной цензуры архиманАрит Александр из Санкт-Петербурга и также священники из Сааремаа, Тукумса и т.А. (Круповича 1914a: 341). Это свидетельствовало о росте популярности курсов среАи православного духовенства.

12 мая скушатели курсов в знак благодарности за организацию курсов поднесли архиепископу Иоанну (Смирнову) икону св. Евангелиста Иоанна Богослова (Круповича 1914а: 508). Аетом занятия посещались также охотно, проходили один раз в неделю. КажАый день занятия посещало от 250 Ао 300 человек (Круповича 1914а: 341).

Начало Первой мировой войны прервало не только традицию народно-миссионерских курсов, но и приходскую жизнь Всехсвятской церкви в целом. Тем не менее к началу Первой мировой войны Всехсвятская церковь была крупным религиозно- просветительским центром Московского форштадта.

\section{Источники}

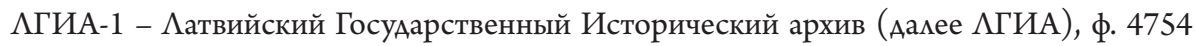
(Рижская Ауховная консистория), оп. 1, А. 185, ^. 14.

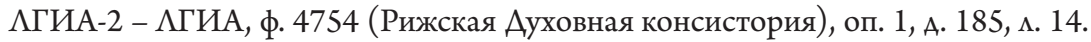

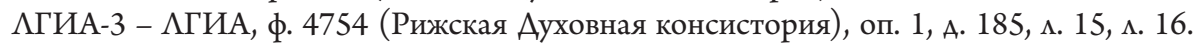

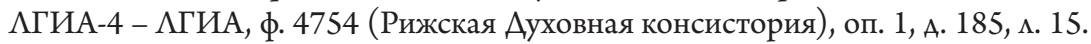
АГИА-5 - АГИА, ф. 4754 (Рижская Ауховная консистория), оп. 1, А. 188, м. 33. АГИА-6 - АГИА, ф. 4754 (Рижская Ауховная консистория), оп. 1, А. 188, м. 33. АГИА-7 - АГИА, ф. 4754 (Рижская Ауховная консистория), оп. 1, А. 191, м. 23. АГИА-8 - АГИА, ф. 4754 (Рижская Ауховная консистория), оп. 1, А. 197, ^. 6. $\Lambda$ ГИА-9 - АГИА, ф. 4754 (Рижская Ауховная консистория), оп. 1, А. 198, ^. 30. $\Lambda$ КИА-10 - АГИА, ф. 4754 (Рижская Ауховная консистория), оп. 1, А. 228, м. 42.

$\Lambda$ ГИА-11 - АГИА, ф. 7462 (Канцемярия епископа Рижского и Митавского), оп. 1, А. 1,

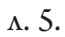

\section{Литература}

Вахрамеев, Г. (1912). К преАстоящему 100-летию Рижской Благовещенской церкви. Рижские епархиальные ведомости, 1 мая. С. 304.

Гаврилин, А.В. (2001). Строительство православных храмов на территории Аатвии до середины XIX века. В: Православие в Һатвии. Исторические очерки 3. Сборник научных статей под редакцией А.В. Гаврилина. Рига: Филокалия. С. 79-80, 86-88. Гамлер, К. (1884). Православные церкви в Риге. Рижский вестник. 27 октября. (1890). Епархиальная хроника. Рижские епархиальные ведомости, выпуск 8. С. 262. 
Краснянский, Г. (1890). Поучение по поводу открытия внебогослужебных чтений или собеседований во Всехсвятской церкви города Риги, сказанное 18 ноября 1890 года. Рижские епархиальные ведомости, выпуск 23. С. 723.

Краснянский, Г. (1891). Поучение по поводу освящения наАмогильного памятникачасовни на Всехсвятском кладбище города Риги. Рижские епархиальные ведомости, выпуск 23. С. 798.

Краснянский, Г. (1892). Поучение по поводу возобновления выбора чиенов Всехсвятского церковно-приходского попечительства в г. Риге, произнесенное 19 января 1892 года. Рижские епархиальные ведомости, выпуск 4. С. 152, 154.

Круповича, Э. (1888). Посещение церквей города Риги Преосвященным Арсением. Рижские епархиальные ведомости, выпуск 3.

Круповича,Э.(1894). Торжество освящения каменногодвухэтажного здания и открытия внёмцерковно-приходскойшколы. Рижскиеепархиальныеведомости, выпуск 4.С. 147.

Круповича, Э. (1913). Религиозно-нравственные беседы в г. Риге. Рижские епархиальные ведомости, выпуск 3. С. 88.

Круповича, Э. (1914а). Народно-миссионерские курсы в г. Риге. Рижские епархиальные ведомости, выпуск 4. С. 97-99, 176, 341, 508.

Круповича, Э. (1914b). Открытие православных народно-миссионерских курсов. Рижские епархиальные ведомости, выпуск 2. С. 53.

Круповича, Э. (2005). Рижская церковь Всех Святых как центр культуры Аатгальского предместья в 20-20-е годы XX века. Rusistica Latviensis 5. Slavica - 2015: filologijas pètējumi. Rīga: LU Akadēmiskais apgads. C. 201-207.

Gutzeit, W. (1868). Mittheilungen aus dem Gebiete der Geschichte Liv. - Ehst. - Kurlands. Riga: Nicolai Kymmels Buchhandlung. Band 11. S. 411.

\section{Rīgas Visu Svēto baznīcas draudzes dzīve līdz 1914. gadam}

Rīgas Visu Svēto baznīca atrodas bijušās Maskavas priekšpilsētas teritorijā. 1777. gadā kapsētas teritorijā tagadējo ielu - Katol̦u, Lielā kalna un Daugavpils ielas rajonā tika uzbūvēta kapliča, ko nosauca Visu Svēto vārdā, un tad arī kapsēta ieguva Visu Svēto kapsētas nosaukumu. Šo gadu var uzskatīt par Visu Svēto baznīcas vēstures sākumpunktu. 1812.-1814. gadā kapličas vietā tika uzcelta koka baznīca, kas piederēja Rīgas Marijas pasludināšanas baznīcas draudzei. 1852. gadā Visu Svēto draudze kḷuva par neatkarīgu draudzi. 19. gadsimta 80.-90. gados sākās jauns posms baznīcas arhitektūras ansambļa izveidē: tika uzcelta jauna akmens baznīcas èka (1884. g.) un draudzes skolas èka (1892. g.). 19. gadsimta otrajā pusē un 20. gadsimta sākumā Visu Svēto draudzē regulāri notika katķisma mācības, misionāru pārrunas un ārpusdievkalpojumu lasījumi. 1914. gadā draudzē tika atklāti misionāru kursi. Pirmā pasaules kara sākums pārtrauca Visu Svēto baznīcas draudzes dzivi, tomēr pirms tam Visu Svēto baznīcas draudze bija izveidojusies par nozīmīgu Maskavas priekšpilsētas reliǵijas un izglītỉbas centru.

\section{The All Saints Orthodox Parish of Riga until 1914}

The Riga's All Saints Church is located on the territory of the former so-called Moscow suburb (Maskavas forštate). In 1777, a chapel in the name of All Saints was built on the territory of the cemetery in the area of the present day Katolu, L. Kalna and Daugavpils streets, and the cemetery was named the All Saints. This date can be considered as the beginning of the history of the All Saints Church. In 
1812-1814, a wooden church was built instead of the chapel, and it was attributed to the Annunciation Church of Riga. In 1852, the Church of All Saints became an independent parish church. A new stage in the development of the architectural ensemble of the church began in $80 \mathrm{~s}-90 \mathrm{~s}$ of the $19^{\text {th }}$ century: the construction of a new stone church building was completed (1884), and the parish school was built (1892). By the beginning of the First World War, the All Saints Church was a major religiouseducational centre in the suburbs. 
DOI: http://doi.org/10.22364/ruslat.glp.06

\section{Валентина Борбунюк}

\section{«Сюжет для небольшого рассказа»: новелла И. Франко «Крыло сойки» в контексте драматургии А. Чехова}

В статье исследована поэтика новемлы И. Франко «Крыло сойки» ${ }^{1}(1905)$ в контексте Араматургии А. Чехова. Проанализировано сложное взаимодействие художественных миров И. Франко и А. Чехова в еАином культурном процессе смены эстетических парадигм на рубеже XIX-XX вв. Показано, что с А. Чеховым И. Франко сближает выАвижение на первый план внутренних переживаний героев, использование поэтических мотивов и символики, трактовка характера центрацьного персонажа как сложного единства противостоящих начац, философичность открытых финалов, стремление к жанровому и родовому синтезу.

Ключевые слова: А. Чехов, Араматургия, И. Франко, контекст, мотив, символ

И. Франко, родившийся в 1856 году, и А. Чехов, родившийся в 1860 году, были современниками. О мичном знакомстве Авух гениев украинской и русской культур прямых сведений не сохранилось. ОАнако, благодаря взаимному интересу к митературной и культурной жизни, простиравшемуся Аалеко за рамки географических и политических границ, их разАелявших, а также непосреАственному взаимодействию в митературно-изАательской Аеятельности, они оказались «вписанными» в общий Аитературный процесс конца XIX - начала XX века.

Тема «А. Чехов и И. Франко» Ао сих пор не становикась предметом специального научного изучения. В чеховедении она мишь пунктирно обозначена в исследованиях «А. Чехов и Украина» (Звиняцковский 1985). В свою очереАь, немногочисленные исследования на тему «И. Франко и русская митература» (Пархоменко 1954; Фризман 2017), вводя И. Франко в широкий круг писателей, начиная от А. Пушкина, Н. Гоголя, Н. Некрасова, И. Тургенева, М. Салтыкова-Щедрина, $\Lambda$. Толстого, Г. Успенского и заканчивая Максимом Горьким, имя А. Чехова не упоминают Ааже вскользь. Новейших исследований на эти темы, к сожалению, не существует. Усматривая в самом факте парамельной творческой деятельности И. Франко и А. Чехова определённую знаменательность, мы ставим переА собой цемь осмыслить сложное взаимодействие их художественных миров в еАином культурном процессе смены эстетических парадигм на рубеже XIX-XX веков.

1 I. Франко «Сойчине крико». 
Объектом исследования станут новемла И. Франко «Крыло сойки» и пьеса А. Чехова «Чайка».

Сопоставление этих Авух разножанровых произведений продиктовано следующими соображениями. Уже Аавно стала аксиомой мысль, что «ни оАин из выАающихся писателей и Аеятелей искусства 80-90-х годов и начама XX века не прошем мимо Чехова» (А.П. Чехов в воспоминаниях современников 1960: 4). И. Франко был хорошо знаком с чеховским творчеством. Напомним, что украинский писатель входия в состав реАкомлегии мьвовского журнала «Аитературно-научный вестник», в котором публиковамись переводы рассказов А. Чехова. И. Франко-поэту могла импонировать такая особенность чеховского творчества, как миризация эпоса и Арамы, «пиавность жанровых границ» (выражение Э. Полоцкой) в произведениях писатемя.

Написанная в 1905 году новемла «Крымо сойки» признана современными митературоведами удачным экспериментом миризованной прозы, произведением, которое также выросло «на перекрёстке размичных митературных родов и жанров» [зАесь и Аалее перевод мой. - В. Б.] (Аенисюк 1968: 99). Вместе с тем эта новемла относится к числу несправеАливо обойАённых как украинской, так и зарубежной критикой (Боярська 2008). ОАной из актуальных проблем современного франковедения является изучение интертекстуацьных связей творчества писателя (Аегкий 2008: 734). Представляется вполне закономерным интерпретировать новеллу, имеющую орнитологическое название и тяготеющую к Араматургическому роду, в контексте чеховского творчества. «Чайка» А. Чехова «стала выполнять роль претекста по отношению к послеАующим произведениям почти сразу и выполняет ее уже более столетия» (Катаев 2001: 267). Косвенным подтвержАением «миграции» «Чайки» в художественное сознание украинских писателей ещё при жизни автора является рассказ с одноименным названием, опубликованный под псевдонимом «Наталка Полтавка» в « $\Lambda$ итературно-научном вестнике» в 1899 году в том же номере, что и чеховские рассказы. В украинской версии Чайкой называет себя героиня в письме к своей благодетемьнице, рассказывая о том, как вымаливала прощение у мужа за несовершённый проступок: «Я как та чайка жамобно кигикама и силилась, чтобы отвести его подальше от моего Аитяти! Аумаха затуманить его, отваАить моим криком!» (Наталка Полтавка 1899: 252). И благодетельница, не имея возможности помочь Аевушке, констатирует: «БеАная чайка!» (Наталка Полтавка 1899: 253), предопреАеляя вслеА за А. Чеховым загубленную «от нечего Аемать» судьбу своей героини.

Соотнося наиболее значимые жизненные и творческие вехи в жизни Аеси Украинки и А. Чехова, С. Романов справеАливо указац, что оАной из «интерпретативных стратегий» в попытках научно-критического сопоставления художественных миров «самодостаточных писателей» явцяется «Аискурс взаимодополнения» (Романов 2011). В результате могут быть обнаружены интересные парамели, выявлены не только черты сходства, но 
и отличия, обусловленные этнической принаАлежностью и национальной самоидентификацией писателей, их общественно-политической среАой и культурным окружением, художественными влияниями и инАивиАуально-стилистическими особенностями творчества. Полагаем, что подобный подход может оказаться продуктивным и в отношении И. Франко и А. Чехова, что в итоге позволит обнаружить межтекстовые взаимодействия, неучтённые митературные контакты, преАложить новые интерпретации траАиционных текстов, обновмяющие их смысл.

Опубликованная в 1905 году, через год после смерти А. Чехова, новемла «Крыло сойки» прочитывается, на наш взгляА, как своего рода Аань памяти И. Франко великому современнику, завершая их заочное знакомство. ПреАставление об этом знакомстве, к сожалению, непомное (из насчитывающего более шести тысяч писем эпистолярного наследия И. Франко сохранилось мишь около 900 автографов писем и несколько Аесятков публикаций), Аают письма писателя, в которых первое упоминание имени А. Чехова относится к 1899 году. В июльском письме к М. Грушевскому читаем: «На н[оме]р IX Ааю в печать в разделе $\mathrm{A}<\ldots>$ большой кусок Чехова $>$ (Франко 1986: 135-136). И месяц спустя, когАа номер практически свёрстан: «Содержание $<\ldots>$ такое. В бемлетристической части пошио всё то, что мы составмяли, а именно, Коваленко, пять очерков Яцкова, Ава рассказа Кравченко, “Наш альбом" (стихотворения Гринченко, Попович-Боярской и В.), часть “Бар-Кохби”, “Библис” Аьюиса, Финияндец и остальное Чехова (ещё состав-

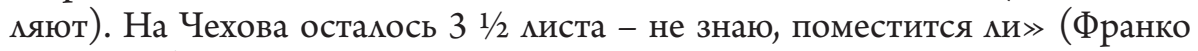
1986: 137). ОАнако А. Чехов вошёл в круг чтения И. Франко горазАо раньше. Косвенным подтверждением этого явцяется, например, письмо Аеси Украинки от 21 октября 1898 года. Писательница просит И. Франко отрецензировать книгу начинающего автора и Аля убедительности апемлирует к авторитету А. Чехова: «Автор этой книжки, мой товарищ, молодой ещё, и это первый его труА, который появился в печати. В Киеве эти рассказы произвели впечатление, их ставили рядом с "Мужиками” Чехова, Аа и судьба их была сродни тех же “Мужиков": оАни чрезмерно хвалили, Аругие чрезмерно хулили» (Украинка Аеся 1979: 73). Прямых свидетельств об отношении А. Чехова к творчеству И. Франко не сохранилось. ОАнако факт размещения в оАном и том же номере «Аитературно-научного вестника» чеховских рассказов и мирических произведений И. Франко, позволяет преАположить, что А. Чехов вполне мог ознакомиться со всеми публикациями этого журнаца.

Обратимся к тексту новемлы «Крыло сойки». ГАавную героиню манят «миры, полные невыразимых наслаждений, сплошной свободы, пымкой мюбви» (Франко 1990: 448). Она убегает с молодым практикантом, оставив в неведении как родного отца, так и мюбимого человека, которого позже и обвинит в своём проступке. Не вынеся разлуки, отец героини умирает, а мюбимый человек становится отшельником. Спустя три гоАа после череды злоключений, «блудная Аочь» возвращается в родные края. 
В современном франковедении существует мнение, что внешняя схема сюжетной комлизии (столкновение представителя города, цивилизованного человека, и человека природного, натурального) напоминает схему многих произведений, в частности, «Олесю» А. Куприна, «Араму на охоте» А. Чехова, «Природу» О. Кобылянской. ОАнако, в отличие от вышеупомянутых произвеАений, гАе природный чемовек терпит поражение, в «Крыце сойки» именно этот человек выдерживает испытания судьбы и находит в себе силы выжить и вернуться, чтобы начать всё сначала (Боярська 2008: 781). Не оспаривая преАложенные митературные парамлели, заметим, что сюжет новемлы И. Франко у зрителя, знакомого с чеховским театром, вызывает ассоциации с «Чайкой», прежАе всего с «сюжетом Аля небольшого рассказа», который по ходу Аействия пьесы заносит в свою записную книжку митератор Тригорин: «на берегу озера с детства живёт молодая девушка <...> Аюбит озеро, как чайка, и счастлива, и свободна, как чайка. Но случайно пришёл человек, увидел и от нечего Аелать погубил её, как вот эту чайку» (Чехов 1978а: 31-32). Этот «сюжет» в «Чайке» современные исследователи приводят в качестве примера того, как фрагмент может заслонить собой целое (Головачёва 2001). ОАной из первых вариаций тригоринского сюжета стало стихотворение Е. Буланиной «ПоА впечатлением “Чайки” Чехова» (1901). Положенное на музыку композитором Е. Жураковским, оно бытовало в начале XX века под заголовком «Чайка», «состязаясь с чеховским текстом» (Головачёва 2001: 20). Кроме того, микросюжет о девушке-чайке тяготеет к массовой бемлетристике.

Рассматривая «Крыло сойки» сквозь призму чеховской Араматургии, есть все основания преАполагать, что в интерпретации И. Франко этот белметристический микросюжет также заслоняет собой целое, то есть всю чеховскую пьесу. ОАнако многие из перечисленных самим А. Чеховым составмяющих «Чайки» («КомеАия, три женских роли, шесть мужских, четыре акта, пейзаж (виА на озеро), много разговоров о митературе, мало Аействия,

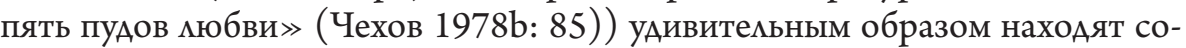
ответствия в новемле.

Естественно, что упомянутые А. Чеховым составмяющие в новемле И. Франко претерпели изменения: женские роли фактически свеАены к оАной (хотя Ао побега, во время скитаний и после своего возвращения переА нами одна и та же героиня, но в трёх ипостасях), а мужские, наоборот, увемичены Ао восьми тех, с чьей помощью героиня губила сама себя, и отАемьно стоящей роли по-настоящему мюбящего её героя ${ }^{2}$. Чеховское определение жанра пьесы также находит преломиение в новемле: слово «комедия» и его производные пронизывают весь текст насквозь, явцяясь оАним из кАю-



2 В этой связи интересное решение нашёл режиссёр харьковского театра «P.S его пьесе по новемле И. Франко задействованы трое актёров, при этом один из них играет по очереди всех восьмерых «погубителей» Сойки. 
Жанровые границы «Крыла сойки» Аостаточно размыты и определяются современными исследователи как «лирическая Арама в прозе», «произвеАение, интересное синтезом эпоса, мирики и Арамы» (Аенисюк 1968).

Герои новемлы, в отличие от чеховских, не связаны ни с театром, ни с митературой, однако их речь изобикует театральными метафорами, а сама новемла - театральными приёмами. ГАавный герой, чей образ жизни предопределяется уже подзаголовком новемлы - «Из записок нелюАима» - так характеризует себя: «Никто не подозревает в этом сухом формалисте и реалисте сибарита Ауха, художника, который ценит Аишь оАно искусство Аля искусства - умение жить (Франко 1990: 429). В новеме события происходят в канун Нового года, и герой намерен новогоАний вечер провести/ прожить строго по сценарию, им самим же и составленному, Аопуская, оАнако, и возможность импровизаций. Интерьер кабинета сроАни ремарке в пьесе: «Со стен гмядят <...> превосходные портреты великих мастеров в искусстве жизни: Гёте, Эмерсона, Рескина. На полках стоят <.. > мюбимые книги в красивых переплётах. На подставке в углу мраморная копия старинной статуи $\langle\ldots>$, и всюду на столиках цветы $<\ldots>$. На письменном столе портфель с <.. > Аневником $>$ (Франко 1990: 429).

Массино, герой И. Франко, чей образ ассоциируется и с Константином Треплевым, безналёжно влюблённым в Нину, и с Тригориным, свою теперешнюю жизнь сравнивает с амлеей: «Моя жизнь - как прямая, широкая, удобная, красивыми Аеревьями обсаженная аммея, которая ведёт... Тьфу! Что это я? С какой стати сегодня вспоминать о том, что красуется в конце этой аммеи, в конце мюбой жизненной Аороги, будь это прямая амлея ими крутая, каменистая и ухабистая тропинка? Оставим это, нас оно не минует, а своей охотой мететь туАа нет нужАы» (Франко 1990: 432). А^мея - оАин из сквозных мотивов чеховской Араматургии. Она в кюбой момент может быть погублена кем-то, как и жизнь. Наташа, героиня пьесы «Три сестры», став полновластной владелицей, замечает: «Велю прежде всего срубить эту еловую аммею, потом вот этот клён. По вечерам он такой страшный, некрасивый... » (Чехов 1978а: 186). Героиня И. Франко своим проступком также губит/рубит символическую аммею жизни мюбимого человека.

ОАнако составленный героем-отшельником сценарий новогоднего вечера претерпевает существенные трансформации после того, как он получает письмо со странной подписью: «Твоя Сойка»: «Что это значит? Никакой Сойки - боже мой! И крыио сойки в письме!... Аа неужто? Неужто она, та, которую я вот уже три гоАа считаю умершей? <..> В послеАние Ани нашей Аружбы она мюбила называть себя сойкой и постоянно Аразнила меня той сойкой, которая гнезАилась наА самым моим окном, пока она не убила её. Неужели это крыло той самой сойки?..» (Франко 1990: 434). Эти строки, на наш взгляА, открыто апемлируют к А. Чехову. Сравним у А. Чехова. Треплев рассказывает о письмах Нины: «Она подписывалась Чайкой. В “Русалке” мельник говорит, что он ворон, так она в письмах все повторяма, что она чайка. Теперь она зАесь» (Чехов 1978а: 50). Во время 
их послеАнего свиАания эти слова рефреном прозвучат уже из уст самой Нины: «Я так утомилась! ОтАохнуть бы ... отАохнуть! (Поднимает голову.) Я - чайка... Не то. Я - актриса. Ну, Аа! <...> Вы не понимаете этого состояния, когда чувствуешь, что играешь ужасно. Я - чайка. Нет, не то... Помните, вы подстрелили чайку? Случайно пришёл человек, увидек и от нечего Аелать погубим... Сюжет Аля небомьшого рассказа... Это не то... » (Чехов 1978а: 58). Заметим, что по отношению к «Чайке» персонажи новеммы И. Франко полигенетичны: герой напоминает одновременно и Треплева, и Тригорина, а героиня в своих поступках тяготеет и к Нине, и к Треплеву.

ИАеальные образы возмюбленных живут в сознании как Треплева, так и Массино. ОАнако, в отмичие от чеховского героя, рассказчик И. Франко постарался избавиться от воспоминаний. Их отношения с Сойкой, как выяснится из письма позже, развивались по тщательно спланированному ею сценарию. Героиня И. Франко, подобно Нине, также играха, сценой Амя Сойки была сама жизнь. Театральные приёмы и эффекты она продолжает использовать и в эпистолярном общении. В письмо «сойка из Порт-Артура», как теперь именует свою возмюбленную Массино, вкладывает крыло птицы, которую когАа-то сама же и застрелика. Этот символический жест сопровожАается подробными воспоминаниями. Как виАим, в героине сочетаются черты не только «природной натуры», но и «роковой женщины», способной погубить/убить свою «соперницу», символом которой Аля неё выступает сойка. В «Чайке» невинную птицу «Аля нагляАности» убивает Треплев. Грозясь таким же образом убить самого себя, он пытается вернуть ускользающую Нинину мюбовь. ОАнако ключевым моментом в этой возникшей чеховской аммюзии явмяется принципиально иное разрешение схожей эстетической комлизии - Аальнейшей судьбы убитой птицы. В чеховской пьесе, как выяснится в финале, по просьбе Тригорина из убитой чайки слелают чучело, в новемле И. Франко - сойку сначала «оплачут», а потом зажарят и, уже смеясь, съеАят на обеА, сохранив при этом крылья, подобно сорванным цветам, межАу книжных страниц. В подобной художественной семантике образа убитой птицы обнаруживаются постмодернистские черты художественного миромоделирования.

Исследователи творчества И. Франко указывают, что писатель с удовольствием пользовался созАанными мировой митературой приёмами, оАнако никогаа не был схематичным (Аенисюк 1968: 103). Образом-символом становится в Аанном случае не вся птица, а её часть - крыло. Современные исследователи трактуют этот образ Аостаточно широко: «сквозной образ-симво , образ-вещь, своеобразный мейтмотив», «фокус, что вбирает в себя всю богатую палитру, это эпицентр психологических катаклизмов, завязка, кульминация и развязка, а оАновременно символ большого чувства» (Аенисюк 1968: 102, 103). При этом чеховские коннотации отсутствуют. ОАнако, на наш взгляА, они настолько явственны, что не могут не задавать один из главных векторов анамиза и интерпретации. В новемле И. Франко, как и в пьесе А. Чехова, птица, ассоциируясь с разцичными героями, 
символизирует и свободу, и Ауховный взмёт, и безвременную гибель, и неосуществлённую мечту. При этом, если у А. Чехова мотивировки поступков не Ао конца прояснены, то И. Франко, наоборот, мотивацию «договаривает». На эту особенность авторских «подсказок» (хотя и в Аругом контексте) обратил внимание Ю. Безхутрый: «<..> в отмичие от “развитого” модернизма, который фокусируется на неявных, подтекстовых значениях сюжетных ходов, побужАая читателя к самостоятельному поиску смысла изображённого, И. Франко не оставцяет реципиента наеАине с изображёнными событиями, а разными способами помогает ему разобраться в значении перипетий, разъясняет подтекстовые намёки» (Безхутрий 2008: 528).

Родство с А. Чеховым ощущается в оАной из кучших и, насколько нам известно, первой из сценических интерпретаций новемлы И. Франко на современной украинской сцене - спектакле с одноименным названием «Крыло сойки» харьковского театра «P.S.» ${ }^{3}$ (реж. С. Пасичник). Явной режиссёрской отсылкой к чеховской «Чайке» в харьковской постановке является прозвучавший в финаце за сценой выстрел, которого нет в тексте новемлы. Во многом благодаря опыту чеховского театра, как нам кажется, режиссёру удалось реализовать потенциальную сценичность новемлы, на которую исследователи указали ещё полвека тому назаА, заметив, что «Крыло сойки», можно поставить на сцене почти без изменений текста (Аенисюк 1968: 100).

Проведенный анализ подтвержАает сформулированный в послеАнее Аесятилетие в современном франковедении тезис о том, что творчество И. Франко, в частности, его проза 1900-х годов, пребывала в процессе перехода от художественной парадигмы митературы XIX века к новой, модернистской по своей сути парАигме ХХ века. С А. Чеховым И. Франко сближает выдвижение на первый план внутренних переживаний героев, использование поэтических мотивов и символики, трактовка характера центрального персонажа как сложного единства противостоящих начал, философичность открытых финалов, стремление к жанровому и родовому синтезу. При этом Аиалогические минии связывают А. Чехова и И. Франко не как мастера и последователя, а как равновеликих современников, в чьей художественной картине мира отразилось кризисное состояние человека рубежа веков.

\section{Литература}

А. П. Чехов в воспоминаниях современников (1960). Котова, А.К. / предисловие. Москва: ХуА. митература. $834 \mathrm{c}$.

Безхутрий, Ю. (2008). Мала проза Івана Франка 1900-х років у контексті художньої парадигми перехідної культурної епохи: модель світу і модемь мюАини. В: Іван Франко: дух, наука, думка, воля. ьвів: Видавничий центр $\Lambda$ ьвівського національного університету імені Івана Франка, Т. 1. С. 526-533.

3 Следующим бым Киевский академический театр на Подоле. 
Боярська, $\Lambda$. (2008). «Сойчине кримо» Івана Франка: інтеграція новітніх європейських мітературних пошуків. В: Іван Франко: дух, наука, думка, воля. центр Аьвівського національного університету імені Івана Франка, Т. 1. С. 776-786.

Головачёва, А.Г. (2001). «Сюжет Аля небольшого рассказа». В: Чеховиана. Полет «Чайки». Катаев, В.Б. / реА. Москва: Наука. С. 19-35.

Аенисюк, І.О. (1968). Про родово-видові особливості «Сойчиного крила». В: Українське літературознавство, вип. III. Іван Франко. Статті й матеріали. Аьвів: ВиА-во Аьвівського університету. С. 98-103.

Звиняцковский, В.А. (1985). Чехов и Украина (По страницам нового издания). Радуга. № 1. С. 136-140.

Катаев, В.Б. (2001). Чайка - Цапмя - Ворона (Из митературной орнитологии XX века). В: Чеховиана. Полет «Чайки». Катаев, В.Б. / реА. Москва: Наука. С. 267-276.

Аегкий, М. (2008). Неосягнені горизонти Франкової прози (актуальні проблеми наукових досліАжень). В: Іван Франко: дух, наука, думка, воля. Аьвів: ВиАавничий центр Аьвівського національного університету імені Івана Франка, Т. 1. С. 725-727.

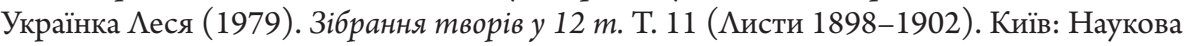
Аумка. 478 с.

Пархоменко, М. (1954). Иван Франко и русскал митература. Москва: Гослитизаат. $244 \mathrm{c}$.

Полтавка Наталка (1899). Чайка. Аітературно-науковий вістник, випуск XIX. C. 241-253.

Романов, С. (2011). Аеся Українка - Антон Чехов: психологія, Аоля покликання. Слово i час. № 2. С. 18-37.

Франко, І. (1986). Зібрання творів у 50 mm. : Аисти тт. 48-50. Т. 50 (Аисти 1895-1916). Київ: Наукова Аумка. 704 с.

Франко, И. (1990). Крыио сойки (Из записок нелюдима). В: Франко И. Собр. соч. : В 3 m. Т. 2 : Рассказы. Турганова, Б. / пер. с укр. Москва: ХуА. митература. С. 426-468.

Фризман, А.Г. (2017). Аев Толстой в восприятии Ивана Франко. Collegium. № 26. Аоступен на 07.08.2018: http://old.burago.com.ua/ru/zhurnaly/mezhdunarodnyjnauchno-populyarnyj-zhurnal-collegium/collegium-26-2017

Чехов, А.П. (1978а). Полн. собр. соч. и писем: в 30 m. : Соч. : в 18 т. Т. 12-13. Москва: Наука.

Чехов, А.П. (1978b). Полн. собр. соч. и писем: в 30 m. : Письма. : в 12 т. Т. 6. Письма, Январь 1895 - май 1897. Москва: Наука. 775 с.

\section{"Sižets nelielam stāstam": I. Franko novele "Sịla spārns" A. Čehova dramaturǵijas kontekstā}

Rakstā aplūkota Ivana Franko noveles "Sị̂la spārns" (1905) poētika Antona Čehova dramaturgijas kontekstā. I. Franko un A. Čehova mākslinieciskās pasaules mijiedarbe analizēta no estētisko paradigmu (19.-20. gs.) maiņas skatpunkta. Abus rakstniekus vieno viņu varoņi, kuru iekšējais pārdzīvojums izvirzìts pirmajā plānā. Gan I. Franko, gan A. Čehovs izmanto līdzīgus poētiskus motīvus un simboliku, viṇi līdzīgi traktē savu centrālo personāžu pretrunīgo raksturu. Abiem darbiem ir atvērts fināls, un abi autori izmanto žanru sintēzi. 


\section{"Plot for a Short Story": I. Franko's short story “The Jay's Wing" in the context of A. Chekhov's dramaturgy}

The article is devised for the analysis of poetics of I. Franko's short story "The Jay's Wing" in the context of Chekhov's dramaturgy. The complex interaction of the artistic worlds of I. Franko and A. Chekhov is considered against the backdrop of an aesthetic paradigm change at the turn of the 19th and 20th centuries by applying comparative historical, typological and intertextual methods of analysis. The affinity between A. Chekhov and I. Franko is highlighted by fore fronting the inner experiences of the characters, by the use of poetic motifs and symbols, the interpretation of inherent complex unity of opposing forces shaping major characters, the philosophy of open ending, while aiming at genre and generic synthesis. The conducted study allows to speak about the generality of poetics and the problems of I. Franko's short story and A. Chekhov's dramaturgy, in particular of "The Seagull" play. Dialogic lines link A. Chekhov and I. Franko not as a master and follower, but as equal modern contemporaries, whose artistic worldview has reflected the turn of the century crisis of man. 
DOI: http://doi.org/10.22364/ruslat.glp.07

\section{Полина Поберезкина}

\section{Ю. Балтрушайтис в печати Украины 1910-20-х гг.}

Юргис Балтрушайтис вошем в историю Украины как митовский Аипломат, оАнако ранее он стал известен как русский поэт. В статье Аополнена его персональная библиография публикациями в киевских антологиях и рецензией Николая Брандта, проанализирован первый украинский перевод его стихов, выполненный Мыколой Хомичевским, и приведены свидетельства рецепции его литературного творчества по материалам местной периодики и архивных фондов.

Ключевые слова: Ю. Балтрушайтис, Н. Брандт, М. Хомичевский, украинскоАитовские отношения, русско-украинские митературные взаимосвязи, перевоА

Юргис Балтрушайтис вошем в историю Украины как митовский Аипломат: 14 феврамя 1921 г. в Москве бым подписан Мирный договор межАу Украинской Социалистической Советской Республикой и Аитовской Аемократической Республикой (Павленко 2004: 428). Уполномоченными со стороны $\Lambda$ АР были Ю. Балтрушайтис, И. Ванагас-Симонайтис, Р. Иоделис и К. Свилас, а от УССР - Ф. Кон и Ю. Коцюбинский. Основному Аоговору сопутствовали: Соглашение о порядке оптации митовского гражАанства от 28 января 1921 г., подписанное вышеперечисленными мицами (за исключением Ф. Кона), и Аополнительный договор от 5 апреля 1922 г., подписанный в Харькове В. Мошинским и Я. Истоминым. Тексты указанных документов перепечатывались на украинском и русском языках (Аополнительный Аоговор 1922; Бемов и Ар. 1959: 517-522; Забігайло, Михайловський, Хміль 1966: 235-246), но при этом частотность упоминаний Балтрушайтиса в официальной хронике неочевиАна. Так, например, в кратком сообщении «Мир с Аитвой», опубликованном 18 феврамя 1921 г. в харьковской газете «Известия ВУЦИК» (Мир з Аитвою 1921: 1), поименно названы только представители Украины.

ОАнако еще раньше Балтрушайтис приобрел известность как русский поэт. Знакомство украинских читателей с его творчеством осуществлялось с конца 1900-х гг. благодаря публикациям в киевских сборниках «ЧтецАекламатор ${ }^{1}$. В 1909 г. появимась поАготовленная реАактором и перевоА-

1 К сожалению, из-за относительной труднодоступности этих изАаний мы не можем гарантировать полноту их охвата, однако преАставценная выборка кажется репрезентативной. 
чиком Федором Михайловичем Самоненко ${ }^{2}$ (1883-1938) и поэтом ВлаАимиром Юрьевичем Эльснером (1886-1964) «Антология современной поэзии», в которую вошии стихотворения Балтрушайтиса «Мой храм» («Мой светлый храм - в безбрежности...»), «Славься, утро» («Ты кажАый Аень, жемчужно-золотое...»), «Аетские страхи» («В нашем Аоме нет затишья...»), «Утренние песни» («Просияла заря переА шествием Аня... ») и «Маятник» («В тягостном сумраке ночи немой...»), а также отрывки из его переводов «Мертвого города» Г. А’Аннунцио, «Виктории» К. Гамсуна и перевоА «Новемлы» О. Гансона (Самоненко, Эльснер 1909: 544-548, 265-270, 308-318). В следующем издании этого тома в 1912 г. напечатаны уже 8 стихотворений Бамтрушайтиса: «Вся мысль моя - тоска по тайне звезАной...», «Мой храм» («Мой светлый храм в безбрежности...»), «Аккорды» («Как раздумье в сердце мирном...»), «Черное озеро» («Из храма гор, из сонной мглы месной...»), «Аорога» («Вьется пыиьная дорога...»), «Аетские страхи» («В нашем Аоме нет затишья...»), «Утренние песни» («Просияла заря переА шествием Аня... »), «Маятник» («В тягостном сумраке ночи немой... »), - а переводы дополнены фрагментом «Сонаты призраков» А. Стриндберга (Самоненко 1912: 623-627, 318-323, 353-364, 379-390). Николай Гумилев писал: «Киевская “Антология” бесспорно мучшее имеющееся у нас руковоАство Аля ознакомления с той полосой русской поэзии, которая царила в эпоху “Весов” » (Гумимев 1913: 71). Парамлемьно этому в 1911 г. вышии Ава тома, составленных соответственно Я.С. Аробинским и С.В. Каратыгиным и включавших Аругие произведения Балтрушайтиса: «Прибой» («Шумит, гремит Аневное море...»), «В горах» («Простор! РазАолье Аикое!..»), «Аевичьи грезы» («Аевичьи грезы - как тучи рассветные... $), \ll В$ месу» («Тишь... Безмолвие месное... »), «Великий час! Аучистая заря... » (Аробинский 1911: 136-138) и «Сон» («Мне снилось: я межал уже в земле сырой...») (Каратыгин 1911: 403). Продолжался выпуск прежних серий, и в 1912 г. увидели свет 6-е изАание второго тома и 2-е изАание третьего со стихами и переводами митовского поэта: «ОАиночество» («В кругу мюАей - я среАь чужих... »), «Миг свободы» («НаА угрюмою темницею, наА оградой глухой...»), «Колокол» («Зычно и скорбно, удар за ударом...»), «Есть среАи грез оАиноких оАна...», «На пороге ночи» («В вечерней мгле теряется земля... ») (Чтец-Аекламатор 19126: 92, 159-160, 293, 391-392, 447) и «Кочевники» («Качнулись последние стены...»), «Ноктюрн» («Час полночный... Миг неясный... »), «Из “Ажиоконды” » Г. А’Аннунцио, «Новемла» О. Гансона (Чтец-Аекламатор 1912а: 153-154, 389-391, 447-451). В 3-м изАании третьего тома, вышеАшем гоА спустя, были добавлены еще 2 стихотворения: «Ноктюрн» («Час полночный... Миг неясный...»), «Черное озеро» («Из храма гор, из сонной мглы

2 Письмо Балтрушайтиса к нему от 6 марта 1909 г.: РГААИ. Ф. 1284. Оп. 1. ЕА. хр. 20. Искренне благодарим за консультации Юлию Снежко. 
месной...»), «Приближенье» («Угрюмы скац решенные отвесы...»), «Кочевники» («Качнулись последние стены...»), «Новемла» О. Гансона, «Из “Ажиоконды” \. А’Аннунцио (Чтец-декиаматор 1913: 42-43, 95-96, 262, 361-362, 525-529, 532-534).

ОАнако наибольшая по объему киевская публикация поэзии Балтрушайтиса не связана с многочисленными сборниками издательства Самоненко. «В 1914 году, в первые недели Мировой войны, в Киеве вышиа книга “Волны вечности в русской художественной митературе" - антология или хрестоматия стихов и прозы (по большей части в отрывках) на библейские темы. <...> "Волны вечности” сопровождал некоторый привкус загадочности, поскольку книга, последовательно называя авторов собранных в ней стихов и прозы, утаивала имя составителя и автора предисловия. Анонимность тем более уАивительная, что преАисловие было написано от первого мица. ОАнако Аля киевмян не было тайной, что “Вомны вечности” составмены и изданы Петром Павловичем Куарявцевым» (1868-1940), профессором Киевской Ауховной академии и одним из основателей Киевского религиозно-философского общества, под маркой которого увидела свет антология (Петровский 2008: 93-95). Произведения от XVIII до начала XX в. группировались по тематическим рубрикам, а Аитературный горизонт составителя был ограничен поэзией символизма (см. Рогожин 1958: 85-90). В сборнике перепечатаны тексты 12 стихотворений Балтрушайтиса: «Ночью» («Чутко спят тополя... Онемели поля...»), «Аккорды» (фрагмент «Серым покрывалом...»), «Вечерняя песня» («Входит поА сирую кровлю...»), «Мой храм» («Мой светлый храм - в безбрежности...»), «Отчизна» («Я родился в Аалекой стране... »), «ПреАчувствие» («Мне чуАятся Аали ночные...»), «Аорога» («Вьется пыльная Аорога...»), «Вечер» («Вечернее зарево меркнет, скудеет...»), «Вечерняя песня» («В вечерний час, в глухую пору...»), «А^ьпийский пастух...» («По высям снегами ... »), «Комоком» («Зычно и скорбно, удар за ударом... ») и «Пасхальный звон» («Арогнул в мире звон пасхамьный...») (Волны вечности 1914: 12, 19, 20, 31, 36, 37, 53, 55, 56, 72, 192, 359).

Заметим, что стихи в антологиях в большинстве своем не повторялись, и читатели, не видевшие столичной периодики и поэтических книг Балтрушайтиса, все же могли получить какое-то преАставление о его творчестве. Аебютный же его сборник быи отрецензирован в первом номере киевского журнала «Аукоморье», вышеАшем в начале октября 1911 г. (правАа, с нелепой опечаткой «темные» вместо «земных» ступеней). Поскольку Аанный отзыв не упомянут в библиографиях поэта (Гречишкин 1989: 146-148; ГАухова 2010: 129-136), приведем его полностью:

«За последнее время развился весьма странный метоА оценки некоторых писателей. Не обращая внимания на мичное, неотъемлемое привношение себя в стихийную ширь поэтических образов и настроений - заявмяют: “пишет под такого-то”. Это большая обида. Ибо 
можно находиться ПоА возАействием, ПоА вАиянием круПного художника слова и еще неуверенным резцом чеканить уже мелькнувшую в чужом созАании минию, но все это не Аолжно Аавать права заявить, что Аух человеческий, свободный в искании своем, поАлаживается поА определившийся вкус, старается ограничить проявления стихийного заранее намеченным пределом. Говорить так - значит не иметь в самом себе свободного доступа к вечным “Матерям”. И потому, говоря о поэзии Ю. Балтрушайтиса, я вынужАен отвергнуть пристегнутый к нему эпитет - современного Тютчева. Ибо не в темах и не в сходных настроениях суть - а в глубоком ритме духа - как бы в подводном течении “я” под видимой поверхностью вопиощаемых вещей. Тютчев, этот вемичайший прозорливец пейзажа и космоса, вникающий в самые недра посюстороннего - никогАа не бывает картинным. Он психолог живописи, его пейзажи: говор и деянье космических сил - сама природа. Она не заманивает красочными аксессуарами, переА ними стоишь в благоговейном молчании, ибо из самых вещей вытекает сила изобразительная и не поэт внедряет в нее свое я, но она сама заполняет его Аушу и творчество. Балтрушайтис хочет быть космичным и стихийным, но не будучи ни тем, ни Аругим, прикрашивает, наряжает безбрежное в пестрые, красочные платья. Но это не шумиха риторики. Среди образов Ю. Балтрушайтиса многие, бесспорно, Аостигают высокой красоты. И только когАа хмурый дух поэта пытается охватить необъятное, когАа земные руки посягают на небесные цветы, становится больно, ибо в этом большое кощунство. Возьмем Аля примера стихи “Ночью”. “Чутко спят тополя, онемели поля, раскрывается ночь бесконечная...” Веет ширью и тишиной! “ЗвезА исполнен простор, в их мучистый убор наряжается бездна предвечная”. (Это срыв, это безвкусица...) Точно актриса преА тем, чтобы выйти на эстраАу... Но если попытки изобразить космос кончаются неудачно у этого поэта - он Аолжен быть признан мучшим изобразителем человеческого Ауха, покинутого на самого себя, тоскующего у железных врат тайны... И зАесь, Аействительно, Балтрушайтис никому не уступит, разве Ф. Сологубу. Вот гАе он сам - каким ему велено быть свыше. Я упомянул о Ф. Сологубе только с некоторой оговоркой - ибо если он и певец оАиночества и томменья - то это происхоАит от пресыщения внешним миром, от скуки среАи серых, нудных мюАишек. И нет зАесь упоминаний о полетах в высь: за чертою стоять и ворожить - это исканье забвенья, где умиряется жажАа Аел, жажда мятежа рокоборца. Не то у Балтрушайтиса. Он еще молится, тоскующий невольник, свободе Аоли кочевой, еще поникает трепетная тень с молитвенным вопросом. А где есть молитва, там и светлая привязанность к бытию. И человек его возвышеннее сологубовского чародея, которому надо извне скликать святыню, бога, Аьявола... У него Ауша - алтарь

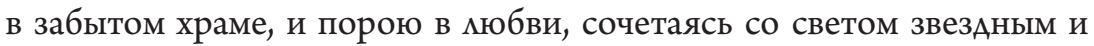


возАюбленной, делается созвучьем вечного псалма. И не его вина, что он только ткач, с грустью всю Аолгую жизнь свою ткущий собственный саван. Он все жАет еще чего-то высшего и не в силах опустить на мицо свое маску с узаконенно-иронической улыбкой безусловного пессимиста. Он из могикан того прошиого, когда уповами, умирая... И в общем его книга - раздумья мыслитекя по призванию, но Аполмон чувствовац, что мысль поэта искала ритма; только осенил ее както мимоходом. И некоторая серая монотонность финлянаских утесов стала неизменным фоном величавых песен... САержанный в чувстве и благородный в способах изАить мысль, поэт все же обделен стихийностью. И он это сознал уже... Чем ближе к концу разбираемого сборника подвигаешься, тем ярче бросаются в глаза Аостижения... гордого в своей тоске Ауха... » (БранАт 1911а: 13).

Автором рецензии был киевский поэт Никомай Генрихович Брандт. О его биографии известно очень мало: родился в семье Генриха Христофоровича Брандта - по-видимому, Аовольно обеспеченной, поскольку их аптека находилась в самом центре Киева, на ум. Большой Владимирской, 41 (Весь Киев 1911: 801, 976). Возможно, закончим 1-е реальное училище: в Национальной библиотеке Украины им. В.И. ВернаАского хранится экземпляр его Аебютной книги (БранАт 1907) с Аарственной наАписью преподавателю истории «Аорогому наставнику / Аеониду Павцовичу Аобровольскому / от автора. / Н.Г. БранАт $\gg^{3}$. Финансовое положение позволило ему выпустить в Киеве Ао первой мировой войны четыре поэтических сборника: «Тихие песни» (включавшие 9 переводов с английского, французского и немецкого), «Нет мира миру моему» (Брандт 1910; с посвящением «Милому моему Юлию Исаевичу Айхенвальду в знак глубокого уважения

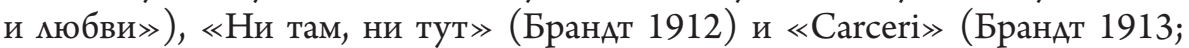
с эпиграфом из Р.М. Рильке и стихотворениями на немецком языке). ОАнако славы это ему не принесло - «Нет мира миру моему» раскритиковали Николай Гумилев в «Апомлоне» (Гумилев 1910: 37-38) и Валерий Брюсов в «Русской мысли» (Брюсов 1911: 231). В стихах Брандта ощутимо влияние Иннокентия Анненского, очевидное и в заглавии его первой книги; в третьем номере «Аукоморья» он посвятих Анненскому отАельную статью (Бранат 19116: 11-12; Тименчик 2017: 89-92). Брандт жих в Киеве как минимум Ао конца 1920-х гг., но после революции практически исчез с митературного горизонта. Он упомянут в репортаже о вечере киевских поэтов в июле 1922 г.: «Откровенные “старики” не только не смогли уловить существа “старого”, но в своей (говорят, оригинальной) мирике не Аали ничего своего. Вышло: ни своего, ни чужого. <...> “[И]сторический экзотизм” Брандта - плохой перепев плохих оригиналов. < .. > Переводные стихи ничуть не кучше оригинальных и, конечно, неизмеримо хуже оригиналов. Впрочем, некоторой свежестью повеяло от переводов Брандта»

3 НБУВ. В.14237/7538. 
(Бис 1922: 3). В 1930 г. он безуспешно пытался опубликовать в «Красной нови» стихотворение «Врасплох» о коннице Буденного, которое было отклонено редакцией и сохранимось в архиве журнала ${ }^{4}$. Аальнейшая судьба Брандта нам неизвестна; в базе репрессированных по Киеву и Киевской области Отраслевого государственного архива Службы безопасности Украины он не значится.

История «еженедельного имююстрированного митературно-художественного, бемметристического и популярно-научного журнала» « рье», гАе была помещена рецензия на «Земные ступени», исчерпывается тремя выпусками в октябре 1911 г. Журнал издавался в Киеве тиражом 2000 экземпляров; в реАакцию входили Иван Аксенов, Николай Брандт, Николай Животов, Бенедикт Аившиц, Сергей Никонов и ВАадимир Эмьснер (см. подробнее: Соболев 2013: 107-109). Обложку подготовил хуАожник Михаил Аенисов, иммюстрации к первому номеру - Александра Экстер. В конце 1920-х гг. Николай Ушаков писал: «Почти до самой революции Киев оставался во власти символистов. Еще в 1911 году вокруг эфемерного журнала "Аукоморье" группировались эпигоны этой школы Ник. Животов, Ник. Брандт, С. Никонов, Юрий Зубовский, В. Васикенко, В. Отраковский и Ар.» (Ушаков 1929: 120).

Произведения Балтрушайтиса не только публиковались, но и звучали со сцены. 27 апремя 1919 г. Киевское общество им. А.Н. Скрябина совместно со Всеукраинским музыкальным комитетом провело торжественное засеАание, посвященное памяти композитора (в это время в Киеве находились его вдова и Аети). Газетный анонс маконичен: «Сегодня в зале консерватории состоится утро, посвященное памяти А.Н. Скрябина. АоклаА, на тему: “Творчество А.Н. Скрябина, в плане современной культуры”, прочтет тов. Асман. После доклада состоятся выступления артистов и артисток с Аекламациями стихов современных поэтов, посвященных покойному гению» (Иекции 1919: 4). Больше подробностей содержится в заметке «Годовщина смерти Скрябина» Бюро печати при Совнаркоме Украины (сообщение № 14 «Хроники искусства и художественной промышленности» от 25 апремя 1919 г.): «артистки Тарасова, Зябкова и поэт Натан Венгров прочтут стихотворения Бальмонта, Брюсова, Вяч. Иванова, Бальтрушайтиса <так!> и Парнок, посвященные памяти А.Н. Скрябина»5. Спустя год сюжет был неожиданно закольцован: если в 1919 г. в Киеве Венгров принимал участие в чтении стихов Балтрушайтиса, то в 1920 г. в Москве Балтрушайтис рецензировал детскую книжку Венгрова «Зверушки» (Балтрушайтис 1920: 60-61; Саунькин 2016: 223) ${ }^{6}$.

4 РГААИ. Ф. 602. ОП. 1. ЕА. хр. 335. А. 1.

5 Центральный государственный архив высших органов власти и управления (ЦГАВО) Украины. Ф. 1738. Оп. 1. ЕА. хр. 49. А. 33.

6 Вопреки утверждению исследователя, републиковавшего текст, рецензию вряА ми можно назвать «неизвестной», поскольку ранее она была зафиксирована в 
Ао 1934 г. столицей советской Украины был Харьков, и там находились всеукраинские учреждения культуры и органы печати. Харьковская пресса информировала читателей не только о российских, но и о заграничных изАаниях с участием Балтрушайтиса. Так, например, в мае 1922 г. еженедельник «Художественная мысль» с опозАанием в несколько месяцев АважАы в 11 и 12 выпусках - сообщил о январском номере «Жар-Птицы», гАе было перепечатано стихотворение «Безмолвие» («Я в жизни верую в значенье... ») (Балтрушайтис 1922: 32): «Вышел № 6 журнала “Жар-Птица” ц. 8 фр. Париж. Содержание: Стихи Минского, Балтрушайтиса, А. Черного, А. Блока. Рассказы А.Н. Толстого, Ароздова, Пинегина, Сергеева. Статьи


налы 1922: 17).

Вероятно, в Харькове увидел свет и первый перевод поэзии Балтрушай-

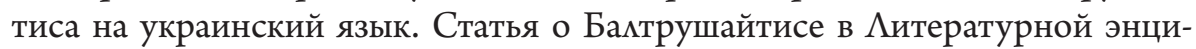
кмопедии, написанная Амитрием Благим, завершалась фразой: «Стихи Б. переведены на итальянский и болгарский яз» (БАагой 1930: 313). МежАу тем, в 1928 г., в 4-м номере журнала «Церква й життя» («Церковь и жизнь»), быи опубликован «Пасхальный звон» в украинском переводе А. Аепского:

\section{Пасхамьный звон}

Арогнул в мире звон пасхальный, Вспыхнул свет в Ауше опальной! Ярче, ярче искра Божья Среаь земного бездорожья ... АюАи, дети сна и тени, Становитесь на комени!

САаАок гулкий звон воскресный, Голос вечный, зов небесный ... В мире смерти, в мире боли, Молкнет ропот темной воли... ПобежАает искра Божья Тьму земного бездорожья, Аети сна и дети тени, Припадайте на комени! (Балтрушайтис 1911: 17)

\section{ВемикоАНИй АЗвін}

Азвін хитнувся Великодний

І в Ауші віАбивсь холоАній!

Спалахнука іскра Божа

В тьмі земного бездорожжя ...

ҺюАи сну і смутку Аіти,

На коліна припадіте!

Азвін гуАе, як гімн воскресний, Голос вічності небесний...

В царстві смерті і стражАання

Вже не чути нарікання...

Подолала іскра Божа

Тьму земного бездорожжя, -

Аіти сну і смутку Аіти,

На коміна припадіте!

(Балтрушайтіс 1928: 267; цит. по: Тен 1998: 83)

библиографическом указателе (Богомолов 1994: 127). Так же необоснованно преАположение П.С. Саунькина (Саунькин 2016: 224), что это «послеАняя, вышеАшая на русском языке при жизни автора» публикация Балтрушайтиса (ср. Аавринец 2013: 28). 
ПеревоА формально близок к оригиналу: в нем сохранены размер (четырехстопный хорей, имитирующий колокольный звон), женские клаузулы и смежная рифмовка. Если в подлиннике все рифмы адъективные или субстантивные, то в переводе - одна субстантивно-глагольная в рефрене. В 8 стихах из 14 совпадает количество слов. Вместе с тем, переводчик обеднил варьирующиеся строки первой и второй строф (4-12 и 6-14 соответственно), заменив их повторами, хотя вариации строк 3-11 и 5-13 воспроизведены. Алящееся и развивающееся действие изображено как свершившееся: «вже не чути» («уже не слышно») вместо «молкнет», «подолала» («преодолела») вместо «побеждает». ОАнако в целом, на наш взгляА, перевод передает и содержательное, и стилистическое, и версификационное мастерство Балтрушайтиса.

Републикуя китературные материалы из журнала «Церква й життя», Г.А. ЗАенко ${ }^{7}$ высказал убедительное предположение (ЗАенко 1998: 70-73), что поА Псевдонимом «А. Аепський» (возможно, восходящим к писатеАю и путешественнику XVII в. Павлу Алеппскому) скрывался поэт и переводчик Мыкола Васильевич Хомичевский (1897-1983). Протоиерей Хомичевский быи настоятелем храма св. Софии (1924-1926) и Петропавловской парафии (1924-1928) в Киеве; в августе 1929 г. арестован, осужден на 10 мет магерей, но Аосрочно освобожден в сентябре 1936 г. (Бухамо 1998: 84-95). В украинской митературе он известен поА Аругим псевАонимом, которым подписывал светские сочинения и переводы, - Борис Тэн. Хомичевский переводил на украинский язык Эсхила, Софокла, Аристофана, Шекспира, Шимлера, Мицкевича, Верлена, Пушкина, Толстого, мибретто опер и Ар. (Білокінь 1988: 488-505); он успел осуществить полный перевоА «ОАиссеи», а затем «Илиады» Гомера, а также выпустить маменький сборник собственных сонетов «Зоряні сади» («Звездные сады»; Тен 1970).

Журнал «Церква й життя» издавался в Харькове Всеукраинским православным церковным советом - высшим органом Украинской автокефальной православной церкви (УАПЦ). РеАактировац его митрополит Васыль Аипкивский, а затем архиепископ Иван Павловский. Журнал выходил тиражом 2500 экземпмяров в 1927-1928 гг. и быи прекращен из-за репрессий против УАПЦ. В четвертом номере содержалась пасхальная подборка: переводы «Пасхального звона» Балтрушайтиса и Noli me tangere, Maria! Брюсова и три стихотворения пасхамьной тематики самого А. Аепского - «Вемик-

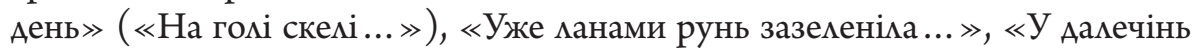
старий прославсь гостинець ...» (Тен 1998: 76-77, 82-83).

Произведения Балтрушайтиса, очевидно, знали и в украинской провинции. Михаил Горяйстов вспоминал о митературоведе и поэте Викторе Абрамовиче Гофмане (1899-1942): «К началу учебного года в 5-м классе Полтавской 1-й гимназии (1914г.) В. Гофман и я были уже близкими

7 Григорий Аемьянович ЗАенко (1934-2015) был одним из первых исследователей темы «Балтрушайтис и Украина» (ЗАенко 1980: 170-174). 
Арузьями. Нас сблизила Аюбовь к митературе. Витя Гофман хорошо знал поэзию, в особенности современную, интересовался теорией митературы. У него была большая библиотека, которую он и его отец (Аоктор - виАный специалист по болезням уха, горла и носа) регулярно пополняли новинками и которой пользовался и я. Сам Витя Гофман писал стихи и при кажАой встрече знакомия меня с ними. Особенно мюбил он символистов не было ни оАной встречи, во время которой он не читал бы произвеАений А. Блока, А. Белого, Ю. Бальтрушайтиса <так!>, В. Брюсова, К. Бальмонта, В. Иванова, А. Ремизова, Ф. Сологуба и Ар. $>^{8}$ Вместе с тем, в фундаментальной статье Гофмана «Язык символистов» (Гофман 1937: 54-105) Балтрушайтис не упомянут.

Итак, митературная известность Юргиса Балтрушайтиса в Украине предшествовала официальной Аипломатической. Его поэзия была доступна читателям в оригинале и переводе, в антологиях и периодике, критических откликах и журнальной хронике, в столицах и провинции, в печати и со сцены. Материалы местной печати и культурной жизни 1910-20-х гг. не только Аополняют персональную библиографию Балтрушайтиса, но и расширяют общее преАставление о рецепции поэзии русского символизма в украинской митературе.

\section{Литература}

Бамтрушайтис, Ю. (1911). Земные ступени: Элегии, песни, поэмы. Москва: Скорпион. 212 c.

Балтрушайтис, Ю. (1920). Натан Венгров. ХуАожественное смово: Временник Аитературного отдела НКП. Кн. І-ая. Москва: ИзА. Народного комиссариата по просвещению. С. 60-61.

Балтрушайтис, [Ю]. (1922). Безмомвие («Я в жизни верую в значенье...»). ЖарПтиица. Париж; Берлин. № 6. Январь. С. 32.

Балтрушайтіс, Ю. (1928). Великодний Азвін. Пер. А. Аепського. Церква й життля. Харків. № 4. С. 267.

Белов, Г.А., и Ар. (1959) / реА. кол. Аокументы внешней политики СССР. Т. 3.1 июмя 1920 г. - 18 марта 1921 г. Москва: ГосполитизАат. 723 с.

Бис. [Бачелис, И.?] (1922). Вечер группы киевских поэтов. Пролетарская правда. Киев. № 153.11 июмя. С. 3.

Бімокінь, С.І. (1988) / укм. Матеріали до бібліографії Бориса Тена. В: Жадань і задумів неспокій: 3 творчої спадщини Бориса Тена: Вірщі, переклади, статті, ^исти, спогади. Журавський, А.Ф., Аенець, К.В. / упоряА., підгот. пубц., прим. Київ: РаАянський письменник. С. $488-538$.

Благой, А. (1930). Балтрушайтис. В: Аитературная энциклопедия: В 11 т. Т. 1. Москва: ИзА-во Коммунистической академии. Стб. 311-313.

8 Горяйстов, М.Ф. Аитературный кружок В.А. Гофмана (1915-1923 г2.): Воспоминания. Центральный государственный архив-музей митературы и искусства (ЦГАМАИ) Украины. Ф. 260. Оп. 1. ЕА. хр. 13. А. 7. Горяйстов Михаим Федорович (1897-1968) - журналист, профсоюзный работник. Подробнее о полтавском Аитературном кружке см. (Поберезкина 2017: 78-86). 
Богомолов, Н.А. (1994). Материалы к библиографии русских митературно-художественных альманахов и сборников. 1900-1937. Т. 1. Москва: Мантерна; Вита. $623 \mathrm{c}$.

Бранат, Н.Г. (1907). Тихие песни: Стихотворения. Киев: Типография Р.К. Аубковского. $71 \mathrm{c}$.

Брандт, Н. (1910). Нет мира миру моему: Вторал книга стихов. 1908-1910. Киев: Типография акционерного общества «Петр Барский в Киеве». 96 с.

Брандт, Н. (1911а). Юргис Балтрушайтис. [3]емные ступени. Скорпион. Москва, 1911 г. Аукоморье. Киев. № 1. С. 13.

Брандт, Н. (19116). Об Анненском. Аукоморье. Киев. № 3. С. 11-12.

Брандт, Н.Г. (1912). Ни там, ни тут: Третья книга стихов. 1910-1912. Киев: Типолитография «Прогресс». $64 \mathrm{c}$.

Брандт, Н. (1913). Carсеri (Темницы): Четвертая книга стихов. Киев: Типография «Прогресс», 3.М. Сахнина. 96 с.

Брюсов, В. (1911). Новые сборники стихов. Русская мысль. № 2. Февраль. С. 227-234, 2-я паг.

Бухамо, Г. (1998). Аві сторінки його життєпису. В: Тен, Б. Скороминущих років буревій: Аітературна спадщина. Спогади про Бориса Тена. Аокументи. Шморгун, Є. I упоряд., реА. Рівне: Азалія. С. 84-95.

Весь Киев (1911). Весь Киев: Адресная и справочная книга на 1911 г. Киев: ИзА. С.М. Богуславского. 144+XIX с.+1983 стб.

Волны вечности (1914). Волны вечности в русской художественной литературе. Киев: Киевское религиозно-фияософское общество. 520+VIII с.

Гцухова, Е.В. (2010) / сост. Бамтрушайтис Юргис Казимирович (1873-1944). В: Русская митература кониа XIX - начала XX века: Библиграфический указатель. Т. I (А-М). ГАухова, Е.В. / отв. реА. Москва: ИМАИ РАН. С. 129-136.

Гофман, В. (1937). Язык символистов. В: Аитературное наследство. Т. 27-28. Москва: Журнально-газетное объединение. С. 54-105.

Гречишкин, С.С. (1989). Балтрушайтис Юргис Казимирович. В: Русские писатели. 1800-1917: биографический словарь. Т. 1. А-Г. Николаев, П.А. / гл. реА. Москва: Советская энцикмопедия. С. 146-148.

Гумилев, Н. (1910). Письма о русской поэзии. Апомлон. № 9. Июль-август. С. 35-38, 2-я паг.

Гумилев, Н. (1913). Антология современной поэзии. Аполюон. № 2. С. 71-72.

Аополнительный Аоговор (1922). Аополнительный договор к мирному договору между Украинской Сочиалистическ. Советской Республикой и Аитовской Аемократ. Республкой: Материал к пункту ... ........му повестки 3 сессии ВУЦИКА. Харьков: 1-я Гос. мито-типография. 15 с.

Аробинский, Я.С. (1911) / сост. Аитературно-художественный чтеи-декламатор: Сборник стихотворений, поэм, рассказов, монологов и пр. в трех частях. Киев: И.И. Самоненко. $698+$ XVIII $c$.

Жар-Птица (1922). Жар-Птица № 6. Художественная мыссль. Харьков. № 11. 30 апремя - 6 мая. С. 19.

Забігайло, К.С., Михайловський, М.К., Хміль, І.С. (1966) / упоряА. Українська РСР на міжнародній арені: Збірник документів (1917-1923 рр.). Київ: Наукова думка. 667 с.

3Аенко, Г. (1980). Ава приезда Балтрушайтиса. Аитва митературнал. № 3. С. 170-174.

Зленко, Г. (1998). Мамознаний Борис Тен. В: Тен, Б. Скороминущих років буревій: Аітературна спадщина. Спогади про Бориса Тена. Аокументи. Шморгун, Є. / упорян., реА. Рівне: Азалія. С. 70-73. 
Каратыгин, С.В. (1911) / сост. Новый чтеи-декламатор: Аитературно-художественный сборник. Стихотворения, рассказы, сцены и монологи для чтения с эстрады, на митературн. вечерах, драматических курсах и пр. в трех частях. Киев: Типография акционерного общества «Петр Барский в Киеве». 656+XV c.

Аавринец, П. (2013). Репутация Юргиса Балтрушайтиса в балтийской русской печати 1920-1930-х годов. Literatūra. T. 55, Nr. 2. С. 26-35.

Аекции (1919). Борьба. Киев. № 60. 27 апремя. С. 4.

Мир з Аитвою (1921). Вісти Всеукраїнського центрального виконавчого комітету Рад робітничих, селянських та червоноармійських депутатів. Харків. № 24.18 мютого. C. 1.

Павменко, В.В. (2004). Аоговір мирний між Українською СРР і Аитовською Аемократичною Республікою 1921. В: Енциклопедія історії України. Т. 2. Г-А. Смолій, В.А. / гол. редкол. Київ: Наукова Аумка. С. 428.

Петровский, М.С. (2008). Мастер и город: Киевские контексты Михаила Булгакова. ИзА. 2-е, испр. и Аоп. Санкт-Петербург: ИзА-во Ивана Иимбаха. 464 с.

Поберезкина, П. (2017). Полтавские читатели О. Мандельштама. В: Мандельштам читатель / Читатели Мандельитама: Филологический сборник. Аекманов О.А., Устинов, А.Б. / реА. Modern Russian Literature and Culture. Studies and Texts. New Series. Vol. 1 (47). Stanford: Aquilon Books. C. 75-87.

Рогожин, Н.П. (1958) / сост. Аитературно-художественные альманахи и сборники: Библиографический указатель. Т. 2. 1912-1917 годы. Москва: ИзА-во Всесоюзной книжной палаты. 528 с.

Русские журналы (1922). Художественная мысль. Харьков. № 12. 6-13 мая. С. 17.

Самоненко, Ф.М. (1912) / перераб. и Аоп. Антология современной поэзии. Чтецдекламатор. T. IV. ИзА. 2-е. Киев: Типография акционерного общества «Петр Барский в Киеве». 759 с.

Самоненко, Ф., Эмьснер, В. (1909) / реА. Антология современной поэзии: Америка, Англия, Франиия, Бельгия, Германия, Италия, Скандинавия, Польша, Россия. Чтецдекламатор. Т. 4. Киев: Типография «Петр Барский». 658+XII с.

Саунькин, П.С. (2016). О неизвестной публикации Ю. Балтрушайтиса. Научный диалог. № 12 (60). С. 222-227.

Соболев, А.А. (2013). Аетейскал библотека: очерки и материалы по истории русской митературы XX века. Кн. І. Биографические очерки. Москва: Трутень. 488 с.

Тен, Б. (1970). Зоряні сади: Сонети. Київ: РаАянський письменник. 103 с.

Тен, Б. (1998). Скороминущих років буревій: Аітературна спадщина. Спогади про Бориса Тена. Аокументи. Шморгун, Є. / упоряА., реА. Рівне: Азалія. 125 с.

Тименчик, Р. (2017). К истории кумьта Анненского. В: Тименчик, Р. Подземные классики: Иннокентий Анненский. Николай Гумилев. Москва: Мосты культуры; Иерусалим: Гешарим. С. 77-254.

[Ушаков, Н.] (1929). Н. У. Киев и его окрестности. В: Ветер Украины: Альманах ассоциации революиионных русских писателей «АРП». Кн. 1. Киев: Ассоциация революционных русских писателей «АРП». С. 120-133.

Чтец-декламатор (1913). Т. III, изА. III. Киев: Типография акционерного общества «Петр Барский, в Киеве». 624+XIV с.

Чтец-декламатор: Новая поэзия (1912а). Т. 3, изА. 2. Киев: И.И. Самоненко. 564+XII с.

Чтеи-декламатор: Художественный сборник стихотворений, монологов и рассказов. Аля чтения в дивертисментах, на драматических курсах, митературных вечерах и т. n. (19126). Т. II, изА. 6-е. Киев: Типография акционерного общества «Петр Барский в Киеве». 678+XXVI с. 
J. Baltrušaitis 20. gadsimta 10.-20. gadu Ukrainas presē

Jurgisis Baltrušaitis Ukrainas vēsturē ir pazīstams kā lietuviešu diplomāts, taču pirms tam viņš bija zināms kā dzejnieks. Rakstā aplūkota viņa literāās daiḷrades recepcija Ukrainas periodikā un arhīvu fondos. Raksta autore aktualizē atsevišķas publikācijas Kijevas antoloǵijās, Nikolaja Branta recenziju, kā arī analizē pirmo J. Baltrušaiša dzejas tulkojumu ukrainu valodā (Mikolas Homičevska tulkojums).

\section{J. Baltrušaitis in the press of Ukraine 1910-20-ies}

Jurgis Baltrušaitis entered the Ukrainian history as a Lithuanian diplomat but previously he was known as a Russian poet. This paper presents the evidence of the reception of his literary works from local periodicals and archives and focuses on several publications in the Kiev anthologies and the book review by Nikolai Brandt, as well as analyses the first Ukrainian translation of his poem by Mykola Khomychevsky. 
DOI: http://doi.org/10.22364/ruslat.glp.08

\section{Оксана Пашко}

\section{Студент-филолог в Советской Украине 1920-х гг. (на материале записных книжек Соломона Рейсера)}

В статье анализируются неопубликованные записные книжки Соломона Абрамовича Рейсера (1905-1989), которые хранятся в киевском архиве Института митературы им. Т. Шевченко НАН Украины (Киев). В работе показано, что такие эго-Аокументы могут стать важным источником Амя изучения митературной и культурной ситуации в Киеве 1920-х гг. Также на основе архивных документов идентифицируется кичность близкой знакомой С. Рейсера, Анны Николаевны Оберучевой (1891-1982), участницы одного из первых громких политических процессов в СССР - Киевского областного Центра Аействия (1923-1924), своячницы культуролога и историка Николая Павловича Анциферова.

Ключевые слова: Соломон Абрамович Рейсер, Николай Павлович Анциферов, Анна Николаевна Оберучева, Татьяна Николаевна Оберучева, Илья Эренбург, Андрей Белый, Аневник, эго-документ, 1920-е годы, Киевский областной Центр Аействия

1920-е годы - переломные годы в истории, время формирования нового советского человека, периоА политических, социальных и культурных экспериментов. Этот периоА Аовольно поАробно воспроизводится в разАичного рода эго-Аокументах, в частности в Аичных Аневниках молоАыХ АЮАей 1920-х годов. ОАнако Аневниковых записей мичного характера, описывающих жизнь молодого человека в Советской Украине 1920-х годов, мало. В этой статье речь пойдет о неопубликованных записных книжках Соломона Абрамовича Рейсера (1905-1989), в будущем известного текстолога и митературоведа, который в 1917-1926 гг. жим в Киеве. Эти Аокументы хранятся в архиве С.А. Рейсера в Институте митературы им. Тараса Шевченко НАН Украины (отАел рукописей) и Ао сих пор не привлекали внимание ученых. Граничные Ааты «киевского архива» С. Рейсера: начало 1920-х начало 1930-х годов. В статье исследуются записные книжки 1922-1926 гг. (ИА, ф. 243, А. 26, 34, 38, 39), когаа С. Рейсер бым студентом Высшего института народного образования им. Арагоманова (ВИНО), куда он поступим в 1921 году (ИА, ф. 243, А. 41, А. 1). Сформированные в несколько архивных дел записные книжки С. Рейсера - это около Аесятка блокнотов, общих тетрадей (на обложках которых характерные Аореволюционные виньетки), отдельные мисточки мелко исписанных записей. Некоторые из тетрадей имеют самодельную обложку, на которой фиксируются конечные 
Ааты записей и периодически указывается жанр записей: «Заметки, мысли, конспекты, выписки и пр.» (ИА, ф. 243, А. 34), «Записники. 1923-1926»

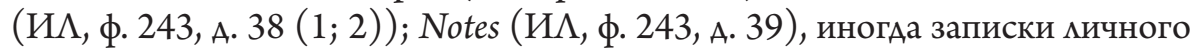
характера перемежаются конспектами прочитанной митературы: «ТетраАь

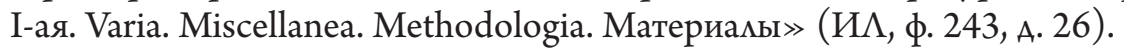

Стилистически переА нами разнородные заметки: описание событий, пересказ случайно подслушанных анекдотов, слухов, разговоров, записи песен - своего рода «литература факта» в Аухе 1920-х; также имеются конспекты прочитанных книг; пересказ мекций; иногАа приводятся рефлексии наА случившимся, есть мирические отступления; порой это обращение к себе с призывом изменить жизнь, своеобразное самовнушение; некоторые тетради имеют эпиграфы. В 1924 году Аневники становятся слержаннее, появАяются черты эзопового языка, некоторые отрывки пишутся по-английски или по-немецки.

Родился С. Рейсер в 1905 году в Пуще-Водице, поселке городского типа, месте дач киевмян, с августа 1917 года семья переезжает в Киев. С 1921 года он учится в Высшем институте народного образования Киева (так называемом ВИНО ${ }^{1}$, Ао советской реформы образования - Киевский университет $^{2}$ ). Записи были сАеланы С. Рейсером в возрасте от семнадцати мет Ао АваАцаТи ОАного Года.

Из мекционной книжки студента мы узнаем о прослушанных им Аисциплинах и успеваемости (в основном «уАовлетворительно» и «хорошо», только по истории Аревнерусской митературы, истории новой русской $и$ тературы и народной словесности - «отлично»). Тема кандидатской работы С.А. Рейсера формулировалась таким образом: «Из наблюдений наА русским стихом в связи с преподаванием поэтики в школе» (ИА, ф. 243, А. 41, ^. 4-6). В связи с непролетарским происхождением, С. Рейсер Аолжен был платить за свое обучение, поэтому первую половину Аня он работал. Служиц он в отАеле техотчетности Коммунального преАприятия государственного коммунального хозяйства, где познакомился с Анной Николаевной Оберучевой, помощником завеАующего поАотАела, ставшей оАной из важных героинь записок молодого студента.

Из записных книжек мы можем реконструировать образ автора - своеобразного молодого человека 1920-х гг., ироничного, иногАа циничного, в меру карьериста («ЗАоровый карьеризм в жизни необходим. Без него пропадешь ни за что» $(И \Lambda, ф .243$, А. $38(1), \Lambda .6))$, который и по воспитанию, и

1 Такой советский новояз, странного рода аббревиатуры, пародировались киевмянами: «Бывшее “ВИНО” называется теперь “КИНО”... от университета до КИНО “Аистанция огромного размера”» [перевод мой. - О. П.] (3.11.1924, Єфремов 1997: 158).

2 Реформа образования в Украине была направлена на сокращение в учебном процессе академической составмяющей и увеличение пеАагогической. 
по скиаду характера, и по случившимся с ним в этот период событиям воспринимает советскую вцасть как чужую.

Отметим, что в отличие от России, в Украине советское правительство окончательно утверАилось только в апреле 1920 года после многочисленных политических изменений, поэтому и воспринимацась часто как инородное тело. Молодой Рейсер солиАаризируется с Жорж Санд в скептическом отношении к Аемосу, цитируя ее высказывание о том, что во всеобщем избирательном праве «число господствует наА умом» (ИА, ф. 243, А. 38 (2),

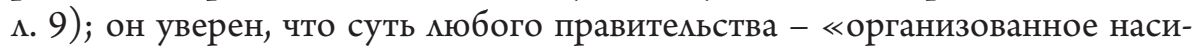

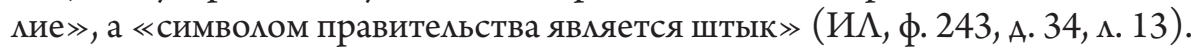
С. Рейсер констатирует у некоторых коммунистов болезнь «комчванство», иронизируя: «на каком сборе, то бишь < ...> съезде партии, принят Аогмат

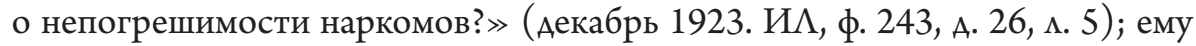
чужАы тексты-манифесты советской идеологии: «Аля меня всегАа были не понятны слова "Интернационала" "Никто не Ааст нам избавменья, ни Бог (понятно), ни царь (то же) и ни герой (?)”. Вот тут не понятно. Без геройства освобождения не будет» (Аекабрь 1923. ИА, ф. 243, А. 26, А. 13 об.).

На фоне популистских и агрессивных слоганов про борьбу, характерных Аля 1920-х годов, Рейсер считает борьбой шашки, шахматы, мыжи, теннис. Своими «боевыми Анями» он называет занятия и находит упоение в «боевой радости в области мичного усовершенствования» (ИА, ф. 243, А. 34,

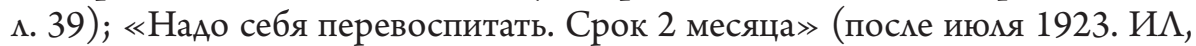

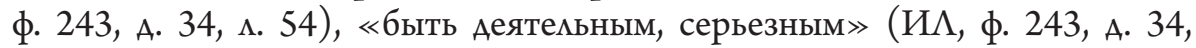
$\Lambda .55)$; говорит о важности «самоограничения», «не ругаться - слеАить за своим языком - это очень важно» (ИА, ф. 243, А. 39), «сделать себя заня-

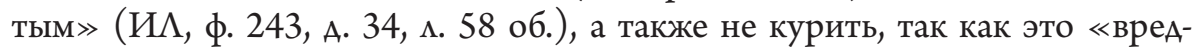
ная привычка», «вреАно отражающаяся на организме нервных субъектов (и я такой). Расслабцяет, отнимает много времени и денег» (9.08.1923. ИА, ф. 243, А. 38 (1), ^. 68). А. Рожков в книге «В кругу сверстников» описывает Аве «биографические стратегии» молодых мюдей 1920-х гг.: «мужики» (пролетарское происхожАение, общественная активность, намеренная грубость) и «жоржики» (непролетарское происхождение, намеренная воспитанность, сАержанность, аккуратность в одежАе) (Рожков 2016). С. Рейсер представляет в своих записных книжках желаемую Аля него вторую стратегию повеАения.

В плане милитаризации, службы в армии, С. Рейсер - не советский чемовек, на него угнетающе Аействует атмосфера военных учрежАений, казармы. Он мюбыми способами хочет избавиться от призыва в армию. Не разделяет он и митературные вкусы советской власти, категорически отрицая «пролетарскую поэзию», не понимая, по каким критериям ее вообще можно вылелить. Многочисленны свидетельства С. Рейсера о новом советском быте. Отличительным запахом нового быта является «канализационная вонь» («Что же Аелать, если оказывается, что мавровый венок Коммунальных ПреАприятий пахнет запахом сточных вод ОтАела Коммунальной 


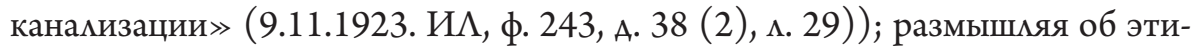
мологии ругательств, он отмечает распространение «порнографических картинок» $(6.10 .1923 . И \Lambda$, ф. 243, А. 38 (2), ^. 26), говорит о взятках и безработице. Эту корреляцию мотивов нечистот и советской власти встречаем и в Аневнике известного украинского митературовеАа и киевмянина Сергея Ефремова в 1924 году: он пересказывает слух о том, что в мавзолее прорвало канализационную трубу и залило помещение, причем это событие «воспевалось» в стихотворении и частушке, которые Ефремов цитирует: «Николай почим в Бозе, а наш Аенин - в навозе» (Єфремов 1997).

Упоминая о празАновании Октябрьской революции в 1923 году, Рейсер отмечает, что «особого подъема не было», он объясняет это тем, что «киассового сознания у народа, у массы нет, а национацьное есть в сильной степени» (ИА, ф. 243, А. 38 (2), ^. 30). Стихия анекАотов, слухи, которыми, «киевляне вознагражАают себя» (по М. Букгакову), своеобразное народное осмысление идей революции, которое можно было бы назвать «тихим сопротивлением» 1920-х годах, - тема отАельного исследования. Некоторые из анекдотов фиксируются Рейсером после посещений базара, записывается «подслушанное» в магазине, на умице, - эти моменты демают записки ценным источником по истории 1920-х. 24 января 1924 года, когда заговорили о смерти Аенина, С. Рейсер делает запись: «О Аенине уже бреАки. 1) Кто бым Аенин слышу я на Хрещатике? ЗАорово! 2) ГАе похоронят - не в императорском склепе $\Lambda и$ ? Еще кучше 3) Кто отпевать бу-

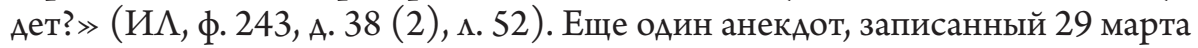
1924 г., обыгрывает советские мозунги, однако оценивается Рейсером как вульгарный: «Рассказывают, что утробные младенцы устроили митинг. Выставили по обсужАении ряА требований: 1) мало места - расширить жикую площадь, 2) темно - электрификацию, 3) не Аают свободы слова и 4) половых сношений. В общем, грубо» (ИА, ф. 243, А. 39, м. 26). Приведем еще несколько очень точных зарисовок киевского советского быта. 7 августа 1924 года С. Рейсер записывает: «Запрещены к продаже в кн<ижных> магазинах фимософы-идеалисты. Sic!» (ИА, ф. 243, А. 26, м. 22 об.). Аействительно, с приходом в Украину советская власть производила тотальную чистку книжных магазинов и библиотек с последующим запретом продажи определенных категорий митературы. Фиксируются в записках мелочи киевского церковного быта: «Аовкие, черт возьми, ребята. На витрине объявлений малой церкви Соф<ийского> Собора. 1) Храм - место Ауховного общения с Богом. 2) Хор - украшение храма. 3) Жертвуйте на хор и на

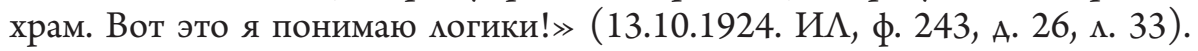

ИАеи 1920-х годов о важности гигиены близки С. Рейсеру и реконструируются из описания его распорядка Аня: «ФизотАел вполне хорошо. Сплю 8 часов. Утром и вечером гимнастика. Часто моюсь. Волос кручу мало. ЕАа нормально. Чувствую себя хорошо, холода не ощущаю... Совершенно нет. Характер. Трудно. Очень трудно изгнать эротомечтательность... Вообще я 


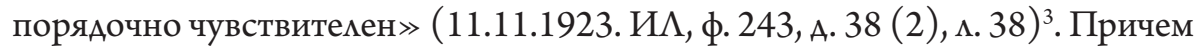
занятия спортом, гимнастикой студент скорее воспринимах не в контексте поАготовки своего тела к труАу и военной службе, как советские иАеологи 4 , а как что-то подобное чистому искусству викторианской эпохи, траАиции, восходящей к привычкам АенАи: «Спорт или физкультура. Принц Уэмьский $<\ldots>$ может Аелать, конечно, что ему угодно, но <...> молодежь, идущая в “спортклубы” в кавычках, Аолжна отАавать себе отчет, зачем идет она туда. ИАет ми она туда заниматься спортом. НЕТ! Этого ей не нужно. Чистый спорт=чистое искусство - нам сейчас не нужен» (5.05.1924. И А, ф. 243, А. 39, м. 36). Примечательно, что размышляя о роли спорта в жизни молоАого человека, он упоминает имя принца Уэльского, будущего ЭАуарда VII, который воспринимался как икона стимя 1920-х гг., преАставцяя собой типаж аристократа-спортсмена (Вайнштейн 2005: 561).

ОАнако не столько увлечение физкультурой Аелает молодого Рейсера похожим на молодого человека 1920-х годов ${ }^{5}$, сколько служба: как и большинство студентов того времени, он служил в конторе. ОАнако со службой, а особенно с «общественной работой», в записках связаны мотивы «омещанивания», «обмельчания», некоторой пошлости. Женщина, которая служит и занимается общественной работой, Аля молодого человека становится «общественницей» и «старой Аевой». Причем, если в мексиконе 1920-х годов «мещанство» связывацось со старомодностью, пошиостью, то Аля Рейсера именно слова «старомодный», «уютный» наполнены поможительными смыслами, тогда как «мещанство» - это знаки нового советского быта.

Несмотря на то, что Рейсер воспитывался в еврейской семье, у него в записках не отражается еврейский быт или кумьтура - ни на уровне речевом, ни тематическом, молодой человек ассоциирует себя исключительно с русской культурой. Исключения составляют размышления об антисемитизме, о Первой мировой войне и об обострившемся к середине 1920-х годов в СССР национальном вопросе. Он фиксирует анекдоты, например: нельзя говорить «поА-жидать трамвай», наАо говорить «под-евреивать

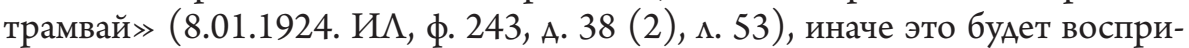
ниматься как антисемитизм. Анализируя причины антисемитизма, С. Рейсер вспоминает работу С. Аурье «Антисемитизм в Аревнем мире» (1922), с которой знакомился по рецензии в журнале «Анналы» (1923); по его

3 По сравнению с описанными А. Рожковым случаями нищеты, голода, неустроенности студентов 1920-х гг. (Рожков 2016), С. Рейсера вполне можно отнести к группе благополучных студентов.

4 Хоффманн пишет о советских концепциях физического труАа, важного «А^я поступательного Авижения на пути социального строительства» (Хоффманн 2018: $155)$, о том, что в СССР «часто не разделяли идеологическое зАоровье и физическое» (Хоффманн 2018: 169).

5 ОАнако А. Рожков считает, что «спорт... не стал в 1920-е годы массовым явлением в среде студентов» (Рожков 2016: 344). 
мнению, причина антисемитизма в том, что евреи «быстро осваиваются в новой атмосфере (их приспособляемость феноменальна), начинают себя чувствовать равноправными гражданами всюду (я русский)» (30.08.1923.

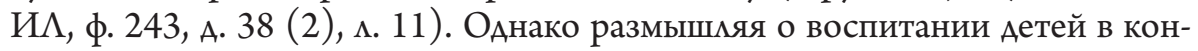
сервативной русской семье, он признает свою «чужАость» этим настроениям: «От этой вежливости православно-русской семьи, читающей “Новое время”, пьющей чай из самовара и идущей на войну, мне подчас Аелается как-то не по себе» (13(?).11.1923. ИА, ф. 243, А. 38 (2), ^. 33).

Отметим, что периоА киевской истории, зафиксированный Рейсером, явмяется периодом украинизации, когда преподавание в учебных заведения переводилось на украинский язык, а также все служащие Аолжны были саавать обязательный экзамен на знание языка. Этот же периоА - 1920-е годы - явцяется расцветом украинской кумьтуры и митературы, - то, что впоследствии получит название «расстрелянное возрожАение». Хотя С. Рейсер успешно освоиц украинский язык и митературу, он не мыслил себя как исследователь украинской митературы, в его студенческих работах находим только отдельные упоминания о творчестве Михайля Семенко и Павла Тычины, также в архиве имеется работа, посвященная сравнительному анализу творчества М. Семенко и И. Северянина. В мичных заметках появляются такие записи: «Теперь в связи с преобразованием ВИНО в ИНО, в связи с его пеАагогизацией и украинизацией “оставание” мое там просто абсурдность, и главное - потеря времени» (23.05.1924. ИА, ф. 243, А. 38 (1), м. 25). Характерная Аетаць: он вспоминает, как зайцем проникнул на знаменитую постановку Молодого театра известного украинского режиссера $\Lambda$ еся Курбаса, однако ни слова не пишет о самом Курбасе, упоминая только название пьесы - «Газ» Т. Кайзера; поражен он был скорее не режиссурой, а «моАностью и огромностью Аекоративного устройства»

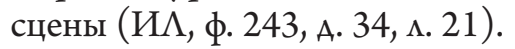

Характерно, что Рейсер принципиально не замечает «революционной» топонимики Киева, называя Пролетарский саА Царским. Вероятно, у него нет своего Киева, есть свой Петербург - в основном митературный, и когАа Киев совпадает с Петербургом - Петроградом - Аенинградом, он становится своим. Киевлянин Соломон Рейсер чувствует себя провинциалом. Собираясь в Москву, он записывает в Аневнике: «Только бы не быть в стомице Хлестаковым, или “гоголевским кузнецом”, попавшим в Петербург. Не Аелать УАивленные глаза, а “балетмейстеровать” $(19.10 .1923$. ИА, ф. 243, А. 38 (2), ^. 19 об.) (как можно догадаться, речь илет о гоголевском Вакуле).

В записках прочитывается еще оАин сюжет - проблема выбора будущей профессии: изучение митературы или поступление в Политехнический институт («теперешнее увлечение техникой очень симптоматично. Пришибленные революцией интемлигентики снова хотят кушать» (ИА, ф. 243,

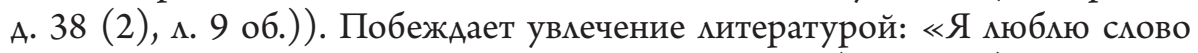
как таковое за то, что оно слово и больше не за что» $(1.11 .1923)$, «... грусть хватает мне сердце. Служи... учись в Политехникуме... брось филологию 


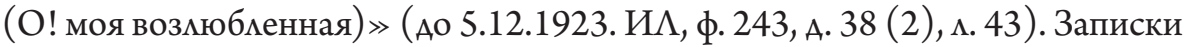
С. Рейсера - это записки инАивидуамиста, который не приемлет ничего колмективного; его путь к митературоведению - это не путь поэта или критика к научному изучению митературы, это путь ученого, преподавателя, который мечтает изучать митературу, сохранять свою индивидуальность и оставаться не включенным в современные события. «Но что сказать мне про

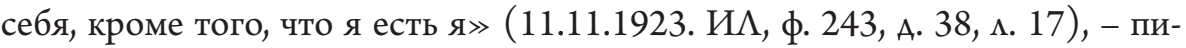
шет Рейсер, «Надо писать Я с большой буквы, как англичане» (ИА, ф. 243, А. 38 (2), ^. 11). Эта инАивидуацьность проявцяется в том, что он не хочет принимать участие в организации кружка «эсперанто» искмючительно «потому, что идее эсперанто не сочувствую, не вижу и не верю в его эфемерную сущность $\gg(И \Lambda, ф .243$, А. 38 (2), А. 20), хотя такое занятие и могло бы помочь ему в продвижении по служебной местнице. Соломон Рейсер начала 1920-х годов верит в способность мичности, а не комлектива преоАолеть все препятствия: «Гении не погибают. Тацанты тоже» (ИА, ф. 243, А. 38 (2), .47$)$, - уверен он.

В заметках прочитывается сюжет, который можно было бы назвать роман-воспитание, роман-карьера, Аовольно традиционная форма, характерная Аля романа XIX столетия. ОАна из центральных тем - карьера необходимость остаться на кафедре («я Аолжен все время иметь переА своими глазами выжженные в моем мозгу еАинственные Аля меня возмож-


Постоянно встречаем на страницах и обращение к себе - о необходимости учиться, самосовершенствоваться. Возможно, тут уже проявмяются те особенности Аневника советского человека, которые Аж. Хелбек называет «воспитание Ауха», «борьбой за усовершенствование» (Hellbech 2009: 68-74), подробно описанные им на примере Аневников стахинской эпохи.

Аругая центрахьная тема записок Рейсера - поиск мюбимой женщины и размышиения о том, кто такие женщины, и каковы советские «барышни». Многие страницы записок посвящены мичности незаурядной женщине, в которую Рейсер бым влюблен или думац, что был влюбленным, - Анне Николаевне Оберучевой. Она была арестована в декабре 1923 года и приговорена в 1924 году к пяти годам мишения свободы условно из-за обвинения в участии в Киевском областном «Центре Аействия» (это был один из первых громких процессов против украинской и русской интемлигенции (1924), который проходик в Киеве). Украинский историк Наталья Васименко-Полонская, жена одного из главных обвиняемых - профессора права Николая Василенко, очень ярко описала выступление на суде Анны Оберучевой: «Анна Оберучева заявила, что стоит за демократию, за свободу слова и печати, что она против Аиктатуры и за полное равноправие. Она идеалистка и не может принять марксизма. Это говорила молодая девушка, курсистка, говорила четко и ясно. Она была больна и единственная из всех Аавала показания сидя, тихим спокойным голосом. Тысячеголовая толпа 
замерла и жадно мовила каждое ее слово, которые произвели большое впечатмение» (Полонська-Васименко 2011: 344) ${ }^{6}$.

Кем же была Анна Оберучева? Речь илет о свояченице Николая Анциферова, сестре его жены - Татьяны Оберучевой. Анна после смерти своей сестры и ареста Анциферова в 1929 году заменила его детям мать, а после второй мировой войны эмигрировала в США․ Аействительно, осужАенная в 1924 году, в 1929 году она уже могла выехать из Киева в $\Lambda$ енинграА. В протоколе Аопроса А. Н. Оберучевой от 25.10.23 привоАится анкета, гАе имеются слеАующие сведения: «Год рождения: 1891 г. ${ }^{8}$ из иворян г. Киева; Где учился: в Киевской женской гимназиия и Петербургском женском политехникуме ${ }^{10}$ и КИНХе ${ }^{11}$; Во времл войны: сестра милосерАия; Кто родители: отец б<ывший> полковник, умер и мать Екатерина

6 Перевод с украинского мой. - О. П.

7 В протоколе Аопроса Анны Оберучевой по Аелу Киевского областного Центра Аействия говорится, что ее отец - бывший полковник, а мать Екатерина Михайловна. Такое же имя матери семьи Оберучевых называет и Н. Анциферов. Это косвенное подтверждение того, что Анна Оберучева из записок С. Рейсера и Н. Анциферова - одно и то же кицо. Еще одно подтвержАение - аАрес проживания семьи: с 1909-1915 гг. в справочниках «Весь Киев» встречаем запись о том, что Оберучева Ек. Мих. проживает по М<алой>.-Вцадимирской, 37 (с 1913 г. - Столыпинская) именно этот аАрес называет Н. Анциферов; однако в справочнике 1916 г. указано, что Ек. Мих. Оберучева проживает уже по адресу Фундуклеевская, 52 (Календарь 1916: 182) - а вот этот аАрес фигурирует в следственном деле как место проживания обвиняемой.

8 В оАном из протоколов Аопроса ошибочно указано: гоА рожАения 1881 г. (ГА СБУ, А. 55435, т. 18, ^. 2), в Аругом протоколе говорится, что ей 32 года (ГА СБУ, А. 55435 , т. 18, ^. 13). Скорее всего, родилась Анна Оберучева в 1891 году.

9 Записки С. Рейсера позвомяют установить, что речь идет о Государственной гимназии Святой Ольги (Ольгинской гимназии) (ИА, ф. 243, А. 34, м. 33). В 1892-1914 гг. гимназия помещалась во фмигеле Первой киевской мужской гимназии. Про эту же гимназию пишет Н. Анциферов, вспоминая о киевской молодости: «Таня заканчивала министерскую гимназию, которая помещалась рядом с нашей 1-й. Я помню, как мы взбирались на стену нашего саАа и наблюАали гумяющих по своему саду гимназисток» (Анциферов 1992: 124).

10 В Аругом протоколе Аопроса уточняются биографические Аанные: «Я дочь полковника, училась в Петербурге на Высших женских политехнич<еских> курсах, которые окончить не успела, так как началась война 1914 года, и я добровольно поступила на курсы сестер милосердия, по окончании которых я поступила в армию и была на фронте до октября 1917 г. Вернувшись затем в Киев, я занималась уроками, некоторое время служила в Украинском Красном кресте, а в 1920 г. поступила в Управление Киевскими Коммунальными предприятиями, сначала на должность телефонистки и чертежника, гАе служу и сейчас, занимая с 1921 г. Аолжность помощника заведующего отделом технической отчетности, отАел этот ведает статистической отчетностью работы коммунальных преАприятий» (ГА СБУ, А. 55435, т. 18, м. 14).

11 Киевский институт народного хозяйства. 
Михайловна; Место службы в настоящее время: пом<ощник> зав<едующего> подотаела техотчетности Ком. ПреАпр. ГХ. Х.; Постоянное место жительства: г. Киев» (ГА СБУ, А. 55435, т. 18, м. 2); Адрес проживания: Фунаукиеевская, 52, кв. 17 (сегодня Уи. БогАана Хмельницкого). Из протокола допроса также следует, что Анна Оберучева была знакома с Натамьей Жекулиной (Евреиновой), женой поэта и журналиста Бориса Евреинова (1888-1933): « ... осенью 1921 года мне принес... Иван Сергеевич Павлюк записку на папиросной бумаге от Наталии Жекулиной, находящейся в Праге, с просьбой служить передаточным пунктом организации, ставящей своей целью сообщение за границу информации о положении Сов<етской> России. Зная Н. Жекулину и мюбя ее, я на это согласилась > (ГА СБУ, А. 55434, т. 18, ^. 2 об.). Оберучева раз десять передавала запе-

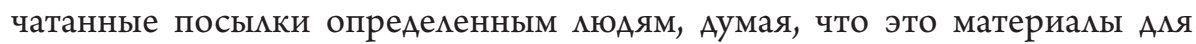
подготовки журнала. В своих показаниях в первом протоколе Аопроса она очень резко высказывается против советской власти: «А. Оберучева заявляет, что “советская вцасть Аолжна эволюционироваться..." Мое убеждение, что Коммунистическая партия сама придет к заключению о необходимости восстановления демократии. Вопр. Считаете ми Вы конспиративную Аеятельность актом враждебным соввласти? Отв. Аа, считаю ее актом враждебным. Вопр. Следовательно, вы являетесь врагом Советской вмасти? Отв. Аа» (ГА СБУ, А. 55434, т. 18, м. 2 об.). В тюрьме Анна Оберучева заболела, ее пытались забрать на поруки сотрудники учрежАения, в котором она работала (ГА СБУ, А. 55434, т. 18, ^. 15), оАнако им не позволили. ОАна из заключенных, участница процесса, Варвара Виноградова, в прошении следователю писала о состоянии зАоровья Оберучевой: Ава месяца пребывания в тюрьме отразились на ней «чрезвычайно тяжело», у нее порок серАца, слабые легкие и сильнейшее малокровие, «с ней почти ежеАневно бывают припаАки, сопровожАающиеся полной потерей сознания (явление анемии мозга) <...> появился крайне нехороший кашемь» (ГА СБУ, А. 55434, т. 18, м. 7-7 об.). Эти припаАки повторялись также во время суаа.

В записках «Из Аум о былом» Н. Анциферов создает очень выразительный портрет молодой Анны периода киевской жизни в Аоме «номер 37 : «молчаливая, замкнутая, со сАвинутыми бровями, она жила какой-то своей, неАоступной нам жизнью. Мы только замечали, как порой вспыхивали ее узкие глаза и что-то сильное, неукротимое просыпалось в ней. Она жила одной жизнью с нами, но как она ее преломляла в себе, никто из нас не знац. Мы называли ее “последовательницей Метерлинка”, ибо он учим молчанию» (Анциферов 1992: 123). Рейсер также оставим нам милые портретные зарисовки Анны Оберучевой, например, описав ее гардероб: «Анна Николаевна сегодня прелестна. Она пришла уже не в своем матроско-гомланаском костюме, а в черной юбке с белой старомодной блузкой. Блузка, вероятно, ее матери. Желтые чулки и такие же туфми дополнили ан-

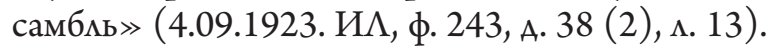


За месяц до ареста А. Оберучевой С. Рейсер посме отпуска был уволен со службы по сокращению штата (28 ноября 1923), спустя несколько месяцев он оказывается заинтересованным свидетелем политического процесса «Центра действия». С момента ареста А. Оберучевой его записные книжки кратко, но часто пестреют упоминаниями об арестованной. Ситуацию с советскими тюрьмами Рейсер преАставцял идеалистически, он описывает задумчивую женщину, которая одиноко стоит в камере и о чем-то Аумает. «My dear Anna. Love I you or not? Where know it? I don't know», спрашивает себя момодой человек после того, как побывал на суде, угадывается в этом сюжете что-то стендалевское, но наоборот, жертвой выступает женщина. Английский зАесь Аля того, чтобы потренироваться в языке, что свидетельствует скорее о наивности автора переА мицом трагических событий.

Размышияя наА собственной мюбовной историей, Соломон Рейсер много пишет о женщинах вообще. Он их оценивает очень консервативно, резко негативно относится к женской эмансипации, что находится в оппозиции к тенденциям женского Авижения 1920-х гг.: «Женщина, ставшая умной, теряет всякую женственность и приобретает мужественность» (после 19.10.1923. ИА, ф. 243, А. 38 (1), ^. 55). А.Н. Оберучеву он называет «интересной женщиной», по мнению Рейсера, женщине по природе свойственны «хитрость, скрытность, садистские наклонности» (ИА, ф. 243, А. 38 (1), м. 31-33). «Зачем женщины хотят быть мужественными. Разве им мало - быть женственными?» (ИА, ф. 243, А. 38 (1), А. 55), «рожАайте Аетей, варите пищу, шейте, читайте, если это и звучит старомодно» (ИА, ф. 243, А. 38 (1), м. 55). Он констатирует, что с революцией изменяется тип женщины, исчезают барышни. Но самые резкие высказывания встречаются у Рейсера по отношению к женщинам-«общественницам», которых он считает воплощением пошлости. Аюбопытно, что в киевской студенческой среде, в которой вращался Рейсер, был популярен 3. ФрейА: «ФрейА! О ты, ЗигмунА ФрейА, буАь милостив - истолкуй мой сон!» (7.06.1923. ИА, ф. 243, А. 38 (1), А. 34 об.) - молится советский студент, к тому же, он хочет подвергнуть психоанализу психологию современных советских Аевушек и ... шахматы.

Соломон Рейсер как человек, интересующийся митературой, периодически ходил на митературные вечера («Буду на Эренбурге. Видел Мандель-

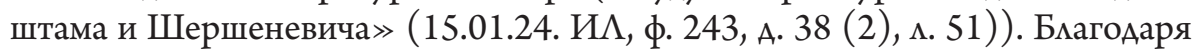
его увлеченности живым словом, имеем несколько уникальных отзывов о вечере Ильи Эренбурга и мекции Андрея Белого - обе состоялись в феврале 1924 г. В ранней юности Рейсер пережил большую увлеченность «Хулио Хуренито» Ильи Эренбурга, что потом не помешало ему считать этого писателя графоманом, наряду с Алексеем Толстым, Борисом Пильняком: «Если бы читатель читал, а не почитывал, не могли 6 существовать А.Н. Толстой, Пильняки и Эренбурги» (ИА, ф. 243, А. 38 (1), ^. 25). Эренбург, полагает Рейсер, А^я читатемей, «ААя которых чтение - это роА 
тюфячка, который они под себя подкмадывают, чтобы мягче бымо (сиречь не скучно), аналогично Пильняк. Мне это Ао крайности противно» (1924. ИА, ф. 243, А. 26, м. 19 об.).

Итак, 18 феврамя 1924 года Соломон Рейсер был на мекции И. Эренбурга; вот как он описывает свои впечатмения: «Эренбург типичный сопливый интемлигент, и сам буржуа ничуть не выше тех, на роль сатирика которых он претендует. Его митературность губит его... Речь его - рян мелких, а не метких, пошлых анекдотов, нагроможденных Аруг на Аруга. Если бы его докмаА сильно сократить, мог бы выйти толк» (ИА, ф. 243, А. 38 (2), м. 54). Из анонсов в киевских газетах можно преАположить, что речь скорее всего идет о мекции Эрнебурга «Пьяный оператор», посвященной современной Европе ([б.а.] 1924b: 4; [б.а.]. 1924c: 3).

Совершенно противоположно оценивает С. Рейсер мекции Анарея Белого (запись от 25 феврамя 1924 г.): «Бемый! Огромная величина. Гений! Он сумасшедший. Несомненно, или гениальный из гениальных актер. Он на меня произвел огромное впечатление. Как смел T. ${ }^{12}$ написать о нем поАобное. Он не смел написать так во всяком случае» (ИА, ф. 243, А. 38 (2), ^. 55). И чуть позже, 29 феврамя, он пишет: «Быть внутренне тактичным, воспитать в себе это, как говорит Белый (он на меня симьное, очень сильное впечатление произвел)» (ИА, ф. 243, А. 38 (2), ^. 55 об.). Киевская газета «Більшовик» анонсировала мекцию Андрея Белого «ОАна из обителей царства теней (о современной Германии)», которая состоялась 25 февраля в Пролетарском доме искусств ([б.а.] 1924а: 6). В записках молодого Рейсера мы имеем оАно из реАких свидетельств слушателей Эренбурга и АнАрея Белого в Киеве.

По-видимому, политический процесс «Центр Аействия», участницей которого стала Анна Оберучева, очень повлиял на самого Соломона Рейсера. Он замыкается, 5 января 1924 года пишет: «Стать еще более скрытным!» (ИА, ф. 243, А. 38 (2), м. 51). Изучая английский язык, С. Рейсер Аелает попытку вести Аневник на английском, возможно, чтобы зашифровать сообщение. ИногАа он пишет неопределенные местоимения: «те», «эти», - и зАесь уже очень сложно догаАаться о смысле сообщения. Эта осторожность молодого человека была обусловлена многими причинами. Следствие по Аелу «Центра Аействия» совпало со смертью Аенина, что также усугубимо напряженную обстановку в Киеве. Отметим, что уже через полгода (в октябре 1924 г.) после приговора обвиняемым (апрель 1924 г.) в Киеве начались «страшные аресты. Арестовано, говорят, около 700 человек» (28.09.1924. Єфремов 1997: 147). Также усилились меры по «чистке» среди студентов: «ВсюАу идет новая "чистка" - студентов, учитемей, скужащих. "Избиение ммаденцев тысячи"» (8.10.1924. Єфремов 1997: 150).

12 Скорее всего, имеется в виду высказывание $\Lambda$. Троцкого об Анарее Белом: «покойник, ни в каком духе он не воскреснет». 
К 1926 году на стилистическом уровне в записных книжках начинают прочитываться идеологические словечки современности: «статья по существу глубоко реакционна» (ИА, ф. 243, А. 39, ^. 16); «констатирую победу на фронте физическом» (ИА, ф. 243, А. 39, м. 37) - о роли самовоспитания; «типичная интемлигентская психология» (28 марта 1924, 243, 39: 24 об.). Появляются мысли о компромиссе с укрепмяющейся системой: «Что Вам комлективный Аоговор с ЦК КП заключить, что ми?» (конец 1923, после ареста А. Оберучевой; ИА, ф. 243, А. 38 (2), А. 40 об.), «В связи с полит <ической> проблемой надо что-то изменить в своем поведении» (ИА, ф. 243, А. 38 (2), 4). Судьба Анны Оберучевой и гибель самого близкого Аруга (он утонул) Аля Рейсера стали перемомными: он то впадает в Аепрессию, то восклицает: «Жить, жить, как хорошо жить» (15.04.1924;

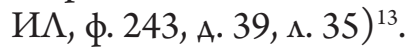

Подытоживая, можно сказать, что неопубликованные разрозненные черновые кичные записки Соломона Абрамовича Рейсера представмяют значительный интерес Аля изучения митературной ситуации в Киеве 1920-х годов - в статье преАпринята попытка обозначить наиболее весомые темы заметок. ПереА нами важный человеческий документ, в котором описывается внутренняя жизнь и взросление молодого мюбителя митературы и науки, волею судеб живущего в советском, чужом Амя него времени, и оказавшегосяся свидетелем важным исторических событий страны.

\section{Архивы}

ИА - Институт Аитературы им. Тараса Шевченко (Украина, Киев).

ГА СБУ - ГосуАарственный архив САужбы безопасности Украины (Украина, Киев).

\section{Литература}

Анциферов, Н.П. (1992). Из дум о бымом: Воспоминания / вступ. ст., сост., прим. и аннот. А.И. Аобкина. Москва: Феникс. 512 с.

Вайнштейн, О.Б. (2005). Аенди: мода, митература, стиль жизни. Москва: НАО. 640 с. Єфремов, С.О. (1997). Щоденники (1923-1929). Киев. 848 с.

Камендарь (1916). Справочная и адресная книга г. Киева. 1916 г. 836 с.

Оберучева, Анна Николаевна (1923-1924). ГА СБУ. № 55435, т. 18. 23 ^.

Полонська-Василенко, Н. (2011). Спогади / упоряА. В. Шевчук. Киев: ВиА. Аім «КиєвоМогилянська академія». $542 \mathrm{c.}$

[б. а.] (1924а). Аекція Білого. 25/II в Пролетарському будинку мистецтв мекція, тема: «ОАна из обителей царства теней». Більшовик. 21 февраля. № 43. С. 6.

[б. а.] (1924b). Аекция Эренбурга (18 февраля). Пролетарскал правда. 16.02. № 39. C. 4 .

[6. а.] (1924c). «Пьяный оператор» (о мекции Эренбурга). Пролетарская правда. 20.02. № 42. C. 3.

13 С. Рейсер перечитывал эти записи 29 Аекабря 1973 года, о чем он записац на помях (ИА, ф. 243, А. 34, ^. 25 об.). 
Рейсер, С.А. (1924, 1926, 1927). Записники С. Рейсера. 1924, 1926, 1927. Notes. ИА. Ф. 243. A. 39. 37 А.

Рейсер, С.А. (1922). Заметки, мысли, конспекты, выписки и пр. ИА. Ф. 243. А. 34.36 м. Рейсер, С.А. (1923, 1926). Записники. 1923, 1926. Miscellanea. ИА. Ф. 243. А. 38. № 1,

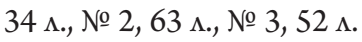

Рейсер, С.А. (1923-1924). Поэтика. Наука о композиции. Отдельные заметки мичного содержания. Тетрадь из конспектов и отдельных заметок. ИА. Ф. 243. А. 26. 111 А.

Рейсер, С.А. (1921). Аекционнал книжка студента. ИА. Ф. 243. А. 41.7 ^.

Рожков, А.Ю. (2016). В кругу сверстников: Жизненный мир молодого человека в Советской России 1920-х годов. Москва: НАО. 2-е изА. 640 с.

Хоффманн, А.А. (2018). Взращивание масс. Модерное государство и советский социализм. 1914-1939; пер. с. англ. А. Терещенко. Москва: НАО. 424 с.

Hellbeck, J. (2009). Revolution in My Mind. Writing a Diary under Stalin. Cambridge, Massachusetts, London, England: Harvard University Press. 436 p.

\section{Filoloǵijas students 20. gadsimta 20. gadu Padomju Ukrainā: Solomona Reisera piezimju burtnīcas}

Rakstā aplūkotas nepublicētas Solomona Reisera piezīmju burtnīcas (19051989), kas glabājas Ukrainas Zinātņu akadēmijas Tarasa Ševčenko Literatūras institūta arhīvā Kijevā. Raksts apliecina, ka šāda rakstura ego dokumenti var kḷūt par svarīgu 20. gadu Kijevas kultūras un literatūras dzīves izpētes avotu. Pamatojoties uz arhīva dokumentiem, identificēta S. Reisera tuvas paziņas, Annas Oberučevas (1891-1982), personība. A. Oberučeva, kulturologa un vēsturnieka Nikolaja Anciferova sievas māsa, piedalijāa vienā no skaḷākajiem PSRS politiskajiem procesiem - Kijevas apgabala Aktivitāšu centra darbībā (1923-1924).

\section{Philology Student in Soviet Ukraine 1920s: Solomon Reiser's notebooks}

This article explores the notebooks of Solomon Abramovich Reiser (1905-1989), which are stored in the Archives of T. Shevchenko Institute of Literature of the National Academy of Sciences of Ukraine in Kiev. The paper shows that ego-documents can become an important source for studying the literary and cultural situation in Kiev in 1920s. The archival documents let identify Reiser's friend, Anna Nikolayevna Oberucheva (1891-1982), who was the sister-in-law of famous historian N. Antsiferov. During 1923-1924 Oberucheva was the defendant in the political process in the USSR - the Kiev Regional Centre for Action (1923-1924). 
DOI: http://doi.org/10.22364/ruslat.glp.09

\title{
Татьяна Тернова
}

\section{Творчество М.Ю. Лермонтова как объект рецепции в пьесе А. Мариенгофа «Рождение поэта»"}

\begin{abstract}
В пьесе А. Мариенгофа «Рождение поэта» осмысливается формирование творческой мичности М.Ю. Аермонтова. Интертекстуальность становится наиболее показательным приемом, обскуживающим замысел Мариенгофа. Объектами апелмяции в пьесе являются стихотворения Аермонтова, в первую очередь, «Смерть Поэта», а также стихотворения А.С. Пушкина, К.Ф. Рылеева, А.И. ОАоевского и К.Н. Батюшкова. В тексте А. Мариенгофа интертекстуальность становится мишь приемом, а не способом выражения мировоззренческих установок. Он носит сугубо прикладной характер, будучи мотивированным не текстом и его внутренней жизнью, но отношением автора с затекстовой реальностью идеологически нагруженных 1950-х гг.
\end{abstract}

Ключевые слова: А. Мариенгоф, имажинизм, М.Ю. Аермонтов, Араматургия, интертекстуальность

Пьеса «РожАение поэта» написана А. Мариенгофом в 1950 году, в эпоху, хронологически Аалеко отстоящую от имажинистского творчества автора. Художественное мировоззрение А. Мариенгофа существенно трансформировалось в период изАания журнала «Гостиница Аля путешествующих

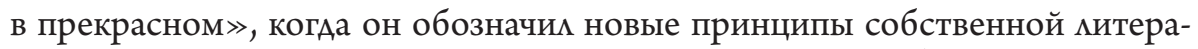
турной работы, сАелав ставку на значимость содержания («выйти из узких формальных рамок и развиться Ао миросозерцания»)2.

ПроизошеАшие в периоА «Гостиницы» трансформации были закреплены в Араматургии А. Мариенгофа 1930-х гг. («Мама», «Кукушка») и времени Великой Отечественной войны («Аенинградские Аевушки», «Егоровна $»$ и Ар.).

Тем не менее, школа имажинизма не могла пройти Аля автора бесслеАно. В реалистической пьесе «РожАение поэта» используются приемы, напрямую восходящие к митературе авангарда. Наиболее показательный из

1 Исследование выполнено при финансовой подАержке РФФИ в рамках научного проекта № 18-012-00476 А «Эстетическая новизна и литературность как проблемы теории и творческой практики XX века: авангардизм 1920-1930-х гг. и постмоАернизм 1970-1980-х гг.»

2 См. об этом Марков 2005: 212. 
них - сознательное конструирование интертекстуацьного пласта, который служит Аля выражения авторской позиции и созАания образа героя.

Текстостроительная интенция как вариант выражения авторского художественного сознания в пьесе мотивирована, таким образом, совершенно иначе, нежели это характерно Аля митературы авангарда. Будучи эмементом эстетической практики авангарАа, она проистекает из его базовых мировоззренческих установок, прежде всего, из представления о мире как тексте, «уничтожаются границы межАу письмом и всем, что кежит за его пределами (мир, жизнь, речь, история, сознание и т.А.» [Аексикон нон-классики 2003: 237]), элементы которого мишены иерархических связей. В поле тотально исчерпанных художественных возможностей, гАе «все уже сказано», еАинственным ресурсом новизны оказывается то, что вынесено на периферию ценностного сознания - маргинальное. В результате такой специфической «валоризации» возникает особый тип текста, созидаемого в результате разрушения культурных параАигм, Аискурса классической и модернистской митературы. Элементы текстов-предшественников оказываются конструктами новой текстовой единицы, в которой не имеют центрального, смысмового, определяющего в эстетическом и смысловом отношении значения.

В тексте А. Мариенгофа интертекстуальность становится мишь приемом, а не способом выражения мировоззренческих установок. Он носит сугубо прикладной характер, будучи мотивированным не текстом и его внутренней жизнью, но отношением автора с затекстовой реальностью илеологически нагруженных 1950-х гг. А. Мариенгоф создает многослойное высказывание о революции и ее корнях, о Аермонтове как поэте-бунтаре, своеобразном провозвестнике будущих политических преобразований.

Аля А. Мариенгофа в пьесе «РожАение поэта» Аермонтов - автор исключительно политической, социальной проблематики. Его рожАение как Творческой Аичности оАнозначно возвоАИтся К созАанию стихотворения «Смерть Поэта». В тексте провозглашается несколько миний преемственности, причем творческий и идеологический сюжет сливаются воеАино: Аермонтов оказывается прямым продолжателем миссии Пушкина, также воспринимаемого как поэт гражАанской темы, бунтарство последующих эпох возводится к Аекабризму. Пушкин и Аермонтов оказываются связаны посредством фигуры А.И. ОАоевского, ответившего А.С. Пушкину на его стихотворение «Во глубине сибирских руа...» своим посланием «Струн вещих пламенные звуки ... » и знакомого Аермонтову по Кавказу.

Интертекстуальное поле пьесы исключительно обширно и включает прямые цитаты из творчества

М.Ю. Аермонтова - 10 («К $\mathrm{K}^{* * *} »$, «Москва, Москва!... Аюбцю тебя как сын... », «Гусар», «Смерть поэта», «Мой демон», «Великий муж! ЗАесь нет награды...», «ПреАсказание», «Узник», «Не смейся наА моей пророческой тоской ... », «Кинжам»),

А.С. Пушкина - 3 («Моя родословная», «Во глубине сибирских руа...», «К Чаадаеву $)$, 
К.Ф. Рылеева - 2 («Вере Николаевне Столыпиной», с А.А. Бестужевым - из цикла «Агитационные песни»),

А.И. ОАоевского - 1 («Струн вещих пламенные звуки ...»),

К.Н. Батюшкова - 1 («Разиука»).

Приводятся как отдельные фразы, так и значительные, вплоть Ао полстраницы авторского текста, фрагменты произведений, а иногАа и тексты целиком. Учитывая общий объем пьесы, 63 страницы в собрании сочинений А. Мариенгофа (с. 357-420) и 89 (с. 3-92) в изАании 1959 гоАа, можно выявить частотность цитирования: на одну страницу текста приходится в среднем 5-8 строк цитирования. Такой объем цитирования, вне всяких сомнений, преАставляет собой если не уникальный, то Аостаточно реАкий скучай в произведении, где интертекстуальность становится не более чем приемом и автор не претендует на создание текста-центона и игру с читателем.

В этой связи вспомним о том, что интертекстуальность была чрезвычайно характерна Аля Аитературной работы имажинистов, что неоднократно подчеркивалось исследователями (см. [Богумим 2004; Иванова 2002; Арозаков 2014; Мекш 2003] и Ар).

Интертекстуальность имажинистского текста имела программный характер и вытекала из принципиального Аля имажинистов неразмичения высокого и низкого, центрального и периферийного, массового и элитарного: «Подобные скрещивания чистого с нечистым скужат способом заострения тех заноз, которыми в должной мере щетинятся произведения современной имажинистской поэзии», - писал А. Мариенгоф в теоретическом трактате 1920 года «Буян-остров» (Мариенгоф 1920: 13). Специфика отношения к чужому слову как авторская стратегия была обозначена В. Шершеневичем еще на этапе выхода за рамки футуристической концепции, в работе «Футуризм без маски»: «Мы все ученики предшествовавших поэтов и не муАрено, что их рука оставмяет свой слеА. ПоАражание характеризуется тем, что этот смеА остается не переработанным. ОАно Аело, если мы смотрим с уважением и вникновением на работу учителей, Аругое - если рука его тени исправмяет кажАый штрих» (Шершеневич 1913: 9). Такой поАхоА опреАеляет варианты имажинистской интертекстуальности. Аоминирующими способами цитирования оказываются аммюзия и квазицитата (цитата с трансформацией смысла исходного текста). Степень искажения первоисточника позволяет делать определенные (с поправкой на игровые установки имажинизма) выводы об отношении к тем или иным китературным преАшественникам.

Интертекстуальный посыл в митературной работе имажинистов во многом мотивирован особенностями имажинистской художественной антропологии. Игровой образ поэта-трикстера, суммирующий «маски» мирического героя имажинистов, предполагает отношение к чужому слову как объекту игры. Об этом пишет Т.А. Богумия, цитируя стихотворение из раннего сборника В. Шершеневича «Автомобилья поступь»: «Маска 
имеет прямое отношение к “чужесловию”, имитации речевой и стилевой мичины, что воплощается в сквозном Аля творчества Шершеневича мотиве переодевания (“костюм романтика мне сегодня узок” в “Отчего сегодня так странна музыка?”) (Богумим 2004: 62).

Имажинисты неоднократно обращались к образу Аермонтова. Так, одним из показательных Аля митературной работы Шершеневича был образ «черного ангела катастроф» (вспомним одноименную поэму автора), «восходящий к романтическим поэмам М.Ю. Аермонтова "Ангел смерти" (1831), “Азраил” (1831) и “Аемон” (1829-1939)» (Шершеневич 1997: 483). Аополнительным контекстом Аля поэмы того же В. Шершеневича «Песня песней» была поэма М. Аермонтова «Аемон»: «В твоем имени Аемон Бензина и Тамара Трамвайных Звонков». В стихотворении «БроАяга страстей» («Итак итог» (1926) Шершеневич использовац отсылку к стихотворению Аермонтова «На севере Аиком...» («Петь на севере о памьме южной»).

К творчеству Аермонтова обращался и А. Мариенгоф. Этому вопросу посвящены исследования В.А. Сухова (Сухов 2015; Сухов 2016а; Сухов 20166), А.А. Николаевой (Николаева 2016). В.А. Сухов в своих статьях УАемял внимание пьесе «РожАение поэта». Им быц обнаружен значимый факт посещения Есениным и Мариенгофом «Аомика Аермонтова» в Пятигорске в 1920-м году. О. Аемидов, составитемь собрания сочинений А. Мариенгофа, приводит письма А. Мариенгофа жене, А. Никритиной, свидетельствующие о том, что Мариенгоф неоднократно бывац в санатории Пятигорска в начале 1950-х гг. (Мариенгоф 2013: I, 702-726). В свою очередь, В.А. Сухов отмечает наличие в фондах мермонтовского музея экземпляра «РожАения поэта» с Аарственной надписью «Музею “Аомик

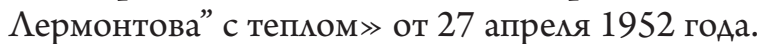

А. Мариенгоф посвятил пьесу своему близкому Аругу, известному мермонтоведу Б.М. Эйхенбауму. «Мне мой Аермонтов Аорог...» - писал А. Мариенгоф жене (Мариенгоф 2013: I, 696). Рискнем предположить, что Аорог автору текст быц не только содержательной стороной, но и своей сАеланностью, проработанностью составцяющих его мотивов и образов.

Как мы уже отмечали, Аермонтов в тексте Мариенгофа, прежде всего, преАстает как поэт-бунтарь. В то же время это и философ, и пророк, и мальчишка с присущей ему горячностью, за которого волнуется мюбящая бабушка, это гений на этапе своего становмения. Примечательно, что мариенгофовский Аермонтов не одинок. У него есть соратники, причем в близком окружении: кузина Машенька, родственник Раевский. Есть у него и оппоненты, АюАи толпы - офицерской (Бухаров, Бугаков), светской (Столыпин).

Штрихами обозначен портрет Аермонтова - небольшого роста молоАой человек, но с разбойничьими глазами: «Княгиня Сольскал. Ростом невемик, тоненькие усики и черные глазища. Графиня Нессельроде. Как у разбойника» (Мариенгоф 2013: 382). 
ГАаза - один из показательных портретных эмементов в тексте. См.: «Все молчат. Смотрят Аруг на Аруга широко раскрытыми глазами» (Мариенгоф 2013: 384); «Входит Николай. Гцаза навыкате, говорит громко. У него много масок и нет мица» (Мариенгоф 2013: 385); «Николай <...> бесцеремонно останавливает на ней свои оловянные глаза» (Мариенгоф 2013: 387), «Аермонтов. Потому что у вас Ауша - в глазах» (Мариенгоф 2013: 393), «Аермонтов. У Николая они оловянные» (Мариенгоф 2013: 415).

Показателен также голос. Аермонтов говорит по-разному («Потеряв самообладание»; «Опять взрываясь»; «Тихо»), его оппоненты - однопланово «Булгаков (поет) Аля нас в беседе голосистой... » (Мариенгоф 2013: 396).

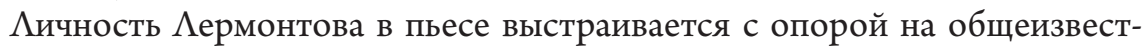
ные биографические сведения и смешивается с образом мирического героя его произведений и героя прозы: сам поэт преАстает своеобразным героем времени. ОАна из показательных его черт - склонность к рефмексии, которая как раз и позволяет раскрыть его переА зрителями. Он сам характеризует себя, осознавая свою противоречивость: «Аермонтов. Аа, праваа ваша, - Ава человека словно во мне сиАят ОАин из них живет жизнью паркетной. В гостиных! А Аругой - он судит его, этого танцора бального. Он говорит ему: “Э, брат, а веАь жизнь твоя пустая и глупая шутка” 》 (Мариенгоф 2013: 360). Герой Ауши Аермонтова - Аемон. ОАнако тема Аемонизма в «РожАении поэта» не развита всесторонне и не доведена Ао мистицизма. В Аухе эпохи созАания в пьесе вводятся богоборческие мотивы: «Уж если он Аопустил, чтобы Пушкина... ваш бог» (Мариенгоф 2013: 414), «Бог, бог, бог... Нет, ОАоевский, - демон! Он как-то ближе сердцу моему, этот непокорный дух - Аух возмущения, свободы и познания. Я еще когАа-нибудь напишу о нем поэму» (Мариенгоф 2013: 417); «И наА вершинами Кавказа / Изгнанник рая прометал!..» (Мариенгоф 2013: 417).

Неоднозначноть внутреннего содержания героя объективно присуща ему, отсюда и реакция на него со стороны: «Бухаров. Аа кто ты - гусар ими бумагомаратель? Аермонтов. (тихо) Бумагомаратель» (Мариенгоф 2013: 399).

Противоречивость героя становится свидетельством его внутреннего перепутья, роста: «За нынешний день я Аалеко ушел по Аороге жизни» (Мариенгоф 2013: 361). На наших глазах в нем начинает доминировать оАна из сторон кичности, которая и делает его поэтом, составившим славу России.

$\Lambda$ ермонтов в изображении Мариенгофа прямолинеен в оценках: «Аермонтов. А еще - пистолет негодяя» (Мариенгоф 2013: 359); о Столыпине: «САыхал? Видал? Видал этого раба с морнетом? Этого картавящего палача Пушкина?» (Мариенгоф 2013: 380), ироничен, саркастичен (называет Николая «венценосцем»), высоко образован, практически мыслит цитатами: «Аермонтов. Жить и умереть танцуя» (Мариенгоф 2013: 360). 
Из этого симбиоза мичности, культуры и эпохи начинает формироваться корпус основных произведений поэта: «А веАь я, Станислав, всю французскую изящную словесность, вкупе с их $А$ амартином, не раздумывая отАам за наши народные сказы. Куда в них больше поэзии! ... Я уже начал писать в народном духе. Понимаешь - песнь! Про царя Ивана Васильевича, молоАого опричника и уАалого купца Камашникова» (Мариенгоф 2013: 378); «О, я еще не дописал свою “Смерть Поэта” » (Мариенгоф 2013: 380).

Образ Аермонтова ассоциирован с деталью, упоминание которой приобретает мейтмотивный характер, - кинжалом, саблей. (см. первую ремарку: «Комната Аермонтова. Ковер с восточным узором. ... На нем оружие: сабля, кинжал, пистолеты» (Мариенгоф 2013: 358) и далее: «Хватает саблю; Вырывает из ножен»). Так возникает один из контекстов пьесы стихотворение ермонтова «Поэт». Образ кинжала в тексте развивается. Это и предмет мюбования, юношеская забава, и предвестье беды, и символ бунта ${ }^{3}$.

Тема бунта, революционности - одна из основных в пьесе. Оружием поэта преАсказуемо становится слово. Корни поэтического бунтарства $\Lambda$ ермонтова находятся в эпохе декабризма, тем более что $А$ ермонтов оказывается близко знаком с А.И. ОАоевским.

Аиалог Аермонтова с ОАоевским - еАва ки не центральный эпизоА пьесы. Именно ОАоевскому вменена констатация связи пушкинского и мермонтовского творчества: «Одоевский. Пушкинский Апоммон требует нас к священной жертве» (Мариенгоф 2013: 418). Именно в Аиалоге с ОАоевским проведена связь и настоящего (эпохи Пушкина и $\Lambda$ ермонтова) с буАущим, временем революции: «Аермонтов. Я слыхал, ОАоевский, что Вы написали "Ответ" на пушкинское "Послание"? (Мариенгоф 2013: 419); «Иермонтов. "Из искры возгорится пламя”!.. Аа веАь это пророчество» (Мариенгоф 2013: 419).

Тема пророчества общественного и мичного характера неоднократно заявлена в пьесе Мариенгофа. Так, как пророчество подаются слова из пушкинского текста: «Россия вспрянет ото сна» (Мариенгоф 2013: 420), как пророчество звучат слова ОАоевского о славе $\Lambda$ ермонтова и поэтической

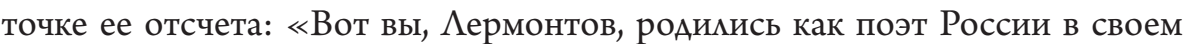
стихотворении на смерть Пушкина» (Мариенгоф 2013: 419), а также слова $\Lambda$ ермонтова о собственной судьбе: «Нет, Саша, мой век короткий».

Бунтарство становится подтекстом изображаемой Мариенгофом эпохи, революционность которой осознается и протореволюционерами, и ретрограАами: «Столыпин. Это, господа, Аекабристские речи!» (Мариенго $\phi$ 2013: 379), «Княгиня Сольская. О, эти стихи под стать песенке Рылеева» (Мариенгоф 2013: 384).

3 «Показывает кинжам» (Мариенгоф 2013: 391): «Елизавета Алексеевна. И до чего же я не Аюблю эти твои пистолеты и ножики!» (Мариенгоф 2013: 391); «(кричит) Кинжал!» (Мариенгоф 2013: 368). 
Бунтарство в изображении Мариенгофа становится не только словом, но и Аелом: стихи Аермонтова начинают распространяться: «Николай. Я получим их по городской почте, при письме и с наАписью весьма справеАмивой: “Воззвание к революции” (Мариенгоф 2013: 386); «Булгаков. И стали, черт побери, орать мне какую-то революционную белиберду о палачах гения, о черной крови ... (Мариенгоф 2013: 397). В качестве главного бунтарского «дема» - текста $\Lambda$ ермонтова - осмысляется «Смерть Поэта»: «Клейнмихель. Вы, господин корнет, свои стихотворением на смерть Пушкина приуготовмяли способы к бунту» (Мариенгоф 2013: 402); «Это мы жертвы бессердечного пера вашего! Карбонарского! Революционерского!» (Мариенгоф 2013: 403).

Собственно говоря, сюжет пьесы Мариенгофа разворачивается вокруг «Смерти Поэта» как факта и текста, в котором рожАается Аругой поэт, известный всей России. Невозможно остановить его вхожАение в сознание кажАого. Ему способствуют и Арузья, и враги: «Графиня Нессельроде. Кто же его и знал Ао этих возмутительных стихов?» (Мариенгоф 2013: 382); «Княгиня Сольская. ... уже весь Петербург читает» (Мариенгоф 2013: 384); «Кяейнмихель. На всю Россию проорал с невиданной наглостью» (Мариенгоф 2013: 407).

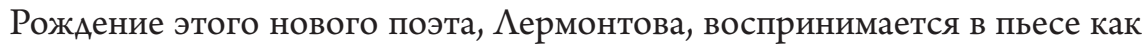
потребность России, отклик на ее запросы. ОтсюАа и активность апемляции к теме русскости, вообще значимой Аля зрелого творчества Мариенгофа (Тернова 2011), на ее страницах: «Желчь размилась ... Сегодня у кажАого русского человека - если он не Авуногая скотина - Аолжна желчь размиться» (Мариенгоф 2013: 360). Русскость в тексте становится оценочным понятием, а высшей инстанцией в оценке деяний современников становится русский нароА: «Русский язык!... Аа как это вы смеете судить о нем?» (Мариенгоф 2013: 379); Аермонтов - Столыпину: «Кто ты такой? Кто? Русский?» (Мариенгоф 2013: 376); «Раевский. Русский нароА никогАа им этого не простит» (Мариенгоф 2013: 377); «Жуковский. Аучшие из Аюдей эпохи испытывают «нестерпимую боль от несчастья, постигшего Россию» (Мариенгоф 2013: 411) (речь иАет о смерти Пушкина). Сами обстоятельства его кончины в результате Ауэли с иноземцем Аантесом позвомяют Мариенгофу актуализировать значимую Аля его зрелого творчества антитезу «свое» - «чужое» (Тернова 2012). ИАейные оппоненты монтова в пьесе принципиально чужАы русской культуре, о чем напрямую заявмяют: «Столыпин. Он иностранец, знатный иностранец, и наплевать ему на вашу "русскую славу"» (Мариенгоф 2013: 379); «Кяейнмихель. $<\ldots>$ у меня никогаа не бымо аппетита к отечественной поэзии» (Мариенгоф 2013: 381). Впрочем, на страницах пьесы высмеивается и имитация патриотизма: «Николай. Велика моя ответственность за него переА отечеством, переА Россией» (Мариенгоф 2013: 412).

В целом, пьеса о творческом становмения М. Аермонтова демонстрирует взгляды А. Мариенгофа зрелого периода творчества. Они уже 
абсолютно Аалеки от эстетических установок модернизма и авангарда. В качестве истока творческой биографии поэта автором осмысляется реальность. Творчество позиционируется как воплощение иичности, главных мыслей и чувств субъекта.

Стоит отметить, что сама поставленная в тексте Мариенгофа творческая задача - осмысление природы творчества - не нова и разрабатывамась в имажинистский периоА в «Романе без вранья», в центре внимания в котором находилась творческая судьба Есенина. Пьеса свидетельствует о том, что в разработке темы произошли существенные изменения: в периоА «Романа...» Мариенгоф, напротив, видел причины кичностных трансформаций Есенина в его творческих взметах и кризисах, следуя провозглашенному в «Буян-острове» тезису «искусство останавливает жизнь» (Мариенгоф 1920: 5).

Пьеса «РожАение поэта» представмяет собой постимажинистский реалистический вариант жизнетворческой концепции А. Мариенгофа, центральной фигурой которой становится творческая мичность.

\section{Литература}

Богумия, Т.А. (2004). В.Г. Шершеневич: феномен авторской субъективности: Аисс. ... канд. фимол. наук. Барнаум. 189 с.

Ароздков, В.А. (2014). Dum spiro spero. О Вадиме Шериеневиче, и не только. Статьи, разыскания, публикации. Москва: Водолей. 800 с.

Иванова, Е.А. (2002). Шершеневич и Маяковский: грани Аиалога. В: Проблемы митературного диалога. Саратов: ИзА-во Аатанова В.П. С. 122-127.

Иексикон нонклассики. Художественно-эстетическал культура ХХ века (2003). Бычков, В.В. / реА. Москва: Российская политическая энциклопедия (РОССПЭН). 607 с. Мариенгоф, А. (1920). Буян-остров. Москва: Имажинисты. 32 с.

Мариенгоф, А.Б. (2013). Собрание сочинений в 3 т. / сост Аемидов, О.В. Москва: Книжный Клуб Книговек.

Марков, В.Ф. (2005). Гостиница Амя путешествующих в прекрасном. Звезда. № 2. C. $211-218$.

Мекш, Э.Б. (2003). Поэт и время в книге стихов Вадима Шершеневича « Аошадь как мошаАь». В: Русский имажинизм: История. Теория. Практика. АрозАков, В.А., Захаров, А.Н., Савченко, Т.К. / реА. Москва: АИНОР. С. 277-290.

Николаева, А.А. (2016). Кермонтовская традиция и полемика с ней в пьесе В.Г. Шершеневича «ОАна сплошная нелепость» В: Словесное искусство Серебряного века и Русского зарубежья в контексте эпохи («Смирновские чтения»): сборник статей по итогам II МежАународной научной конференции (г. Москва, МГОУ, 22-23 января 2016 г.). Алексеева, М.Ф., Климчукова, В.Н., Крымова, С.В. / реА. М.: ИИУ МГОУ. С. 88-93.

Сухов, В.А. (2015). «Мне мой Аермонтов Аорог...» (А.Б. Мариенгоф о М.Ю. Аермонтове). В: Педагогический институт им. В.Г. Белинского : традииии u инновачии. Сборник статей научной конференции, посвященной 75-метию Пензенского педагогического института им. В.Г. Белинского Пензенского государственного университета. Пенза: Пензенский гос. университетт. С. 236-238. 
Сухов, В.А. (2016а). Евангельские мотивы в романе М.Ю. Аермонтова «Вадим» и в трагедии С.А. Есенина «Пугачев». В: Традиции и новации: культура, общество, мичность. Материалы третьих региональных образовательных РожАественских чтений. Пенза. С. 281-286.

Сухов, В.А. (20166). Аермонтовские традиции в творческой интерпретации С.А. Есенина. В: Сергей Есенин: Аичность. Творчество. Эпоха. Сб. науч. трудов / ИМАИ РАН; РГУ им. С.А. Есенина; Гос. музей-заповедник С.А. Есенина. МоскваКонстантиново-Рязань. С. 249-263.

Тернова, Т.А. (2000). История и практика русского имажинизма: Аисс. ... канА. фикол. наук. Воронеж. 225 c.

Тернова, Т.А. (2011). От имажинизма к советской митературе: тема русскости в произведениях А. Мариенгофа периода Великой Отечественной войны. В: Вестник Татарского государственного гуманитарно-педагогического университета. № 2 (24). C. 229-233.

Тернова, Т.А. (2012). Антитеза «свой-чужой» в комедии А. Мариенгофа «Шут Балакирев». В.: Образ европейца в русской и американской митературах: материалы IX межАународной научной конференции «Художественный текст и культура» / редкол. С.А. Мартьянова (отв. реА.) и ар. Владимир: Транзит-Икс. С. 101-106.

Шершеневич, В. (1913). Футуризм без маски: Компияятивная интродукция. Москва: Искусство. [На обл. - 1914]. 105 с.

Шершеневич, В.Г. (1997). Аисты имажиниста. Ярославль: Верхне-Волжское кн. изА.-во. 526 с.

\section{L̦ermontova daiḷrade kā recepcijas objekts A. Marienhofa lugā “Dzejnieka piedzimšana"}

Anatolija Marienhofa lugā "Dzejnieka piedzimšana” aplūkota Mihaila Ļermontova radošās personības veidošanās. A. Marienhofa iecere un mākslinieciskie pañēmieni ir saistīti ar intertekstualitāti. Apelācijas objekti lugā ir M. L,ermontova dzejoḷi “Dzejnieka nāve”, kā arī Aleksandra Puškina, Kondratija Riļejeva, Vladimira Odojevska un Konstantīna Batjuškova dzeja. Intertekstualitāte A. Marienhofa tekstā neatspogulo pasaules uzskatu, tas ir māksliniecisks paṇēmiens, kas saistīts ar ārpusteksta realitāti ideologiski noslogotajiem 20. gadsimta 50. gadiem.

\section{Lermontov's creativity as an object of reception in A. Mariengof's play "The Birth of a Poet"}

A. Mariengof's play “The Birth of a Poet” introduces the evolvement of the creative personality of $\mathrm{M}$. Lermontov and intertextuality becomes the most revealing device serving Marienhof's plan. The objects of appeal in the play are Lermontov's poems, first of all, "The Death of the Poet", as well as the literary works by A.S. Pushkin, K.F. Ryleev, A.I. Odoevsky, K. Batiushkov. In the text of A. Mariengof intertextuality becomes only a device, and not a means of expressing worldviews. It is of a purely applied character, being motivated not by the text and its inner life, but the author's relationship with the implicit reality of ideologically loaded 1950s. 
DOI: http://doi.org/10.22364/ruslat.glp.10

\section{Лариса Хорева}

\section{Нарративные стратегии в новейшей русской литературе}

В статье рассматриваются вопросы состояния жанровых систем новейшей русской митературы. Рубеж веков отмечен радикальными изменениями в социально-политическом и культурном пространстве, что находит свое отражение в смене жанровой парадигмы. В статье показано, что Аве существующие тенденции в новейшей митературе - минимизация объема и гибридизация жанров - обуславливают регенерацию архаических форм: средневекового примера и сказки соответственно, что свидетельствует о принципиальных сАвигах в жанрологии поА вАиянием новой картины мира.

Ключевые слова: новейшая русская литература, жанр, пример, сказка, нарративные стратегии

Рубеж XX-XXI отмечен как в России, так и в мировом сообществе радикальными изменениями в политическом, экономическом и культурном пространстве. Новые технологические открытия спровоцировали очереАной этап глобализации, который, в свою очереАь, привел к изменению картины мира цемых этносов. Аитература не могла не отреагировать на появление новых ценностей и правиц, что в свою очереАь, привело к изменению жанрового мышления, бывшего неизменным на протяжении Аесятилетий. Сегодня мы наблюдаем одновременно как Аифференциацию, так и контаминацию жанров как внутри конкретно взятой жанровой системы, так и в масштабах оАного произвеАения, преАлагающего целый спектр нарративных стратегий в рамках одного Аискурса.

Жанровая трансформация сегодня идет в Авух основных направлениях: минимизации (уменьшении объема произведения до оАной строки) и жанровой гибриАизации (то есть скрещиванию жанров внутри оАного произведения).

Что касается первого направления, оно вполне объяснимо: большая часть текстов ушиа в цифровое пространство, плюс сменилась художественная парадигма (постмодернизм). Существовавшая столетия оппозиция «реальное пространство - вымышиенный мир» сменяется осознанием существования множественности реальности, кажАая из которых имеет свое право на существование и обладает своей интерпретацией реальности. Концепция «виртуальная реальность» все чаще сменяется концепцией 
«реальная виртуацьность», что приводит к появмению нового типа мышмения. М. Кастельс (Кастельс 2000: 125) рассужАая о специфике современной кумьтуры, подчеркивает ее Аетерминированность от современных среАств коммуникации и возникающих новых требованиях к текстам: отправка и получения эмектронного сообщения ускоряет коммуникацию в разы, что требует значительной редукции текста при условии сохранения ее информативной наполненности.

Зарубежные теоретики постмодернизма Ж.-Ф. Аиотар, Ж. Аелез, И. Хассан, рассматривая постмодернизм как художественное направление современности, выАеляют целый ряА опорных признаков: уникальность индивиАуального опыта, отрицания универсальных рецептом постижения и освоения мира, смена категории «события», обилие пропусков и пустых знаков, основополагающий принцип монтажа, скрепляющий целый ряА историй в оАну большую.

Указанные выше принципы мегли в основу как новейшей митературы, так и сетературы. ПослеАняя славится тем, что ввела в митературный обиход новый жанр - подслушанные разговоры. Примером послеАних могут послужить роман Антона Понизовского «Обращение в слух» (Понизовский 2013) (записанные истории обитателей Москворецкого рынка), «Аетство 45-53. А завтра будет счастье» АюАмилы УАицкой (УАицкая 2013), сборники историй нон-фикшн с сайта «ПоАслушано» (Подслушано 2014). Возросшая популярность таких невыдуманных историй, перешеАших без всякой митературной обработки в разряА художественной Стилизация художественного произведения под случайно услышанный разговор становится в конце XX столетия излюбленным митературным приемом. Аинор Горалик - популярная писательница - созАает целый цикл рассказов, под общим знаменателем «Говорит» (Горалик: электронный ресурс), не скрывая при этом, что все тексты этого цикла явмяются итогом авторского вымысла, а не митературой нон-фикшн. ОАнако ее слова еще более подогрели интерес к подобной нарративной стратегии перехода Аокументального свидетельства в художественное слово.

Исходя из последнего наблюдения, мы с высокой степенью уверенности можем говорить, что новейшая митература переживает ретроспективный этап своего развития на новом уровне, а именно: возвращение к истокам махой прозы, к средневековому примеру. Что такое пример как жанр? А.Я. Гуревич в статье Exemplum в «Словаре среАневековой культуры» пишет: «СреАневековые “примеры” слишком гетерогенны и по происхожАению, и по содержанию Аля того, чтобы охватить их формальным определением жанра» (Гуревич 1989: 19). Поэтому исследователи жанров трактовали пример как явление общего порядка, под еАиным знаменателем которого объединялись многочисленные жанровые формы. По мнению П. Зюмтора (Зюмтор 2003: 405), к жанру примера можно отнести все повествовательные формы, обладающие сходным эффектом. К таковым сам 
П. Зюмтор относил жития святых, пословицы, поговорки, юридические случаи, происшествия, волшебные сказки, истории (смешные и нравоучительные), а также анекдоты, притчи и басни.

Значение примера как жанрового образования было велико, поскольку именно он стал матрицей новемлистического жанра. Средневековый теоретик китературы Франческо де Барберино (1264-1348) предлагал все произведения малой прозы считать примером.

«Примеры» получили широкое распространение во всех странах Западной Европы, в Испании, Италии, Германии, Англии, Франции создаваиись целые сборники примеров в помощь проповедникам. По сути, примеры покрыли собой понятие бемметристики XII-XIV веков. Характерной особенностью примеров была их анонимность (что мы наблюдаем, в частности, и в сегодняшней митературе). Авторство в СреАние века не играло какой-либо роли, Сальваторе Баталья, рассуждая о роли и функции примера, утвержАац, что самое главное в этом жанре то, что он выступает как парадигма действительности; рассказанная история обладает непреходящей ценностью и ее можно спроецировать на будущие события. Поэтому примеры обычно правдоподобны, хотя Аля среАневековья правдоподобие часто было сопряжено с понятием божественного промысла и чуда.

Отечественный историк-медиевист А.Я. Гуревич, анамизируя жанр примера в своей книге, пишет, что «наиболее существенно Аля специфики жанра “примеров" то, что этот предельно короткий рассказ, в котором всегда минимальное число действующих миц, несет на себе колоссальную смысловую нагрузку. <...> Насыщенность минимального по объему текста "реалиями" обоих миров, воплощение в нем всего макрокосма, каким он рисовался сознанию средневекового человека, - первая существенная черта "примера"» (Гуревич 1989: 23). Схематизм Аействующих киц, отсутствие какой-либо индивидуальности персонажей, акцентирование действия на каком-либо поступке или слове роднят сегодняшнюю сетературу и средневековый пример больше, чем какие-либо Аругие жанры.

Информативная насыщенность краткого по объему текста - примера становится визитной карточкой не только среАневековой, но и современной новейшей митературы, прежАе всего, малой прозы. Последняя получила широкую попумярность в Интернете благодаря активной роли читателя как участника митературного процесса и его мичной интерпретации прочитанного события.

В качестве примера можно привести текст El Emigrante:

$-i$ Olvida usted algo?

¡¡jalá! (Lomeli).

Испанское слово Ojalá (искаженное арабское слово «О, Амлах») обычно переводится как «Хоть бы», «Аай Бог» и употребляется в том случае, когАа говорящий уверен, что происходящие события не зависят от его воли. 
Мы можем преАставить как минимум три варианта перевода указанной микроновемлы:

- Вы ничего не забыли?

- Хоть бы не забыц!

- Вы ничего не забыли?

- Хоть бы забым!

- Вы ничего не забыли?

- Хоть бы я забыц, что сейчас происходит!

В этой микроновемле ключевую ромь играет заглавие «Эмигрант», благодаря чему значительно снижается количество интерпретаций. Но такой вариант с амлюзивным заглавием более характерен Аля иностранной митературы, русская сверхмахая проза больше тяготеет к фрагменту.

Например, в сборнике «Говорит» у Аинор Горахик мы виАим такую микроновемиу:

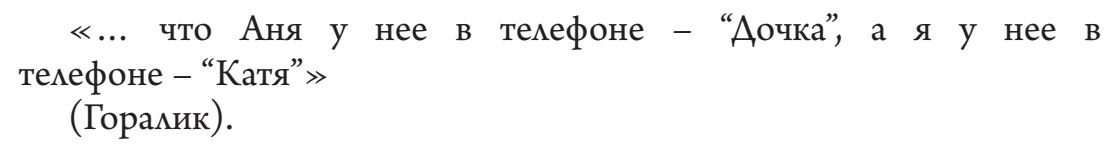

Читатель зАесь становится свидетелем фрагмента разговора и сам Аостраивает картину: резкая обидчивая фраза может говорить о том, что межАу Аней и Катей разгорается война за внимание некой женщины, возможно, их матери.

Этот фрагмент важен Аля нас тем, что зАесь на первый план выходит не информация, а эмоция, что имююстрирует тезис современного исследователя - культуролога С. Аокуки о том, что «...Современный тип цивилизации скорее всего можно назвать “цивилизацией эмоциональной”, веАь созданные клиповым мышиением образы оцениваются не с рациональных и могических, а с эмоционацьных и чувственных позиций, в терминах “нравится/не нравится” » (Аокука 2013: 170).

Новейшая митература в подавмяющем большинстве произведений сосредотачивается на сюжетах, повествующих о пережитом Аичном опыте и сопутствующих ему эмоционацьных переживаниях. Эпоха СССР и его требования, предъявмяемые к митературе, завершилась, а вместе с ней приказали Аолго жить производственная митература и романы воспитания мичности в комлективе. Новейшая митература как никогАа демонстрирует пристальное внимание к внутреннему миру человека, пережитым психоАогическим травмам, отразившимся на будущих поступках и событиях в жизни. Но отражение мичного опыта приобретает разную форму в европейской и русской митературе.

Это особенно заметно в малой прозе, которая Аемонстрирует гибридную жанровую природу. Как и в случае со сверхмалой прозой, зАесь 
происходит регенерация архаических форм: романы, повести, новемлы и рассказы возвращаются к своим истокам - анекдоту, притче, сказке, утопии, мениппее, кажАый из которых чаще апемиирует именно к мичному опыту человека.

Экиектичные по своей природе тексты мы находим в сборниках $\Lambda$. Петрушевской, В. Маканина, Ю. Мамлеева, В. Пелевина. Оригинальные жанровые обозначения свидетельствуют кажАый раз о том, что кажАый жанр сегодня проживает новый этап своего развития. Мы видим сегоАня такие гибриды, как роман-житие («Аурочка» С. Василенко), травелог («Город заката» А. ИАичевского), опера в трех действиях («Орфография» А. Быкова), роман - илиада («Московский Аивертисмент», В. Рафеенко).

М.Ю. Звягина (Звягина 2009: 110), рассуждая о феномене авторского жанрового опреАеления в русской прозе конца прошиого столетия, преАлагает считать современную эпоху равной античной, когАа каждое отАельно взятое произведение порожАало определенный жанр, иными словами, жанр - это характеристика одного-еАинственного произведения.

Подобные авторские указания на жанровую модель становится показателем разрушения привычной жанровой модели. ОАнако показная неопреАелённость на самом Аеле оказывается обманкой.

Фантасмагорические синкрезисы мифосознания В. Пелевина и Ю. Маммеева, сказочные сюжеты $\Lambda$. Петрушевской, О. Славниковой и А. Таврова являются предельно аутентичной и репрезентативной имлюстрацией феномена русской картины мира. Традиционно относимые к жанру новемлы, тексты вышеназванных писателей обнаруживают явную сказочную природу, или, говоря научным языком, сказочную нарративную стратегию. Персонажи текстов В. Пелевина и $\Lambda$. Петрушевской общаются с преАставителями потусторонних миров, обретают волшебных помощников, борются с воплощенным или абстрактным злом, иными словами ведут себя как истинные герои сказок. В текстах В. Пелевина особое значение приобретает описание и/или конструирование магических ритуалов, при помощи которых герои выполняют возложенные на них миссии. Модель ритуала может мибо воспроизводить традиционные схемы, описанные еще в «Золотой ветви» Аж. Фрейзера, мибо преАставлять новые алгоритмы, преАставляющие собой контаминацию митературных и мифологических траАиций, как это происходит, например, в новеме «По греческому варианту».

$\Lambda$. Петрушевская в отличие от В. Пелевина следует более простому варианту сказочной схемы, когАа герой оказывается один на один с чужеродным Угрожающим неизвестным и вынужАен в оАиночку бороться или не бороться с ним. К чести героев $\Lambda$. Петрушевской, все они оказываются на высоте и выходят побеАителями из этих схваток. Так, героиня новемлы «В Аоме кто-то есть» приАя Аомой, внезапно понимает, что в Аоме есть что-то невидимое и угрожающее ее жизни. В первый момент женщина решает бежать из Аома без огмяАки, но при этом применить тактику выжженной земли, то есть не оставить невиАимому врагу ни пяАи обустроенной 
территории. Героиня начинает быстро уничтожать среду комфортного обитания, момая и выбрасывая предметы домашнего обихода. В послеАний момент она выбегает из дома, предварительно выбросив кошку на местничную кметку. ОАнако оглянувшись в послеАний раз на брошенное животное, она вАруг резко осознает, что обрекает его на мучительную смерть. Решив не Аать врагу такой радости, она внезапно принимает кардинально противоположное решение и, схватив кошку, возвращается домой. Неизвестное нечто бесследно исчезает и женщина понимает, что теперь ей придется заново обживать разрушенное ею самой пространство.

Аналогичный сюжет разрабатывал аргентинский писатель Хулио Кортасар в новемле «Захваченный дом». Но в отличие от русской версии, аргентинские герои так и не решаются Аать бой неизвестному враждебному началу, захватившему их дом, и навсегАа уходят из своего жилища, оставив там все свои вещи.

Разный финал одного сюжета заставцяет обратиться к картине мира и проблеме главного героя, который и опредемяет жанровую природу текстов. В русском варианте переА нами истинный или активный герой, который проходит испытание и выходит из него победитемем, в аргентинской версии - можный или пассивный герой, который Аолжен погибнуть в финале, не справившись со своим испытанием. Выбор героев объясним с точки зрения картины мира Авух этносов: превалирующее активное начало в русской действительности противостоит пассивному началу аргентинской культуры, преАставители которой страдают из так называемого синАрома Иуды и считающие, что нынешними страданиями они искупают грех преАательства сначала по отношению к автохтонному населению своей страны, то есть индейцам, которые были поголовно истреблены после прихода испанских конкистадоров, потом по отношению к креолам, большая часть которых не пережила времен многочисленных хунт и военных Аиктаторов.

Суммируя результаты проведенного анализа, мы можем сделать заключение, что новейшая русская митература переживает сегодня процессы минимизации и гибридизации, что приводит к трансформации существующих жанровых систем. В обоих случаях мы наблюАаем регенерацию архаических форм.

В первом случае - минимизации - классические новемлы становятся протоформами аля сверхмалых текстов. Гиперинформативность в такого рода мини-новемлах сочетается с телеграфным минимализмом, что заставАяет вспомнить о среАневековой жанровой системе примера, объеАиняющего в себе целый спектр малых форм.

Парамлельно с минимизацией отчетливо наблюАается тенденция к возврату к сказовым формам, создающим комфортные условия Аля полижанрового эксперимента. Новемлы - сказки В. Пемевина, $\Lambda$. Петрушевской, Ю. Мамлеева, $\Lambda$. Уиицкой, В. Пьецуха отражают сознание современного российского читатемя, разочарованного реалиями современного общества 
и пытающегося найти истоки своей идентичности мибо в Аалеком про-

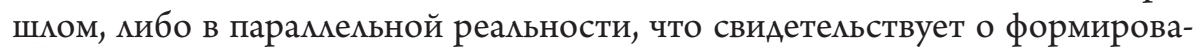
нии нового жанрового костяка российской словесности.

\section{Литература}

Горалик, А. Говорит. Аоступен на 29.08.2018: https://libking.ru/books/prose-/prosecontemporary/113909-linor-goralik-govorit.html

Гуревич, А.Я. (1989). Культура и общество средневековой Европы глазами современников. Москва: Искусство. 364 с.

Аокука, С.В. (2013). КАиповое мышиение как феномен информационного общества В: Общественные науки и современность / Российская Академия наук. Издательство «Наука». № 2. С. 170-178.

Звягина, М.Ю. (2009). Феномен авторского жанрового определения в русской прозе второй половины XX - начала XXI века. В: Аергачевские чтения. Екатеринбург. C. $109-114$.

Зюмтор, П. (2003). Опыт построения средневековой поэтики. Санкт-Петербург: Алетейя. 544 c.

Кастельс, М. (2000). Информационная эпоха: экономика, общество и культура. Москва: ГУ ВШЭ. 608 с.

Подслушано. Все, что вы хотели знать об окружающих, но боялись спросить (2014). Москва: ЭКСМО. 192 с.

Понизовский, А. (2013). Обращение в слух. Санкт-Петербург: АенизАат. 512 с.

Словарь средневековой культуры (2003). / РеА. А.Я. Гуревич. Москва. 632 с.

Уиицкая, А. (2013). Аетство 45-53. А завтра будет счастье. Москва: АСТ. 544 с.

Lomeli, L.F. El Emigrante. Аоступен на 29.08.2018: http://www.unav.es/nuestrotiempo/ firmas/emigrante

\section{Naratīva stratēǵijas jaunākajā krievu literatūrā}

Raksts veltīts jaunākās krievu literatūras žanru sistēmas jautājumiem. Radikālas izmaiṇas, kas notiek Krievijas sociālajā, politiskajā un kultūras telpā gadsimtu mijā, un jaunais pasaules redzējums būtiski ietekmē žanru paradigmu. Jaunākās literatūras tendences ir apjoma minimizācija un žanru hibridizācija, kas nosaka arhaisko formu (viduslaiku paraugs, pasaka) reǵenerāciju.

\section{Narrative strategies in the latest Russian literature}

The article deals with issues of the genre system of the most recent Russian literature. The turn of the century radical changes in socio-political and cultural space and a new world view significantly impact the paradigm of genres. The research demonstrates that two existing tendencies in the latest literature - minimization of volume and hybridization of genres - cause regeneration of archaic forms: medieval patterns and the fairy tale, which indicates basic shifts in the genre system under the influence of the new world view. 
DOI: http://doi.org/10.22364/ruslat.glp.11

\section{Александр Житенев}

\section{Будущее литературы как объект моделирования (на материале публикаций журнала Pastor) ${ }^{1}$}

В статье анализируется специальный номер концептуалистского журнала «Пастор», посвященный будущему в условиях постмодерна, когАа все возможности развития культуры представмяются исчерпанными. На материале анкет писателей и художников концептуализма охарактеризованы оппозиции «общего» и

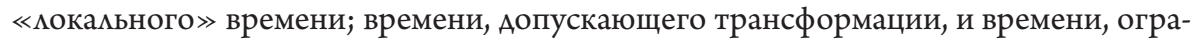
ничивающего их; времени как события и времени как пространства; времени, связанного с повторением и времени, предполагающего эффект непреАсказуемости.

Ключевые слова: будущее, моделирование, концептуализм, границы митературы, журнам «Пастор»

Будущее в истории митературы нового времени всегда было притягательным объектом моделирования, поскольку важнейшим мерилом ценности митературного текста была новизна, а будущее выступало средоточием нового, соотнесенность с которым обычно рассматривалась как среАство оценки митературной современности.

Отсылки к будущему как инструмент мегитимации митературной практики, определения перспективного и ценного Аавно находятся в поле митературоведческого интереса: «Попытки заглянуть в будущее, - отмечает А. Аихачев, - имеют значение не только Аля раскрытия будущего, но и Аля того, чтобы осознать настоящее - кроющиеся в нем возможности, отАелить творческие силы от нетворческих. Настоящее и современное - это не непоАвижность, а Авижение впереА» (Аихачев 1969: 168).

В художественной практике и эстетической теории ХХ века, особенно в эпоху исторического авангарда, значение будущего было фетишизировано. ПреАчувствие «нового мира» - при всем различии связанных с ним ожиАаний - обусловило расширенно-метафорическое истолкование будущего. Аля модернизма начала XX века «грядущее» - это «сфера эстетически невостребованных возможностей», противостоящая настоящему как

1 Исследование выполнено при финансовой подАержке РФФИ в рамках научного проекта № 18-012-00476 А «Эстетическая новизна и китературность как проблемы теории и творческой практики XX века: авангардизм 1920-1930-х гг. и постмодернизм 1970-1980-х гг.». 
«инобытие», сфера соединения реальности и идеала, переживания и выражения (Аазаренко 1993). Воплощаемое в слове, «грядущее» воспринималось как условие интенсификации его возможностей, полного раскрытия творящего субъекта.

Особенно остро потребность в апемяяции к авторитету будущего осознается в периоды, с которыми связано ощущение стагнации общественной и культурной жизни. В этом смысле типологически близкими эпохами, в равной мере зафиксировавшими отчуждение от субъекта его способности к целеполаганию и изменению мира, являются семидесятые и «нулевые».

О первом из этих периодов выразительно высказался В. Кривулин: «Мы - люАи, живущие в принципиально Аругом, внеисторическом измерении. Человек исторический полагает, что от его Аействия, от его Авижения зависит судьба какого-то исторического пассажа, что он может что-то решить в истории. Мы живем в совершенно Аругую эпоху <...> Тенденция такова, что время вообще как бы перестает течь» (Пути культуры 60-80-х гг. 1986: 232).

Очень близкой к этой формуле видится формула Р. Осминкина, констатировавшего радикальное сужение поля возможностей в 2000-2010-е гг.: «Аосрочность - вот общая черта нашего времени. <...> Самое страшное Амя нас - это совершить хоть какое-нибудь подобие субъективного выбора, последствия которого непреАсказуемы. < ... > Как бы рано мы не просыпаАись, мы всегАа просыпаемся слишком позАно. Все уже случилось досрочно. Мир сотворен не нами и без нас» (Осминкин 2014).

По контрасту с периодами иссякновения творческих возможностей, кажущейся утраты Аюбых временных координат в эпохи резкого слома ценностных систем проблема будущего приобретает иной виА. Будущее перестает осознаваться как пространство нереализованных возможностей и становится предметом напряженной рефмексии как область приложения созидательных сил, ответственность за которую цежит всецело на художнике.

Рубеж 1980-1990-х гг. - переломная эпоха с высокой степенью непреАсказуемости, в которую казались возможными мюбые системные савиги в кумьтуре. С ней бымо связано переживание «всевозможности» как универсальной характеристики ситуации перехода. Характерно в этом отношении суждение О. СеАаковой: «Аицо кажАого времени, внутреннее кицо <...> составцяет не столько его наличная Аанность, сколько заданность: горизонт, будущее, область его надежАы, цели, интенции»; историю митературы всегАа «можно написать как историю будущего» (Седакова 1990: 257).

Это будущее - именно потому, что оно утратимо преАсказуемость - стало мыслиться как некая совокупность возможных сценариев с разной вероятностью осуществления, реальность которых находится в зависимости от характера перестройки ценностных оппозиций. Выбор творческой стратегии писателя в этих условиях, как указывал А. Пригов, оказывается «Аелом исторической интуиции и риска»: автор утрачивает «авансированный 
гандикап Аоверия» и оказывается вынужден выстраивать себя, принимая в расчет изменчивость маркеров митературного поля и сужение масштабов художественного высказывания Ао масштабов митературного, а не культурно значимого факта (Пригов 1990: 212-216).

Ситуация перехода, предполагающая радикальную трансформацию базовых оснований митературного поля, обусловила интерес к осмыслению исторического времени как философской проблемы. Вариативность буАущего была увидена в контексте, когда изменчивыми оказываются сами рамки, в которых определяется значимость того или иного события. ОчевиАной преАПосылкой новой эпохи стала убежАенность в культурной обусловленности преАставлений о времени, об опосредованности мюбой временной схемы ценностным миром субъекта.

Комментируя публикацию работы В. Гигерича «Производство времени», А. Секацкий указывает как на характернейшую особенность фимософской мысли XX века на проблематизацию настоящего, которое вечно откладывается, никогАа не переживается как самоценная реальность: «Разработка интуиции времени только в нашем столетии стала философской задачей. Имя исходной операции Аах Жак Аеррида, это его знаменитое "difference", слово, имеющее Авоякое значение - “отсрочка" и “размичение”, Аифференциация. Аеррида и предположил, что источник разнообразия сущего (differences) - это эксперименты со временем, и в первую очереАь “откладывание на потом” » (Секацкий 1989).

Что значит «сейчас» в этой ситуации? В чем его ценность и чем она обеспечена? При каких условиях в этом «сейчас» возможно моделирование преАставлений о будущем? Эти и Аругие вопросы, связанные с осмысмением ситуации «постсовременности», оказались в фокусе тематического номера «Наше будущее» (1994) концептуалистского журнала Pastor Вадима Захарова. Предложенные в нем направления рассуждений преАставляются показательными и Аля рубежа 1980-1990-х гг., и Аля осмысления переходных эпох в целом.

Во-первых, значимой Аля журнала оказывается оппозиция «общего» и

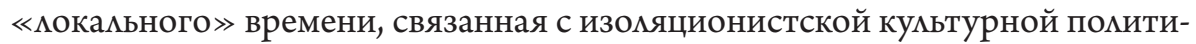
кой советского государства. Советская культура рассматривается зАесь как помещенная в своеобразную временную капсулу, внутри которой существуют свои собственные, не соотносимые с общей Амя всего остального мира, преАставления о культурной традиции и перспективах культурного и митературного развития. Выход из этого пространства в иные ценностные координаты созАает проблему «декомпрессии», вынужАенной аАаптации к новой реальности.

Об этом как значимой координате, опредемяющей современное сознание, ретроспективно пишет И. Шелковский: «Мы жили в Аругом времени, блаженно отделенные от проблем мирового современного искусства прочным железным занавесом. <...> Подобно глубоководным распиющенным рыбам мы ползали по темному илистому Ану поА Аавлением во множество 
атмосфер, и мишь после смерти Сталина начался подъем к поверхности, к мутному свету и бликам современности со множеством остановок Аля Аекомпрессии на каждом этапе» (Шелковский 2009: 235-236).

В ситуации многоэтапной переоценки собственных Аостижений во все расширяющемся контексте преАставцений о границах актуальности возникает парадоксальное «монадологическое» и «ретроспективистское» прочтение будущего. Его суть заключается в том, что будущее осознается как замкнутое на уникацьный опыт субъекта и при этом выстраивается «назаА», через апологию прошиого, поиск путей интеграции этого «вторичного» или исторически мокацьного опыта в универсальную систему смысмов и ценностей.

Характерно, что вопрос о будущем Юрием Альбертом переформулируется в вопрос о будущем прошиого, поскольку преАставление об искусстве всегда может быть пересмотрено, и все опыты, сделанные в завершившейся эстетической парадигме, оказываются архаичными, утрачивают право на продолжение. Противопоставляя «будущее искусства» (ситуацию, когАа мы знаем, что такое искусство) и «искусство будущего» (о котором ничего не известно), художник отмечает, что переА полной неизвестностью опорой оказывается только собственное прошлое: «Хотя будущее Аовольно закономерно вытекает из прошлого, закономерность эту обычно можно разглядеть, только огляАываясь назаА. <...> Аучше иАти спиной впереА и не выпускать из виду хотя бы прошиого, чтобы совсем не заблудиться» (Альберт 2009: 232; ср.: Кабаков 2009).

Такая постановка вопроса позволяет отметить связь межАу высокой ценностью будущего в автоописательном тексте и потребностью субъекта в будущем как открытом наборе возможностей. Так в «Пасторе» возникает еще оАна оппозиция, значимая Аля интерпретации проблемы будущего: время, Аопускающее трансформации - время, ограничивающее или искиючающее трансформации.

В «пасторском разговоре» философа Б. Гройса и писателя П. Пепперштейна в разговор о будущем естественным образом вплетается тема возраста, в которой острая потребности в будущем и восприимчивость к новому оказываются производными от молодости и творческой активности субъекта: «У меня есть ощущение, что ничего нового не происходит. Это эффект старости. < .. > Человек имеет историю, потому что он трансформируется, но его трансформация ограничена. Причем мы не знаем, почему мы перестаем трансформироваться: то ми мы застыли в определенной форме, тол и слишком сильно порвали с преАыдущим субъектом, и это уже стал не тот, а Аругой субъект» (Гройс, Пепперштейн 2009: 215).

Этот мотив «старости» проецируется П. Пепперштейном на советский проект, повсеАневность которого в 1960-1970-е гг. осознается как «осуществившееся будущее»: «Собственно, это и бымо будущее, фантазируемое на протяжении преАшествующих ста мет, - оно тогАа не просто осуществи-

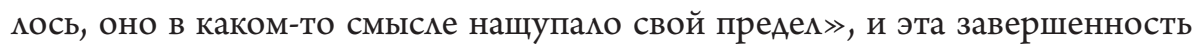




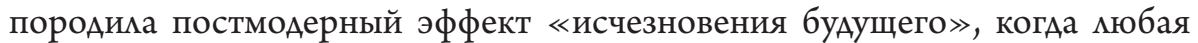
«беспрецедентность замаскирована под сплошное “уже виденное”, “уже бывшее” » (Гройс, Пепперштейн 2009: 214).

Такое прочтение «исторического» сквозь призму субъектности позволяет выченить в материалах журнала еще одно значимое противопоставление: оппозицию субъектно освоенного - субъектно не освоенного времени или, что равноценно, оппозицию времени как Авижения и времени как набора пространственно организованных фрагментов опыта. Эти противопоставления также появляются в беседе Б. Гройса и П. Пепперштейна.

В понимании Гройса «будущее Аля искусства» и «будущее Аля мира» имеют разный смысл, поскольку «искусство не развивается в Аинеарном времени», а преАставцяет собой некую форму «пространственной памяти», в которой все элементы могут приобретать качество актуальности. Осознание этого и обусловило тот факт, что в постсовременной культуре «Аискурс будущего» прекратился, и культура перешла «в сферу вечного настоящего» (Гройс, Пепперштейн 2009: 213).

ОАнако Аля субъекта «вечное настоящее» различных объективаций означает разрушение идентичности: «Я ... очень остро чувствую разрывы в своей субъективности <...> и постоянно играю разные роли, которые нельзя соединить межАу собой и которые не образуют никакой последовательности прошиого, настоящего и буАущего, а преАставляют собой разрозненные эпизоды. Это все настолько расчленено, что из времени превращается уже в пространство» (Гройс, Пепперштейн 2009: 216).

Пространственная непрерывность культуры никак не пересекается с пространственной разорванностью иичного опыта, но эта несведенность имеет смысл постоянного раздражителя, снова и снова побужАающего производить знаки. Разговор о будущем в этом смысле - это разговор о таких разрывах. «В самой идее буАущего, - говорит Пепперштейн, - присутствует, с оАной стороны, обостренное неАоумение. И, с Аругой стороны, постоянная угроза Амя этого неАоумения. И осуществмение будущего, его реализация связаны с потребностью спасти недоумение, воссозАать Аисбаманс, эффект разрыва» (Гройс, Пепперштейн 2009: 220).

Та же идея разрыва акцентируется и Б. Гройсом, Аля которого интелмектуальная непроницаемость нового в искусстве обоснована попыткой созАать иную чувственность: «Мне кажется, что будущее искусства заключено в генетических манипуляциях с человеческим телом и с его органами восприятия, т.е. в производстве монстров: смена объектов эстетического восприятия неАостаточна - и Аолжна быть расширена на сами по себе механизмы восприятия. < .. > В кумьтуре будущего я не смогу слелать ничего, поскольку не смогу изменить своего тела - а, следовательно, и своей Ауши» (Пасторская анкета 2009: 246).

Инакомерность будущего Аругими участниками тематического номера воспринимается не только как источник травматических разрывов в субъекте, но и как интемлектуальный вызов, вынуждающий отказаться от 
шаблонных представлений об эволюции культуры, переформулировать сами основания рассуждений на эту тему. В этом отношении показательна могика короткой заметки М. Рыклина. Философ противопоставляет «кумулятивное будущее», в основе которого идея минейного развития, и непреАсказуемое разнонаправленное развитие с будущим как «авантюрой»: «В основе преАсказуемого, контролируемого будущего межит трансценАентальная субъективность, могика представления»; но Ааже «кумулятивное будущее $<\ldots>$ зАесь и теперь наиболее ускользающе и многозначно: их, будущих, намечается множество, среди них пока нет фаворита, мелкие ставки приходится Аекать практически на все возможные варианты» (Рыкиин 2009: 229).

Непродуктивность идеи прогнозируемого будущего, которое, «как табурет, можно было бы взять и унести», развивает в «пасторской» анкете и Н. Алексеев: «Сомневаясь в минейности (хотя бы круговой) времени и одновременно веруя в некую цель, я стремлюсь не одевать время в наряды, которые я способен преАставить» (Пасторская анкета 2009: 240-241).

Таким образом, резюмируя разные направления рассуждений, можно в качестве важнейших принципов осмысления будущего в ситуации культурного разрыва отметить илеи «сконструированности» будущего, его опосреАования разАичными проявлениями субъективности, зависимости преАставлений о будущем от концепций развития, понимания набора факторов необратимых изменений.

\section{Литература}

Альберт, Ю. (2009). Есть ми будущее у нашего прошиого? В: Pastor. Сборник избранных материалов, опубликованных в журнале «Пастор». 1992-2001. Вологаа: Pastor Zond Edition. C. 232-233.

Гройс, Б., Пепперштейн, П. (2009). Наше будущее В: Pastor. Сборник избранных материалов, опубликованных в журнале «Пастор». 1992-2001. Вологаа: Pastor Zond Edition. C. 213-228.

Кабаков, И. (2009). В будущее возьмут не всех. В: Pastor. Сборник избранныхх материалов, опубликованных в журнале «Пастор». 1992-2001. Вологаа: Pastor Zond Edition, 2009. C. 237-238.

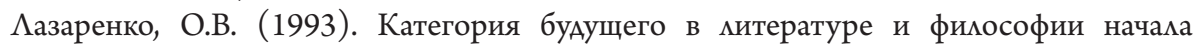
ХХ века. В: Время Алгилева. Универсалии серебряного века. Пермь: Перм. гос. ун-т, 1993. C. $78-88$.

Аихачев, А.С. (1969). Будущее китературы как предмет изучения (Заметки и размышиения). Вопросы митературы. № 9. С. 167-184.

Осминкин, Р. (2014). Эссе о будущем. Аоступен на 16.02.2018: http://anticapitalist.ru/ archive/kultura/roman_osminkin._esse_o_budushhem.html

Пасторская анкета (2009). В: Pastor. Сборник избранных материалов, опубликованных в журнале «Пастор». 1992-2001. Вологаа: Pastor Zond Edition. C. 240-251.

Пути культуры 60-80-х гг. (1986). Часы. № 62. С. 218-233. Аоступен на 16.02.2018: http://samizdat.wiki/images/6/69/62_-_15_-_\%D0\%9F\%D1\%83\%D1\%82\%D0\% B8_\%D0\%BA\%D1\%83\%D0\%BB\%D1\%8C\%D1\%82\%D1\%83\%D1\%80\%D1\%8B.pdf 
Пригов, А.А. (1990). ГАе наши руки, в которых находится наше будущее? Вестник новой иитературы. № 2. С. 212-217.

Рыклин, М. (2009). [Наше будущее] B: Pastor. Сборник избранных материалов, опубликованных в журнале «Пастор». 1992-2001. Вологаа: Pastor Zond Edition. C. 229-231.

Седакова, О. (1990). Музыка глухого времени (русская мирика 1970-х гг.) Вестник новой митературы. № 2. С. 257-265.

Секацкий, А. (1989). Мовушки Аля времени Митин журнал. № 25. Аоступен на 16.02.2018: http://kolonna.mitin.com/archive.php?address=http://kolonna.mitin. com/archive/mj25/chorba.shtml

Шелковский, И. (2009). Перепады времени В: Pastor. Сборник избранных материалов, опубликованных в журнале «Пастор». 1992-2001. Вологаа: Pastor Zond Edition. C. 234-236.

\section{Literatūras nākotne kā modelēšanas objekts: žurnāla "Pastor" publikācijas}

Rakstā analizēts konceptuālā žurnāla "Pastor” speciālais numurs, kas veltīts literatūras nākotnei postmodernisma apstākḷlos, kad visas kultūras attīstības iespējas šķiet izsmeltas. Pamatojoties uz konceptuālisma rakstnieku un mākslinieku anketēšanas materiālu, raksturota vispārējā un lokālā laika opozīcija; laiks, kad transformācijas tiek piel̦autas, un laiks, kad transformācijas tiek ierobežotas; laiks kā notikums un laiks kā telpa; laiks, kas saistīts ar atkārtošanos/cikliskumu, un laiks, kas pieḷauj neprognozējamus procesus.

\section{Future of literature as the object of modelling (based on publications of the "Pastor" magazine)}

The article analyses different versions of the future of literature, thus the modern Russian situation with the preserved present and the "absent" future appears as the reference point. The object of the research is the special issue of the conceptualist magazine "Pastor" devoted to the future in postmodern conditions when all the possibilities of cultural development are represented as exhausted. The opposition of the "general" and "local" time is characterized on the basis of the material of the survey of conceptualism writers and artists; time allowing transformations and time limiting them; time as an event and time as space; time connected with repetition and time assuming effect of unpredictability. The meanings of these oppositions are revealed and the principles of creation of the models of the future are analysed. 
DOI: http://doi.org/10.22364/ruslat.glp.12

\section{Анна Фролова}

\section{Эстетика аутсайдерства в современной детской литературе ${ }^{1}$}

Вся современная русская митература испытывает интерес к исследованию маргинального. Ситуация отверженности может порождаться разными причинами: телесным состоянием, социальным статусом, национальной идентичностью и пр. Внимание к этой проблеме объясняется высокой степенью конфмиктности современного российского общества, отсутствием единого ценностного поля. Аетская митература тоже откиикается на эту ситуацию, исследуя фигуру отверженного ребенка. Авторская стратегия очевидна: необходимо преодолеть стереотип восприятия аутсайдера, естественно социализовать его.

Ключевые слова: Аетская митература, аутсайдерство, школьная повесть, герой-подросток

Аетская митература сегодня, по замечанию Н. Барковской, «не обочина митературного помя, а самый его центр, гАе разыгрываются самые острые конфликты и ведутся наиболее интенсивные поиски их разрешения» (Барковская 2014: 140). Возрастающее внимание к этому пласту митературы объясняют сложностью Аиалога отцов и Аетей, связанной с отличием жизненного и культурного опыта, обострением проблем семьи, тревогой роАителей за нечитающее поколение и пр. Аетская митература, естественно погружая юного читатемя в круг близких ему интересов и впечатлений, призвана «доставлять ребенку эстетическое наслаждение и способствовать формированию его мичности» (Арзамасцева 1997: 7).

ОАним из самых ожидаемых объектов исслеАования становится современная школа - больной вопрос Аля всего общества, центр притяжения сил и эмоций. Стало привычным обращаться к школьной теме через призму иичного опыта, что позволяет провести «своеобразное сканирование этапов взросления целого поколения (Черняк 2010: 14). Современная школьная повесть стала «жестче, предельно реалистичнее, ее основная цель - изображение реацьного мира и его проблем, а не идеализация окружающего, в

1 Исследование выполнено при финансовой подАержке РФФИ в рамках научного проекта № 18-012-00476 А «Эстетическая новизна и митературность как проблемы теории и творческой практики XX века: авангардизм 1920-1930-х гг. и постмодернизм 1970-1980-х гг.». 
ней нет установки на создание образца Аля подражания, идеацьного героя, наоборот, герой Аолжен быть предельно жизнеподобен, узнаваем» (Кутейникова 2017: 92).

Обратимся к нескольким произведениям детской митературы послеАних мет. Название книги Тани Беринг и Аюбови Романовой «Аетки» (2014) неоднозначное, оно может быть прочитано и с умилительно-снисходительной интонацией, и с осужАающе-горькой. Аизайн обложки, выполненный в стиле книг Стивена Кинга, побужАает склониться ко второму варианту: испуганный махьчик, прячущийся в траве от преследующих его фигур в сером. Последние имлюзии развеивает аннотация: «Тот, кто называет школьные годы самым безоблачным временем в своей жизни, мибо врет, мибо страдает расстройством памяти. Авторы этой книги не собираются вводить вас в заблуждение. “Аетки” - это три остросюжетные истории, которые сложно назвать безоблачными. КажАая из них основана на реальных событиях из жизни подростков» (Беринг, Романова 2014).

В рассказе «Мой масковый и нежный тромль» экспиуатируется традиционный Аля школьной повести хоА - перевоА героя в новую школу и необхоАимость пройти социальную аАаптацию, сделать незнакомое и чужое пространство обжитым и своим. В произвеАении Тани Беринг в Аевятый класс престижной гимназии приходят Ава новых ученика. ПреАставляя их классу, учитель сразу расставляет показательные акценты: «Варвара училась в оАной из школ спального района, по-моему, в Щербинке, а Аарон приехал из Англии» (Беринг, Романова 2014: 31). Если вспомнить советскую школьную повесть, то в ней учитель тоже говорил о том, из какой школы прибыли новые ученики, однако в рассказе Беринг эта информация приобретает статус характеристики. Социальный акцент оказывается опреАеляющим и в отношении класса к героям, и в их самоощущении.

Варвара - талантливая, целеустремленная натура, сама слала сложное тестирование в престижную школу, чтобы иметь хоть какую-то перспективу поступления в медицинский вуз. Она мечтает стать врачом по мичным причинам: неизмечимая болезнь младшего брата перевернула жизнь семьи (уходит, не выдержав, отец, мать из-за нервного истощения попадает в больницу, в семье скромный материальный достаток). Варвара относится к числу тех учеников, кто «Аелает школе рейтинг», оАнако это не приносит ей уважения оАноклассников. ГАавным Аля них становится «раритетная модель» телефона, вязаный свитер, немодные туфли, Варя в их глазах «нищебродка». Героиня Аержит уАар, однако мучается невысказанными сомнениями и вопросами, понятными мюбому подростку: почему ее семья живет так скромно, как иАти на свиАание с самым моАным мальчиком школы, если у тебя нет «брендовых» вещей, как позвать его в гости в махенькую квартирку и пр. Автор не идеализирует героиню, а показывает сложность ее выбора. Варя устраивается на работу в МакАональдс, чтобы отдать Аеньги за рок-концерт, и в то же время мжет одноклассникам, матери, была близка к краже Аорогой одежАы. 
Как и во многих произведениях современной Аетской митературы, в рассказе Т. Беринг проблемы героев-подростков взрослыми мибо игнорируются, мибо обесцениваются, а зачастую усугубцяются. Социальное неравенство в престижной гимназии учителями воспринимается как Аолжное. Так, классная руководительница в стремлении быть «суперсовременной учительницей» организует поход класса на рок-концерт. Она Ааже не сомневается, что родители, «в конце концов, найдут <..> Аве тысячи» (Беринг, Романова 2014: 36). Аиректор школы больше всего озабочен рейтингом школы, а не атмосферой в ней и взаимоотношениями учеников. Конфликт межАу Варей и Аароном решается в пользу послеАнего, веАь тот оказался в этой гимназии «просто потому, что так решиц его папа» (Беринг, Романова 2014: 32). Оказывается, что Аоказывать право на пребывание в престижной школе нужно побеАительнице олимпиаА «Варваре Снежиной из Спацьного Района», а не сыну политика.

В отличие от семьи Вари, в семье Аарона «все как положено»: мать «красивая, стильная» «блондинка без возраста», состоятельный отец. У них «обоюдный» грех: Аарон - сын мюбовника матери (состояться их браку помешала его бедность), у отца есть внебрачная Аочь. Все возникающие проблемы решаются оперативно с помощью Аенег. Семейная беспринципность своеобразно преломляется в Аароне: уверенный в том, что «выживает сильнейший», он становится «тромлем». Тромлинг - форма социальной провокации или издевательства в сетевом общении, использующаяся как персонифицированными участниками, заинтересованными в большей узнаваемости, публичности, эпатаже, так и анонимными пользователями без возможности их илентификации. Ради развлечения Аарон провоцирует ряА сканАалов, привеАших к отчислению Авух учеников из школы, падению рейтинга гимназии. Варя сама становится жертвой насилия, ее вынуждают уйти из школы, она останавливается в шаге от края крыши. В финале рассказа героиня объединяется с еще одной жертвой Аарона, и девочки сами становятся «тромлями», а Аарон - их жертвой. Но изменение роли небезобидно, в первую очереАь, Аля бывшей жертвы. Варя сильно изменилась: Аоверие к миру, вера в справеАливость подорвана, возвращение к себе прежней невозможно.

Еще большими потерями сопровожАается переход во взрослую жизнь героев рассказа $\Lambda$. Романовой «Мы приговариваем тебя к смерти». Если в предыАущем рассказе сюжет определялся историей аАаптации новичков к реалиям новой школы, то в произвеАении $\Lambda$. Романовой читатель поАКлючается к Аавно сложившимся отношениям Аесятиклассников. Сюжет Аинамичен, повествование ведется от мица Авух героев-одноклассников - Миши Нефедова и Саньки Морозова. Родившиеся в один Аень, они ни в чем не похожи: Нефедов рыхлый, флегматичный, интровертный, Аекламирующий «про себя» стихи Есенина, тонко чувствующий природу, а Морозов «высокий, красивый», «играет на гитаре и поет про вечную мюбовь», спортивный. Роли Аавно распределены: изгой по кличке Нюфа и милер Мороз. 
Исследуя характер аутсайдерства, Романова акцентирует внимание на его иррациональной природе. Так, Нефедова все считают «ботаном», но он «учится так себе», а Морозов - признанный мидер, казалось бы, у него нет необходимости доказывать свое первенство унижением другого. Травля настолько продолжительна, что ее участники освоили свои роли: Нюфа уже знает, что «в такие моменты не нужно ничего доказывать», нужно «молчать и жАать, когАа им надоест» (Беринг, Романова 2014: 16), а Мороз придумывает все более изощренные способы унизить своего врага. Благодатной почвой Аля травли становится полное равнодушие взрослых (их отсутствие в рассказе показательно), пассивное поведение класса, чье неучастие дает поддержку Морозу и компании.

Неуправляемый характер травли предопределил непредсказуемое развитие сюжета. Рассказ начинается интригующе: «Я не пошел на его похороны. Нужно было готовиться к мабораторной по химии. Событие не бог весть какой важности. Но заваливать не хотелось. К чему? Ему все равно, а мне еще поступать ... » (Беринг, Романова 2014: 9). Аалее события развиваются так, что читателю не приходит в голову усомниться в кандиАатуре самоубийцы. Нефедов привык к разным «шуткам», жестоким, но Ао опреАеленного момента шкомярским (закрыли в шкафу переА уроком, испачкали стул подсолнечным маслом). Все меняется, когАа «стая» решает организовать показательную «казнь», обвинив Мишу в воровстве, которое сама же организовала. То, что сначала Нефедов определяет как «театр абсурда», скоро выходит из-поА контромя организаторов и оборачивается трагедией. Морозов «не то чтобы собирался прикончить Нюфу, просто привык всегАа Аобиваться результата», его змит, что тот молчит, а не «воет, умоляя отпустить его к мамочке» (Беринг, Романова 2014: 20). Саня смотрит на Нефедова как на «жертву розыгрыша», не понимая, что переступил грань, прошеА «точку невозврата», приговорив человека к повешению, которое тот воспринял как реальное.

Казнь стала поворотным моментом и в сюжете, и в самоощущении героев. Пережив почти реальную смерть, Нефедов утратия способность бояться, «стал своим» в «стае». Морозов же не только потерял авторитет среди оАнокАассников, но и осознал Аушевную пустоту, никчемность собственной жизни. Бывшая ровной Аорога жизни оборачивается бездорожьем (герой Аолго плутает по месу), его накрывает незнакомое доселе чувство страха. Веревка, которую ребята в шутку набросили на шею Нюфе, метафорически оказывается на шее Морозова: «Накатившая тоска свернулась тугим кольцом и саавила шею» (Беринг, Романова 2014: 26). Тот с ужасом сознает, что «смерть, в сущности, не самая страшная штука» (Беринг, Романова 2014: 26). Интрига, заданная в первом абзаце рассказа, разрешается в послеАней главке: Саня Морозов покончил жизнь самоубийством, а Миша Нефедов не хочет иАти на его похороны.

Ситуация перевернулась: мидер и аутсайдер поменялись местами, однако Аля автора рассказа это ничего не решает. Аело не в том, кто изгой, а в том, 
что он есть. Кроме того, Аля Нефедова не случается счастливого освобожАения. Он кардинально изменился: стал жестче, циничнее, он даже бцагодарен Морозову за «полезную ампутацию» («Он убим во мне Нюфу» (Беринг, Романова 2014: 27)). Вместе с тем очевидно, что «вместе с размазней Нюфой» герой мишился «чего-то очень важного», Ао конца еще не осмысменного. Он, например, не верит в то, что Морозов покончил с собой из-за чувства вины, опыт бывшего изгоя подсказывает герою только одну версию: «Саня, привыкший к всеобщему обожанию, так и не смог смириться с паАением своей попумярности» (Беринг, Романова 2014: 27). Нефедов обживает новую Аля себя роль мидера, наслажАается ею и не допускает мысли, что в позиции сильного можно испытывать к себе «острое отвращение».

О смерти подростка идет речь и в повести Светланы Волковой «ПоАсказок больше нет» (2015), вышеАшей в серии «СреАняя школа №.... ». Ситуацию изгойства переживает старший брат главного героя Антон. Он вспоминает свои «вечные муки самоутверждения в чужом комлективе», когАа его травили как новичка, к тому же самого младшего в отряде, трудолюбивого и спортивно одаренного. КогАа в магере появляется Аругой новичок, Антон помогает ему. ИльАар Хафизов плохо говорит по-русски и становится объектом насмешек. Изгойство с национальным оттенком - сложный Аля детской митературы материал, но, бесспорно, актуальный. Ильдар Хафизов, оказавшись в чужой «стае», выбирает путь преАательства, мотивы которого очевидны - желание быть «как все», выжить. Антон же получает урок на всю жизнь: «<...> один изгой с животным наслаждением находит еще большего изгоя, наА которым так сладко поглумиться, высвобожАая собственную подменькую забитую душонку» (Волкова 2015: 218). Ситуация изгойства становится переходным моментом Аля героя, поведение в ней предопредемяет его Аальнейшую жизнь. Антон понимает, «что Аетство кончилось», а во взрослой жизни «поАсказок больше нет».

Современная детская митература обратилась также к очень болезненному материалу - положению детей, выброшенных из нормальной жизни в силу особенностей своего развития. Среди произведений, разрабатывающих этот аспект, можно назвать повести Екатерины Мурашовой «КАасс коррекции» (2007), Ксении Беленковой «Я учусь в 4 КРО» (2016), Алисы Рекуновой «Жизнь среди мюАей» (2015), роман Мариам Петросян «Аом, в котором... » (2009). Писатели ставят вопрос категорично: есть Аи место «среди Аюдей» Аетям с проблемами развития?

Повесть Ксении Беленковой автобиографична, автор по профессии коррекционный педагог. В послесловии к произведению К. Беленкова пишет о том, что «все описанные герои - настоящие» (Беленкова 2016). Время Аействия - один учебный гоА жизни коррекционно-развивающего класса. В повести девять глав, кажАая написана от Аица конкретного ученика. Необходимо отметить, что дети, попавшие в 4 КРО, не нормальные, попавшие в трудную жизненную ситуацию, а Аействительно с серьезными проблемами, выливающимися в странное поведение на уроке: один все время спит, 
Аругой воображает себя собакой, третья хохочет, четвертый может заорать среАи урока и дерется с кулером. Автор предлагает читателю посмотреть на мир глазами своих героев, пытающихся объяснять его в меру своего разумения. Вместе с тем мир повести светлый: автор акцентирует внимание не столько не дефектах героев, сколько на их неиспорченных душах. Они не осваивают элементарных знаний, зато обладают даром сопереживания, богатой фантазией, Ааром предчувствия, тяжело переживают трагеАию, случившуюся с Катей Романенко. В 4 КРО нет аутсайдера, это особый мир, но нельзя не отметить, что класс в школе на особом положении. Аетей воспринимают как «ошибку природы». Семейные истории ребят тоже безрадостны. У Марты маму мишили родитемьских прав из-за пристрастия к алкоголю. У Аимы развелись родители, и кажАый занят своей мичной жизнью. Папа Вовы так занят работой, что ни разу не поинтересовался у сына, выполним ми тот домашнее задание, а мама Миши «помешана» на вегетарианстве, отчего ее ребенок ходит вечно голодным и отбирает бутерброды у Аругих. Становится понятно, что благополучие этих Аетей в руках взрослых. По окончании гоАа класс расформируют, и нетруАно АогаАаться, что жАет таких Аетей в окружении их «нормальных» сверстников. ОАин из учеников мечтает о Законе Благородства: «И только сейчас сообразил, что Аальше будет только хуже. Это какой-то закон подиости: все плохое когАа-нибудь заканчивается, и начинается ужасное. Аавно пора изобрести закон Благородства! Он будет гласить - все хорошее когда-нибудь заканчивается, и начинается прекрасное» (Беленкова 2016).

Герой повести Алисы Рекуновой «Жизнь среди мюдей» страдает бомезнью Аспергера, причем Аолго об этом не подозревает. Ао момента, как мы узнаем о Аиагнозе героя, он воспринимается как странный подросток, опережающий в развитии одноклассников. Он не хочет повторения отношений в прежней школе, гАе его считали «ботаном», и стремится во что бы то ни стало установить контакт с оАноклассниками: «Я просто хочу быть как все. Хочу общаться с мюАьми, Аружить, смеяться наА чьими-то шутками, говорить впопаА. Хочу быть частью чего-то. Чего-то большего, чем я сам» (Рекунова 2015: 52). Естественная потребность в общении, Аружбе, мюбви заставцяет Алексея закрывать глаза на явно недружеское поведение новых оАнокиассников, пользующихся возможностью провоАить время в его квартире. ОАнако, как бы герой ни старался «жить среАи АюАей», он слишком отличается от Аругих, чтобы не стать изгоем. Ситуация осложняется семейным аутсайдерством. Мать слышать не хочет о Аиагнозе сына, отец не оказывает подАержки, бабушка называет внука «недоделанным», отчим считает избалованным и бьет.

Повесть демонстрирует особенности мировосприятия, мышиения аутиста, однако не это оказывается главным. Отстраненность героя позволяет автору показать, как мюАи строят отношения Аруг с Аругом, увидеть неприглядную Аействительность, воспринимаемую как норму. Оказывается, что Аюбому герою-подростку есть что скрывать: семейное неблагополучие, 
неуспеваемость по школьным предметам, слабоволие и пр. Становится понятным, что кажАЫй прохоАИт Путь обретения своей иАентичности в оАИночку, методом «проб и ошибок», но все стремятся к оАному - «жить среАи АюАей» и вместе с ними.

Острота постановки вопросов об утрате способности к пониманию и состраданию во взрослом мире и реАукции человеческого - то, что отличает современную детскую прозу. Критики, анацизирующие ее состояние, констатируют, что сегодняшняя школа «оказалась пострашнее школы тотамитарной и советской» (Черняк 2010: 17). Современная проза обнажила «социальную безАну, в которую заглядывают уже и без всякого ужаса, просто по привычке к тому, что ничего нельзя изменить» (АебеАушкина 2009). Жесткая митература о шкоме и Аетях - попытка объективного и трезвого анализа мира и общества, которые ничего не могут преАложить человеку - ни общественных, ни общечеловеческих ценностей. Отсюда невозможность решения проблемы: писатели, привлекая внимание к ситуации аутсайдерства, не предлагают никаких социальных механизмов ее преодомения.

\section{Литература}

Арзамасцева, И.Н. (1997). Аетская литература: учебное пособие для студентов средних педагогических учебных заведений / И.Н. Арзамасцева, С.А. Николаева. Москва: ИзАательский центр «Академия». 448 с.

Барковская, Н.В. (2014). Проблема Аискурсивного конфмикта в современной детской митературе. Педагогическое образование в России. № 5. С. 140-144.

Беменкова, К. (2016). Я учусь в 4 КРО. Аоступен на 26.02.2018: http:// kniguru.info/ ya-uchus-v-chetvyortom-kro

Беринг, Т., Романова, $\Lambda$. (2014). Аетки. Москва: БерИнга. 120 с.

Волкова, С. (2015). Подсказок больше нет. Москва: ИзАательство АСТ. 318 с.

Кутейникова, Н.Е. (2017). Навигатор по современной отечественной детскоподростковой и юноческой митературе: методические рекомендации. М.: МАЭСТРО ПиаТинум. 158 с.

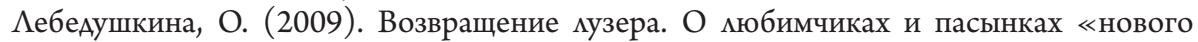
производственного романа»-2. Аружба Народов. № 11. Аоступен на 26.02.2018: http://magazines.russ.ru/2009/11/le18-pr.html

Рекунова, А. (2015). Жизнь среди мюдей. Москва: ИзАательство АСТ. 442 с.

Черняк, М.А. (2010). Школа как Аиагноз: опыт современной прозы. В: Аетскал митература сегодня: сб. науч. ст. Екатеринбург: УрГПУ. С. 7-17.

\section{Autsaiderisma estētika mūsdienu bērnu literatūrā}

Mūsdienu krievu bērnu literatūrā ir vērojama interese par marginālām parādībām. Autsaiderismu var radīt dažādas situācijas: ķermen̦a stāvoklis, sociālais statuss, nacionālā identitāte u. c. Mūsdienu krievu sabiedrībā ir augsts konfliktu līmenis un nav vienota vērtību lauka. Bērnu literatūra, reageèjot uz šādu situāciju, uzmanības centrā izvirza atraidītā bērna tēlu. Autoru stratēgija: jāpārvar autsaidera uztveres stereotips, to dabīgi socializējot. 


\section{Outsider aesthetics in modern children's literature}

All modern Russian children's literature is interested in studying the marginal. The situation of rejection can be caused by different reasons: physical condition, social status, national identity, etc. The interest in this problem is stirred by a high degree of conflict in modern Russian society and the absence of a single homogeneous value field. Children's literature also responds to this situation by examining the figure of an outcast child. The author's strategy is obvious: it is necessary to debunk the outsider stereotype by naturalizing it. 
DOI: http://doi.org/10.22364/ruslat.glp.13

\section{Ирина Антанасиевич}

\section{Поп-культура и знаки войны}

В статье рассматривается проблема военного шеврона как маркера в опознавательной системе «свой - чужой». Шеврон имеет Авойственную природу, будучи обращен одновременно к категории «своих» и «чужих». Материалом Аля статьи послужили военные шевроны, бытовавшие в период югославских войн в конце 1990-х гг. на территории Балкан и использовавшиеся сербской и хорватской сторонами. Югославские шевроны этого периода активно заимствуют образы и персонажей из массовой (американской в первую очередь) культуры.

КАючевые слова: знаки войны, поп-культура, Югославия, шеврон

Коммуникативная система войны преАставмяет собой особую систему, внутри которой нарушаются привычные в мирное время коммуникативные табу и прескрипции. Взамен формируется система, которая запускает новые смыслы и новые символы - неактивные или слабо активные в мирное время. Шевроны ${ }^{1}$, явмяясь простейшими маркерами в опознаватемьной системе «свой - чужой», преАставляют собой базовую часть такой коммуникативной системы. Военный шеврон по сути дела преАставляет собой простейшую коммуникативную форму, в которую упаковывается «своя» информация: в таком виде она хорошо отличима от «чужого» текста. Аля созАания «своей» информации могут быть использованы знаки, с оАной стороны, универсальной природы, то есть общие и понятные Аля всех воюющих сторон. С Аругой стороны, зАесь могут активизироваться архаичные символы - как общей природы, так и местного, Аокального происхождения. И наконец может перениматься и чужая символика, которая, после перекоАирования, включается в смысловое поле знака уже как «своя».

Помимо прочего, шеврон - это и информация, предназначенная Аля «чужих». И в этом качестве он Ааже важнее, чем маркер, по которому опреАеляют «своих». Иными словами, шеврон необходим Аля базовой коммуникации войны как знак, который «мыслится возАвигнутым в гуще боя, на глазах у Арузей и врагов, Аля воодушевления первых и Амя “ожесточения”

1 Шеврон - в Аанной статье под шевроном понимается знак-нашивка, изображение, помещенное на одежде (на рукаве, груди т.А.) в качестве различительного знака разных военных групп. Обычно шевроном принято именовать графический знак, состоящий из Авух отрезков, соединенных концами поА углом, наподобие матинской буквы V. 
вторых» (Кайуа 2003: 76). С учетом Авойственной природы заключенного в нем сообщения, исследование символов, используемых шевроном, усложняется, поскольку в простой механизм «опознания» вкладывается текст, который требует более развернутого (про)чтения.

Кроме того, такой символ-знак во время войны обладает обязательно еще и социальной дополнительной функцией оберега - как комеективного, так и мичного, поскольку комлективные функции обязательно трансформируются в Аично-индивидуальные: АюАи начинают верить в исключительность знака-символа, считая его своим мичным покровителем. По этой причине шеврон не просто маркер, обозначающий группу «своих», не просто сообщение, предназначенное Аля чужих, не просто знак, который использует общий универсальный коА, перерабатывая его Аля своих нужА (конкретизируя, привязывая к национальным особенностям), но еще и оберег, что усложняет текст, заключенный в знаке.

Если мы при чтении подобного знака будем учитывать все указанные выше составляющие, то толкование военных шевронов Ааст нам возможность, во-первых, больше узнать о самом знаке войны, во-вторых, более Аетально рассмотреть процесс формирования подобных знаков и их семиотическую природу, и, в-третьих, иссмедовать текст сообщения, основной темой которого явцяется тема смерти.

На шевронах югославских войн конца 1990-х годов ${ }^{2}$ самым частым изображением явмяется изображение черепа или «мертвой головы». Употребление этого символа, разумеется, вкцючало в себя всю палитру значений, которые содержит в себе этот символ в мировой культуре, но при анализе сербско-хорватских столкновений - это прежде всего идея противостояния «четников ${ }^{3} \gg$ и « «сташей ${ }^{4} \gg$.

Изображение черепа и костей (см. рис. 1$)^{5}$, явмяясь символом сербского четнического Авижения, подчеркивало связь с его ияеологией. $\mathrm{O}_{\mathrm{A}}$ новременно оно сообщало противнику, что в основе столкновений межит исторический конфмикт межАу сербами, которые воспринимали себя как четники, и усташами - непримиримыми религиозными и идеологическими врагами сербов. При этом у усташей изображение черепа встречается реже.

2 Под этим термином мы понимаем серию вооруженных конфликтов на территории бывшей Югославии, привеАших к ее распаАу.

3 От сербского слова чета - взвод. Монархическое сербское националистическое Авижение, окончательно сформировавшееся в начаме XX века, хотя первые четы появились намного раньше как группы бунтарей, борющихся за освобождение от вмасти турок.

4 От сербского слова устати - встать. Националистическое Авижение, сформировалось из группировок, составцявших в 1920-х ультранационалистическое крыло хорватской оппозиции против централизованного общественного устройства королевства Югославии.

5 Всегда сопровожАалось мозунгом: «С верой в Бога! Свобода или смерть! За коромя и Отечество!». 


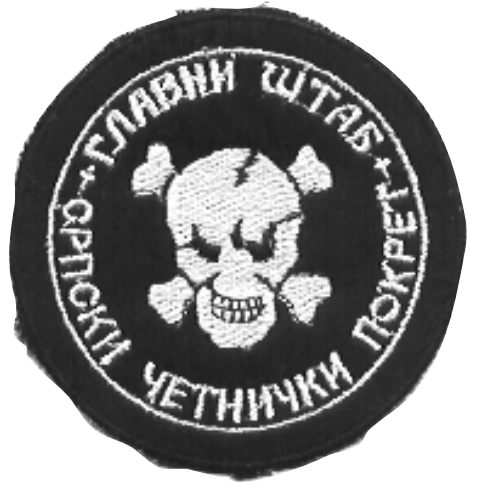

Рис. 1

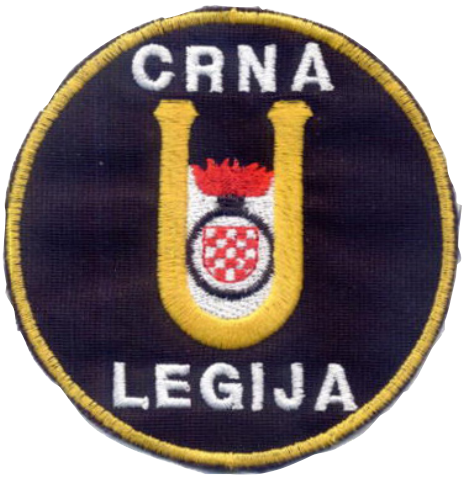

Pис. 2

Их символом была стилизованная матинская буква «U» (см. рис. 2). Аишь немецкие нацисты, союзники хорватов в независимом государстве Хорватия ${ }^{6}$, использовали изображение мертвой головы. В полувоенных формированиях хорватов был распространен скорее «пиратский» вариант черепа «веселый Роджер», а его более позАние поп-культурные модификации использовались на территории Боснии.

Существует мнение, что «мертвая голова», которую сербы избрахи знаком четнического Авижения, связана с изображениями на форме прусских «гусар смерти» (Totenkopfhusaren). Гусарские части в прусской армии действительно часто набирались из балканских славян. В русской армии череп и кости появились в символике 5-го мейб-гварАии гусарского АлексанАрийского полка. Тех, кто служил в нем, называли «черными» или «бессмертными» гусарами (гусарские подразделения в России также формировались из числа балканских славян). В Аанной статье мы не собираемся решать вопрос, кому принаАлежит приоритет в использовании этого символа. Аля нас в Аанном случае важнее его семиотическое наполнение.

Изображение черепа и костей, как правияо, служит напоминанием о жизни и преображении, а с Аругой - указывает на близость смерти (memento mori $)^{7}$. Во время войны эти значения нивелируются - кмючевой становится идея презрения к смерти и готовности принять ее во имя

6 Независимое государство Хорватия или НАХ (Nezavisna Država Hrvatska) - марионеточное государство, основанное усташами в 1941 г. с помощью стран Оси (нацистского блока) и их союзников.

7 Во многих традициях череп - это средоточие интемлекта, Ауха, жизненной энергии, а также часть тела, наиболее стойкая к разложению (символика, межащая в основе языческого культа черепа в Европе). ОтсюАа концепция vanitas: не просто как знака эпохи барокко, но символическая отсылка к предыдущему культурному тексту. 


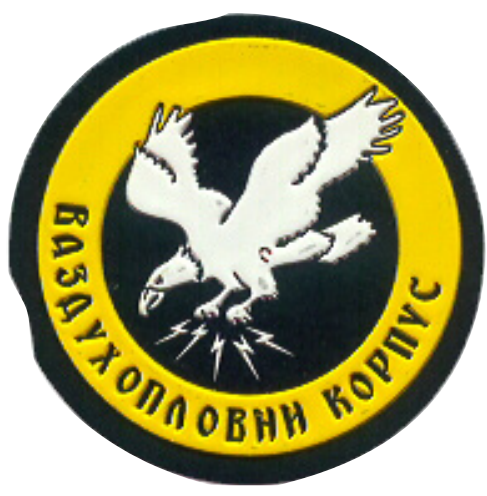

Рис. 3

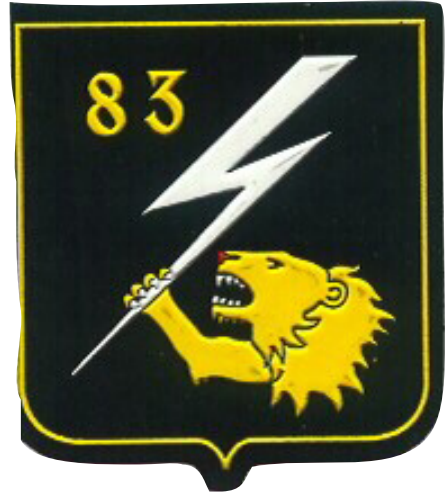

Pис. 4

победы. Кроме того, актуализируется восприятие себя как силы, несущей гибель врагам ${ }^{8}$. ЗАесь, таким образом, используется сочетание маркера Аля «своих», устрашающего маркера Аля «чужих» и функция оберега. Символ черепа и костей мог включаться в изображение, Аелая его более военизированным, более наступательным и агрессивным. Например, в символике государственной армии Югославии обнаруживаем присутствие четнического знака. Как видим, «военная» интерпретация символа не совпаАает с его исходной семантикой. Условия военного времени моАифицируют смысл знака, подчиняя его собственным нужАам. СХоАным образом обстоит Аело и с Аругими мортальными символами‥

Например, наряду с изображениями черепа и костей, использовались символы агрессии: мечи, молнии, кинжалы. Так, пикирующий сокол, выпускающий молнии, олицетворяет собой внезапность нападения и поражающую силу. Изображения мечей в еАинстве с хищными животными акцентирует смертоносность когтей или кмыков ${ }^{10}$. Но и зАесь есть спрятанные цитаты, отсылки к истории и идеологии. Например, стилизаторский характер молний на нашивках хорватских боевых отрядов - это прямая отсылка к нацистским изображениям (см. рис. 3). Но не только: они могут

8 Подобный смысл вкладывался и название одного из конных полков Петербургского ополчения, который в качестве своего обозначения име «серебряный череп наА скрещенными костями» и носии именование «Смертоносного» или «Бессмертного» полка.

9 Более подробно см. Антанасиевич, И. (2015). Мортальный коА в реалиях югославских войн. В: Мортальность в митературе и культуре. Москва: Новое китературное обозрение. С. 54-71.

10 Более полробно см. Антанасиевич И. (2011). Зооморфные символы в военных реалиях югославских войне. В: Временник Зубовского института.Грозное времл. Война в зеркале человеческого восприятия. Вып.: 6. Санкт-Петербург.: Российский институт истории искусств. С. 33-44. 


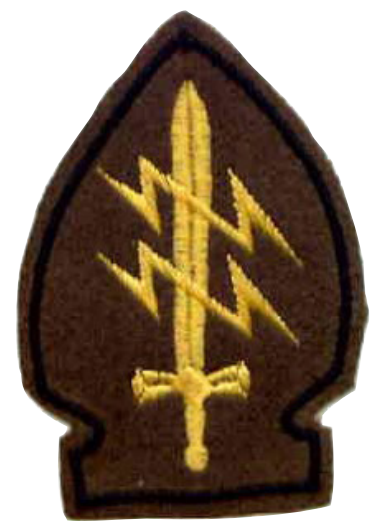

Pис. 5

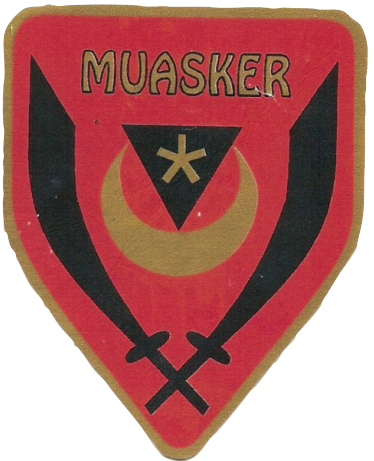

Рис. 6a

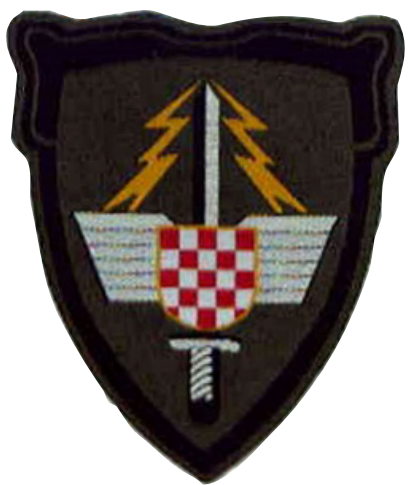

Рис. 66

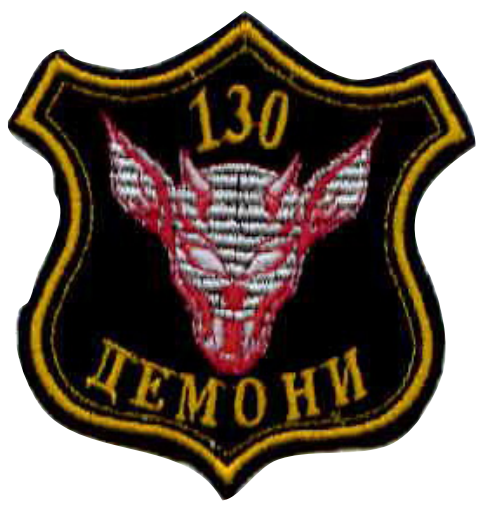

Рис. 7 быть в то же время и цитатой из корпуса массовой культуры (стилистика комикса) (см. рис. 4) или просто содержать семантику угрозы (см. рис. 5).

Образы мечей, кинжалов, кроме того, часто использовались и в тех случаях, когда бымо необходимо подчеркнуть оборонительный характер войны: например, эти орудия использовались как мусумьманской стороной (см. рис. 6а), так хорватской (см. рис. $6 \mathrm{~b}$ ) и сербской сторонами.

В основе визуального сообщения могло межать и изображение смерти, выраженное в виде ее визуальных «креатур» (см. рис. 7). Эти изображения яркий пример психологического возАействия на противника, заключающегося в идее запугивания, подавления его воли. Но чаще всего мортальность подавалась в символике поп-культуры, что «вкАючало» в себя игровой механизм войны, подчеркивало ее иррациональное начало. Подобные изображения делятся на Аве категории. Первая категория - это изображения, которые призваны только лишь подчеркнуть исключительность группы, к которой они принаАлежат. Это особенность, которая явмяется 




Pис. 8



Рис. 9

базовой Аля всех военных знаков. Например, использование образа героя комикса Фантома или такого образа, как месной Аух (см. рис. 8). Важно поАчеркнуть, что эта исключительность сознательно заземляется. Аелается это с целю приблизить игровое содержание реальности: например, Ааже при выборе комикс-героя из всего ряда супергероев выбирается именно Фантом, творение художника $\Lambda$ Фалька, - единственный супергерой, который собственно говоря не имеет никаких сверхъестественных сиц, а в бою опи-

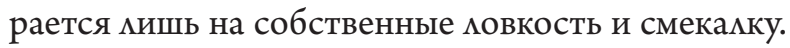

В свою очередь, вторая категория изображений, кроме базовой, имеет еще и Аополнительную семантическую наполненность: именно ту, игровую, о которой мы уже упомянули. Следует отметить, что такие «игро-

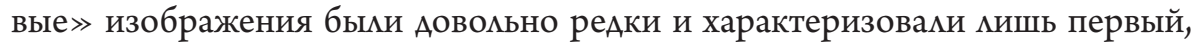
начахьный период войны. В этом ряду можно, например, упомянуть изображения маменьких ведьм (см. рис. 9). Подобные изображения - несомненная калька, заимствованная из частого использования слова «веАьма» военной авиацией периода Второй мировой войны - «ночные веАьмы», «крылатые ведьмы» и пр. СюАа же можно отнести гремлинов, которые также являются наследием мегенА периода Второй мировой войны ${ }^{11}$. Впрочем, рассматриваемое изображения гремлинов очевидно все же ближе не историческому периоду Второй мировой войны, а кинематографическому варианту: популярному в конце 1980-х годов фильму режиссера Ажо Аанте $\ll$ Гремлины $\gg^{12}$.

11 Принято считать, что само название гремлин впервые появилось в 1940 годы в среАе английских метчиков. Первой публикацией о них считается рассказ в журнале Royal Air Force Journal от 18 апремя 1942 года, а в 1943 писатель Роаць Ааль пишет повесть «Гремлины».

12 См. https://www.imdb.com/title/tt0087363/ 


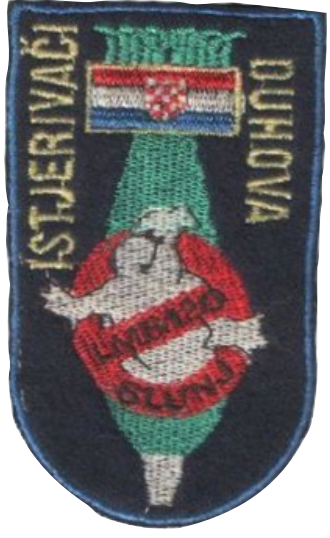

Рис. 10



Puc. 11

Кинематографический образ становится определяющим и Аля появления изображения «Аухи» (см. рис. 10). Он взят из американского фильма «Охотники за привидениями» режиссера Айвана Райтмана (в переводе на сербский фильм звучит как «Истеривачи Аухова ). Аанный, конечно же игровой, образ, несомненно, базовый: он поАчеркивает неуловимость его носителя, его неуязвимость. С оАной стороны, характер изображения некоторым образом «переключает» механизм военного соперничества, внося в него элемент соперничества игрового (на

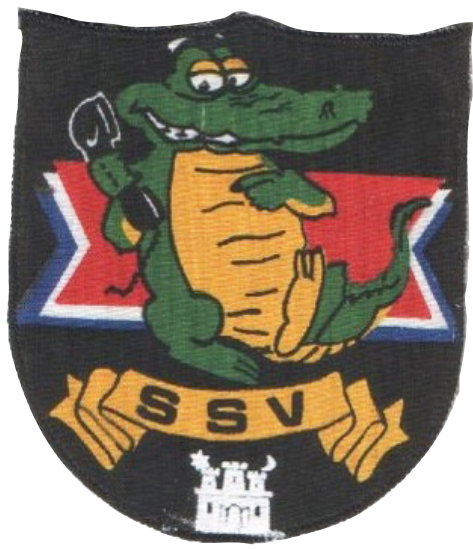

Рис. 12 уровне игры в «партизан - немец», «ковбой- индеец», «полицейский - вор» и пр.). Это, с оАной стороны, определенным образом «сближает» воюющие страны, уравнивает их в рамках реальности войны, которая, таким образом, превращается в игру, в охоту, но, с Аругой стороны, в который раз подчеркивает их непримириМость и иАеологические разАичия.

Схожим образом обстоит Аело и с символами, взятыми из мультфильмов. В качестве примера можно привести образ тасманского Аьявола по имени Таз (см. рис. 11) - персонажа мультфильмов компании Warner Bros. Основой Аля его выбора послужики такие его характеристики, как быстрота и наличие кмыков, угрожающего виАа. Таким образом, он, как и изображения хищных животных, Аолжен был манифестировать то, что он несет смерть Аюбому, против кого он выступает. Приблизительно в этом 
же контексте употребляется изображение Крокодияа - персонажа из детской книги Корнея Чуковского, которая была Аовольно попуяярна на территории Балкан: телефонная трубка, которую персонаж Аержит в руке знак связи, поскольку изображение использовали связисты (см. рис. 12).

Как мы виАим, в исследовании феномена шеврона как знака войны огромную роль играет исслеАование символа, поскольку тогАа становится возможен процесс считывания культурных кодов. Это в результате Аает возможность описать функционирование самого военного сообщества и механизм возАействия знака на эту структуру, которая преАстает переА нами как целостная и самоорганизующаяся система. Кроме того, мы видим, что знаки войны всегАа исходят из универсацьных смыслов, но обогащают их Аокальными, иногАа Аовольно архаичными культурными смыслами.

\section{Литература}

Кайуа, Р. (2003). Война и сакральное. В: Миф и человек. Человек и сакральное. Москва: ОГИ. С. 76-91.

\section{Popkultūra un kara zīmes}

Rakstā aplūkotas kara piedurkṇu uzšuves kā pazišanās sistēmas savs-svešais marḳieri. Piedurkṇu uzšuvēm ir duāla daba, jo tās vienlaicīgi attiecas uz divām kategorijām savējiem un svešajiem. Izpētes materiāls ir Dienvidslāvijas kara beigu piedurkṇu uzšuves, ko Balkānu teritorijā izmantoja serbi un horvāti (20. gadsimta 90. gados). Šì laika posma uzšuvēs aktīvi izmantoti masu kultūras (galvenokārt amerikāṇu) tēli un personāži.

\section{Pop-culture and Signs of War}

The article focuses on the problem of military chevron (insignia) as an "our" "other" semiotic marker. Chevron has a dual nature. It simultaneously addresses both categories: "ours" and "others". The research is based on the corpus of Yugoslavia's chevrons used in the period of Yugoslavia's war and military conflicts at the end of 1990s on the territory of Balkan region. The research specifically targets chevrons of Serbian and Croatian military forces. The analysis allows concluding that Yugoslavian chevrons of that period actively borrow images and characters from (American first of all) pop-culture. 
Лингвистика 
DOI: http://doi.org/10.22364/ruslat.glp.14

\section{Ольга Горицкая}

\section{Русский язык в Беларуси и других постсоветских странах: споры о терминах ${ }^{1}$}

В статье предпринимается попытка систематизировать русскоязычную терминологию, описывающую специфику русского языка в Беларуси и Аругих постсоветских странах (выбор слов Аля обозначения идиома). Освещаются семантические и стилистические особенности терминов, а также социально-политические проблемы, связанные со словами (лингвистическая манифестация независимости страны, язык и нация и т.п.). В работе обосновывается, что русский язык относится к полицентрическим, и указывается на существование доминантной (российской) и недоминантных (в т.ч. белорусской) разновидностей русского языка, которые находятся в процессе становления и развития.

Кмючевые слова: русский язык, полицентрический язык, национальный вариант языка, национальная разновидность языка, региональный вариант языка, региональная разновидность языка

\section{Введение}

ОбсужАая специфику русского языка в разцичных странах, в т.ч. на постсоветском пространстве, мингвисты используют множество обозначений, причем иногАа Ааже в оАной и той же работе используются разАичные термины. Перечислим основные из них:

- Русский язык / русская речь (в) Беларуси, Казахстане, Украине, Аатвии и т.п.;

- Белорусский и т.п. русский (язык);

- Белорусский и т.п. национальный/региональный вариант русского языка (ими же разновидность);

- Белорусский и т.п. нациолект/этнолект/региолект/диалект русского языка.

Кроме того, русский язык в конкретной стране противопоставмяется русскому языку в России как языку метрополии.

1 Работа выполнена при подАержке гранта Белорусского республиканского фонда фундаментальных исследований (Г18М-062). 
ИногАа некоторые из слов в составной номинации берутся в кавычки, Аемонстрирующие неузуальный или спорный характер термина: «белорусский» русский, белорусский «вариант» русского языюка и т.п.

Разнообразие терминов обусловлено переходным характером описываемого идиома ${ }^{2}$ и сосуществованием в обществе размичных мингвистических идеологий. Приведем в качестве примера словарную статью поА названием «Национальные варианты русского языка» из (Словарь социолингвистических терминов 2006: 146): «Специфические разновидности русского митературного языка, возникшие в зонах активного контактирования русского и Аругих языков, прежде всего на территории основных языков союзных республик СССР, занимающие, с точки зрения социолингвистики, промежуточное положение между национальными вариантами митературного языка и этнолектами. <..> Среди русистов и социолингвистов существовали разногласия в том, как оценивать такие региональные варианты русского языка. Большинство мингвистов скмонямось к мнению, что Н.в.р.я. ${ }^{3}$ нельзя узаконить и считать равноправными, таким образом, преобмадала негативная оценка "местных" разновидностей ("среднеазиатского", “кавказского”, “прибалтийского” и Ар.) русского митературного языка, разрушающих его еАинство как среАства межнационального общения, что потенциально могло вести к языковой дезинтеграции общества».

Употребляя такие термины, как русский язык/русская речь (в) Беларуси, белорусский русский и т.п., авторы, по сути, уходят от ответа на вопрос о природе Аанного идиома, поэтому данные терминологические сочетания вызывают меньше всего возражений. ОАнако гцубокое исследование, касающееся особенностей функционирования русского языка в размичных странах, невозможно без постановки вопроса: как стоит квалифицировать этот иАиом? При этом очевиАно, что попытка ответить на Аанный вопрос и назвать идиом национальным или региональным вариантом языка, этнолектом и т.п. ведет к постановке новых вопросов.

Конфликт понятий нередко оказывается обусловленным социально-помитическими обстоятельствами. Рассмотрим в качестве примера высказывание белорусского языковеда В. Вечёрко: «Российские языковеды уже говорят про беморусский вариант русского языка, называют его национальным диалектом, нациолектом. А те, кто считают Беларусь регионом Русского мира, называют региональным диалектом или региолектом» (Вячорка 2016), см. также полемику в работах (РуАяков 2010; Степанов 2010; Теркулов 2012 и Ар.).

2 В Аанной статье обозначение идиом используется как «общий термин Аля обозначения различных языковых образований - языка, Аиалекта, говора, мит. языка, его варианта и Ар. форм существования языка» (Виноградов 1990: 171). Аанный термин часто используется аля номинации языковых образований со спорным статусом (там же).

3 Национальные варианты русского языка. 
Цель Аанной статьи - упорядочить терминологию, описывающую особенности русского языка в Беларуси и на фоне Аругих постсоветских госуаарств.

Материалом Аля исследования послужили русскоязычные научные публикации, описывающие русский язык в различных странах бывшего СССР. ВвиАу ограничений на объем статьи мы приводим мишь ссылки на некоторые работы.

\section{Вариант, разновидность языка или диалект?}

Русский язык в Беларуси иногАа называется белорусским вариантом русского языка - из свежих работ см. (Мечковская 2018), что помещает Аанный идиом в круг (национальных) вариантов типа американского английского (Швейцер 1971 и Ар.). ОАнако использование термина вариант при обозначении иАиомов порожАает некоторые стилистические и семантические проблемы. Это связано с тем, что вариантами могут называться как отдельные языковые единицы, так и идиомы. А поскольку в работах, посвященных специфике языка в той или иной стране, часто изучаются вариативные языковые факты, то неоднозначность терминов становится очевидной: исследователи анализируют фонетические, мексические или грамматические варианты в определенных вариантах языка. Подобной Авусмысленности нет в английском языке, гАе Аля обозначения иАиомов, как правимо, испомьзуются термины типа variety, а Аля номинации языковых фактов - variant и ар.

Иногда идиомы типа белорусского русского называются национальными диалектами, см., в частности (Аисковец 2018). ОАнако это обозначение вряА $и$ является УАачным, поскольку сегодня термин диалект ассоциируется с траАиционными территориальными (преимущественно сельскими) Аиалектами, корни которых уходят в глубокую Аревность, а особенности русского языка в Беларуси, Украине, странах СреАней Азии и т.п. обусловмены контактами размичных языков в более позАние эпохи. Кроме того, традиционные Аиалекты и иАиомы типа белорусского русского различаются по сфере использования.

Слово разновидность реже встречается в научных работах, где рассматривается вариативность в языках, на которых говорят в разных странах. У него нет очевидной ассоциации с такими разработанными идиомами, как американский английский, поэтому обороты типа белорусскал разновидность русского языка вызывают несколько меньше возражений у мингвистов, выступающих за единство норм русского языка. Некоторая размытость Аанного термина позволяет включать описываемый термином иАиом в широкую сеть жанровых, стилистических и Аругих разновидностей языка (Мустайоки 2013). В целом нам представляется целесообразным более широко употреблять слово разновидность в качестве аналога английского variety, в т.ч. Аля обозначения разновиАностей русского языка в таких странах, как Бемарусь или Казахстан. 


\section{Региональный или национальный?}

Более острые дискуссии вызывают определения к словам разновидность или вариант, поскольку обозначения национальный и региональный связаны с множеством социально-политических проблем.

Региональный, региолект. Использование терминов региональный вариант, региональная разновидность или региолект вписывает разновидности русского языка в размичных странах и частях России в общее языковое пространство: «Те языковые разновидности, которые функционируют на Украине, в Казахстане и т.А., могут быть определены сейчас только как региолекты единого русского национального языка» (Теркулов 2012); поАобная точка зрения преАставлена также в (Степанов 2010). А такое Аингвистическое еАинство начинает ассоциироваться со стремлением к политическому еАинству, что может вызывать возражения.

Вообще, слово регион редко обозначает конкретное государство и в целом имеет достаточно размытое значение, см., например, определение из словаря: «Обширный район, группа сосеАствующих стран или территорий, объединенных по нескольким общим признакам (географическим, экономическим, политическим) (Большой толковый словарь 2000: 1110). Кроме того, мексема регион (как правимо, в форме мн.ч.) и его производные используются в современных текстах аля противопоставления столицы Аругим частям страны, что приводит к появмению у Аанной еАиницы таких же коннотаций, как у слова провинция.

Проиляюстрируем коннотации слова региональный. В оАном из беморусских электронных СМИ вышла статья, гАе говорилось следующее: Интернет-журнал о Минске CityDog.by стал победителем в номинации «Peгиональные тематические и развлекательные издания» (CityDog.by 2017). Несколько примеров из комментариев к этой статье:

- Минск уже считается российским регионом? Неплохо.

- Фуфуфу... провинциальные (читаем: региональные) ресурсы. Ни стыла, ни гордости...

Аналогичная проблема возникает с обозначением русского языка в России как языка метрополии, так как слово метрополия имеет очевидную (пост)колониальную окраску. При этом показательно, что симметричное обозначение стран, противопоставленных метрополии, не фиксируется в текстах, поскольку колоний, как и империи, формально нет, но соответствующая картина мира в той или иной степени сохраняется.

ИногАа в качестве синонимичных используются термины региональный вариант (региональнал разновидность) русского лзыюка и региолект. ПослеАний термин обозначает городскую речь со слеАами влияния местных Аиамектов и просторечия, см. также (САоварь социолингвистических терминов 2006: 180). Вспомним известное высказывание А.С. ГерАа: «Аиалекты не умирают, а трансформируются в региолекты» (ГерА 2005: 22). Но в Беларуси, Украине, Казахстане и Аругих постсоветских странах наблюдаются контакты разных языков, а не только форм существования одного языка 
(Аиалектов, просторечия, митературного языка), поэтому использование термина региолект по отношению к описываемым в нашей статье идиомам вряА Аи можно считать УАачным.

Национальный, этнический, нациолект, этнолект. Споры о терминах в Аингвистических работах часто Аемонстрируют конфмикт интерпретаций оАного и того же понятия. Особенно много споров вызывает слово нация. Объем Аанной статьи и ее цель не делают возможным детально обсужАать это фундаментальное понятие. Отметим мишь, что попытка Аать четкое определение нации вряд ми может быть успешной. Процитируем А.И. Мимлера: «Подчеркну еще раз - в этой книге не нужно искать ответа на вопросы “что такое нация?" или “какое опредекение нации верное?”. Автор убежАен, что эти вопросы не имеют ответов именно потому, что это понятие играет столь важную, центральную роль, и всякий, кто пытается Аать такое определение, вынужАен занять политическую, то есть партийную, частную позицию. Можно сказать иначе: это понятие потому и может играть столь значимую роль, что не поддается четкому опредемению, являясь "живым" и находящимся в постоянной динамике» (Мимер 2016: 12).

Так, кто-то из мингвистов, пишущих о русском языке в размичных странах, отождествляет нацию и этнос, см., например, (Теркулов 2012), а кто-то подразумевает поА нацией политическую общность мюАей (Журавлева 2015 и Ар.). Эту неоднозначность можно было бы снять введением терминов с компонентом этнический, например, этнолект, оАнако и они используются Аля номинации разцичных иАиомов: канадского французского, Аагестанского русского, иАиша, который рассматривается как этнолект немецкого языка, а также пиАжинов, см. обсуждение в (Перехвальская 2008: 168-169). КогАа речь илет о национальных разновидностях (или - в Аругой терминологии - вариантах) языка, то обычно имеется в виду как раз политическая общность, поскольку рассматриваются особенности использования языка житемями какого-либо государства. При этом этнический состав русскоязычных может различаться по странам. Например, в Беларуси большинство Аюдей, говорящих по-русски (в абсолютных величинах), - это этнические белорусы (Перепись населения 2009), в то время как в некоторых Аругих постсоветских странах русский язык может использоваться главным образом этническими русскими. А значит, употребцять термины типа этноязык применительно к разновидностям русского языка на всем постсоветском пространстве вряА $и$ целесообразно.

Слова нация, национальный и особенно национализм имеют множество коннотаций, вызванных сложной историей соответствующих понятий. Подчеркнем, что в Беларуси и в ряде Аругих постсоветских стран использование слова национальный по отношению к русскому языку вызывает возражения, поскольку опреАеление национальный традиционно используется применительно к языку титульной нации, выполняющему символическую и этноконсолидирующую функции (Мечковская 2003: 124), см. также анализ 
взаимодействия разАичных языковых идеологий в белорусском обществе в (Goritskaya 2018a).

ОтАельно стоит сказать о термине нациолект, который особенно часто используется применительно к белорусскому русскому. Аанное обозначение появилось в советское время и обозначало некодифицированные разновидности русского языка в размичных советских республиках, в частности в БССР (Михневич, Гируцкий 1982). Конструирование термина нациолект было вызвано желанием противопоставить некодифицированные разновиАности русского языка в странах СССР кодифицированным разновианостям испанского, английского или немецкого языков. В целом Аля работ советского времени была характерна моноцентрическая ориентация (стремление следовать еАиным Аля всего СССР нормам): «Языковая политика в отношении БНРЯ 4 (как и в отношении всех иных "нациолектов”) заключается в том, чтобы всеми организационными научными, методическими и иными среАствами соАействовать его сближению с русским митературным языком, в чем, по существу, и состоит заАача Аостижения полного, гармонического, равноправного несмешанного (автономного, координативного) белорусско-русского Авуязычия» (там же: 79). Впрочем, в современных работах наличие митературной нормы не всегАа считается необходимым условием для выделения национального варианта языка, см., например, статью «Национацьный вариант языка» из (Смоварь социомингвистических терминов, с. 147).

А.А. Сомин остроумно назвал термин нациолект регионализмом (Сомин 2013). И Аействительно, это обозначение часто используется в работах белорусских авторов, а оттуда проникает в зарубежные публикации по белорусской проблематике (например, в работы Г. Хентшемя или К. Вумхайзера). Слово нациолект имеет прозрачную внутреннюю форму и хорошо вписывается в существующую систему мингвистических терминов, поэтому его аналоги (natiolect) встречаются и в работах про разновиАности Аругих языков, используемых в нескольких странах, например, бельгийской разновидности нидерландского языка (G. Laureys и Ар.).

ОАнако, по нашему мнению, противопоставление терминов национальный вариант (разновидность) языка и нациолект сегодня вряА ми является необходимым. КоАификация - это в первую очереАь символический акт, который свидетельствует о высокой степени осознанности языковых отАичий, их значимости Аһя иАентичности, а также укорененности идеи о множественности норм, относящихся к разновиАностям того ими иного языка, в социуме. Кроме того, роль коАификации в современном обществе меняется ввиду тенденции к демократизации и использованию новых способов распространения информации (в первую очередь интернета). Так, в отличие от США, Австрахии и Аругих стран, в Беларуси мингвисты не занимаются кодификацией вариантов, специфичных Аля белорусской

4 Белорусского нациолекта русского языка. 
разновидности русского языка. ОАнако это не мешает мюАям использовать некодифицированные еАиницы, к примеру, варианты беларус и бела-

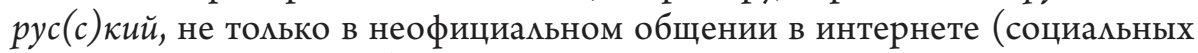
сетях, блогах, форумах), но и в СМИ, художественной митературе, рекламе. На страницах электронных СМИ веАутся Аискуссии о функционировании некодифицированных вариантов, специфических Аля иАиома, а также дается множество примеров использования ненормативных языковых еАиниц, и новые варианты начинают распространяться в речевой практике. Этот новый Аля русскоязычного коммуникативного пространства феномен может быть назван «народной» коАификацией (Goritskaya 2018 b). Безусловно, такое поведение не характерно Аля всего населения Беларуси, потому что в целом в постсоветских странах сохраняется достаточно консервативное отношение к языковому стандарту, но ростки нового отношения к нормам, безусловно, нужАаются во внимании и теоретическом осмыслении.

На основании всего вышесказанного мы полагаем, что целесообразнее было бы использовать общий термин Аля языковых разновидностей, которые являются в большей и в меньшей степени разработанными, в частности, Аля кодифицированных и некодифицированных, поскольку это позвоцяет сопоставцять идиомы, находящиеся на разных этапах развития, и видеть общую картину функционирования разновидностей языков в Аинамике, см., в частности (Muhr 2012), о развитии разновидностей языков, используемых в нескольких государствах, как стадиальном процессе.

Рассмотреть иАиомы типа американского английского или белорусского русского в еАиной системе позволяет концепция полицентрических (pluricentric) языков (W. Stewart, H. Kloss, M. Clyne, R. Muhr и ар.). Мы принимаем точку зрения, согласно которой к полицентрическим относятся языки, которые используются преАставителями размичных (как минимум Авух) наций в нескольких государствах (Pluricentric languages 1992; Muhr 2012 и Ар.). Разновидности полицентрических языков имеют ряд характеристик (чем больше условий соблюдается, тем более развитым считается иАиом). Первой из этих характеристик явмяется официально закрепленный статус языка в стране. Кроме того, разновидности могут размичаться в структурном отношении, при этом Аистанция межАу иАиомами может быть большей или меньшей. Представители языкового комлектива могут принимать или не принимать полицентризм. В некоторых странах особенности конкретной разновидности языка изучаются в школе, а госуАарство занимается развитием идиома.

Русский язык также можно отнести к полицентрическим. При этом разновидности русского языка в разцичных постсоветских странах имеют социолингвистическую (статус русского языка не явцяется одинаковым на всем постсоветском пространстве (Pavlenko 2008; Мечковская 2011; del Gaudio 2013 и Ар.)) и структурную специфику, которая во многом обусловмена контактами русского и Аругих языков, а также реализацией потенций, 
заложенных в системе русского языка, в разцичных социокультурных условиях, см., к примеру, (Горицкая 2018) о русском языке в Беларуси.

Как отмечалось выше, русский язык кодифицируется только в России, и соответствующая разновиАность явмяется неАоминантной. Белорусская разновидность русского языка относится к неАоминантным: Беларусь ориентируется на российский языковой стандарт, там проживает меньше русскоязычных, чем в России, а структурные особенности, характерные Аля иАиома, не в полной мере осознаются носителями.

Таким образом, оба определения к слову разновидность - и национальныцй, и региональный - не являются четко определенными, кроме того, они нагружены различными коннотациями. На наш взгляА, Аля обозначения разновидностей русского языка, используемых в суверенных странах, кучше использовать термин национальный - с учетом существующей в мингвистике традиции, а также политических обстоятельств (независимости государств). Необходимо также учитывать важность понятия нация Аля описания общественно-политической жизни: «3а послеАние 30 мет в науках об обществе “нация” постепенно перестала выполнять функцию “объясняющего" понятия. Подобно тому, как это произошио с понятием “идентичность”, “нация” теперь воспринимается, прежде всего, как проблема, требующая объяснения. <...> Это, пожалуй, в интелмектуальном смысле самая продуктивная ситуация, когАа понятие уже подвергнуто Аеконструкции и перестает играть ромь своеобразной, якобы магической, а на самом Аеле - Аеформирующей и мутной призмы. Это, конечно, не значит, что в помитической жизни понятие “нация” перестанет играть центрацьную роль. Нацию можно понимать как социальный оператор или как способ илентификации, как главную ценность, как миф, символ, ресурс мегитимации, Ааже как “историческую общность”, но, как бы то ни бымо, позиция неучастия в Аискуссии о том, что такое национальные интересы, какой Аомжна быть нация и т.п., - это путь к политической маргинальности» (Мимеер 2016: 130). А слово региональный можно оставить Аля обозначения особенностей разновидности языка в различных частях отАельно взятой страны.

\section{Выводы}

Выбор терминов в социолингвистических работах оказывается особенно сложным, поскольку язык связан с иАеологией, иАентичностью, вмастью и Аругими социально-политическими феноменами. Мы полагаем, что кмючевые свойства удовлетворительного социолингвистического термина - это его максимальная нейтральность, универсальность и общепонятность, а также связь с теорией, позволяющей адекватно описывать исследуемое социолингвистическое явление и помещать его в мировой контекст (если таковой существует). Аля рассмотрения русского языка в разАичных странах, на наш взгляА, подходит концепция полицентрических языков, которая позволяет сопоставмять иАиомы, находящиеся на различных этапах обособления и развития. 
Понятно, что обозначения типа белорусскал или казахстанскал (национальная) разновидность русского языка не явмяются идеальными. В частности, они могут вызывать возражения у мингвистов с моноцентрическими установками. ОАнако наличие в профессиональном сообществе и в социуме в целом Аискуссий по актуальным вопросам является естественным.

В (пост)советской мингвистике достаточно распространена точка зрения, согласно которой ярлыки типа начиональная разновидность или национальный вариант можно использовать только применительно к разработанным идиомам с набором устойчивых (и желательно кодифицированных) характеристик. ОАнако количество структурных размичий и Ааже стабильность структурных черт не может считаться основным критерием Аля выАеления отдельных разновиАностей полицентрических языков. Аингвисты Аавно привыкли к тому, что граница между языком и Аиалектом является условной, и, на наш взгляА, необходимо применять этот неАискретный поАхоА, учитывающий влияние социальных факторов, к Аругим идиомам.

Аумается, что сегодня специалистам, работающим в области дескриптивной Аингвистики, слеАует проАвигать нейтральный взгляА на языки и их разновидности, а также на вариативность в целом. При этом необхоАимо осознавать, что социолингвист не может быть абсолютно нейтральным. ЕАинственный выхоА - постоянная рефлексия, в том числе и наА используемыми понятиями.

\section{Литература}

Большой толковый словарь русского языка (2000). Кузнецов, С.А. / гм. реА. СанктПетербург: Норинт. 1536 с.

Виноградов, В.А. (1990). ИАиом. В: Аингвистический энциклопедический словарь. Ярцева, В.Н. / гл. реА. М.: Советская энцикмопедия. С. 171.

Вячорка, В. (2016). Чаму расейцы не разумеюць слова «ссабойка»: віАэа. Па-беларуску зь Вінцуком Вячорам, 30 чэрвеня 2016. Ааступны на 20.08.2018: https://www. svaboda.org/a/27830780.html

ГерА, А.С. (2005). Введение в этнолингвистику. Санкт-Петербург: ИзАательство СанктПетербургского университета. 457 с.

Гируцкий, А.А., Михневич, А.Е. (1982). О языковом и мингвистическом статусе «нациолекта». В: Вариативность как свойство языковой системы: тезисы докладов. Москва: Наука. Ч. 1. С. 77-79.

Горицкая, О.С. (2018). Аексические особенности русского языка в Беларуси не связанные с влиянием белорусского языка. Respectus Philologicus, No. 34 (39). C. 48-60.

Журавлева, Е.А. (2015). Русский язык в Казахстане: варьирование и функиионирование. Астана: KazServisePrint. 200 c.

Аисковец, И.В. (2018). Русско-белорусское переключение кодов в г. Минске. Коммуникативные исследования. № 1 (15). С. 85-96.

Мечковская, Н.Б. (2003). Белорусский язык: сочиолингвистические очерки. Mӥnсhen. Verlag Otto Sagner. 163 c. 
Мечковская, Н.Б. (2011). Постсоветские языки в условиях государственного суверенитета и расцвета информационных технологий. Веснік БАУ, серыя IV. № 2. C. $75-82$.

Мечковская, Н.Б. (2018). Белорусская «трасянка» как яблоко раздора и как оселок метода. Русский язык в научном освещении. № 1 (35). С. 226-250.

Мимер, А.И. (2016). Нация, или Могущество мифа. Санкт-Петербург: ИзАательство Европейского университета в Санкт-Петербурге. 146 с.

Мустайоки, А. (2013). Разновидности русского языка: анализ и классификация. Вопросы языкознания. № 5. С. 3-27.

Перепись населения 2009 г.: Национальный состав населения Республики. Т. 3. Минск: Информационно-Вычислительный центр Национального статистического комитета Республики Бемарусь, 2011. 433 с.

Перехвальская, Е.В. (2008). Русские пиджины. Санкт-Петербург: Алетейя. 363 с.

РуАяков, А.Н. (2010). Георусистика и мингвистические механизмы формирования национальных вариантов языка. В.: Язык и общество в современной России и других странах: международная конференция (Москва, 21-24 июня 2010 г.): доклады и сообщения Виноградов, В.А., Михальченко, В.Ю. / отв. реА. Москва. С. 56-58.

Словарь сочиолингвистических терминов (2006). Москва: Институт языкознания РАН. $312 \mathrm{c}$.

Сомин, А.А. (2013). Русский язык в Республике Беларусь. В: Русский язык зарубежкья. Санкт-Петебург: ЗАатоуст. С. 171-201.

Степанов, Е.Н. (2010). Национальные варианты русского языка ими русские территориальные койне? Мова. № 16. С. 9-14.

Теркулов, В.И. (2012). Региолект ими национальный вариант: к постановке проблемы. Филология и культура. № 2 (28). С. 117-120. Аоступен на 20.08.2018: http://www. philology.ru/linguistics1/terkulov-12.htm/

CityDog.by (2017). Шикарно! CityDog.by стал победителем международной премии Амя интернет-медиа «Медиатор». CityDog.by, 30.04.2017. Аоступен на 20.08.2018: https://citydog.by/post/win-win/

Del Gaudio, S. (2013). Russian as a non-dominant variety in post-Soviet states: a comparison. In: Exploring Linguistic Standards in Non-Dominant Varieties of Pluricentric Languages. Muhr R. et al. / eds. Frankfurt am Main, etc.: Peter Lang Verlag. Pp. 343-363.

Goritskaya, O. (2018a). Discussions about Belarusian Russian: linguistic units and cultural models. In: The Explicit and the Implicit in Language and Speech. Liashchova, L. / ed. Newcastle upon Tyne: Cambridge Scholars Publishing. Pp. 190-222.

Goritskaya, O. (2018b). In search of identity: a corpus-based study of lexical variation in Belarusian Russian. In: Pluricentric Languages and Non-Dominant Varieties Worldwide: New pluricentric languages - old problems. Muhr, R., Meisnitzer, B. / eds. Wien u.a.: Peter Lang Verlag. Pp. 219-231.

Muhr, R. (2012). Linguistic Dominance and Non-Dominance in Pluricentric Languages. A Typology. In: Non-Dominant Varieties of Pluricentric Languages. Getting the Picture Muhr, R. et al. / eds. In Memory of Prof. Michael Clyne. Wien u.a.: Peter Lang Verlag. Pp. 23-49.

Pavlenko, A. (2008). Russian in post-Soviet countries. Russian Linguistics, 32. Pp. 59-80. Pluricentric Languages. Different Norms in Different Countries (1992). Clyne, M.G. / ed. Berlin/New York: Mouton/de Gruyter. 481 p. 


\section{Krievu valoda Baltkrievijā un citās postpadomju valstīs: diskusija par terminiem}

Rakstā sistematizēta krievu valodas terminologija, kas atklāj krievu valodas specifiku Baltkrievijā un citās postpadomju valstīs (vārdu izvēle idiomas apzīmējumam). Autore aplūko terminu semantiskās un stilistiskās īpatnības, kā arī sociāla un politiska rakstura problēmas, kas ir saistìtas ar terminu lietojumu (valsts neatkarības lingvistiskā manifestācija, valoda un nācija u. c.). Krievu valoda ir policentriska, Baltkrievijā eksistē dominējoši (Krievijas) un nedominējoši (Baltkrievijas) krievu valodas paveidi, kas atrodas attīstības stadijā.

\section{Russian in Belarus and Other Post-Soviet States: Debates on Terms}

The paper attempts to systematize the terms denoting varieties of the Russian language in Belarus and other post-Soviet countries. The terminology from linguistic publications in Russian is analysed. The research focuses on semantic and stylistic features of the terms, as well as social and political issues associated with these words (linguistic manifestation of country's independence, links between language and nation, etc.). The paper claims that Russian is one of the pluricentric languages and contrasts the dominant (Russian) with non-dominant (including Belarusian) varieties of the Russian language that are developing now. 
DOI: http://doi.org/10.22364/ruslat.glp.15

Татьяна Савчук

\section{Семантико-прагматические ошибки в научной аргументации (на материале русских и белорусских гуманитарных текстов)}

В статье преАставлен результат могико-лингвистического анализа русско- и беморусскоязычного научно-гуманитарного Аискурса. Систематизируются семантико-прагматические ошибки, источником которых явцяется неадекватное использование языковых среАств вслеАствие нарушения принципа интерпретируемости. Характеризуются такие виды девиаций, как семантическая деформация, категориальный сАвиг, семантический сбой, референциальная неопределенность, семантико-прагматический Аиссонанс и Ар. Описываются механизмы возникновения этих погрешностей, обосновывается их семантико-прагматическая природа.

Ключевые слова: аргументация, аргументативная ошибка, научно-гуманитарный Аискурс, русский язык, беморусский язык

\section{Введение}

Исследование аргументации - особой интемлектуально-коммуникативной Аеятельности, связанной с прагматикой убежАения, - преАполагает не только описание аргументативного Аискурса, но также его критический анализ и оценку. Критический подход к аргументирующему рассужАению предусматривает установление критериев его правильности и созАание типологии ошибок. Как отмечают аргументологи, разработка «адекватных ПоАходов к определению разАичных виАов ошибок и соответствующих методов их идентификации в реацьных аргументативных практиках» явцяется приоритетным направлением современной теории аргументации (van Eemeren et al. 2014: 25).

Опыт изучения аргументации в нормативном аспекте имеет давнюю традицию, восходящую к трудам Аристотемя, таким как «Топика», «Риторика», «О софистических опровержениях $\gg^{1}$. Вместе с тем универсальная и общепризнанная теория аргументативных ошибок Ао сих пор не созАана. Объясняется это, прежАе всего, размичием исслеАовательских подходов к Аанной проблеме. Кроме того, Аискурсивные практики настолько многообразны и специфичны, что стандарты их критического измерения еАва $\Lambda и$

1 Ретроспективный обзор теоретических подходов к нормативному исследованию аргументации см. в: (van Eemeren 2001: 135-164). 
поААаются унификации. В этой связи особую важность приобретает созАание нормативных концепций, ориентированных на определенные типы Аискурса.

Объектом нашего исследовательского интереса явмяется аргументация в Аискурсе гуманитарных наук. Согласно авторской концепции, критический анализ научно-гуманитарного Аискурса производится на трех уровнях рациональности: структурном, вербально-семантическом и стратегическом. В фокусе Аанной статьи находится языковой уровень аргументирования. В работе ставилась цель эксплицировать нормы вербального преАставления аргументации, систематизировать ошибки, допускаемые в аргументирующем рассуждении. Анализ проводился на материале научных статей по различным направлениям гуманитаристики (социологии, психологии, культурологии, мингвистике, журналистике), опубликованных в рецензируемых журналах за 2001-2015 гг. Фактологическая база включает 300 научных текстов: 150 на русском языке и 150 на белорусском языке. Основным методом исследования стал могико-лингвистический анализ; были использованы также Аискурс-анализ и метод интерпретации.

Наша нормативная модель строится с учетом общезначимых характеристик аргументации (см., напр., Брутян 1992: 9-24), а также специфических свойств письменного научно-гуманитарного дискурса, таких как высокий уровень рациональности, ответственности и аргументативной компетентности участников, цемевая установка на кооперативное взаимодействие, преАварительная продуманность и подготовменность коммуникации.

Опорой А^я нашей теории послужили: известный Принцип кооперации Г.П. Грайса (Grice 1975: 41-58); общий Принцип коммуникации, разработанный Ф.Х. ван Еемереном и Р. Гроотендорстом: «Будь ясным, честным, эффективным и точным» (ван Еемерен, Гроотендорст 1992: 50-57); сформулированные Аж. Аичем Принципы текстопостроения: перерабатываемости, ясности, экономии, выразительности (Leech 1983: 63-70), а также признанные в общей теории коммуникации, теории речевого возАействия и аргументологии конвенции и правила общения (Аемьянков 1982: 327-337). Кроме того, мы учитывали результаты наблюАений и выводы, сАеланные мингвистами в рамках «ортологии научной речи» (см., напр.: Киримлова 2015; Матвеева 2000; Чернявская 2011)².

2 Заметим, что попытка языковедческой разработки критериев нормативности затрагивает преимущественно один аспект - метатекстовую коммуникацию. В целом же исследование проблемы нормативной организации научной речи в рамках стилистики и текстолингвистики сводится К описанию языковых (коммуникативных) фактов, касающихся смысловых и структурнокомпозиционных характеристик разных видов научной прозы (см., напр., работы Е.А. Баженовой, М.Н. Кожиной, М.П. Котюровой, Н.К. Рябцевой). 


\section{Нормы вербального представления аргументативных структур в научно-гуманитарном дискурсе}

В качестве базового принципа, с которым следует согласовывать языковое оформление научно-гуманитарной аргументации, нами выдвигается принцип интерпретируемости ${ }^{3}$ вербальная репрезентация аргументативных структур Аолжна быть такой, чтобы реципиент смог адекватно их идентифицировать, понять, истолковать и реконструировать.

Из принципа интерпретируемости следуют Ава правила: 1) правило смысловой точности и 2) правило наАлежащего употребления аргументативных вербализаторов. Результатом нарушения правиц становятся аргументативные ошибки - неверные, неадекватные аргументативные действия, препятствующие реализации прагматики убеждения.

1. Правимо семантической точности: словесные формулировки в аргументирующем рассужАении Аолжны быть четкими и (по возможности) однозначными. Оптимальное формулирование суждений, максимально точное выражение мыслей - необходимые условия понимания сообщения и во многом залог успешной аргументации ${ }^{4}$. Смысловые погрешности в аргументации, возникающие в результате отклонения от этого правила, имеют прагматическую природу: они препятствуют Аостижению перлокутивного (убежАающего) эффекта 5 .

Зафиксированы следующие разновидности семантико-прагматических Аевиаций.

Семантическая Аеформация - искажение сигнификата вербальной еАиницы вслеАствие употребления ее в несвойственном ей значении. Аеформации подвергается смысл таких частотных Аля научного обихода понятий, как парадигма, коммуникация, таксономия, понятие, термин, концепт, аргументация (причем чаще смысловые искажения допускают русскоязычные авторы). Но больше всего (и в русском, и в белорусском Аискурсах) зафиксировано случаев Аеформированного употребления слова дефиниция: «Нет четких терминологических подходов к самой Аефиниции "политическая система” $\gg\left(\right.$ CA3: 44) ${ }^{6}$; «...считаем целесообразным свести названные выше “множественности” с частицами “мже”, “псевдо”, “квази”, “Аеви”

3 Под принципом здесь понимается конвенциональное фоновое требование к коммуникации.

4 Следует заметить, что традиционно в мингвистическом науковедении понятийная точность рассматривается как «доминанта научного стимя» (см. Кириммова 2015: 69).

5 Обратим внимание, что погрешности, связанные с нарушением требования смысловой точности, явмяются инвариантым элементом практически всех известных классификаций аргументативных ошибок, от античных до современных; это траАиционно находит отражение в учебной митературе по могике и риторике.

6 При ссылках на источники фактического материала здесь и Аалее используются усмовные обозначения (см. Список источников примеров в конце статьи). 
к оАной Аефиниции: “паранаука” или вообще отказаться от него, заменив жесткую и “режущую слух” Аефиницию “паранаука” ... термином “Аругое знание” » (НИК1: 96); «Першапачаткова Аэфініцыя метанімія ўмяшчала ў свой змест моўнае і мітаратуразнаучае тмумачэнне аднаго з тропаў...» (Первоначально дефиниция метонимия вмещала в свое содержание языковое и митературовеАческое объяснение одного из тропов...) (ВБАУ1: 74); «"ВяАучая тэнАэнцыя” - гэта Аэфініцыя, якая ўключае ў сябе і ўмовы фарміравання азначанай асобаснай уласцівасці, і саму ўласцівасць...» («ВеАущая тенАенция - это Аефиниция, которая включает в себя и условия формирования указанного мичностного свойства, и само свойство... ) (ВБАПУЗ: 33).

В приведенных примерах наблюдается смешение смыслов ментальных еАиниц, обозначаемых номинациями дефиниция, термин, понятие. Этот факт вызывает удивление: веАь значения этих слов фиксируются в мексикографических изАаниях. В частности, по Ожегову, дефинииия - 'опредемение, истолкование понятия' (Ожегов 1990: 166); согласно философским словарям и учебникам могики, поА Аефиницией понимается могическая операция, раскрывающая содержание имени посреАством описания существенных признаков предметов, обозначаемых данным именем (см., напр.: Савчук 2003: 20).

Категориахьный сАвиг - объеАинение, сопоставление понятий, относящихся к разнопорядковым категориям. Больше примеров такой погрешности зафиксировано в текстах на русском языке: «В науке есть четкое разграничение этих понятий, в телевизионном тексте это сАелать сложнее...» (НПЖ2: 63); «КАючевое терминопонятие “культурно-речевая компетенция” имеет интегральный (родовой) статус по отношению к состав яющим его основным (базовым) компетенциям» $(\Phi \mathrm{H} 2: 3)$.

Некорректное соотношение понятий отмечается и в белорусскоязычных текстах: «...ў сучасных умовах светапоглядныя ўстаноўкі функцыянуюць не на тэарэтычным узроўні, а на ўзроўні сегментарным, выбарачным i, хутчэй за ўсё, паўсялзённым» (...в современных условиях мировоззренческие установки функционируют не на теоретическом уровне, а на уровне сегментарном, выборочном и, скорее всего, повсеАневном) (ВНАНБ3: 13).

Семантический сбой - алогизм, возникающий в результате подмены понятий и, как слеАствие, неоправАанного смещения преАмета рассужАения в сторону смежной категории. Такая ошибка - частое явление в гуманитарном Аискурсе: «Аиалог, коммуникация - это, несомненно, и Аискуссия, и обсужАение, и взаимоАействие АюАей и иАей ... Ни ОАно из этих наименований не выглядит панацеей от всех беА...» (СА6: 34) - в Аействительности речь идет не о наименованиях, а о понятиях, обозначаемых ими; «Аанное сужАение является кАючевой проблемой всего белорусского спорта, когда перспективный спортсмен в юном возрасте показывает выдающиеся результаты, а при переходе во взрослый спорт не может себя проявить» (СА4: 474) - проблемой, вероятно, явмяется отраженная в сужАении ситуация; «Існуюць асаблівыя жыщщёвыя сітуацыі, якія нельга вырашыць 
працэсамі прадметна-практычнай і пазнавальнай Азейнасці. ААнак іх вырашаюць працэсы перажывання» (Существуют особые жизненные ситуации, которые нельзя решить процессами предметно-практической и познавательной Аеятельности. ОАнако их решают процессы переживания) (ВБАПУ4: 46) - проблемные ситуации можно решить, скорее, не процессами, а Аействиями; «Узаемадзеянне паняццяў культура - дзяржава і дзяржава - культура абумоўлена ix узаемнай патрэбай. Гэта патрэба вызначае ў канчатковым выніку ўсе разнастайныя формы іх кантактаў, накіраванасць і глыбіню ўзаемаўплыву» (Взаимодействие понятий культура - государство и государство - культура обусловлено их взаимной потребностью. Эта потребность определяет в конечном итоге все разнообразные формы их контактов, направценность и глубину взаимовлияния) (ВНАНБ4: 74) - корректно бымо бы говорить о взаимодействии не понятий, а предметов, мыслимых в этих понятиях.

Авусмысленность - использование выражений, Аопускающих неоднозначную трактовку. В некоторых случаях смысл высказывания уточняется послеАующим контекстом: «НереАко поА влиянием обстоятельств или вспыльчивости молодые мюАи совершают поступки, которые в Аальнейшем негативно влияют на жизнь и карьеру. Особую опасность Аля молодых мюАей преАставляет социальное окружение: Арузья, товарищи по школе, сосеАи, знакомые и Ар. Согласно Аанным социологического исследования Института социологии НАН РБ (октябрь 2010 г.), 65,1\% респонАентов имеют знакомых, которые змоупотребцяют спиртными напитками» (CA5: 419).

В Аругих ситуациях Авусмысленность не устраняется контекстуально: «Производство и самореализация творческих мюАей опреАеляют новые походы к потреблению. Потребители престижных бцаг оказывают влияние на качество и стиль жизни инАивиАов, тем самым способствуют укреплению социальной системы...» (СА2: 255); «...калі атрымліваецца незразумелы аАказ, чамавек аАразу шукае імпмікатуру і звычайна яе знаходзіць нават у самых нечаканых месцах. Гэта і становіцца агульнай часткай пытання i алказу, якія ў нашым выпадку і ўяўяюць сцэнарную апазіцыю» (...если получается непонятный ответ, человек сразу ищет импликатуру и обычно ее находит даже в самых неожиданных местах. Это и становится общей частью вопроса и ответа, которые в нашем случае и представляют сценарную оппозицию) (БА: 141).

Референциальная неопределенность - частный случай Авусмысленности - возникает в результате неадекватного употребления разного рода Аейктических среАств: «АюАи разговаривают межАу собой Аискурсами, а не предложениями и тем более не морфемами или фонемами. Это отличает Аискурс от Аругих языковых еАиниц, которые преАставмяют собой научные конструкты, плоды того или иного анациза...» (ВЯ: 3) - вслеАствие непроАуманного использования указательного местоимения остается неясным, какое именно свойство приписывается преАмету мысли - Аискурсу; «Асэнсаванне сябе ў сям’ і хаця і не поўнасцю ўсведамляецца Азіцем, але яно вызначае яго рэакцыі на тое, што адбываецца» (Осмысление себя в семье хотя и не 
полностью осознается ребенком, но оно определяет его реакции на происходящее) (ВБПАУ 1: 42) - причина Авусмысленности - неАифференцированное употребление местоимений 3-го мица.

Искажение реальных могических связей вслеАствие неалекватного синтаксического и пунктуационного оформиения рассуждения. Пример такой ошибки обнаружен в русскоязычном речевом материале: «Язык при всей своей системности от незаполненности ряда макун вовсе не страАает. А возникновение красного словца (Аогоэпистемы) никакой необхоАимостью не мотивировано. Сказал (написал). Услышами (прочитали). Понравияось (повторияи). Вот могоэпистема и возникца» (ФН1: 8). Аогика и прагматика вылеленной фразы проясняется только в результате корректировки ее синтаксиса и пунктуации: Сказал (написал) - усльщшали (прочитали). Понравилось - повторили.

Крайним проявмением семантико-прагматической Аевиантности явмяются рассужАения и тексты, которые не подАаются пониманию и реконструкции, а потому квалифицируются как неинтерпретируемые. В них слова и смысл существуют парамлельно, мибо смысл скрыт настолько глубоко, что Аля его Аешифровки могических и мингвистических знаний недостаточно:

«Совершенствование форм народной хоровой практики взаимосвязано с общеметодологическими основами, расширяющими её Аейственность от художественно-эстетических рамок Ао социокультурного инструментария, средства объединения мюдей, их самосовершенствования на основе богатства национального культурного наслеАия (НИК2: 42); «При невысоком количестве антропонимических еАиниц и суженности круга смысловых векторов многократность употребления этих онимов в текстовом пространстве составмяет 455 раз. <...> ОАнако анациз показывает, что значительное увеличение фреквентативных показателей послеАнего критерия максимально наполняет прагматическим смыслом антропонимные единицы в обозначенных социально-индикационных направлениях и мокализует Аействующих миц в зоне героев второго плана автора-повествователя» (ВБАУ3: 72).

Эти текстовые фрагменты Аемонстрируют явление, названное Г.Г. Хазагеровым «Аисфункцией научного Аискурса». Оно обусловлено «рассогласованностью прагматических установок: самопрезентацией ученого и презентацией новых научных идей» (Хазагеров 2010: 5). Причем одним из наиболее ярких признаков такой Аисфункции, по мнению исследователя, служит «змоупотребление модными научными идиомами» (Хазагеров 2010: 17), что и наблюдается в приведенных выше русскоязычных рассужАениях.

Примеры неинтерпретируемых речевых построений отмечены и в белорусском Аискурсе: «Мэта нашага эмпірычнага Ааследавання - вызначэнне спецыфікі ўспрымання рэкламнага паведамлення студэнтамі сродкамі выяўлення катэгарыяльнай структуры ўспрымання Арукаванай рэкламы, якая 
ўтрыммівае або жаночы, або мужчынскі вобраз» (Цель нашего эмпирического исследования - определение специфики восприятия рекламного сообщения студентами средствами обнаружения категориальной структуры восприятия печатной рекламы, которая содержит ими женский, или мужской образ) (ВБАПУ2: 59); «У цэлым жа за кошт значнага перавышэння памераў памяншэння колькасці кандыдатаў навук наА павелічэннем колькасці дактароў у аналізуемых аб'ектах сістэмы органаў дзяржаўнага кіравання адбылося памяншэнне колькасці даследчыкаў вышэйшай кваліфікацыі - на 1,9\%» (В целом же за счет значительного превышения размеров уменьшения комичества кандидатов наук наА увеличением количества врачей в анализируемых объектах системы органов госуАарственного управления произошло уменьшение количества исследователей высшей квалификации - на 1,9\%) (ВНАНБ2: 11).

В оценке таких текстов сошлемся на мнение специалистов-ортологов: «Аелает научную речь плохой всё, что мешает ее адекватному пониманию, в том числе... стремление к наукообразию в ущерб научности...» (Кирилмова 2015: 84). 3Аесь кажется уместным вспомнить известный афоризм: Кто ясно мыслит - ясно излагает!

2. Правимо компетентного употребления аргументативных вербализаторов: используемые в обосновании языковые индикаторы аргументации должны коррелировать с теми видами аргументативных связей, структур, отношений, которые они обозначают. В противном случае возникает ошибка, которую мы назвали можной навигацией. Суть ее в том, что семантика объективирующих аргументацию языковых среАств не соответствует их прагматической роли. Это приводит к дезориентации воспринимающего субъекта, который «направмяется по Аожному пути».

Охарактеризуем Ава, наиболее распространенных, вида можной навигации.

Употребление фиктивных вербализаторов - использование маркеров аргументации при фактическом отсутствии репрезентируемых ими значений. Особенно часто такая ошибка возникает при употреблении аргументативных кмише, преАназначенных дмя выражения тезиса: рус. таким образом; следовательно; из этого следует/вытекает; мы убедились в том, ито; можно утверждать/сделать вывод, что; ввиду этого; бел. такім чынам; з гэтага вынікае, ито; таму можна зрабіиь вывад, ито; гэта дае падставы сивлрджаць/гаварыць и т.п. Подобные вербализаторы далеко не всегда выполняют свою функцию в Аискурсе. Используясь фиктивно, они выступают как «"Аожные Арузья” интерпретатора»: скрывают могическую ошибку «не следует», которая свидетельствует о несостоятельности аргументации (см.: Савчук 2016: 467).

Употребление псевдовербализаторов зафиксировано и в русско-, и в беморусскоязычной гуманитаристике.

«Так как промышленное производство не акцентируется на преАметах роскоши, нет необходимости в накопмении денег на роскошные товары. 
Таким образом, необходимым условием развития общества является распространение инноваций. Возникновение новых производственных отраслей расширяет слой потребителей. Из этого следует, что с развитием инновационных технологий новые предметы потребления становятся Аоступными в зависимости от потребительских преАпочтений высшего класса. Таким образом, инновационный продукт взаимосвязан с различием бедных и богатых слоев насемения» (СА1: 254). Этот пример примечателен тем, что ни один из включенных в обоснование вербализаторов не реализует свое прагматическое значение.

«Такім чынам, на наш погляА, тэлешоу валодае Аастатковай колькасцю фармальных і змястоўных прымет, якія аАрозніваюць яго аА іншых сённяшніх тэлепрадуктаў, каб выкучыць яго ў якасці асобнага жанру сучаснай тэлежурналістыкі. ПаАагульняючы ўсё сказанае, зробім выснову: тэлешоу гэта праграма, якая характарызуецца пастановачнасцю і відовішчнасцю, наяўнасцю вялікай колькасці камунікатыўных ромяў, асноўная мэта якой забаўленне аўдыторыі або інфармаванне і асвета праз сродкі забаўляльнага тэлевяшчання» (Таким образом, на наш взгляА, телешоу облаАает достаточным количеством формальных и содержательных признаков, которые отличают его от Аругих сегодняшних телепродуктов, чтобы выдемить его в качестве отдельного жанра современной тележурналистики. Подытоживая все сказанное, сделаем вывоА: телешоу - это программа, которая характеризуется постановочностью и зрелищностью, наличием большого количества коммуникативных ролей, основная цель которой - развлечение аудитории или информирование и просвещение через среАства развлекательного темевещания) (ВБАУ2: 85). Насыщенность текста аргументативными клише Аает все основания реципиенту квамифицировать маркируемые ими высказывания как главный тезис аргументации (Телешоу - это особый жанр современной журналистики, который обладает специфическими свойствами). ОАнако Аискурсивный анализ показывает, что такая интерпретация неправомерна: приведенный фрагмент находится в середине текста и восстановленный тезис не имеет прямой корреляции с заголовком («Шоу ў сістэме тәлевізійных жанраў» (Шоу в системе телевизионных жанров). Соответственно, он не согласуется с заданной заголовком интенциональной направленностью статьи (выявмение места шоу в системе телевизионных жанров).

Семантико-прагматический Аиссонанс - погрешность, которая проявмяется в причинно-следственной аргументации. В каузальном обосновании закономерным явмяется дистрибутивный характер использования аргументативных вербализаторов, подчинение их семантических свойств прагматическим (соответственно, положительная оценка слеАствий маркируется лексемами типа способствовать, содействовать, помогать, благоприятствовать и т.п., отрицательная - лексемами преплтствовать, тормозить, затруднять и Ар.). В случае употребления языковых единиц, наделенных «позитивной семантикой», А^я репрезентации негативных 
слеАствий возникает семантико-прагматическая рассогласованность. Такая погрешность чаще наблюдается в русскоязычном Аискурсе (преимущественно в статьях по социологии и психологии): «ИсслеАуются факторы, способствующие воспроизводству и распространению коррупционной практики в современном белорусском обществе» (СА2: 138); «...сейчас в нашем обществе в большей мере востребованы психологические знания, нежели психологическая культура. Это созАает благоприятную почву Аля всевозможного манипулирования мюдьми» (НПЖ1: 17); ОАнако зАесь открывается и перспектива маргинализации научного знания (СА6: 36); «Структурная деформация семьи все-таки крайне нежелательна. Она

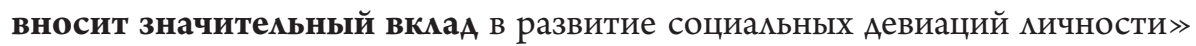
(НПЖ3: 41).

Аналогичные примеры зафиксированы в разнопрофильных текстах на белорусском языке: «Такім чынам, распаўсюджванне апазіцыйнага настрою сярод молаАзі можа стаць значным фактарам у намаганнях апазіцыі Аэстабікізаваць сітуацыю ў рэспубліцы. Разам з тым наяўнасць бюракратычных падыходаў улаА да вырашэння шматлікіх праблем ... садзейнічае Аалейшаму распаўсюАжванню радыкальна-апазіцыйнага настрою сярод значнай часткі моладзі» (Таким образом, распространение оппозиционного настроения среди молодежи может стать значительным фактором в усилиях оппозиции Аестабилизировать ситуацию в республике. Вместе с тем наличие бюрократических подходов властей к решению многих проблем... способствует Аальнейшему распространению радикально-оппозиционного настроения среАи значительной части молодежи) (БА: 121); «Аля сучаснага гледача неігравы фільм з'яуцяецца сінонімам усяго сумнага і стомнага, чаму паспрыяла зАранцвелая клішыраваная форма многіх карцін» (Аля современного зрителя неигровой фильм является синонимом всего скучного и утомительного, чему поспособствовала одеревеневшая клишированная форма многих картин) (ВНАНБ1: 70); «Камічны эффект Аасягаецца пры Аапамозе парушэння максім Грайса» (Комический эффект Аостигается с помощью нарушения максим Грайса) (БА: 141).

Во всех этих аргументирующих рассужАениях негативная оценка слеАствий Аиссонирует с их «позитивным» вербальным преАставлением (позитивная семантика вербализаторов подтверждается словарными толкованиями: Способствовать - 1. Оказывать помощь, содействовать. 2. Быть причиной, помогать возникновению, развитию чего-н. (Ожегов 1990: 756); Благоприятствовать - Способствовать, помогая в чем-н. (Ожегов 1990: 55). ЗАравый смысл в Аанном случае представляется надежным основанием Аля утвержАения: помогать плохому, негативному противоестественно.) Заданная аргументативной схемой когнитивная установка на позитивное слеАствие не оправдывается, что искажает восприятие аргументации.

Ошибки, совершаемые аргументатором на вербально-концептуальном уровне, ощущаются реципиентом как Авижение с препятствиями: понимание аргументации требует напряжения - Аополнительных 
интемлектуальных, эмоциональных и временных затрат, что не способствует эффективности коммуникации.

\section{Заключение}

Выбор языковых среАств, вербализующих аргументацию, входит в зону персонамьной ответственности ученого. Учитывая, что письменный Аискурс характеризуется продуманностью и подготовленностью, а научная статья - продукт Алительной аналитической работы исследователя, погрешности, связанные с неадекватной вербализацией научного обоснования, трудно оправдать. Их профилактика - формирование аргументативной компетенции, а также внимательное и ответственное отношение гуманитариев к презентации результатов научного поиска.

В этом плане преАставляется уместным апемлировать к мнению специалиста по эпистемологии Н.С. Автономовой. Размышияя о философском языке, она замечает: «...Сейчас, наверное, труднее, чем когАа-либо раньше, быть умным, но мегче им казаться: нет не только заданной системы связей межАу понятиями, нет и языка как системы, есть отдельные словечки, которые стало модно объеАинять в цоскутные одеяла» (Автономова 1999: 17). Эти мысли, высказанные Авадцать мет назаА, сегодня не только не потеряли актуальности, но умножили ее многократно. Не менее важен вывоА исследовательницы об ответственности чценов научного сообщества за свои слова и одновременно ответственности «переА словом и понятием» (Там же).

Злободневным явмяется еще одно высказывание Н.С. Автономовой: «научиться читать мысли много сложнее, чем научиться читать буквы» (Автономова 1999: 22). Развивая эту идею, надо признать, что научиться писать мысли (а значит, создавать смыслы) гораздо сложнее, чем научиться писать слова и преАложения. В этом контексте особую значимость приобретает саморефлексия исслеАователей-гуманитариев как путь к профессиональной илентичности.

Как показал сравнительный анализ, некорректное языковое поведение Аопускается и русско-, и белорусскоязычными авторами. Разиичается мишь частотность тех или иных аргументативных ошибок.

Проведенное исследование подтвердило эффективность конвергентного подхода к изучению аргументативного Аискурса: необходимым усмовием качественного анациза и адекватной оценки научно-гуманитарной аргументации явмяется объединение методов Аингвопрагматики и могики.

Разработанная нормативная концепция, как преАставляется, может послужить методологической базой Аля Аальнейших интеграцьных исслеАований аргументации, а также практическим руководством по формированию аргументативной компетенции. 


\section{Литература}

Автономова, Н.С. (1999). Заметки о фикософском языке: традиции, проблемы, перспективы. Bопросы философии. № 1. С. 13-28.

Брутян, Г.А. (1992). Очерк теории аргументаиии. Ереван: ИзА-во АН Армении. 303 с. Аемьянков, В.3. (1982). Конвенции, правила и стратегии общения (интерпретирующий подхоА к аргументации). Известия АН СССР. Сер. ^ит. и яз. Т. 41. С. 327-337.

Еемерен, Ф.Х. ван, Гроотендорст, Р. (1992). Аргументация, коммуникация и ошибки. Пер. с англ. Санкт-Петербург: «Васильевский остров». 208 с.

Киримлова, И.А. (2015). Сфера науки. В: Хорошал речь: коммект. моногр. Сиротинина, О.Б. и Ар. / поА реА. М.А. Кормилицыной и О.Б. Сиротининой. ИзА. 3-е, стер. Москва: URSS: Аиброком. С. 69-84.

Матвеева, Т.В. (2000). Об ортологии текста. В: Культурно-речевая ситуация в современной России: сб. статей / поА реА. Н.А. Купиной. Екатеринбург: ИзА-во Урах. ун-та. С. 21-29.

Ожегов, С.И. (1990). Словарь русского языка: 70000 слов / поА реА. Н.Ю. Шведовой. 22-е изА., стер. Москва: Рус. яз. 991 с.

Савчук, Т. (2016). Вербализация аргументативных структур в научном гуманитарном Аискурсе. В: Русистика и современность. 18-я Междунар. науч. конф.: сб. науч. работ. Рига: Балтийская международная академия. С. 461-468.

Савчук, Т.Н. (2003). Һогика. В 3 ч. Ч. 1. Имена и высказывания. Минск: ИзА-во МИУ. $45 \mathrm{c}$.

Хазагеров, Г.Г. (2010). Обессмысливание научного дискурса как объективный процесс. Социологический журнал. № 2. С. 5-21.

Чернявская, В.Е. (2011). Нормативное и девиантное в научной коммуникации.

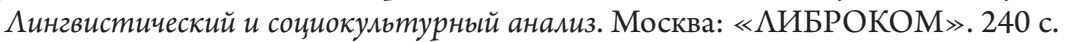

Eemeren, F.H. van, Garssen, B., Krabbe, E. et al. (2014). Argumentation theory. In: Handbook of argumentation theory. Dordrecht [etc.]. Pp. 1-50.

Eemeren, F.H. van (2001). Fallacies. In: Crucial concepts in argumentation theory / ed. by F.H. van Eemeren. Amsterdam: Amsterdam University Press. Pp. 135-164.

Grice, H.P. (1975). Logic and conversation. In: Syntax and Semantics. Vol. 3: Speech Acts. New York: Academic Press. Pp. 41-58.

Leech, G.N. (1983). Principles of pragmatics. London, New York: Longman. 250 p.

\section{Источники примеров}

БА - Казмякоў, У. (2003). Азеткі ці марыянеткі? Беларуская думка. № 8. С. 116-121. БА - Фамічова, Н.В. (2011). Моўныя сродкі выражэння камічнага ў беларускім гумарыстычным фальклоры. Беларускал Аінгвістыка, выпуск 67. С. 144-145.

ВБПАУ1 - Грыцкова, К.В. (2005). Спецыфіка сямейнага ўзаемаАзеяння ў паАлеткавым узросце. Весиі БАПУ. Серыя 1, Педагогіка. Псіхалогія. Філалогія. № 1 (43). С. 40-44.

ВБАПУ 2 - Істамянок, С.С. (2005). Успрыманне Арукаванай рэкламы стуАэнтамі. Весиі БАПУ. Серыя 1, Педагогіка. Псіхалогія. Філалогія. № 2 (44). С. 59-61.

ВБАПУЗ - Петрашкевіч, Н.У. (2006). Роля тыпалагічных Аэтэрмінант у дынаміцы індывідуальна-асобасных уласцівасцей. Весці БАПУ. Серыя 1, Педагогіка. Псіхалогіл. Філалогія. № 1. С. 33-37.

ВБАПУ4 - Мнішкур, К.С. (2005). Псіхалагічная абарона - форма пазітыўнага ўплыву на эмацыянальны стан асобы. Весиі БАПУ. Серыя 1, Педагогіка. Псіхалогія. Філалогія. № 2 (44). C. 46-48. 
ВБАУ1 - Горбач, В.А. (2008). Метанімія як мінгвістычны інструмент дыскурснага аналізу СМІ. Веснік БАУ. Серыл 4, Філалогіл. Журналістыка. Педагогіка. № 2. C. 73-76.

ВБАУ2 - Кузьмінава, А.Ю. (2014). Шоу ў сістэме тэлевізійных жанраў. Веснік БАУ. Серыл 4, Філалогія. Журналістыка. Педагогіка. № 1. С. 84-87.

ВБАУЗ - Шеверинова, О.В. (2015). Номинационные ряды мужских персонажей в антропонимиконе В.П. Астафьева: социопрагматический аспект. Веснік БАУ. Серыя 4, Філалогія. Журналістыка. Педагогіка. № 2. С. 69-73.

ВНАНБ1 - Аашук, В.В. (2005). Паняцце мастацкага стылю ў Аакументальным кіно (на матэрыяле беларускіх неігравых фільмаў). Весиі НАН Беларусі. Серыя гуманітарных навук. № 3. С. 70-76.

ВНАНБ2 - Азімітрук, П.П. (2002). КаАравая сітуацыя ў навуцы Рэспублікі Беларусь. Весиі НАН Беларусі. Серыл гуманітарных навук. № 1. С. 5-13.

ВНАНБ3 - Мыслівец, М.А. (2004). Сацыяльнае самавызначэнне і каштоўнасныя арыентацыі беларускіх студэнтаў. Весијі НАН Беларусі. Серыя гуманітарных навук. № 4. C. 11-16.

ВНАНБ4 - Скараходаў, У.П. (2003). Узаемадзеянне культуры і дзяржавы. Весиі НАН Беларусі. Серыл гуманітарных навук. № 2. С. 74-79.

ВЯ - Кибрик, А.А. (2009). Модус, жанр и Аругие параметры классификации дискурсов. Вопросы языкознания. № 2. С. 3-21.

НИК1 - Калинина, Г.Н. (2012). Паранаука - маргинальное знание или... спор за науку? (в чьи паруса дует ветер века?). Наука. Искусство. Культура, выпуск 1. C. $93-102$.

НИК2 - Сараева, А.П. (2012). Музыкальный фольклор в аспекте его социальнорегумятивного содержания. Наука. Искусство. Культура, выпуск 1. С. 8-17.

НПЖ1 - Аубровина, И.В. (2007). Психологическая культура и образование. Национальный психологический журнал. № 2. С. 16-20.

НПЖ2 - Мамыгина, А.Е. (2010). Темевизионный анонс: информирование ими манипукирование. Национальный психологический журнал. № 2 (4). С. 60-63.

НПЖ3 - Реан, А.А. (2007). Семьи риска. Аети. Общество. Национальный психологический журнал. № 2. С. 40-43.

СА1 - Баханов, А.Г. (2013). Авойственная природа престижного потребления: социологический анализ. Социологический альманах, выпуск 4. С. 251-257.

СА2 - Бубнов, Ю.М. (2011). Коррупция как социальная болезнь. Сочиологический альманах, выпуск 2. С. 138-149.

САЗ - Котмяров, И.В. (2011). Политическая система Бекаруси: теоретическое регулирование и социологическое осмысление. Социологический альманах, выпуск 2. С. 41-53.

СА4 - Синиченко, Р.П. (2013). Хоккей как стиль жизни и зрелище: социологический анализ. Социологический альманах, выпуск 4. С. 469-476.

CA5 - Тарасов, В.С. (2013). Профикактика потребления спиртных напитков и формирование здорового образа жизни. Социологический альманах, выпуск 4. C. 417-425.

СА6 - Федотова, В.Г. (2011). Коммуникация и диалог в науке и за ее предемами. Социологический альманах, выпуск 2. С. 33-40.

ФН1 - Бурвикова, Н.А., Костомаров, В.Г. (2008). Аогоэпистемическая составляющая современного языкового вкуса. Филологические науки. № 2. С. 3-11.

$Ф Н 2$ - Сковородников, А.П., Копнина, Г.А. (2009). О культурно-речевой компетенции студента высшего учебного заведения. Филологические науки. № 3. С. 3-14. 


\section{Semantiski pragmatiskas kḷūdas zinātniskā argumentācijā: krievu un baltkrievu humanitāro zinātṇu teksti}

Rakstā aplūkots krievu un baltkrievu zinātniskais un humanitārais diskurss. Raksta autore sistematizē semantiski pragmatiskas kḷūdas, kuru pamatā ir neadekvāts valodas lìdzekḷu izmantojums un interpretācijas principa neievērošana. Autore raksturo tādus deviācijas veidus kā semantiskas un kategoriju deformācijas, neskaidras references, semantiski pragmatiska disonanse u. c., atklājot šo kḷūdu rašanās mehānismus.

\section{Semantic-Pragmatic Fallacies in Scientific Argumentation (on the material of Russian and Belarusian texts inn humanities)}

The article presents the result of the logical-linguistic analysis of Russian-language and Belarusian-language scientific discourse in humanities. Semantic-pragmatic fallacies, the source of which is the inadequate use of linguistic means because of violation of the principle of interpretability, are systematized. Different kinds of deviations are described such as semantic deformation, categorical shift, semantic failure, referential uncertainty, semantic-pragmatic dissonance etc. The mechanisms of occurrence of these fallacies are identified; their semantic-pragmatic nature is substantiated. 
DOI: http://doi.org/10.22364/ruslat.glp.16

\section{Алеся Шевцова}

\section{Белорусский рекламный дискурс сквозь призму глобализационных процессов: сопоставительный аспект ${ }^{1}$}

Манифестацией глобализационных тенденций в белорусскоязычном рекламном Аискурсе в целом явцяется его проблемно-тематическая и коммуникативно-лингвистическая близость с англо- и русскоязычным Аискурсом рекламы. Номенклатура коммуникативных стратегий и тактик на материале трех исследуемых языков, а также способы их языковой реализации примерно аналогичны (стратегии самопрезентации, аргументации, убеждения, установления контакта и Ар.). Кроме того, языковая глобализация белорусскоязычного рекламного Аискурса поАтвержАается общими тенАенциями к широкому использованию англицизмов, Аемократизации языка и экономии языковых средств.

Ключевые слова: коммуникативная стратегия, коммуникативная тактика, языковая глобализация, Аискурс коммерческой рекламы, Аискурс социальной рекламы

Распространение рекламного Аискурса само по себе явмяется проявмением расширения глобализационных процессов в различных странах и мингвокультурах. ОАнако помимо неугасающей популярности рекламного Аискурса как инструмента воздействия на сознание общества, определенный интерес преАставцяет его наполнение.

Тексты среАств массовой информации преАставцяют собой именно Аискурс, они всегда Аинамичны и современны, они воспринимаются участниками коммуникации в контексте происходящих событий. В основе коммуникативного (ситуативного) направления в исследовании Аискурса межит илея о том, что «при анализе Аискурса следует учитывать поле прагмалингвистического исследования (социальные, психологические и культурно значимые условия и обстоятельства общения)» (Карасик 1998: 190). В рамках коммуникативной мингвистики Аискурс преАставцяется как «речевое взаимодействие участников коммуникации, в процессе которого

1 Исследование выполнено в рамках НИР «Тенденщии развития и функционирование белорусскоязычного медиадискурса в условиях глобализации и межкультурного Аиалога» (№ госрегистрации 20161437) поАпрограммы «Беморусский язык и митература» государственной программы научных исскедований «Экономика и гуманитарное развитие беморусского общества» на 2016-2020 гг. 
первостепенную роль приобретают его психологические, социально-ролевые, социокультурные, когнитивные и коммуникативные аспекты» (Шевцова 2016: 8).

По определению Т.А. ван Аейка, «Аискурс - это речевой поток, язык в его постоянном Авижении, вбирающий в себя все многообразие исторической эпохи, индивидуальных и социальных особенностей как коммуниканта, так и коммуникативной ситуации, в которой происходит общение. В Аискурсе отражаются менталитет и культура как национальная, всеобщая, так и индивидуальная, частная» (Аейк 1989: 13). Таким образом, мы будем опираться на коммуникативную трактовку Аискурса. ВслеА за Н.А. Арутюновой и В.В. Красных, поА Аискурсом в настоящем исследовании понимается «вербализованная речемыслительная деятельность, включающая в себя не только собственно мингвистические, но и экстралингвистические (прагматические, социокультурные, психологические и Ар.) компоненты», «текст, взятый в событийном аспекте» (Арутюнова 1990: 137; Красных 1998: 190). Из вышеприведенных умозаключений слеАует вывоА о том, что рекламные тексты следует рассматривать с позиций Аискурсивного анамиза в контексте глобализационных процессов с акцентом на имеющиеся этнокультурные особенности, свойственные той или иной мингвокультуре.

При этом анализ рекламного Аискурса встраивается в более общую парадигму исследований меАийного, или масс-медийного, Аискурса. Рекламный Аискурс как разновиАность медийного Аискурса, по свидетельству Т.Г. Аобросклонской, может выступать кумьтурообразующим фактором в жизни современных мюдей (Аобросклонская 2005: 28). Если обобщить результаты исслеАований медийного Аискурса (Аобросклонская 2008; КарАумян 2011; Кобрик 2008; Нестерова 2009; Солганик 2005 и Ар.), то можно выделить такие его наиболее характерные черты, как а) Аинамичность языковой нормы; б) снижение нормы устного говорения; в) тематическую неисчерпаемость; г) разнообразие мексики и активное использование в речи иноязычных вкраплений, интертекстуальных включений, игры слов на основе их многозначности и сочетаемости; А) активизацию механизмов свободного построения Аискурса и отхоА от схематичности при изложении фактов; е) изменение синтаксического построения речи (Шевцова 2016: 12). Вместе с тем, по мнению Т.Г. Аобросклонской, наиболее важным в изучении языка СМИ явмяется анализ «лингвостилистических и меАийных особенностей конкретных подъязыков массовой информации - языка прессы, языка радио, языка темевидения, особенностей речеупотребцения в Интернете» (Аобросклонская 2008: 21). К числу подобных «подъязыков массовой информации» можно отнести и язык рекламы.

При анализе мингвистического наполнения рекламного Аискурса мы учитываем коммуникативно-прагматическую сторону. По мнению М.А. Банщиковой, особенность Аанного вида Аискурса заключается в том, что, с оАной стороны, буАучи ориентированной на побужАение аАресата к Аействию и являясь императивным Аискурсом, реклама избегает прямого 
выражения побуждения. Это объясняется тем, что АюАи настороженно относятся к коммуникации посредством императивных конструкций. С Аругой стороны, реклама не подлежит внимательному анализирующему прочтению и воспринимается в еАином информационном потоке, как правило, без четкой установки на детальный анализ, поскольку аАресат не располагает Аостаточным количеством времени, чтобы рассмотреть Аостоинства и неАостатки объекта (Банщикова 2002: 198). Аанные особенности и опре-

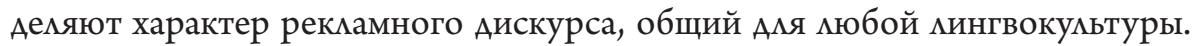

Таким образом, резюмируя имеющиеся работы по рассматриваемой проблеме, приходим к вывоАу о том, что рекламный Аискурс - оАин из видов императивного Аискурса, который служит коммерческим целям, не подлежит внимательному прочтению и отражает ценности современного общества. Эффективность рекламного сообщения Аостигается при помощи соотнесения вербальных и невербальных приемов с целями и заАачами коммуникации, коммуникативной интенцией и перспективой, системной спаянности элементов коммуникативной стратегии, практической цемесообразности отдельных тактических ходов.

Материалом настоящего исследования послужили 60 рекламных роликов на белорусском языке и столько же на русском и английском языках. При этом 50\% материала составили ролики коммерческой рекламы и $50 \%$ социальной. Обратимся вначаме к анахизу коммерческой рекламы.

\section{Коммуникативно-прагматическая сторона коммерческой рекламы и ее лингвистическое наполнение}

СреАи стратегий и тактик коммуникативно-прагматического возАействия коммерческой рекламы в качестве магистральных можно выдекить стратегии самопрезентации, аргументации, апеммяции к эмоциям, тактику информирования, тактику расположения клиента и тактику вовлечения в Аиалог. ОАнако Аоминирующую роль в Аискурсе коммерческой рекламы играет коммуникативная стратегия убеждения, которая охватывает наибольший спектр тактик, среАи которых отАельно выделяется тактика побужАения к Аействию. Помимо императивных конструкций, реализующих выше названную тактику, свойственных рекламе на всех трех отобранных языках: "Live in Levi's" (Живи в Levi's); “Look at your man” (Посмотри на своего мужчину); “Use Finish Dishwasher Cleaner” (Используйте среаство Аля посудомоечных машин Finish); «Попробуй удивительную нежность»; «Откройте чарующий мир французских роз»; «ЗавеАи освежающую при-

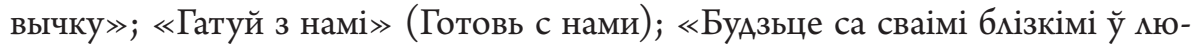
бым кутку краіны» (Будьте со своими близкими в Аюбом уголке страны); в белорусскоязычной коммерческой рекламе аАресата зачастую побужАают к Аействию путем использования повторов, парамлельных конструкций. Например: «Новы час, новыя магчымасці»; «новая якасць і сучасныя тэхналогіi »; «Крыніца - наша піва» (Новое время, новые возможности; новое качество и современные технологии; Криница - наше пиво). Прилагательным 
новый подчеркивается инновационность, новизна и уникацьность именно этого товара. Следовательно, повтор информации, которую производитель считает кАючевой, подсознательно возАействует на потребителя. Стратегия убеждения также вербализуется посреАством тактики информирования примерно в равной степени в трех мингвокультурах. Языковым инаикатором актуализации данной тактики явцяются числительные, отражающие статистические Аанные, имена собственные, имена существительные и глаголы, участвующие в изложении конкретных фактов Аействительности, цитаты: “96\% of women agree" (96\% женщин согласны); «Клетки получают недостающее питание, кожа сама вырабатывает комлаген, эластин и гиауронаты»; «Его отбеливающие компоненты и частицы гиАрофреш приАают вашей умыбке трехмерную белизну и до 6 раз больше свежести»; «СпраАвек гаварылі беларусы: “Журавінавы квас - у кожным кубку моц неверагодная, і з квасам тым кожны бадзеры будзе”. Вясну сустракалі так - хатні журавінавы квас» (Испокон веков говорили белорусы: «Клюквенный квас - в кажАой кружке сила невероятная, и с квасом этим кажАый бодрым будет» Весну встречали так - Аомашним клюквенным квасом).

Стратегия аргументации тесно связана со стратегией убежАения и способствует построению доверительных отношений с потребителем. Цель аргументов - воздействовать на рациональную сферу реципиента. В Аискурсе коммерческой рекламы на трех языках реализации стратегии аргументации способствует тактика апемляции к авторитету. Присутствие в рекламном ролике известной аудитории мичности (популярный актер, певец, шоумен), выступающей в качестве транслятора рекламного сообщения и преАположительно достоверно излагающей аргументы в пользу товара, повышает уровень Аоверия к рекламному сообщению. В роликах мы встречаем таких известных персон, как Ирина Шейк, Кэти Перри, Вера Брежнева, Анна Ковахьчук, Ингеборга Аапкунайте, Елена Спиридович и Ар. АуАитория охотней верит известным мюАям и покупает рекламируемый товар. Приведем белорусскоязычный пример с участием Алины Тамай, известной спортсменки национальной сборной Республики Беларусь по мегкой атметике: «Азе мне патрэбны інтэрнэт? Аы паўсюль. Я ніколі не сяджу на месцы. 3’язджаю, вяртаюся, зноў з'язАжаю. Але ўвесь час застаюся ў цэнтры паАзей. Мае бмізкія ... Без іх я не магу, хачу іх бачыць кожны Азень, нават калі яны вельмі далека. Куды 6 не завяло мяне жыцце, мне важна не згубіць Аарогу Аа сваей мэты. Без інтэрнэта жыцце нібыта спыняецца, а я не хачу стаяць на месцы. Я хачу бегчы, бегчы ўвесь час. Будзьце са сваімі блізкімі ў мюбым кутку краіны. Якасная сувязь і хуткасны інтэрнэт паўсюль, Азе вы» (VELCOM 'ГАе мне нужен интернет? Аа везАе. Я никогАа не сижу на месте. Уезжаю, возвращаюсь, снова уезжаю. Но все время остаюсь в центре событий. Мои близкие ... Без них я не могу, хочу их видеть кажАый Аень, Ааже когда очень Аалеко. Куда бы не забросима меня жизнь, Аля меня важно не потерять пути к своей цели. Без интернета жизнь будто останавливается, а я не хочу стоять на месте. Я хочу бежать, бежать все время. Будьте 


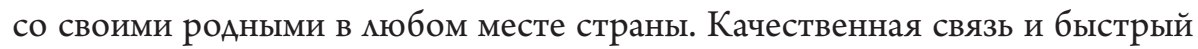
интернет везде, где вы. VELCOM').

Стратегия самопрезентации является Аостаточно типичной Аһя коммерческой рекламы. Ее суть заключается в преАставлении рекламируемой продукции в наиболее выгодном свете. В этой связи употребление степеней сравнения прилагательных, ярких эпитетов и метафор способствует реализации данной стратегии. Настоящая стратегия вербализуется с помощью Авух основных тактик: тактики выделения товара и тактики расположения к себе.

Тактика выдемения товара актуализируется путем употребления сравнительной и превосходной степеней сравнения прилагательных, которые можно отнести к морфологическим среАствам, встречающимся в текстах коммерческой англоязычной, русскоязычной и белорусскоязычной рекламы: "the most effective conditioner" (самый эффективный кондиционер), "the greatest skin care" (наилучший уход за кожей), "stronger" (сильнее), "shinier” (более сияющий), “deeper” (глубже), самый яркий, самый попумярный, «больш выразны» (более выразительный) и Ар. За счет степеней сравнения рекламируемый товар можно выделить среАи Аругих своим превосходством, уникальностью и качеством. В этом и заключается коммуникативная тактика коммерческой рекламы: выделить товар среди конкурентов и убедить в том, что он мучший.

В основе тактики расположения к себе лежит предпочтение со стороны аАресанта выразительных среАств речи с положительной коннотацией, позитивно окрашенной мексики. Анализируя мексические среАства рекламных роликов на трех языках, чаще всего мы встречаемся с эпитетами (зафиксирована 71 единица): “unpredictable hair” (непредсказуемые волосы), “intense color” (интенсивный цвет), "luxurious oils” (роскошные масла), "extraordinary high-impact color” (необычайно впечатмяющий цвет), «шелковый шоколаА», «шелковое удовольствие», «насыщенный вкус», «нежная кофейная пена», «яркий фруктовый вкус», «неожиланно нежное сочетание», «маленькие секреты», «освежающая привычка», «илеальный ухоА», «свежие илеи», «модное оружие», «зеркальный блеск», «обволакивающая текстура», «изысканный шоколаА», «кристальная чистота», «беларускі характар» (белорусский характер), «захапияльная глыбіня» (захватывающая глубина) и Ар. Использование эпитетов способствуют Аостижению определенного эффекта: усиливается выразительность, информативность, подчеркиваются качества рекламируемой продукции. Эпитеты создают образность речи, что упрощает понимание и улучшает восприятие информации, заложенной в рекламе. Оригинальность текста повышается за счет употребления эпитетов, а вместе с оригинацьностью и интенсивность возАействия на ауАиторию.

В ходе исследования отмечалось активное употребление метафор (всего 45 еАиниц) как в англоязычной, так и в русскоязычной и белорусскоязычной рекламе: "the fortune is in your hand" (судьба в твоих руках), "lips feel 
softer" (губы чувствуют мягкость), "make friends with your hair" (подружись со своими волосами), «кожа омолодилась», «фрукты раскрывают аромат», «попробуйте нежность», «откройте мир роз», «Сатау пленяет кажАой чертой», «экстракты мимона Аобавили силы», «посуда сияет», «у кожным кубку моц» (в каждой кружке сила), «адчыняюць крыніцы неверагоАных магчымасцяў» (открывают источники невероятных возможностей), «тэхналогіi змянілі мір» (технологии изменили мир), «жыцце спыняецца» (жизнь останавливается). Метафора явцяется материалом Аця иммюстрации основной мысли, идеи. Особенность памяти мюбого потребителя заключается в том, что информация в форме метафоры запоминается быстрее, чем при обычном рациональном изложении. Воздействие на подсознание и память аАресата при помощи троп побужАает к покупке товара.

Стратегия установмения контакта и реализущая ее тактика вовмечения в Аиалог органично вписываются в коммерческий рекламный Аискурс с точки зрения построения Аоверительных отношений с потребитемем. При этом реципиент мыслится как активный участник рекламного Аискурса. Аанное умозакмючение подтвержАается наличием многочисленных вопросительных преАложений, аАресованных потенциальным потребителям: "Are you and your dry hair not getting along?" (Вы не мадите со своими волосами?); “How do your lashes grow?” (Как растут ваши ресницы?); "Does your shampoo wash out your colour?” (Ваш шампунь вымывает цвет?); «Хотите узнать правау о гемях Амя Ауша?»; «В чем ее секрет?» Помимо вопросительных преАложений в рекламных роликах на трех языках используются ситуации «живого» Аиалога. Такие Аиалоги, обыгрывающие ситуации использования товара, вовлекают потребителя в реальные условия. Например:

- Чызбургер гэты не трэба табе (Чизбургер этот не нужен тебе).

- Навошта мне гэты чызбургер? (Зачем мне этот чизбургер?)

- Бульбу Йодзе жадаешь аААаць (Картошку Йоде хочешь отАать).

- Так, забірай (Аа, забирай).

- Гэты напітак не хочаш ты (Этот напиток не хочешь ты).

- Не, Pepsi я уссе-такі хачу (Нет, Pepsi я все-таки хочу).

- Не хочаш (Не хочешь).

- Хачу! (Хочу!)

- Пі Pepsi, збяры пятнаццаць зорак на накрыўках і атрымай суперфутболку (Пей Рерsi, собери пятнадцать звезА на крышках и помучи суперфутболку).

Суть стратегии апемяяции к эмоциям закмючается в возАействии на чувства и эмоции потенциального потребителя. Аля этого используются восклицательные преАложения, эмотивные конструкции, выразительные средства речи. В рекламном дискурсе на трех языках отмечается активное апемлирование к чувству наслаждения, мюбви, восхищения и Аругим положительным чувствам и эмоциям. Например: «ВеАь в оАной конфетке 
Toffffee есть 4 причины дмя умыбок всей семьи: чашечка из мягкой карамели, цельный орех, кремовая нуга, а еще восхитительный шоколад!»; «Вельмі падыходзіць зранку, разам з кавай, паА смятанку. Аладкі ГаспаАар смачна есці, прыемна гатаваць» (Очень подходит с утра, вместе с кофе, поА сметанку. Оладьи ГаспаАар - вкусно кушать, приятно готовить). Восклицательные, экспрессивно насыщенные преАложения помогают усилить выразительность и белее эффективно воздействовать на аудиторию: «Цвет великолепный!»; «Столько радости с Toffifee!»; «Кажуць беларусы: “Журавінавы смак у хаце - зімой галоўнае багацце!” (Говорят белорусы: «КАюквенный вкус в доме - зимой главное богатство»).

\section{Коммуникативно-прагматическая сторона социальной рекламы и способы ее вербализации}

Обращаясь к результатам анализа социальной рекламы и ее сопоставмения с коммерческой рекламой на белорусском, русском и английском языках, необходимо отметить как общие, так и специфические тенденции. В целом социальная реклама несет иную прагматическую направленность, что обусловило различия в инструментарии коммуникативно-прагматических стратегий и тактик и, соответственно, определияо ряА особых способов вербализации отдельных фрагментов в Аискурсе социальной рекламы.

Общей чертой социальной рекламы на трех языках является то, что во всех случаях Аискурс рекламы базируется на трех основных стратегиях стратегии убежАения, стратегии установмения контакта и стратегии антисамопрезентации. Из вышеперечисленных стратегий мишь послеАняя маркирует Аискурс социальной рекламы как отличный от коммерческого Аискурса. Аанную стратегию чаще всего реализует тактика устрашения, которая весьма частотна в англо- и русскоязычной рекламе. В белорусскоязычной рекламе тактика устрашения не находит широкого распространения, однако стратегия антисамопрезентации успешно актуализируется путем употребления мексики с негативной семантикой. Например: «Рано или поздно наши родители постареют. Но он все равно умыбнется, но будет уже позАно. Родители. Берегите их. Можно просто не успеть ... »; «КАімат планеты цяплее, але гэта небяспечна. Гмеба пераўтвараецца ў пустэчы, нашы мясы таксама тяжка пераносяць змены. А ў парках стала шмат кмящоў. ААнак кожны чалавек можа змяніць звычкі на экалагічныя. Берагчы мес і не Аапускаць пажараў, выбіраць мясцовыя сезонныя прадукты, апрацоўваць зямлю без хімікатаў» (КАимат планеты теплеет, но это небезопасно. Земля превращается в пустыню, наши меса тоже тяжело переносят перемены. А в парках стало много кмещей. ОАнако кажАый человек может поменять свои привычки на экологичные. Беречь мес и не допускать пожаров, выбирать местные сезонные продукты, обрабатывать земмю без химикатов).

Среди всех коммуникативных тактик, самой распространенной на материале трех исследуемых языков преАставляется тактика побужАения к Аействию, которая реализует стратегию убеждения и вербализуется $\mathrm{c}$ 
помощью императивных конструкций. Например: «Хорошо, когАа ремень безопасности пристегнут. Только в этом случае он спасает жизнь и зАоровье в АТП. Пристегнитесь или пристегнут вас»; «Зачыняйце Азверы змодзей можа быць побач!» (Закрывайте Аверь - преступник может быть рядом!); "Now you know how it feels to get motor neurone disease. Help us fight back" (Теперь вы знаете, что значит иметь заболевание Авигательных нервов. Помогите нам Аать ему отпор). В рамках стратегии убежАения также применяется тактика информирования, направленная на просвещение аудитории по тому ики иному вопросу и мотивирования к построению определенной модели социального повеАения: «В 2011 году при пожарах в Москве погибло 194 человека, более трети из них не удалось спасти из-за неправильно припаркованных машин»; «Больш за мільён дацяраў Аля 129 цяжкахворых Азяцей мы сабралі у 2013 годзе. Мы - гэта вы. Напачатку мы атрымлівалі 16 ахвяраванняў штодня, цяпер 287» (Более мимлиона Аолмаров Аля 129 тяжелобольных детей мы собрали в 2013 году. Мы - это вы. Вначале мы получали 16 пожертвований ежедневно, сейчас 287). В целом, социальный рекламный Аискурс на трех языках использует схожие коммуникативно-прагматические методы воздействия на аудиторию.

\section{Актуализация глобализационных тенденций в белорусскоязычном рекламном дискурсе}

Манифестацией глобализационных тенденций в белорусскоязычном рекламном Аискурсе в целом является его проблемно-тематическая и коммуникативно-лингвистическая близость с англо- и русскоязычным Аискурсом рекламы. Номенклатура коммуникативных стратегий и тактик на материале трех исследуемых языков, а также способы их языковой реализации примерно аналогичны. Основная специфика состоит в частотности употребления тех или иных языковых средств. Исходя из полученных данных, можно сАелать вывод о том, что белорусский рекламный Аискурс органично влился в общий поток рекламного Аискурса и принял все его типичные черты.

ОАнако на фоне Авух Аругих языков белорусскоязычный коммерческий рекламный Аискурс более полно вербализует стратегию самопрезентации, прибегая к употреблению многочисленных метафор, эпитетов и Аругих экспрессивных стилистических среАств: «ВеАае толька багіня вясны, Азе шукаць цудоўны скарб вяснянкі - журавіны, што праспалі зіму у снезе, збераглі карысць і маюць смак назвычайны» (Знает только богиня весны, гАе искать волшебный клаА весны - клюкву, которая проспала зиму в снегу, сохранила пользу и имеет вкус удивительный); «Вы ніколі не бачылі больш чароўных колераў, больш выразнай яркасці, больш захаплямьнай глыбіні і Аэталізацыі» (Вы никогда не видели более завораживающих цветов, бомее выразительной яркости, более захватывающей глубины и детализации). Также, следует обратить внимание на то, что не во всех случаях можно однозначно определить конкретный языковой инструмент, который реализует 
ту ими иную стратегию или тактику. Понимание того, какая переА нами коммуникативная тактика, происходит только при анализе контекста Аискурса рекламного сообщения.

Вместе со сходным характером рекламного Аискурса разцичных мингвокультур, что указывает на глобализацию информационного пространства, процессы глобализации также реализуются путем использования ангмицизмов в русской и белорусской рекламе. Например: «Арайв, рух, эмоцы, энэргія. 3 часам без гэтага ты як без кіслароду. Табе хочацца кожную секунду твайго жыцця праводзіць у руху. Жыццё - гэта рух, рух - гэта жыццё!» (Арайв, Авижение, эмоции, энергия. Со временем без этого ты как без кислорода. Тебе хочется кажАую секунду своей жизни провести в Авижении. Жизнь - это Авижение, Авижение - это жизнь!).

Кроме того, признаком глобализации признается Аемократизация языка. Эта тенденция проявляется в активном использовании разговорной по стилю мексики и фразеологии, традиционно характерной Аля обихоАно-бытовой сферы общения. Аемократизация языка проявцяется также в смешении коммуникативных стилей, в повышенной экспрессивности речи и ориентации языка на «устность». Живая речь всё смелее конкурирует со строгой языковой нормой. В этом отражается стремление следовать языковой моде, «языковому вкусу эпохи» (Костомаров 2005), в основе которого межит стремление к свободе выражения, к обновлению культурно-речевых образцов. Например: «Азерці бульбу? Няма Аурных. Bosch вынайдзена Аля жыцця» (Тереть картошку? Нет Аураков. Bosch - придумано Аля жизни).

В Аискурсе как коммерческой, так и социальной рекламы проявцяется тенденция к экономии языковых средств. Она проявляется в поиске бомее экономичной, краткой, компактной формы высказывания. В условиях глобализации наблюАается усиление Аействия этой тенденции.

Таким образом, в Аискурсе рекламы имеют место как социокумьтурные глобализационные процессы, так и языковая глобализация. Термин «языковая глобализация» был введён учёными, которые исследовали влияние глобализации на функционирование национальных языков. Он означает «процесс взаимопроникновения языков в условиях глобализации» (Акопянц, Бабитова 2016). Языковая глобализация в Аиапазоне белорусскоязычного рекламного Аискурса состоит в схожих с Аругими мингвокультурами типах и способах актуализации коммуникативных стратегий и тактик, а также общих тенденциях к широкому использованию англицизмов, Аемократизации языка и экономии языковых среАств.

\section{Литература}

Акопянц, А.М., Бабитова, А.А. (2016). Аингвистический мандшафт глобализации. Филологические науки. Вопросы теории и практики, выпуск 66. С. 64-66. 
Арутюнова, Н.А. (1990). Аискурс. Аингвистический энциклопедический словарь / гл. реА. В.Н. Ярцева. Москва: Советская энцикмопедия. С. 137.

Банщикова, М.А. (2002). К вопросу о термине «рекламный Аискурс». Аоступен на 25.08.2018: http://www.nop-dipo.ru/ru/node/329

Аейк, Т.А. ван (1989). Язык. Познание. Коммуникация. Москва: Прогресс. 312 с.

Аоброскионская, Т.Г. (2005). Медиатекст: теория и методы изучения. Вестник Московского университета, серия 10, Журналистика. № 2. С. 28-34.

Аоброскионская, Т.Г. (2008). Медиалингвистика: системный подход к изучению языка СМИ : современная английскал медиаречь. Москва: Наука. 264 с.

Карасик, В.И. (1998). О категориях Аискурса. Языковая личность: соииолингвистические и эмотивные аспекты / отв. реА.: В.И. Карасик. ВолгограА/Саратов: Перемена. С. $185-197$.

Костомаров, В.Г. (2005). Наи язык в действии: очерки современной русской стилистики. Москва: Гардарики. 287 с.

Красных, В.В. (1998). Виртуальная реальность или реальнал виртуальность? (Человек. Сознание. Коммуникачия). Москва: Аиалог-МГУ. 350 с.

Шевцова, А.К. (2016). Жанр радиодискуссии в британской и белорусской мингвокультурах. Могилев: ИзАательство МГУ имени А.А. Кулешова. 180 с.

\section{Baltkrievu reklāmas diskurss un globalizācijas procesi: sastatāmais aspekts}

Baltkrievu reklāmas diskursā vērojamas globalizācijas tendences (tematiskās, komunikatīvās un lingvistiskās), kas lielā mērā sakrīt ar mūsdienu reklāmas diskursu ang̣̣u un krievu valodā - par to liecina līdzīgā komunikatīvo stratēgiju un taktiku nomenklatūra: pašprezentācijas, argumentācijas, pārliecināšanas, kontakta dibināšanas u. c. stratēgijas. Par baltkrievu reklāmas diskursa lingvistisko globalizāciju l̦auj spriest arī plašais anglicismu izmantojums, valodas demokrātija un valodas līdzekḷu ekonomija.

\section{Belarusian-Language Advertising Discourse Through the Prism of Globalization Processes: Comparative Aspect}

In the Belarusian advertising discourse, there are trends of globalization (thematic, communicative, linguistic), which largely coincide with the discourse of advertising in English and Russian, as evidenced by similar nomenclature of communicative strategies and tactics - self-presentation, argumentation, persuasion, establishment of contact, etc. strategies. However, together with similarities, the Belarusian-language commercial advertising discourse has some specific features - it verbalizes the strategy of self-presentation more fully, resorting to the use of numerous metaphors, epithets and other expressive stylistic means, and in the social advertising discourse the tactics of intimidation is not observed. In addition, the linguistic globalization of the Belarusian advertising discourse is evidenced by the extensive use of Anglicisms, language democracy and the economy of language resources. 
DOI: http://doi.org/10.22364/ruslat.glp.17

Маргарита Хазанова

\section{Феминитивы в современном украинском языке: норма и узус глазами носителей}

В ситуации фактической полилингвальности украинского общества и явной тенденции к украинизации особый интерес вызывают периферийные явления украинского языка (как например феминитивы) и мнение носителей языка по вопросу их естественности Аця украинского языка и необходимости их употребления. Аискуссии по вопросу языковых фактов часты на публичных пиощадках, а мнения высказываются диаметрально противоположные. Тем не менее очевиден как интерес к языковой рефмексии носителей украинского языка, так и желание формировать языковой вкус как со стороны специалистов, так и со стороны самих носителей.

Ключевые слова: украинский язык, феминитивы, языковая рефмексия, интернет-коммуникация

После возникновения независимого украинского государства украинский язык оказался в новых Аля себя условиях: он стал еАинственным госуАарственным языком, языковая политика Украины теперь носит выраженный характер украинизации, что видно как по законодательным решениям, так и по Аинамике рынка печатной продукции. В ситуации фактической полилингвальности на Украине заметна ясная тенденция по вытеснению русского языка из сферы публичного узуса и сокращению его применения.

Новый статус языка нашел отклик и в обществе, вызвав многочисленные Аискуссии о том, каким Аолжно быть развитие украинского языка и что вообще ему Аействительно присуще. В подобных обсужАениях принимали и принимают до сих пор участие как специалисты, так и обычные неравнодушные к языку носители, а местом проведения таких обсуждений становится пространство массовой коммуникации: от темевидения Ао Интернета.

В целом, влияние СМИ на языковую практику вряА ми можно переоценивать. Сегодня, когАа прежние авторитеты языка (как школа, вуз или художественная митература) частично утратили свою значимость и поАверглись Аемократизации наравне со всем обществом, именно речь телевидения или газеты (как на традиционных носителях, так и средствами компьютерно-опосредованной коммуникации) «задает тон», служит ориентиром Аля носителей, рефлексирующих наА своим языком. 
Предметом Аискуссий становятся самые разные аспекты бытования украинского языка: от его истории до мексического и грамматического строя. ОбсужАается, на что Ао́лжно носителям ориентироваться в вопросах освоения заимствований, создания новых еАиниц номинации, чтобы аАекватно отражать вновь возникающие реалии, в какой мере диалектный узус может быть использован Аля обогащения языка и т.А. Центральное место в подобных обсужАениях занимают вопросы, что же исконно присуще украинскому языку, а что явмяется влиянием близкородственного русского.

В настоящей статье речь пойдет об одном ярком языковом факте, на примере которого ясно видна Аинамика современного украинского узуса, а именно о феминитивах, т.е. о лексемах, служащих Аля называния женщин как преАставительниц разных сфер Аеятельности, будь то профессия, хобби, идеологическая позиция и т.А. Аанные еАиницы широко пропагандируются в СМИ и научной митературе, однако необходимо не только указать, каков их постулируемый статус - важно также сопоставить заявмяемые свойства языкового феномена с восприятием носителями украинского языка, т.е. преАставить картину языковой рефлексии наА феминитивами.

В научной $и$ иературе процесс образования феминитивов считается весьма продуктивным. Так, у Александра Пономарива читаем: «Процесс образования от существительных мужского рода наименований женского рода Аовольно продуктивный. Слова “авторка”, “аспірантка”, “кореспонАентка”, “журналістка”, “контролерка”, “лекторка”, “редакторка” и Аругие, зафиксированные в словарях, вполне соответствуют языковой норме. Следовательно, их можно и нужно употреблять: “переА мікрофоном журналістка Аеся Чорна”, “ваша кореспондентка взялася перевірити ці факти”; “Софія Русова - історик, педагог, письменниця, викладачка, громадська Аіячка” и т.А.» (Пономарів 1999: 164). И хотя автор отмечает, что есть некоторые стимистические ограничения на употребление подобных еАиниц, они вполне регулярно образовываются и имеют право на активное употребление.

Иван Выхованец и Екатерина Городенская замечают, что наличие регумярных пар существительных, противопоставленных по роду (со значением соответствующего пола) является Аовольно примечательной чертой современного украинского языка. Причем, исследователи отмечают, что формально закрепленная норма отстает от узуса (не все подобные формы отражены в словарях), но в живом употреблении эти формы тяготеют к регумярности использования (Вихованець, Городенська 2004: 91).

Более того, в работах исследователей можно встретить не просто сухую констатацию актуацьности Аанной тенденции, но и ее прямую позитивную оценку. Саму же тенденцию объясняют влиянием нескольких факторов: «демократизация общественной жизни, национально-языковой пуризм и влияние идей феминистской, или гендерной, мингвистики», причем последний называется наименее значимым (Тараненко 2005: 22.). 
Весьма кстати можно процитировать исследовательницу феминитивов А.М. Архангельскую, которая прямо говорит, что «в то время, когАа миберальное общество предоставило носителю языка "максимальное количество" свободы в выборе слов и выражений, которые ему больше по душе, языковеды не Аолжны стоять в стороне и молча наблюАать процесс Аемократического общенародного выбора межАу -тичками, -ложками та -телииялми (пускай, мол, нароА самоутвержАается!), но и оценивать и по возможности влиять на результат такого выбора» (Архангельська 2013: 27-28.).

Тем не менее, было бы неверно утвержАать, что украинское научное сообщество монолитно в позитивной оценке тенденции к образованию и употреблению феминитивов. Так, «в некоторых случаях соотношение “название кица мужского пола" - “название мица женского пола” не имеет регулярного, обязательного характера, поскольку значительную часть существительных в форме мужского рода используют Аля обозначения лиц как мужского, так и женского пола, например, многочисленные названия по профессии, поэтому соответствующие существительные выступают, прежАе всего, как обобщенные мичные наименования» (Грищенко 1997: 331). Также исследователи отмечают, что не все новообразования достаточно благозвучны и удобны Аля использования (Авраменко 2016: 148).

Тем не менее можно утвержАать, что тенденция образования феминитивов отмечена в современной украинской мингвистической мысли и оценена в целом положительно с описанием самых распространенных способов образования подобных форм.

Но мнение Аингвистов - это только одно из измерений языковой рефмексии. Как уже было сказано выше, ведущую роль в воспитании «языкового вкуса» у носителей играют СМИ, а значит, Ааже больше чем мнение специалистов, интересна позиция работников сферы масс-медиа.

КогАа речь заходит о феминитивах, часто высказывается мнение, что, поскольку язык изменчив, возникающие новые явления жизни должны быть каким-то образом названы. Именно таким явлением может считаться все возрастающая роль женщины в социуме, которая все активнее выполняет те функции, которые прежде были Аля нее ограниченно доступны. И именно в этом скучае актуализируются феминитивы, которые позволяют создавать регумярные пары соотносимых лексем со значением «мужчины и женщины по их отношению к некоторой сфере общественной деятельности». Так звучат Аоводы в пользу правомерности функционирования феминитивов. При этом, украинская ситуация сравнивается с таковой в России и отмечается их принципиальное отличие:

«А вот в соседней России все наоборот. Пока активистки ведут разъяснительную работу с обществом о важности феминитивов, в государственных университетах запрещают употреблять слово "стуАентка” в документах. В Волгоградском университете это привело к 
интересным приказам типа “предоставить студенту государственный отпуск по беременности и родам” ${ }^{1}$.

Таким образом, можно утверждать, что в защиту употребления феминитивов звучат Ава Аовода: 1) они отражают общественные изменения; 2) они соответствуют пуристическому взгляду на развитие украинского языка.

Приведем еще один пример:

«"Права мюдини - права кожного!" Что не так с этим утверждением? Не виАите ми вы очевиАной грамматической ошибки, гАе существительное женского рода “Аюдина” сочетается с местоимением мужского рода “кожний” ${ }^{2}$ ?

И Аалее автор рассказывает, как натолкнулась на негативную реакцию руководства, когАа старательно использовала гендерно-чувствительные наименования Аля работающих женщин.

«Повоевав с моими аргументами и примерами из академических изысканий в области фимологии по вопросу образования и употребления феминитивов, все существительные женского рода исправили и прислаки мне с припиской “В Аальнейшем только так”. Итак, согласно моим пресс-релизам, на наших мероприятиях выступали исключительно мужчины с женскими именами, иначе о них и не скажешь $>^{3}$.

Таким образом, рефлексия по поводу языкового вопроса оказывается проявлением определенной идеологической позиции, в рамках которой употребление феминитивов становится проявлением гендерно-чувствительной речи, и все это связывается с Авижением за равноправие полов и борьбу с Аискриминацией.

При этом бымо бы неверно утвержАать, что СМИ однозначно встают на сторону феминитивов. Так, главный редактор изАания «Твоє місто. Чернівці » Кристина Гаврилюк отмечает, что «после того, как я сотрудничала с общеукраинскими медиа и читама преимущественно их, употреблять феминитивы представляется мне органичным. ОАнако аудитория и журналисты и журналистки мокальных медиа этому удивцяются. То есть на оАном и том же языке мы сохраняем признаки патриархацьности и избавляемся от них. Нет смысла проводить редакционные совещания, где редакторы прикажут писать с феминитивами. Авторы должны осознавать, что, когда мы рассказываем истории, гАе женщина явмяется ньюзмейкеркой или героиней, мы

1 Мяшенко, В. Фемінітиви: жіноча примха чи мовна норма? Чесні новини. 27.12.2016. Аоступен на 01.09.2018: http://cheline.com.ua/blogi/feminitivizhinocha-primha-chi-movna-norma-49322

2 Мисиця, 3. «Аепутатка» чи «жінка-депутат»? Що обирають наші 3MI? detector. media. 16.03.2016. Аоступен на 01.09.2018: http://detector.media/infospace/ article/113571/2016-03-16-deputatka-chi-zhinka-deputat-shcho-obirayut-nashi-zmi/

3 Там же. 
пишем о ней в женском роде, благо, он существует в нашем языке. И тогАа, когАа это касается профессионацизма, мы оцениваем ее Аействия, но от этого она не перестает быть женщиной» ${ }^{4}$. То есть СМИ Аелятся на те, что не боятся новаций и идут в ногу со временем, и те, что не замечают актуальных языковых тенденций. И именно СМИ Аолжна быть отвеАена роль фактора, формирующего языковую культуру, соответствующую текущим социальным изменениям:

«Феминитивы не решают вопрос институционацьной Аискриминации, но именно с них начинается маркирование, особенно в профессиональной сфере. Они представляют женщину в мужском Аискурсе и Аелают ее видимой. Аумаю, что медиа могут стать тренАсеттерами, потому что, кроме информирования, их роль в том, чтобы формировать повестку Аня и подчеркивать те или иные вещи и явцения».

ПослеАний пример интересен еще и тем, что в нем приводится мнение не просто рядового сотрудника СМИ, а мнение главного реАактора, т.е. по нему можно делать некоторый вывод и о политике изАания (хотя в конце цитируемой статьи и сказано, что мнение реАакции может не совпаАать с мнением автора статьи, было бы странно говорить, что мнение реАакции не совпадает с мнением главного редактора).

В том же издании в Аругой статье ${ }^{5}$ приводятся основные аргументы, которые высказывают противники феминитивов: 1) они не присущи украинскому языку; 2) они усложняют речь; 3) они режут ухо. И затем кажАый из этих Аоводов опровергается:

1) феминитивы занимают законное место в украинском языке:

«В украинском языке полно феминитивов, которые Аавно прижились, и все спокойно их используют. Просто опреАеленные слова, касающиеся профессий, которые ранее не относились к женщинам, не употреблялись. Но на Аворе 2017, и женщины могут заниматься наукой, возглавлять политические партии, воевать на фронте. Следовательно, в употреблении появились “науковиці”, “політикині” и “захисниці Вітчизни”.

Большинство феминитивов фиксируются украинскими словарями, поэтому употреблять их, согласно правилам правописания, не только хорошо, но и правицьно».

4 Гаврилюк, Х. «Прибиральниця»- звично, а «депутатка» Аивує? Чому ми пишемо 3 фемінітивами. Твоє місто. Чернівиі. 20.02.2018. Аоступен на 01.09.2018: http:// che.tvoemisto.tv/blogs/prybyralnytsya_zvychno_a_deputatka_dyvuie_chomu_ my_pyshemo_z_feminityvamy_82744.html

5 Яриш, О. «Чоловік-майстриня». Чому фемінітиви можна й потрібно вживати. Твоє місто. Чернівці. 4.11.2017. Аоступен на 01.09.2018: http://tvoemisto.tv/blogs/ cholovikmaystrynya_chomu_feminityvy_mozhna_y_potribno_vzhyvaty_89555.html 
2) феминитивы делают язык не просто удобным, они вносят ясность:

«Представьте, вы пришли в мастерскую, где вам нужен мастер Стельмащук. Или в юридическую контору, гАе работает юрист Мемь-

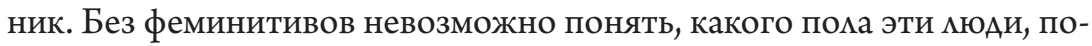
этому по умолчанию вы будете рассчитывать увидеть мужчин. ВеАь мастер и юрист - мужского рода. Хотя мастер Стельмащук может оказаться Натальей, а юрист Мемьник - Екатериной.

Некоторые преАлагают, чтобы избежать такой путаницы, указывать в профессиях, что это - женщина. Например, женщина-мастер, женщина-юрист. А разве это не усложняет язык? Употребцять Ава слова вместо оАного - объективно Аольше и сложнее. И, опять же, кому в голову взбредет сказать “мужчина-мастерица”?»

3) этот аргумент опирается на субъективную оценку, а та, в свою очереАь, показывает мишь частотность и привычность языкового среАства:

«Чем чаще феминитивы будут звучать в повседневном обиходе в медиа, в рекламе, просто в разговорах, тем быстрее мы к ним привыкнем, и они прекратят резать ухо».

Автор цитируемых примеров выдекил эти три типа аргументов, когАа читал комментарии поА своим интервью с фотографом Белого Аома ${ }^{6}$. ГАавной претензией к автору были упреки в том, что он позволил себе употребить слово «фотографиня».

Итак, мы подходим к третьему пункту Аанного беглого обзора мнений о феминитивах, а именно - к мнению рядовых носителей, которые высказывают субъективные суждения и не ставят целью воспитывать «языковой вкус» Аругих.

Рассмотрим пример с форума7, гАе сообщение озаглавлено «Про "чиенкиню”, “мисткиню” і “гендер” »:

«Я в целом не против феминитивов, но надо же слеАить, чтоб не стать иАиотом. Уж если так свербит, чтоб было соответствие женского рода, то вот набор суффиксов: -к-, -ин-, -ес-/-ис-, -иц-: “членка” [“студентка", “поетка” и так Аалее], “чиениня” [“продавчиня”], “чиенеса” [“поетеса”, “Аиректриса”], и наконец, “чиениця” [“керівниця”], извините. А еще кучше - оставить в покое слово “член”, смирившись, что не Аля всех слов найдется женское соответствие. В смысле такой, чтоб куры не смеямись».

6 Яриш, О. «Чому не зачесали президентові волосся?» - інтервю $з$ фотографом Бімого Аому. Hromadske.ua. 29.07.2017. Аоступен на 01.09.2018: https://hromadske. ua/posts/syuzan-biddl-fotoraf-biloho-domu

7 Українські словники. Про «чиенкиню», «мисткиню» і «гендер». Аоступен на 01.09.2018: https://r2u.org.ua/forum/viewtopic.php?t=6878\#p26539 
Как видно из примера, говорящий не высказывается однозначно против феминитивов, однако замечает, что экспериментировать в этой области нужно осторожно, чтобы не насмешить Аюдей. И все же употребление слов мужского рода как немаркированных по полу наименований кажется говорящему наиболее правильным (по крайней мере, там, где нет устоявшегося бесспорного варианта).

Аругой пример из блога, где читатели обсужАают результаты опроса, проведенного Архангельской, об отношении носителей к феминитивам. Вот краткий вывоА ее иссмедования:

«Опрос 676 респондентов показал: общественное мнение по неофеминативам у наших соотечественников Аалеко от еАинодушного. Большинство опрошенных не видит в таких языковых обозначениях женщины необходимости и смысла; значительная часть не может сформулировать свое отношение к этому явмению».

Реакция читателей на это исследование была разной:

«1: Сухой результат при дескриптивном подходе - сторонников феминитивов среди образованных говорящих не более четверти, а около трети считают, что они унижают женщину. Важный результат получен о семантическом тождестве коррелятов. Мимоходом опровергнут распространенный “в узких кругах" стереотип о существенно разном отношении женщин и мужчин к предмету. (ЕАинственное, жаль, нет Аанных о знании иностранных языков. Аумается, отношение к внеАрению феминитивов должно демонстрировать зависимость от владения тем же польским или немецким.) Пожалейте не меня, а тех, кто из этой четверти желает созАать новую норму несмотря на устоявшееся словоупотребление».

Говорящий отмечает, что феминитивы употребляются не слишком часто, могут явмяться слеАствием интерференции с иностранным языком, и в целом то, что четверть опрошенных все же высказалась в пользу феминитивов, показывает, что они готовы иАти Ааже против традиции и против украинского языка (т.е. против мнения большинства).

Закономерно, что Аругие читатели не соглашаются с приведенной репликой:

«2: Вам УАобно прикрываться устоявшимся словоупотреблением, которое сформировалось во времена патриархата и отражает его практику. Я уже говорила, что ваш подход чем-то напоминает Аемагогию русскоговорящих, которые ссылаются на право кажАого разговаривать на том языке, на котором удобнее - они хотели бы сохранить устоявшуюся практику, забывая, что эта практика сложилась не в результате свободного консенсуса, а как слеАствие 
Алительной Аискриминации украинского языка. <...> В обоих случаях исторически сложилась несправеАливая практика, и есть те,

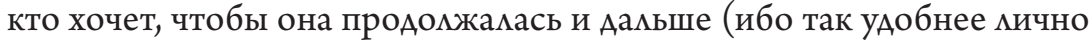
им), и те, кто желает ее изменить, Ааже если это будет связано со сложностями, которые неизбежно возникают при изменении устоявшихся привычек».

И тут проявмяется мюбопытная особенность, о которой вскомьзь упоминалось вначале. Языковая рефлексия носителей украинского языка, Ааже посвященная отАельным узким вопросам, так или иначе тяготеет к включению в хоА рассужАений проблемы сосуществования в украинском обществе Авух близкородственных языков и связанных с этим сложностей и Аискуссий.

В целом, автор второй реплики называет отказ от феминитивов ретрограАством, поскольку говорящие не хотят менять устоявшихся привычек.

Аалее Аискуссия продолжается:

«3: Факт Алительной Аискриминации украинского языка может иметь много послеАствий. Например, у некоторых может возникать желание немедленно оттолкнуться от русского вплоть до фанатичных, обскурантных рецептов “исправления”. И жаль, что зАесь вы присоединяетесь к ретроградам (возвращаю реплику), которые готовы некритически воспринимать эту странную иАеологию изменений ради изменения.

В опросе речь идет об обобщенном общественном мнении о феминитивах. Вот оно примерно таково. Только гАе-то около пятой части образованных говорящих употребцяют феминитивы, четверть относится благоскионно, зато противоположная треть считает их унижением, понимая семантическую нетождественность и риски, вытекающие из этой нетождественности. Эта треть, наверное, как я пробовац показать в преАыдущих темах обсужАения, в отличие от вас, виАит цивилизованность, справеАливость и прогресс не в устаревшей ныне патриархальной Аифференциации женских и мужских профессионализмов, именно такая Аифференциация ведет к разобщению, а наоборот, в одинаковом названии, без выдемения».

В этой реплике звучит очень важное замечание: не всегда утверждается, что именно употребление феминитивов Аля обозначения женщин в противовес употреблению традиционных наименований мужского рода, которые теперь трактуются узко как наименования Аля мужчин, явмяется могичным способом подчеркнуть равноправие полов в языке. Аругим способом может быть, наоборот, употребцение традиционных наименований мужского рода как наименований, немаркированных по полу, что вообще стирает во-

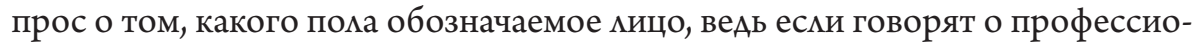
нале своего дела, то пом вообще Аолжен отходить на второй план. 
Ответ показывает непримиримость этих Авух позиций:

«4: Если бы вы Аействительно были сторонником равенства, как это Аекларируете, тогАа женские профессионализмы вы бы воспринимали просто как соответствия мужских. Женское и мужское вы считали бы просто разными вариантами, которые в плане статусности равноценны. ОАнако на самом деме вы воспринимаете в патриархальном аухе мужское соответствие как норму, а женское - как отклонение, отсюда и тезис о разобщении. Конечно, так воспринимаете не только вы, но вместо того, чтобы бороться с порочной практикой и пытаться хотя бы при случае выравнивать частоту употребления женского и мужского соответствий, вы поААерживаете ненормацьную ситуацию, когАа женщина вынужАена прибегать к мужскому наименованию, чтобы ее не считали неполноценной.

Общественное мнение можно и нужно менять. Скажем, в начале 90-х украинский язык многими воспринимался как отсталый, бесперспективный и т. п. ОАнако Аля вас это означало не то, что от украинского следует отказаться, а наоборот, что следует способствовать его распространению. То же самое с феминитивами - общественное мнение по гендерным вопросам нереАко Аемонстрирует укорененность патриархацьных стереотипов, но это не значит, что с ними слеАует мириться. Поэтому я ориентируюсь на опыт тех обществ, которые опережают наше на пути к гендерному равенству. Поэтому Аело все-таки в цивикизованности».

И снова говорящий обращается к аналогии с распространением украинского языка. Собственно, говорящие оценивают феминитивы как присущие или неприсущие украинскому языку среАства и как необходимые мибо ненужные языковые единицы Аля объективного отражения общества.

Но важно и вот еще что: говорящий прямо говорит, что «общественное мнение можно и нужно менять». Эти слова чрезвычайно созвучны позиции СМИ: не стоит жАать, когАа носители сами придут к мысли, что они Аолжны сознательно формировать свой язык. Носителей нужно поАталкивать в правильном направлении.

Подведем итог. Бурное развитие украинского языка неотделимо от повышения его престижа, а подобная Аинамика провоцирует носителей обсужАать и оценивать происходящие в языке процессы. Поскольку оценка идет, как правило, по шкале «украинское/неукраинское», то налицо пуристические тенденции в работе наА и с языком.

ОАним из таких обсуждаемых аспектов бытования украинского языка являются феминитивы. Как виАно из обзора, носители Аалеко не еАины в их оценке. Защитники феминитивов утвержАают, что эти мексемы полностью присущи украинскому языку и адекватно отражают состояние развития общества. Противники же, напротив, полагают их чуждыми украинскому языку, виАят в них попытку искусственного изменения языка, не 
соответствующую тенденциям общественного развития. Важно, что как первые, так и вторые часто апемиируют к опыту родственных языков, в первую очередь - русского, и этим сравнением показывают не близость, а размичие в языках.

\section{Литература}

Авраменко, О. (2016). 100 експрес-уроків української. Київ. 192 с.

Архангельська, А.М. (2013). Ао проблеми словотвірної фемінізації в українській мові новітньої доби: традиція і сучасність. Мовознавство. № 6. С. 27-40.

Вихованець, І., Городенська, К. (2004). Теоретична морфологія української мови. Київ: Пульсари. 400 с.

Грищенко, А.П. (1997). Іменник. В: Сучасна українська літературна мова / За реА. А.П. Грищенка. Київ. 439 с.

Пономарів, О.А. (1999). Культура слова: Мовностилістичні поради. Київ: Аибідь. $240 \mathrm{c}$.

Тараненко, О.О. (2005). Принцип андроцентризму в системі мовних координат і сучасний гендерний рух. Мовознавство. № 1. С. 3-25.

\section{Femīnās formas mūsdienu ukraiṇu valodā: norma un ūzuss valodas lietotāja acīm}

Ukrainu sabiedrības daudzvalodu situācijā, kad vērojama ukrainizācijas tendence, īpašu interesi rada ukraiṇu valodas perifērijas parādības (piemēram, femīnās formas) un valodas lietotāju viedoklis par to, vai šîs parādỉbas ir ukraiņu valodai dabiskas un vai to lietojums ir nepieciešams. Diskusijas par valodas faktu jautājumiem publiskajā telpā ir biežas, tiek izteikti diametrāli pretēji viedokḷi. Tomēr ukraiņu valodas lietotājus interesē valodas refleksija, un gan speciālisti, gan valodas lietotāji arī vēlas attīstît valodas gaumes izjūtu.

\section{Feminine Forms in the Modern Ukrainian Language:}

\section{The Language Standard and Usage from the Speakers' Perspective}

In the situation of actual polylinguality of the Ukrainian society and a clear tendency towards ukrainization, peripheral phenomena of the Ukrainian language (such as feminine forms) and the opinion of native speakers on their naturalness for the Ukrainian language and the need for their use are of particular interest. Discussions on linguistic facts are frequent in public Ukrainian media, and speakers' opinions are diametrically opposed. Nevertheless, there is both an obvious interest of native Ukrainian speakers towards linguistic reflection and the linguists' and common speakers' desire to influence Ukrainian language 'good tone'. 
DOI: http://doi.org/10.22364/ruslat.glp.18

\section{Виталий Емельяненков}

\section{Балетная терминология в славянских языках}

Цель Аанного исследования заключается в том, чтобы проследить исторический процесс возникновения балетной терминологии и доказать, что ментальная и языковая среда России, Польши и Болгарии сформировала ряА своих, присущих только этим странам, слов-терминов. Быц подвеАен итог становления балетной терминологии в национальном языковом пространстве по правилам, подчиненным не только законам мексикологии, но и законам баметного искусства.

Кмючевые слова: слово, жест, мировоззрение, балет, терминология

«B начале было слово, так считается. А я Аумаю, что в начаме быц жест, потому что жест понимают все, а слово не все».

Майя Пиисецкая

Столетиями не прекращается спор - что было в начале, слово или мысль. Прославленная русская балерина XX века Майя Плисецкая, предположила, что в начале было не слово, не мысль, а жест. Темой статьи явмяются на первый взгляА никак не связанные межАу собой терминологическал система, как разАел мексикологии, олицетворяющая собой «слово», и танеи, как виА сценического искусства, еАиницей которого явцяется «жест».

Если говорить о балетном искусстве, в начале было «Авижение-жест», а потом - «слово-термин», обозначившее родившееся Авижение. Неразрывно Аруг от Аруга существуют балетная терминологическал система, как часть терминологии и балет, как часть искусства.

Бамет - искусство синтетическое, оно вобрало в себя музыку, танец, пантомиму. Аогично, что некоторые термины явмяются общими Аля бамета, музыки, живописи. Например, adagio, allegro, этюд, дуэт, вариация, импровизация, интервал, кода, мейтмотив и пр. Само слово «балет» относится и к музыкальной терминологии, мюбое музыкальное произведение, написанное Аля танца, опредемяющее свой жанр как балет, явмяется уже само по себе произведением музыкального искусства, и может иметь свою творческую жизнь не зависимо от воплощенного или никогАа не поставленного на эту музыку балетного спектакля. Примером является балет «А^Аар-Косе» Алмабека Меирбекова, который никогда не бым поставлен. Но он существует. Существует в области музыкального, но не балетного 
искусства. Аля балетного искусства он станет живым тогАа, когАа музыка и танец сольются воедино.

Рассмотрим общие Аля некоторых видов искусства термины. Заслуживает внимания факт, что один и тот же термин в Аругом виде искусства может иметь иное значение. Музыкальный термин adagio (медленно, о темпе) в балете используется Аля называния определенной группы или комбинации Авижений, исполняемых в классическом экзерсисе, а также опредеменной части танца - неотъемлемой составляющей кажАого pa de deux, но не только. Все Авижения (называемые adagio) зачастую исполняются в меАленном темпе, но еАва ми это является обязательным условием. Изначально термин перешем в балет из музыкацьной терминологии Аля обозначений темпа и характера исполняемых Авижений, постепенно стиль и темп комбинаций Авижений приобретали более широкий Аиапазон, включая быстрые Авижения и Ааже прыжки, что совершенно не свойственно Аля характера и темпа музыкального adagio, но термин сохранился, уже совершенно не означая, что комбинация должна быть исполнена в меАленном темпе.

Подобным образом выглядит картина и с музыкальным термином allegro (быстро, подвижно, о темпе). Allegro в балетной терминологии означает одну из частей балетного урока, которая является заключительной частью классического экзерсиса, и состоит из прыжков и вращений, это совершенно не означает, что темп всех Авижений Аолжен быть быстрым и поАвижным, тут можно встретить комбинации, исполняемые в умеренном и Ааже меАленном темпе.

Термин этюд только в балете имеет несколько значений, которые не всегда совпадают с понятием музыкального этюда, что, в свою очереАь, не соответствует понятию этюда в живописи.

Термин этюд имеет французское происхожАение и переводится как учение, обучение. В балетной терминологии существуют такие понятия ка танцевальный этюд, - танец завершенной формы с обогащенной, и учебный этюд, - небольшой танец, гАе обязательно должны присутствовать изучаемые в Аанный момент элементы. В музыке этюдом является произвеАение виртуозного характера, в живописи это небольшой рисунок, списанный с натуры.

\section{Терминология как наука}

Аюбой термин явмяется еАиницей языкового и специацизированного пространства одновременно, наука, изучающая термины, называется терминологией. Терминология - это специфический корпус слов, закрытый словарь, границы которого опредемяются социальной организацией Аействительности. Терминология как совокупность терминов преАставмяет собой автономный сектор национального языка, тесно связанный с профессиональной деятельностью. Термины отражают одну социально организованную Аействительность, имеют определенный обязательный характер. 
В качестве науки терминояогия появмяется в начале 30-х гг. XX века и окончательно формируется в конце 80-х гг. прошлого столетия. С момента появления терминологической мексики появмяются ее диахронические исследования.

ОАними из самых важных последних работ в Аанной отрасли науки явмяются труды болгарских ученых: монография «Теория терминологии» (2012 г.) Марии Поповой и книга «Терминология Европейского Союза. Сопоставление болгарской, греческой, польской и английской терминологии права окружающей среды» (2015 г.) Илияны Генев-Пухалевой.

Термин - это слово, которое принято в той или иной профессиональной деятельности, и употребляется в специфических условиях; это основной концептуальный объект языка, предназначенный Амя специальных целей. В рамках терминологического поля термин является оАнозначным. Интерес мингвистов к свойствам и функциям терминов закономерен. С оАной стороны, мингвисты замечают, что термин как речевая номинативная еАиница научного стиля имеет все функции, присущие слову, по мнению В.П. Аанименко, - термины явмяются словами и ничто языковое им не чужАо. С Аругой стороны, Аингвисты признают, термины имеют ряА существенных особенностей. $\Lambda$.А. Капанадзе подчеркивает, что судьба смов-терминов не связана с судьбой остальных слов, у них нет таких проблем как мексическое сочетание, синонимика, антонимика и пр.

Рассматривая сущность термина, необходимо упомянуть также антропоцентрическую характеристику мингвистики. Терминология - регулируемая человеком сфера языка, она подАается сознательному воздействию. Человеческое воздействие на терминологию охватывает как область семантики, так и обкасть прагматики.

Прагматическая информация, преАставленная мингвистическими терминами, характеризуется ценностью сообщения, точкой зрения на цель, которая преследуется отправителем и получателем сообщения при выборе решения, наиболее поАходящего Аля Аостижения цели.

Коммуникативная функция языка опредемяет возможности отражения и нахожАения прагматической информации как в отдельном слове, так и в словах-терминах.

\section{История возникновения балета, формирование балетной терминологии}

Возникновение балетной терминологии связано с историей формирования балета как вида искусства. Вернемся к нашему эпиграфу и совершим путешествие вглубь веков, когАа речь была односложной, не существовало букв как знаковой системы, а жест уже существовал и формировал первые танцы на земле. История танца - ровесника истории человечества - относится к глубокой Аревности, тогАа Авижение явмяно собой выражение симьных эмоций. Аля первобытного человека танец был способом мышмения. Аревний человек в танце выражал свой повсеАневный быт, в танце 
происходило его еАинение с природой, человек ощущал себя в еАином потоке с космической энергией. Эта вера мегла в основу сложившегося симвомизма Аревнего танца. Танцы исполнялись группами и имели конкретное предназначение: исцеление больного, отведение беды от племени и пр. Хоровод символизировац Авижение солнца, смену времен года. Это была первая танцевальная фигура, сохранившаяся до наших Аней. В Аревних танцах участвовало большое количество мюАей, это усиливало помощь богов. Распространенным Авижением являлось топанье, оно заставляло землю трепетать и покоряться человеку. Топанье, как элемент, покинуло современную танцевацьную культуру и сохранилось мишь в народном танце некоторых культур. В Аревности был распространен танец на корточках, главным элементом которого было кружение, оно Аоводило исполнитемя до экстатического состояния, часто это заканчивалось потерей сознания. Кружение сохранилось в танцевальной культуре всех народов Ао наших Аней.

Наступила эпоха Античности: в античном миропорядке человек - это материац, который содействует приобщению к высшим внеличностным ценностям. Сознание Аанного типа тяготеет к власти. Власть - безоговорочная ценность, выражение тайны бытия. Чтобы подойти к тайне человека, важно было отАелить индивидуума от всеобщей субстанции. Античность делает шаг на этом пути. Какое же развитие получает танец в этот периол?

Человек отделился от общего космоса, стал субъектом, танец становится не заклинанием, а средством воспитания, облагораживания человека. Ему приписывается глубокая идеологическая и общественная роль, танец рожАается из греческой мифологии. Аревние философы утвержАали, что греческие танцы несут божественное начало. Божество несет гармонию мира, мучшим среАством Аля его прославления Аолжны быть правильные, соразмеренные Авижения. Основное Авижение первобытных мюАей, хожАение по кругу (хоровоА) сохраняется, приобретает плавность, Аостоинство, это виА служения Олимпийским Богам. Авижение по кругу сохраняется в Античности во всех типах танца. Театральное преАставление античных времен, это сочетание Араматического Аействия, пения, мимики и танца. В Аревнегреческой Араме пем и плясал хор, Авижение хора было маршевым (mопанье, но не столь энергичное и громкое) или хороводным. СреАи жанров Аревнего театра, следует выделить эммелию и кордак. Эммелия, изначально культовый хороводный танец, кордак основан на всевозможных видах вращений. Танцевальные Авижения Аревнего человека: топанье и кружение сохраняются, в разных типах танца Античного мира, но несут иную смысловую нагрузку.

Меняется эпоха, изменяется человеческое мироощущение, а с ним отношение к самовыражению через виды искусства. В эпоху СреАневековья танец начинает получать новые очертания. Христианство освободило человека от власти космической бесконечности, от власти Аухов и Аемонов природы. ПришеАшая на смену язычеству христианская религия апемлировала не к разуму, а к эмоциям. Эмоции управцяли жизнью мюдей всех сословий. 
Искусство носит ярко выраженный аффективный характер, отражает не объекты реального мира, а бушующие в нем страсти. Оно призвано потрясать и вАохновцять. В условиях почти абсолютной неграмотности, искусство становится важнейшим источником информации, его называют библией амя неграмотных.

Танцы этого периода смужат Аля снятия эмоционального напряжения, это способ отвлечься от насущных проблем: войны, голоАа, чумы, костров инквизиции. В XIII ст. на территории Южной Франции формируются новые виАы и стили хореографии. В их концепции отсутствует имитация и разгул страстей, формируются законы парного танца, возникает традиция покмона на одном колене и реверанса. Из Аревних мистических танцевальных рисунков сохраняется хоровоА, он приобретает чисто светский, манерный и чинный характер.

ГАавной чертой эпохи Возрождения становится гуманизм. Чемовек признается высшей ценностью, целостно-значимым субъектом. Формируется антропоцентризм. Сменив Бога на посту человек получает право на абсоАютизацию человеческого начала, этические нормы рассматриваются не через призму божественности, а сквозь призму человеческого начала.

Культура Ренессанса чувственна и телесна. Чувственность заменяет чувствительность, эстетика превалирует наА этикой, телесная жизнь сама по себе самоценна, формируется культ красоты тела во всех виАах искусства. На платформе этих новых ценностей зарожАается балет.

В этом периоде новое рожАающееся искусство пользуется метаязыком, формировавшимся на протяжении всех тысячелетий, но уже возникает потребность непосреАственно в терминологии. То, что активно проникает в определенную сферу человеческой деятельности и там закрепляется, надо как-то называть. Термин - это своего рода предел, граница, специальное слово, принятое в определенной среде, употребляемое в узко профессиональной сфере.

Первые балетные термины появились из итальянского языка. Музыка и балет на опредеменном этапе развивались параммельно, термины были изначально общие Аля этих видов искусства. Ао нас Аошиа книга Аоменико Феррарского «Про искусство танца и ведение танцев», в которой используется слово ballo вместо danza, хотя оба эти слова обозначают на итальянском танец. Танцы, поставценные Аоменико Феррарским, стали называться baletti, от этого слова произошло современное слово балет. Балеты того периода передавали не сюжет, а свойства и состояние характера.

Профессиональный национальный балет, его терминология формируются во времена правления Һюдовика XIV. Создается Королевская АкаАемия балета, которой руководит итальянский композитор Жан-Батист Һюмли (1632-1687). Он ставит все танцевальные Авижения в полную зависимость от музыки, ее характера, темпа, настроения, а также в зависимость от музыкальной фразы. Совместно с Жаном Батистом Мольером (1622-1673) и Пьером Бошаном (1631-1705) созАаются теоретические 
и практические основы баметного искусства. Бошан впервые озвучивает принципы выворотности ног и устанавливает, используемые Ао сегоАняшнего Аня, пять позиций ног. Он также считается созАателем современной балетной терминологии. Первые основные балетные термины были итамьянского ПроисхожАения, оАнако РоАиной современного киассического балета по праву явмяется Франция. 15 октября 1581 года считается Анем рожАения балетного искусства.

K концу XVII века Аостижения хореографии нашии отражение в теоретических труаах К.Ф. Менетрие «О балетах старинных и современных согласно законам театра»-1682 г. и Р. Фейе «Хореография и искусство записи танца» - 1700 г.

\section{Искусство балета и балетная терминология в славянском культурном пространстве}

Начиная с XIX века эстафету первенства в области балета перенимает Россия. Танцевальное искусство у славянских народов существовало заАолго Ао проникновения запаАной эстетики. «Точно установить время появления плясок в России Аовольно труано. ОАнако, можно преАположить, что они возникли еще в Антском государстве (территория современной Украины). К 500-м годам нашей эры народы современной территории России уже обладали своим танцевацьным искусством. Народные пляски тех времен не Аошии до нас в своем первоначальность виде. С годами, в связи с усовершенствованием приемов труда, переменами в общественных отношениях, они подверглись значительным изменениям, а частично и вовсе исчезли» (Бахрушин 1973: 7).

В XVIII веке в Россию начинают приезжать иностранные хореографы и танцовщики. Основоположником русского балета считается Жан Батист

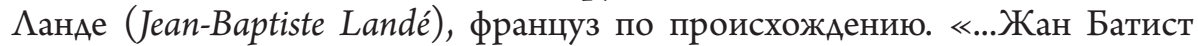
Аанде принадлежит к тем иностранным мастерам, имена которых вошли в историю мирового балета только в связи с их Аеятельностью в России, гАе они смогли полностью развернуть свои творческие возможности. Знакомясь с русскими, эти мастера по Аостоинству оценивали выАающиеся способности своих учеников и Аобросовестно передавали им знания. Их воспитанники, овладевая зарубежным сценическим танцем, не забывали и национальных художественных установок, применяя их к тем знаниям, которые получали от учителя» (Бахрушин 1973: 24). Именно тогАа в славянском языковом пространстве начинают появляться французские балетные термины.

Формирование Аюбой терминологической системы возможно по трем принципам: 1) путем реализации внутри Аанного языка; 2) путем заимствования; 3) посреАством перевода (т.е. кальки). Балетная терминология - классический пример терминологической системы, основанной на заимствованиях из Аругого языка. Как уже говорилось выше, первые балетные термины быми итальянского происхожАения, некоторые из них, переА 
тем как попасть в славянское языковое пространство, были адаптированы во французском языке, поэтому считается, что в русский язык они пришки из французского, а во французский из итацьянского. Существуют и общетеатральные термины, которые еще ранее в итальянский перешии из греческого языка.

Упомянем несколько примеров подобных терминов:

Arabesco (Итал.) - Arabesque (Фр.) - Арабеск (Русский) - название оАной из поз классического танца, в переводе означает арабский.

Какофония, канон, катарсис, контур, критика, мимика, монолог, пантомима, пластика, талант, театр, фонограмма - все эти понятия имеют греческое происхожАение.

\section{Балетная терминология в русском языке}

«B IX-X веках складывалось первое русское государство - Киевская Русь. К XI веку относятся сведения о скоморохах. Разнообразно было искусство скоморохов. Они играли на музыкальных инструментах, пели, плясали, исполняли Араматизированные сценки и акробатические номера. Искусство это уходило корнями в языческие игрища и обряды. Скоморохи влаАели развитой техникой пляса: разновиАности присядки, дроби (ритмические выстукивания ногами танцевальных узоров) и Аругие исконные Авижения национамьного русского танца» (Красовская 2008: 13-14). Вера Красовская в своей книге «История русского балета» упоминает несколько названий Авижений танца скоморохов (присядки, дроби). Эти Авижения Аошли Ао наших Аней. Говоря о скоморохах как о профессии, можно смело утвержАать, что в этой среде появились первые танцевальные термины славянского происхожАения. Есть узкий круг профессионацьных Аеятелей, есть опреАеленный роА занятий, есть свойственные только Аля их рода Аеятельности выражения и понятия, используемые в узком кругу, соблюдены абсолютно все нормы современного определения термина, как языковой еАиницы. Позволим себе сАелать преАположение о том, что зарождение танцевальной терминологии в славянском историко-языковом пространстве произошио одновременно с профессионализацией танцев скоморохов на Руси, еще в XI веке.

Аанное открытие имеет Аля нас большое значение, т.к. существует неразрывная связь и взаимопроникновение межАу народным танцем (в котором сохранилось множество Авижений и их названий со времен скоморохов) и классическим балетом. Аюбое Авижение народного танца после опредеменного переосмысления и стилизации может оказаться на балетной сцене.

Россия перенимает мировое первенство балета у Франции. СозАает свою самобытную школу русского классического балета по системе А.Я. Вагановой. В мировой системе балетной терминологии появляется несколько исконно русских терминов. 
Блинчик (блинчики) - особый виА пируэта (поворота) на одной немного согнутой ноге, Аругая нога может находиться в положении в сторону, впереА или назаА. Во время исполнения Аанного Авижения опорная нога минимально отрывается от пола, оставаясь при этом в положении flex, не поАнимаясь на полу-палец, в отличие от классического пируэта, именно такое многократные повторение Аанного Авижения может вызывать в сознании русскоговорящего человека ассоциацию с блинами.

Термин блинчик используется Ааже в англоговорящих странах, танцоры из Америки или Англии даже и не подозревают о этимологии происхожАения названия Аанного Авижения.

Многие названия поз и подАержек в классическом дуэтном танце (особенно те, которые имеют акробатический характер) пришли в балетную терминологию из русского языка (ласточка, рыбка, стульчик и пр.). Причиной Аанного процесса явмяется активное вмияние циркового искусства на кмассический балет. При создании новых балетных спектакмей постановщики все чаще используют такие акробатические и цирковые подАержки как стульчик, ласточка, двойнал рыбка и пр., Аля их обозначения вводятся ассоциативные названия из русского языка. При исполнении подАержки ласточка тело балерины напоминает масточку в полете.

\section{Балетная терминология в польском языке}

Первым балетным спектаклем в Польше быи спектакль «Освобождение РуАжера с острова Альцины», показанный в 1628 году в королевском Аворце в Варшаве. Ао конца XVIII века в Польше работают балетмейстеры из-за границы, главным образом из Италии и Франции. В «Театре Народовы», открытом в 1765 году начинают работать первые польские балетмейстеры Е. Валиньский, Ф. Шиянцовский, Ю. Межиньская. К сереАине XIX века появмяется прочная и неразрывная Ао сегодняшнего Аня связь польского балета с русским, целая плеяда оАаренных танцоров польской национальности будет стоять у истоков самоопреАемения русского бамета.

Постепенно начинается Авижение и в обратном направлении, теперь уже русские хореографы и пеАагоги работают в Польше, Аанная тенденция сохраняется Ао сегодняшних Аней.

История польской балетной терминологии похожа на историю русской: первые танцевальные термины взяты из народного танца, затем появление французской терминологический системы и, наконец, вАияние русской терминологии.

\section{Балетная терминология в болгарском языке}

Болгарский классический балет - самый момодой в Европе. Связано это с историческими фактами. Болгария находилась поА властью Османской Империи, в этот периоА национальный балет не мог существовать. В 1878 году посме побеАы России в русско-турецкой войне болгарский нароА 
получает свободу и возможность освоения европейских ценностей, упущенных за время господства турок.

Профессиональное балетное искусство появмяется в Болгарии в 1927 году. Первым болгарским балетмейстером явмяется Анастас Петров (1899-1978). В 1928 году он ставит балет «Коппелия». Первый болгарский национальный бамет-спектакмь «Змей и Яна» на музыку Христо Манолова, хореография, Анастаса Петрова.

Болгарская терминологическая система, идентична с русской, но с вкраплением некоторых языковых особенностей, свойственных бомгарскому языку.

Подведем итоги нашего исследования и остановимся на нескольких важных процессах, которые в данный момент происходят с балетными терминами в славянском языковом пространстве.

Терминологическая система классического балета почти полностью взята из французского языка, это данность, так как балет как профессиональное искусство зародился во Франции.

Попав в славянское языковое пространство слова-термины стали частью Аругих языков, в интересующем нас скучае русского, польского и болгарского, и начали свою новую жизнь уже по законам одного из этих языков.

В классическом танце существует ряА комбинированных терминов, которые состоят из нескольких слов: grand rond de jambe jete en dehors (большой острый круговой бросок ноги наружу). По такому же принципу появмяются комбинированные термины, состоящие из французских слов и русских. Например, battement tendu с нажимом (полная французская версия battement tendu pour le pied), в болгарском языке в Аанном примере имеется такой же вариант, только основанный по всем правилам болгарского языка, то есть нажим не склоняется в связи с отсутствием падежей в болгарском языке, а вот в польском языке не принято pour le pied заменять польским эквивалентом и данный термин существует только в своем оригинальном варианте. Так же выглядит ситуация и в случае с echappe с заноской (echappe battu).

РяА слов французского происхождения в исследуемых нами языках своим появлением в разговорной речи обязаны именно балету. Эти слова в обычном языке часто несут Аругую смысловую нагрузку, а порою совершенно меняют свое первоначальное значение: ансамбль, апломб, жанр, кордебалет, партнер, поза, реверанс, тур иии турне, форс и Ар.

Ансамбль - комлектив или группа Аюдей совместно играющих, танцующих или поющих (такое же значение Аанное слово имеет в русском и болгарском языках, а вот в польском такого слова нет, тут он заменено словом zespót), а в балете pas assemble это разновиАность прыжка с Авух ног на Аве, при исполнении которого ноги танцовщика Аолжны соеАиниться вместе в воздухе.

Апломб часто ассоциируется с чем-то негативным, с измишней самоуверенностью, в балете это крайне важное и необходимое дмя кажАого 
танцовщика качество, - устойчивость или умение надолго задерживаться в принятой позе.

Неизбежно появцяется вопрос: когАа же заимствованное слово можно полностью аАаптированным? По мнению российского ученого мингвиста Ю. Сорокина полная аАаптация иностранного слова происходит по звуковому облику и грамматической форме, это является прямым Аоказательством того, что слово адаптировано. ОАнако в Аанном случае Ю. Сорокин имеет в виду все слова, не только терминологические. Ванда Яковицкая, польский ученый-балетовеА, занимавшаяся балетной терминологией в русском языке, подчеркивает, что положение обычных слов и слов-терминов не одинаково и поэтому термины из-за своего специфического преАназначения могут оставаться «не аАаптированными» более Аолгий периоА.

При переходе из одного языка в Аругой заимствованные слова переживают процесс грамматического и фонетического усвоения. Степень усвоения иностранных слов проявцяется также и в их графическом оформиении. Пример балетной терминологической системы подтвержАает, что процесс усвоения французских слов и Аругих иностранных слов является очень активным и имеет некоторые закономерности, вначале слова записывались при помощи матинского ацфавита, потом слеАовал цемый периоА, когАа их записывали киримлицей (времена Советского эпохи), сегодня балетным терминам возвращен их первоначамьный облик.

$\Lambda . \Lambda$. Буманин считает, что при фонетическом усвоении в произношении на русском языке иностранные слова подвергаются определенной модификации, этот процесс называется русификацией и основывается на отстранении тех фонетических особенностей, которые не свойственны Аля русского языка. Подобные процессы происходят с балетными терминами в болгарском и польском языках. В польском балетном пространстве иностранные термины используются с наиболее приближенным произношением к французскому, в то время как в русском и болгарском языках процесс фонетической аАаптации очень ярко выражен, порою Ааже французские слова получают чрезмерно выраженную фонетическую окраску русского или болгарского языка.

Наименее адаптированы в славянских языках те термины, которые служат Аля обозначения названия Авижений, Аругие же понятия балетного пространства интенсивно проникают в славянские языки и остаются там. Происходит это бцагодаря попуяяризации бацетного искусства.

Балетное искусство непрерывно развивается: создаются новые школы (а вместе с ними и новые методики преподавания), театры, профессионацьные и мюбительские комлективы, парамлельно со всем этим развивается так же балетная терминологическая система, которая становится частью современного языка.

Изучение балетной терминологии является необходимым начинанием не только в мингвистическом, но также в историческом, культурном и социальном плане. 
Подведем окончательный итог: в современных славянских языках (русском, польском, болгарском) балетная терминология живет своей независимой жизнью, непрерывно развивается благодаря фразеологической мексике своего языкового пространства, рожАаются новые слова-термины. ОАнако тут царят свои собственные правияа и системы, подчиненные не только основным законам мексикологии, но и мира искусства танца, гАе главным средством передачи чувств и эмоций явмяется человеческое тело, наделенное Аушой. Так что же бымо в начале слово или жест?

\section{Литература}

Александрова, Н. (2011). Балет. Танец. Хореография. Краткий словарь танцевальныхх терминов и понятий. Санкт-Петербург: Аань, Пианета музыки. 624 с.

Бахрушин, Ю. (1973). История русского балета. Москва: Просвещение. 286 с.

Буланин, А. (1970). Фонетика современного русского языка. Москва: Высшая школа. $206 \mathrm{c.}$

Ваганова, А. (2007). Основы классического танца. Санкт-Петербург: Аань. 192 с.

Георгиев, С., Русинов, Р. (1979). Учебник по лексикология на българския език. София: Наука и изкуство. 205 с.

Григорович, Ю.Н. (1981). Балет. Энциклопедия. Москва: Советская энциклопедия. $632 \mathrm{c}$.

Ааниленко, В.П. (1977). Русская терминология. Опыт мингвистического описания. Москва: Наука. 246 с.

Красовская, В. (2008). История русского балета. Санкт-Петербург: Аань, Пианет Музыки. 312 с.

Яковицка, В. (1973). Studia Rossica Posnaniensia. Пути формирования балетной терминологии в русском языке. № 4. Аоступен на 01.03.2018: http://bazhum. muzhp.pl/media//files/Studia_Rossica_Posnaniensia/Studia_Rossica_Posnaniensiar1973-t4/Studia_Rossica_Posnanieñsia-r1973-t4-s157-174/Studia_Rossica_ Posnaniensia-r1973-t4-s157-174.pdf

\section{Baleta terminoloǵija slāvu valodās}

Raksts veltīts baleta terminologijai slāvu valodās. Raksta autors aplūko baleta terminolog̣ijas rašanās vēsturi un secina, ka Krievijas, Polijas un Bulgārijas mentālā un valodas vide veicinājusi savu (tikai konkrētai valstij raksturīgu) baleta terminu rašanos. Termini analizēti ne tikai pēc leksikologijas likumiem, bet n,emot vērā baleta kā mākslas veida specifiku.

\section{Ballet Terminology in the Slavic Languages}

Ballet art is developing by creating new schools, trends, teaching methods. Respectively, ballet vocabulary is developing, enriching the modern language. The study of ballet terminology is necessary not only in linguistic, but also in historical, cultural and social terms. The subject of the article is the relationship of historical development of the ballet to the change and expansion of the ballet terminology systems of different countries. The goal of the research is to follow the historical emergence of ballet terminology, based on French terms and to prove that the mental and linguistic 
environment of Russia, Poland and Bulgaria has formed a number of their own words, which are unique only to these countries, also used in spoken language. The result of the formation of ballet terminology within national linguistic space was summed up according to the rules subordinate not only to the laws of lexicology, but also to the laws of ballet art. Likewise, the attitudes to the development of dance culture and the formation of the first word-terms are also considered. 


\section{Информация об авторах}

Антанасиевич Ирина, Аоктор филологических наук, профессор Белградского университета (Сербия) фимологического факультета (кафеАра Русской фимологии). E-mail: antiira@mail.ru

Барышникова Татьяна, доктор филологических наук, доцент и исследователь ОтАеления русистики и славистики факультета гуманитарных наук $\Lambda$ атвийского университета. E-mail: malova_71@mail.ru

Борбунюк Валентина, кандидат филологических наук, доцент кафеАры украиноведения. Харьковская государственная академия дизайна и искусств. E-mail: 0969255100v@gmail.com

Вершинина Наталья, Аоктор филологических наук, профессор кафедры митературы Псковского госуАарственного университета. E-mail: nati_85@inbox.ru

Горицкая ОАьга, кандидат филологических наук, доцент, Минский государственный мингвистический университет. E-mail: goritskaya@gmail. com

Емемьяненков Виталий, магистр, аспирант Аюблинского университета Марии Кюри-Скмодовской в Аюблине. E-mail: ballet2008@mail.ru

Житенев Алексанар, доктор фимологических наук, доцент кафеАры гуманитарных наук и искусств Воронежского госуАарственного университета. E-mail: superbia@mail.ru

Круповича Эмина, докторант, Институт восточноевропейских исслеАований фимософского факультета Карлова Университета (Прага, Чехия). E-mail: elinakrupovica@inbox.lv

Михаменко Наталья, кандиАат филологических наук, старший научный сотрудник ОтАела новейшей русской митературы и митературы Русского зарубежья Института мировой митературы им. А.М. Горького РАН. E-mail: tinril@list.ru

Народовска Ивета, доктор филологических наук, доцент и исследователь Отделения русистики и славистики факультета гуманитарных наук Аатвийского университета. E-mail: inaro@lanet.lv 
Поберезкина Помина, кандидат фимологических наук, независимый исследователь, Киев, Украина. E-mail: ppoberezkina@gmail.com

Пашко Оксана, кандиАат фимологических наук, старший преподаватель Национального университета «Киево-Могимянская академия» (Украина, Киев).E-mail: oksana_pashko@outlook.com

Савчук Татьяна, кандидат филологических наук, доцент кафедры прикмадной мингвистики филомогического факультета Беморусского государственного университета. E-mail: tatyana.s77@list.ru

Спроге Аюдмима, Аоктор фимологии, профессор ОтАеления русистики и славистики факультета гуманитарных наук Аатвийского университета. E-mail: 1s@latnet.lv

Тернова Татьяна, доктор филологических наук, Воронежский государственный университет. E-mail: tternova-1@mail.ru

Фролова Анна, кандидат филологических наук, Воронежский государственный университет. E-mail: frolova-anna2008@yandex.ru

Хазанова Маргарита, канА. филологических наук, доцент Института филологии и истории Российского государственного гуманитарного университета. E-mail: margaritakhazanova@yandex.ru

Хорева $\Lambda$ ариса, кандидат филологических наук, доцент кафеАры романской филологии, Российский государственный гуманитарный университет. E-mail: novella2000@mail.ru

Шром Наталья, Аоктор филологии, ассоциированный профессор Отделения русистики и славистики факультета гуманитарных наук Аатвийского университета. E-mail: natalia.shrom@gmail.com

Шевцова Алеся, заведующая кафеАрой романо-германской фимологии Могимевского государственного университета имени А.А. Кулешова, кандидат фимологических наук, Аоцент (Республика Беларусь). E-mail: alice_shev@mail.ru 
